\author{
UNIVERSIDADE DE SÃO PAULO \\ ESCOLA DE COMUNICAÇÕES E ARTES
}

CELSO LUIZ DE ARAUJO CINTRA

\title{
A musicologia comparada de Alain Daniélou: contribuições para um diálogo musical
}


CELSO LUIZ DE ARAUJO CINTRA

\section{A musicologia comparada de Alain Daniélou: contribuições para um diálogo musical}

Tese de Doutorado apresentada ao Programa de Pós-Graduação em Música da Escola de Comunicações e Artes da Universidade de São Paulo como parte dos requisitos para a obtenção do grau de Doutor em Música.

Área de Concentração: Musicologia.

Linha de Pesquisa: História, Estilo e Recepção.

Orientadora: Prof. a Dr. a Flávia Camargo Toni.

São Paulo

2013

Versão Corrigida 
Autorizo a reprodução e divulgação total ou parcial deste trabalho, por qualquer meio convencional ou eletrônico, para fins de estudo e pesquisa, desde que citada a fonte.

Catalogação na Publicação

Serviço de Biblioteca e Documentação

Escola de Comunicações e Artes da Universidade de São Paulo Dados fornecidos pelo(a) autor(a)

Cintra, Celso Luiz de Araujo

A musicologia comparada de Alain Daniélou: contribuições para um diálogo musical / Celso Luiz de Araujo Cintra. -São Paulo: C. Cintra, 2013.

207 p.: il.

Tese (Doutorado) - Programa de Pós-Graduação em Música Escola de Comunicações e Artes / Universidade de São Paulo. Orientadora: Flávia Camargo Toni

Bibliografia

1. Alain Daniélou 2. Música Sagrada 3. Filosofia da Música 4. Teoria da Música 5. Cognição Musical I. Toni, Flávia Camargo II. Título.

CDD 21.ed. - 780 
CINTRA, Celso Luiz de Araujo. A musicologia comparada de Alain Daniélou: contribuições para um diálogo musical. Tese de Doutorado apresentada ao Programa de PósGraduação em Música da Escola de Comunicações e Artes da Universidade de São Paulo como parte dos requisitos para a obtenção do grau de Doutor em Música. Versão Corrigida.

Aprovado em: 10 de abril de 2013

Banca Examinadora

Prof. ${ }^{a}$ Dr. ${ }^{a}$ Flávia Camargo Toni (Orientadora) Instituição: ECA - USP

Julgamento:

Assinatura:

Prof. Dr. Marcos Fernandes Pupo Nogueira Instituição: UNESP

Julgamento:

Assinatura:

Prof. Dr. Paulo José de Siqueira Tiné Instituição: UNICAMP

Julgamento: Assinatura:

Prof. Dr Paulo de Tarso Camargo Cambraia Salles Instituição: ECA - USP

Julgamento: Assinatura:

Prof. Dr. Mario Rodrigues Videira Junior Instituição: ECA - USP

Julgamento: Assinatura: 
Para Mari

(e Luigi) 


\section{AGRADECIMENTOS}

À Prof. ${ }^{\text {a }}$ Dr. ${ }^{\text {a }}$ Flávia Toni pela orientação precisa, carinhosa e sempre disponível;

À minha esposa Marilaine, por compartilhar comigo os melhores momentos e me confortar nos difíceis, pela paciência, pela serenidade e pelo Luigi;

A minha mãe Aldagisa (dona Dida), que me ensinou a amar os estudos;

À minha sogra dona Olga, pela paciência e carinho;

Aos amigos Eduardo e Larissa, pelas conversas sempre renovadoras;

Aos amigos Edilson de Lima e Milton Castelli pela força;

Ao Prof. Dr. Paulo Tiné e ao Prof. Dr. Mário Videira pelos comentários e pelas sugestões feitas na qualificação;

Ao Prof. Dr. Régis Duprat, que me apoiou no início desta pesquisa;

Aos companheiros do Núcleo de Música e Tecnologia - NUMUT e do Grupo Música Aberta da UFU - MAMUT da Universidade Federal de Uberlândia - UFU: André Campos, Carlos Menezes Jr., Cesar Traldi, Daniel Barreiro (e ao ex-tudo-isso Alexandre Zamith);

Aos professores e especialmente aos coordenadores do Curso de Música da UFU durante o período de gestação desta tese: Peggy Louise Bruno Storti e Cesar Adriano Traldi, pela compreensão e paciência com o doutorando. 
Só a beleza musical é a meta do compositor.

Eduard Hanslick

(HANSLICK, 2011, p. 78)

O real propósito da construção musical não é a beleza, mas a inteligibilidade.

Arnold Schoenberg

(SCHOENBERG, 1991, p. 51n)

Mais gratificante do que a busca de formas prévias no moderno é a reflexão sobre os pontos de partida $e$ os desenvolvimentos interrompidos, que foram deixados de lado pela história que até nós conduz. E descobrir no esquecido o que poderia ser útil ao presente...

Carl Dahlhaus

(DAHLHAUS, 2003, p. 140)

Kepler foi um dos últimos homens medievais. Se sua visão de ciência tivesse triunfado, é possível que não tivéssemos produzido as maravilhas e os horrores tecnológicos de hoje. Em vez disso, os cientistas seriam místicos contemplativos, andando em companhia de teólogos e músicos. Isso não aconteceu - não sei se feliz ou infelizmente...

Rubem Alves

(ALVES, 2000, p. 81)

A ciência moderna não é a única explicação possivel da realidade e não há sequer qualquer razão científica para a considerar melhor que as explicações alternativas da metafisica, da astrologia, da religião, da arte ou da poesia.

Boaventura de Souza Santos

(SANTOS, 2009, p. 83) 


\section{Resumo}

CINTRA, Celso Luiz de Araujo. A musicologia comparada de Alain Daniélou: contribuições para um diálogo musical. 2013. 207 f. Tese (Doutorado) - Escola de Comunicações e Artes, Universidade de São Paulo, São Paulo, 2013. Versão corrigida.

A tese que aqui apresentamos tem como objetivo geral estender a contribuição dos estudos de Daniélou para os campos da Filosofia da Música, Teoria Musical e da Cognição Musical, indo além do campo da Etnomusicologia dentro do qual o trabalho de Daniélou é comumente classificado; e seu objetivo específico é compreender sua contribuição para o entendimento da música em nossos dias, tanto no que se refere à sua recepção quanto às possibilidades que abre aos seus aspectos criativos. Sendo coerentes com o sistema de pensamento indiano de Alain Daniélou, e com sua afirmação da incognoscibilidade da realidade última e da falsidade da verdade tomada como dogma, analisamos seus estudos e pesquisas como interpretações ou redescrições possíveis do fenômeno musical, para isso nos baseamos na aproximação feita por Gadamer entre Teoria e Filosofia e na proposta de Rorty de que novas redescrições do objeto contribuem para ampliar o seu conhecimento, além disso concordamos com o que Kuhn aponta a respeito dos paradigmas científicos, e que Vattimo atribui especialmente às artes: a persuasão e convencimento retóricos têm um papel preponderante na consolidação de um paradigma, seja ele artístico ou científico. Entendemos as acepções musicais de Daniélou como próximas à de autores como Titus Burckhardt e sua proposição de Arte Sagrada, bem como de Joscelyn Godwin e a Música Especulativa. Analisam-se também os estudos e pesquisas de Daniélou mais como uma proposição, uma contribuição para o desenvolvimento de uma nova possibilidade criativa no domínio musical, do que uma sistematização de uma música já existente. Como resultado, a aproximação do trabalho de Daniélou permite a possibilidade de delimitação e comparação dos grupos de termos Música Especulativa e Especulação Musical; Música Sagrada e Sacralização da Música; Doutrina do Ethos, Teoria dos Afetos, e Expressão dos Sentimentos; a simbologia envolvida na metafísica musical proposta por Daniélou e a abordagem de sua Escala Universal dos Sons que nos permite delimitar os termos Tônica e Fundamental. Por fim propõe-se uma interpretação teóricofilosófica dirigida à poética da criação musical, considerando possibilidades abertas por sua escala como uma espécie diferente do relativismo do sistema do Temperamento Igual, um perspectivismo, campo fértil para a criação.

Palavras-chave: Alain Daniélou, Música Sagrada, Filosofia da Música, Teoria Musical, Cognição Musical. 


\begin{abstract}
CINTRA, Celso Luiz de Araujo. The Alain Daniélou's comparative musicology: contributions to a musical dialogue. 2013. 207 f. Tese (Doutorado) - Escola de Comunicações e Artes, Universidade de São Paulo, São Paulo, 2013. Corrected version.
\end{abstract}

This thesis aims to extend the contribution of Daniélou's studies for the fields of Philosophy of Music, Music Theory and Musical Cognition, going beyond the field of Ethnomusicology within which his work is commonly classified, and to understand its contribution to the understanding of music today, both with regard to its reception and to the possibilities that its creative aspects opens. Being consistent with the system of Indian thought of Alain Daniélou, and its affirmation of the unknowability of ultimate reality and falsehood of the truth taken as dogma, we analyze their studies and researches as possible redescriptions or interpretations of the musical phenomenon, for this we based on the approach made by Gadamer between Theory and Philosophy and Rorty's propose that new object redescriptions contribute to broaden your knowledge, beyond this, we agree with Kuhn points about the scientific paradigms, and Vattimo attaches especially to the arts: persuasion and rhetorical conviction have a leading role in the consolidation of a paradigm, be it artistic or scientific. We understand the musical descriptions of Daniélou as close to the authors like Titus Burckhardt and his proposition of Sacred Art as well as Joscelyn Godwin and the Speculative Music. It also analyzes the studies and the surveys of Daniélou more like a proposition, a contribution to the development of a new creative possibility in the field of music, than a systematization of an existing music. As a result, the approach of the Daniélou's work allows the possibility of defining and comparing the groups and terms Speculative Music and Musical Speculation; Sacred Music and Sacralization of Music; Doctrine of Ethos, Theory of Affections, and Expression of Feelings; the symbolism involved in musical metaphysical approach proposed by Daniélou and his Universal Scale of the Sounds allows us to define the terms Tonic and Fundamental or Root. Finally we propose a theoretical-philosophical interpretation addressed to the poetics of musical creation considering the possibilities opened up by its scale as a different kind of relativism of the Equal Temperament System, perspectivism, fertile ground for the creation.

Keywords: Alain Daniélou, Sacred Music, Philosophy of Music, Music Theory, Musical Cognition. 


\section{SUMÁRIO}

INTRODUÇ̃̃̃O

PARTE 1 - EXPLICAÇÕES: ENTENDENDO ALAIN DANIÉLOU ............................. 13

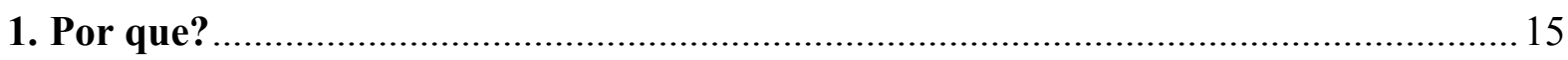

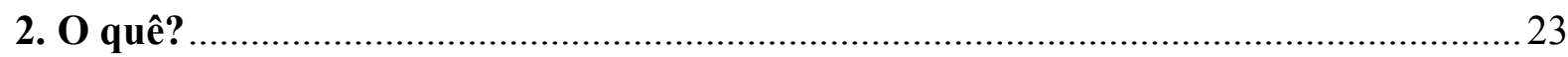

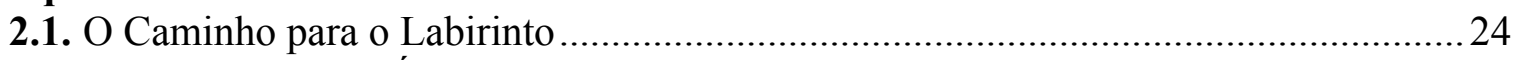

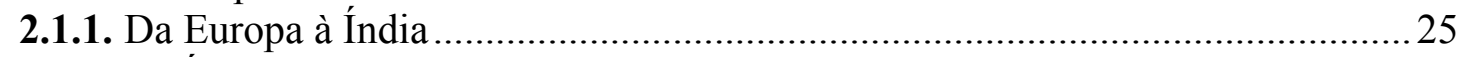

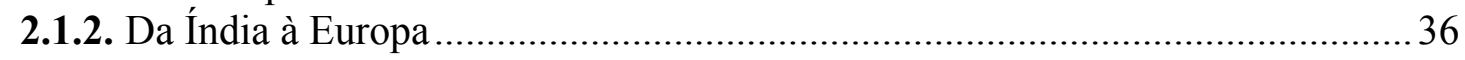

2.2. Música e o Poder do Som (Tratado de Musicologia Comparada).............................. 41

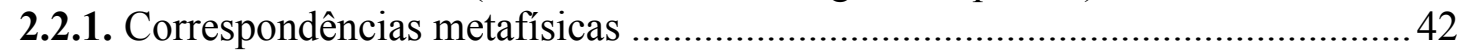

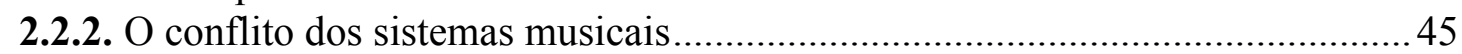

2.2.3. A medida dos intervalos e dos sons harmônicos ................................................ 48

2.2.4. O ciclo de quintas: a teoria musical dos chineses...........................................51

2.2.5. Relações com uma tônica: a música modal da Índia ......................................... 54

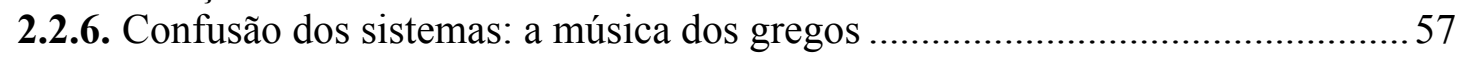

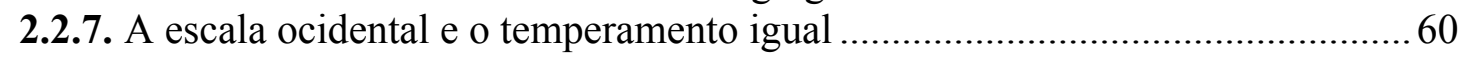

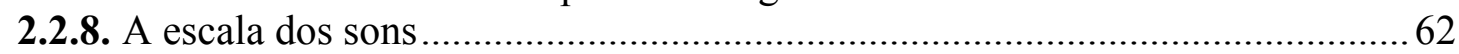

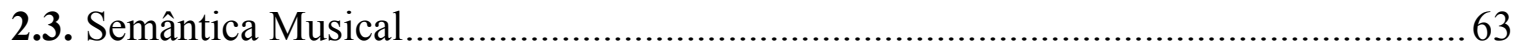

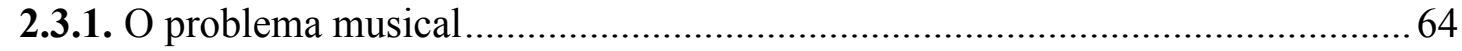

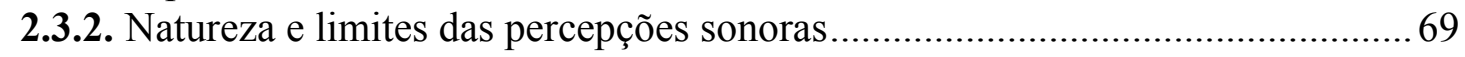

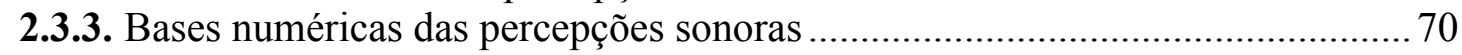

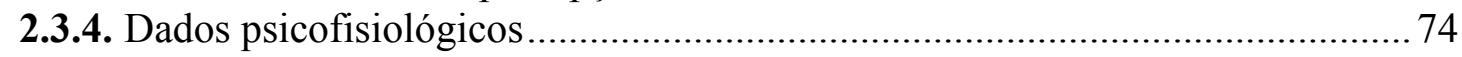

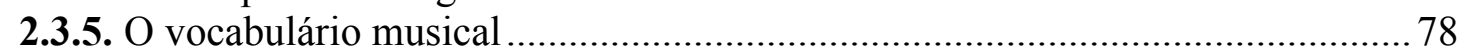

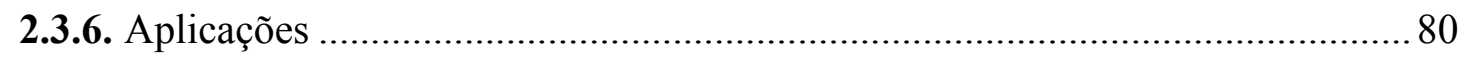

2.4. Música e Metafísica em Alain Daniélou ................................................................. 81

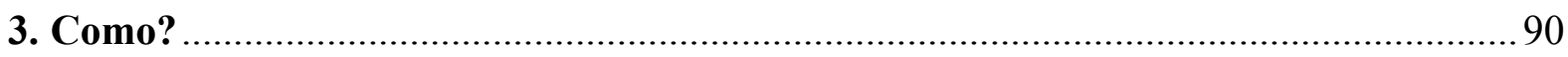

PARTE 2 - IMPLICAÇÕES: ESTENDENDO ALAIN DANIÉLOU ........................... 102

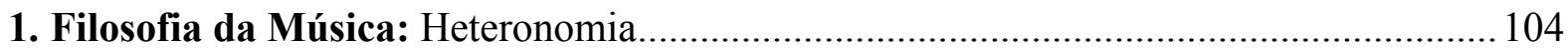

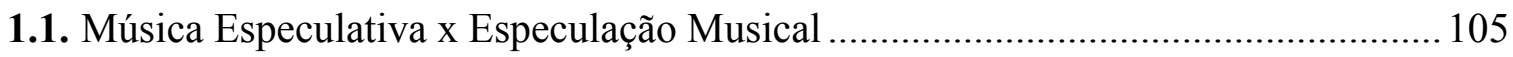

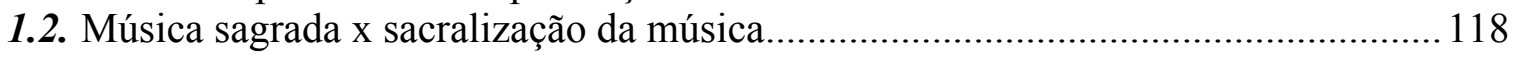

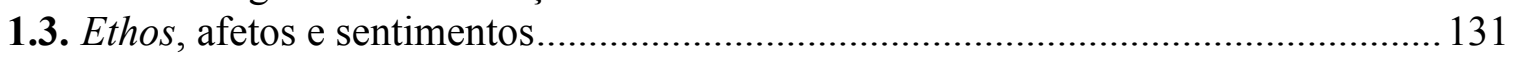

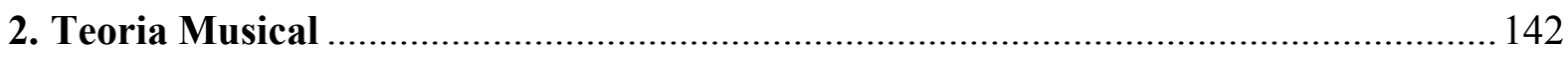

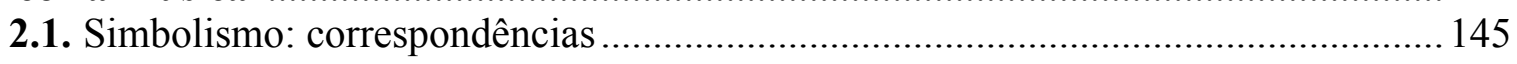

2.2. Matemática: a Escala Universal dos Sons e sua relação com a série harmônica ..... 156

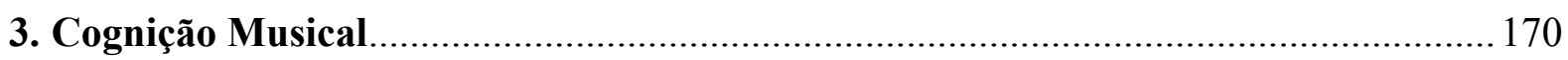

PARTE 3 - CONCLUSÕES: APREENDENDO ALAIN DANIÉLOU ........................ 179

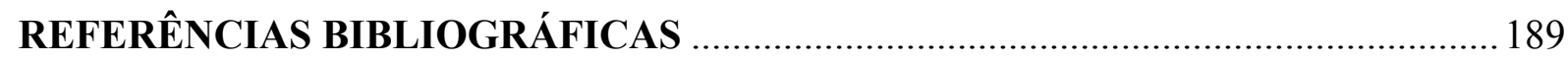




\section{INTRODUÇÃO}

A música é, assim, acima de tudo um método de realização interior em um nível onde os diferentes estados de ser não são diferenciados, onde nos tornamos conscientes de que forma e matéria, emoção e intelecto, prazer e alegria são apenas expressões dos mesmos códigos manifestadas em vários níveis, com o resultado que o mesmo padrão musical pode ser expresso por uma equação, um estado emocional, uma experiência espiritual ou uma evocação que, se intensa $o$ bastante, pode tornar-se criação $[\ldots]^{1}$ (DANIÉLOU, 2008a, p. 89)

Embora tenha escrito sobre vários assuntos, da religião à filosofia, da sociologia à história passando pela arte e literatura, consideramos que a maior contribuição de Daniélou está no campo da música, com textos e livros não só sobre música africana, chinesa, do Laos e sobre a música clássica da Índia, mas também sobre a música clássica ocidental.

Trocou correspondências com René Guénon ${ }^{2}$, editadas sob o título de La corrispondenza fra Alain Daniélou e René Guénon: 1947 - 1950 por Alessandro Grossato em 2002 sobre aspectos filosóficos e religiosos do Hinduísmo Shivaísta e esteve envolvido com o movimento de independência da Índia. Além disso conheceu e conviveu com figuras como Jean Cocteau, Serge Diaghilev, Stravinsky e posteriormente com outros como Paul Valéry, André Gide e Benedetto Croce.

Artistas de diversos países como o violinista Yehudi Menuhin e o sitarista Ravi Shankar consideram seu trabalho "decisivo para o reconhecimento da música clássica da Índia, não só como música folclórica como tinha sido classificada até então, mas como uma grande e magistral arte no mesmo nível da música ocidental” (CLOAREC, 2003, p. 209).

Por tais motivos, destacando também sua característica polimática, consideramos importante e necessário o estudo de sua obra não só no que tange ao estudo da música não europeia, mas também no muito que tais estudos podem contribuir para o entendimento da própria música ocidental, considerando a limitadíssima publicação de suas obras em terras brasileiras $^{3}$ ou mesmo em língua portuguesa. Desta maneira, esta tese procura contribuir para

\footnotetext{
${ }^{1}$ Music is thus above all a method of inner realization on a level where the different states of being are not differentiated, where we become aware that form and matter, emotion and intellect, pleasure and joy are but expressions of the same codes manifested on various levels, with the result that the same musical pattern can be expressed by an equation, an emotional state, a spiritual experience, or an evocation, which, if intense enough, can become creation [...]

${ }^{2}$ René Guénon (1886-1961) foi conhecido como porta-voz, junto com Frithjof Schuon, da Filosofia Perene, que defendia a unidade transcendente de todas as religiões.

${ }^{3}$ O único livro de Daniélou publicado no Brasil não é sobre música, trata-se de Shiva e Dioniso: a religião da natureza e do Eros (DANIÉLOU, 1989). É também sua única obra publicada em português.
} 
preencher um pouco desta lacuna em nosso país.

Aventuramo-nos no estudo de suas obras a fim de entendê-las não só em seu sentido etnomusicológico, de pesquisa da música de outras culturas, mas também no que elas podem propor, inspirar e lançar luzes que auxilie no entendimento da própria música ocidental, em seu sentido estético-filosófico, teórico e cognitivo, possibilitando o entendimento e interpretação daquilo que na música ocidental muitas vezes é tratado como lenda ou mito, quais sejam, seus efeitos psicológicos e fisiológicos.

Buscamos capturar nos escritos de Daniélou as possibilidades de diálogo entre a música do oriente e a música ocidental, principalmente no que diz respeito ao pensamento musical grego do qual nos consideramos herdeiros, de forma que este diálogo lance luzes para o entendimento de como se desenvolveu o sistema musical ocidental, como se deu a opção, ou falta dela, pelo temperamento, segundo alguns teóricos, o resultado do "exercício livre, especulativo e sem barreiras de procedimentos composicionais fundamentais na música, quais sejam: o princípio da transposição e o da modulação" (MENEZES, 2003, p. 243 destaques do autor), mas considerado por Daniélou como Agressão Harmônica ${ }^{4}$, e de como estas características musicais se relacionam e são interpretadas dentro de um contexto mais amplo que inclua a filosofia e não apenas elementos técnico-musicais.

É inegável a contribuição de Daniélou para que o Ocidente tivesse acesso e conhecimento das músicas não ocidentais. Também destacamos sua contribuição para o campo de estudos que ajudou a construir, a Musicologia Comparada que posteriormente adotou o nome de Etnomusicologia. Porém, o desenvolvimento deste campo, principalmente após Alan P. Merrian e seu Anthropology of Music (1964), deu-se de maneira que o aspecto antropológico passa a ser um dado incontornável da pesquisa etnomusicológica. Por tal motivo, focamos nosso trabalho e concentramos nosso estudo sobre a obra musical de Daniélou em três áreas: Filosofia da Música, Teoria da Música e Cognição Musical.

Para que possamos nos aproximar da proposta de Alain Daniélou - afrouxando as influências da forma ocidental de apreensão musical - evitamos, na medida do possível, o uso de exemplos em notação musical tradicional, para que, mesmo correndo o risco de dificultar um pouco o entendimento devido a aparente aridez da representação matemática, nos obrigássemos a pensar de outra maneira. Porém, mantivemos os nomes das notas ocidentais, tanto o latino derivado do Hino a São João (Do, Re, Mi Fá, Sol, La, Si), quanto o anglo-saxão por letras $(\mathrm{C}, \mathrm{D}, \mathrm{E}, \mathrm{F}, \mathrm{G}, \mathrm{A}, \mathrm{B})$, acrescentando, quando se tratava de indicação do próprio

\footnotetext{
${ }^{4}$ Título de um de seus textos: L'Agression harmonique (DANIÉLOU, 2005b).
} 
Daniélou, os nomes indianos correspondentes ( $\mathrm{Sa}, \mathrm{Re} \mathrm{Ga}, \mathrm{Ma}, \mathrm{Pa}, \mathrm{Dha}, \mathrm{Ni})$

Partindo do princípio de que determinadas informações precisam ser manuseadas e analisadas de maneira que se possa extrair e construir a partir delas novas ideias, e que ao manusearmos estas informações podemos dobrá-las, desdobrá-las ou simplesmente observálas em sua forma original, utilizaremos nesta tese como fio condutor o verbo latino plicare, que significa dobrar.

Esperamos poder então, ao pensarmos no trabalho de Daniélou, entender como se dá seus desdobramentos e como, ao colocá-lo em diálogo com outras informações, ele se dobra possibilitando aproximar informações que estariam aparentemente distantes. Utilizando uma pequena licença poética, acrescentamos ao verbo plicare um prefixo que o transforma numa palavra conhecida de nossa língua, que passa assim a dar título a duas das partes, e que ao mesmo tempo caracteriza a atividade a que será submetida a sua obra nesta parte.

Na Parte 1 - Explicações: entendendo Alain Daniélou, procuraremos "dobrar para fora" ou "desdobrar", tornar exterior o pensamento de Daniélou, explicar aquilo que justifica sua obra para que se possa entendê-la. Ela se divide em três capítulos em forma de perguntas:

\section{Por que?; 2. O quê? e 3. Como?.}

Na Parte 2 - Implicações: estendendo Alain Daniélou, faremos o inverso, "dobrar para dentro" porém acrescentando informações das áreas a que serão submetidos seus estudos, estendendo portanto, o horizonte de entendimento da sua obra, para que ao dobrá-las seja possível ver também "através", encontrando conexões entre coisas aparentemente desconectadas. Também a dividiremos em três capítulos: 1. Filosofia da música: Heteronomia; 2. Teoria da música e 3. Cognição musical.

Na Parte 3 - CONCLUSÕES: Apreendendo Alain Daniélou, teceremos nossas considerações finais, retomando elementos da Parte 1 e da Parte 2 para colocá-los em diálogo. Também abordaremos brevemente o trabalho de dois compositores que foram leitores de Daniélou - La Monte Young e Ben Johnston - e que se deixaram influenciar pelos seus escritos. Por fim, sugerimos uma interpretação da escala proposta no trabalho de Daniélou como uma possibilidade de desenvolvimento musical diferente daquela proporcionada pelo sistema do temperamento igual. 
PARTE 1

\section{EXPLICAÇÕES:}

ENTENDENDO ALAIN DANIÉLOU 
Como dito na INTRODUÇÃO, começa aqui o primeiro desenvolvimento do verbo latino plicare, que significa dobrar, no contexto desta tese sobre Alain Daniélou. Ao acrescentar o prefixo ex coloca-se como objetivo a ideia de "dobrar para fora" ou "desdobrar", trazer à tona de maneira mais clara e imparcial possível, porém já estabelecendo um breve diálogo com outros autores, aquilo que deixou Daniélou em seus escritos sobre música. Tais diálogos serão ampliados na Parte 2 - Implicações: estendendo Daniélou. O foco desta primeira parte é sobre a justificativa - no capítulo 1. Por que?; objeto e objetivos - no capítulo 2. O quê?; e referências (e inferências) metodológicas utilizadas nesta tese - no capítulo 3. Como?. 


\title{
1. Por que?
}

\begin{abstract}
A "técnica", ou tratamento de um problema começa com sua primeira expressão como pergunta. O modo pelo qual uma pergunta é proposta limita e assenta os meios pelos quais qualquer resposta a ela - certa ou errada possa ser dada. (LANGER, 1971, p. 16)
\end{abstract}

A citação de Susanne Langer na epígrafe desta seção diz respeito à pergunta que se faz para o desenvolvimento de uma pesquisa, de como ela já é limitada pela sua própria formulação, e de como essa formulação é limitadora de sua resposta.

Embora uma pesquisa mereça seus méritos principalmente por aquilo que ela possa trazer de significativo para sua área, ampliando seu entendimento atual e jogando novas luzes sobre seus aspectos históricos, ela também traz em seu bojo várias outras histórias que mesmo não tratando de modo direto seu objeto de estudo, contribuem para esboçar um entendimento do alcance que esse objeto possui.

Começo então este texto com outra pergunta, que não é ainda a nossa pergunta de pesquisa mas que, levando em consideração as diversas histórias que acompanham qualquer investigação, referidas acima, terá como resposta um dado significativo para esta pesquisa, podendo ampliar o entendimento desta apesar do dado limitador que, segundo Langer, a formulação da pergunta de pesquisa propriamente dita dará ao desenrolar de suas possíveis respostas.

Por que Alain Daniélou?

Esta singela pergunta não foi feita originalmente por mim, mas foi feita quando de minha entrevista para ingresso no programa de doutorado e é recorrente a cada nova conversa com professores, colegas pesquisadores e alunos.

Sempre me pareceu óbvio que uma pesquisa deveria ser feita sobre Alain Daniélou, e como não encontrei, ao menos em português, alguém que a tivesse empreendido, resolvi que eu mesmo a faria. No entanto, uma justificativa como esta seria como responder à pergunta com outra, de caráter retórico: Por que não Alain Daniélou?

Como observa Langer (1971, p. 16), esta seria uma resposta só na aparência, pois, além de ser também uma pergunta, rejeitaria a própria questão. Coube então fazer esta pergunta a mim mesmo, para que ela passasse a fazer sentido quando vinda de outras pessoas. Notei que para que esta pergunta começasse a ter a necessidade de ser respondida, não bastaria uma simples resposta que, por si só, de maneira impessoal, desse a dimensão da 
importância do trabalho de Daniélou. Seria necessário partir de algo tão singelo quanto a própria pergunta: contar a mim mesmo, quase como se fosse um conto, como se deu meu interesse por esta figura singular que é Alain Daniélou.

A primeira vez que soube de Alain Daniélou foi por meio do livro $O$ som e o sentido, de José Miguel Wisnik (1989), durante minha graduação no início da década de 1990, quando estudava Composição e Regência na UNESP. Foram duas referências retiradas do livro Sémantique musicale: essai de psycho-physiologie auditive de Daniélou.

Ao tratar da questão rítmica na música, Wisnik cita Daniélou literalmente afirmando que "o ritmo alfa parece ser de fato a base que determina o valor do tempo relativo e

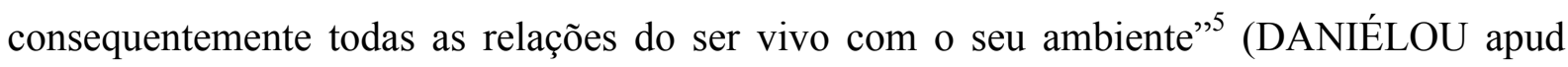
WISNIK, 1989, p. 20). Mais adiante, ao se referir à progressiva adoção do temperamento igual na música ocidental, novamente Wisnik se reporta a Daniélou, porém numa paráfrase:

\begin{abstract}
Alain Daniélou, musicólogo engajado na defesa da música modal, que ele considera "verdadeira" linguagem do som, em oposição à música tonal, sustenta, possivelmente com razão, que a escuta de uma sonata qualquer ao piano demanda grande esforço não-consciente do ouvinte, implicando um grau de fadiga subliminar que a música indiana, por exemplo, desconheceria. (WISNIK, 1989, p. 85 aspas do autor)
\end{abstract}

O que me chamou atenção nestas referências foi o fato de que se tratava de uma visão a respeito da música, e da atividade cerebral envolvida em sua escuta, que diferia muito daquela do senso comum ao qual estava acostumado a lidar, quase sempre baseada na emoção proporcionada pela música ou no mero juízo de gosto. Tratava-se de uma crítica ao Temperamento Igual utilizado nos instrumentos de teclado ou de trastes, e nesse caso específico, no piano. Eu nem sequer sabia que existiria, no ocidente, algum tipo de afinação diferente desta, a não ser no trabalho de alguns compositores contemporâneos considerados, no contexto do ensino daquela época, como experimentais ou excêntricos, ainda mais a hipótese de que tal afinação poderia causar algum tipo de fadiga mental!

Embora os estudos sobre cognição musical já estivessem se desenvolvendo há pelo menos quarenta anos, a escassez de literatura em língua portuguesa, que até hoje se faz sentir; aliada a minha pouca experiência como aluno universitário e pesquisador; conjugada com o pouco conhecimento de outras línguas que não o português e um precário inglês; sem contar as dificuldades de preços e prazos para importação de livros, lembrando que nesta época não

\footnotetext{
${ }^{5}$ No original: Le rythme alpha semble être en fait la base qui détermine la valeur du temps relatif et par conséquent tous les rapports de l'être vivant avec son environnement (DANIÉLOU, 1993, p. 33).
} 
existia as facilidades de compras via world wide web, naturalmente me impediram de desenvolver algum tipo de aprofundamento sobre Alain Daniélou. Porém tal encontro com este pequeno fragmento ficou guardado no inconsciente, esperando períodos propícios para emergir de acordo com as circunstâncias.

Por volta da virada do século XX para o XXI, quando iniciei meus estudos de tabla e música indiana, com a cantora Meeta Ravindra e seu filho Sagar que a acompanhava à tabla, além de participar como percussionista em grupos de música clássica turca, me deparei com os livros Sémantique musicale e Traité de musicologie comparée de Alain Daniélou na casa de um de meus colegas músicos, porém o ciúme do livro por parte de meu colega e minha inabilidade com o idioma francês, além do rumo - baseado no acaso na música contemporânea - que tomou minha dissertação de mestrado, mais uma vez me afastou desse autor.

Somente em 2006 é que tive acesso ao livro Music and the power of sound, uma versão americana do Traité de musicologie comparée, e então pude ter contato efetivo e direto com a obra de Alain Daniélou, que em seu desenrolar trouxe-me ao desenvolvimento da tese que aqui apresento.

Pequeno parêntesis: curiosamente, só encontrei outro autor brasileiro que o citasse, além de Wisnik, muito tempo depois, durante a exploração bibliográfica para a confecção desta tese. O compositor Jorge Antunes cita também o Sémantique Musicale no artigo $O$ silêncio (1999):

\begin{abstract}
Nosso aparelho mental funciona como uma máquina de calcular que - tão logo os dados de um problema lhe são fornecidos - continua a funcionar até a descoberta de uma solução aceitável. Nós ignoramos completamente um grande número de elementos sonoros quando eles não se conectam em um conjunto inteligível. Entretanto, nós podemos gravar sons na mente, mesmo muito longos, emitidos em um contexto sonoro muito mais intenso, desde que existam agenciamentos lógicos entre eles. ... este um [sic] dos motivos pelos quais somos capazes, por exemplo, de acompanhar uma conversa em um lugar muito barulhento ${ }^{6}$. (DANIÉLOU apud ANTUNES, 1999)
\end{abstract}

Embora Antunes esteja empregando a citação de Daniélou para justificar outro aspecto em seu artigo sobre o silêncio, o trecho por ele citado faz referência ao chamado efeito festa

\footnotetext{
${ }^{6}$ No original: Notre appareil mental fonctionne comme une machine à calculer qui, lorsque les données d'un problème lui sont fournies - ici la signification de rapports de sons-, continue à fonctionner jusqu'à la découverte d'une solution acceptable. Nous ignorons complètement un grand nombre d'éléments sonores parce qu'ils ne sont pas connectés dans un ensemble intelligible. Par contre, nous pouvons enregistrer des sons, même très ténus, émis dans un contexte sonore beaucoup plus intense parce qu'il existe entre eux des liens logiques. C'est ainsi, par exemple, que nous sommes capables de suivre une conversation dans un endroit bruyant (DANIÉLOU, 1967, p. 15).
} 
(cocktail-party effect), termo usado na acústica para definir a capacidade que temos de nos concentrar "na fala de alguém em um ambiente no qual muitas pessoas estejam falando ao mesmo tempo, como num bar ou numa festa" (MENEZES, 2003, p. 225).

Contudo, esta frase, citada por Antunes, no texto de Daniélou serve para justificar sua afirmação a respeito de nossa capacidade de processamento mental dos sons que através dos ouvidos chegam ao cérebro. Ela diz respeito principalmente à linguagem falada, situação um pouco diferente da música, mas que possui em comum com esta algum tipo de conexão lógica entre os sons - como destacado por Daniélou na citação acima, o que tornaria possível concentrar a atenção no interlocutor ou em uma fonte sonora. Entretanto, também outros dados devem ser levados em consideração, como o interesse de quem ouve naquilo que ouve ou mesmo o interesse do ouvinte em outras conversas que estejam acontecendo à sua volta. Parênteses fechado.

As citações de Wisnik que despertaram meu interesse em Daniélou são do Sémantique Musicale. Mas, o fato de começar a leitura de Daniélou por Music and the power of sound colocou-me em contato com outros aspectos de sua obra.

Como veremos mais detalhadamente adiante, Daniélou baseia seu livro Sémantique Musicale nos estudos sobre cibernética do matemático americano Norbert Wiener. Nele Daniélou compara o cérebro a um processador, um computador que processa informações sobre relações sonoras em três linguagens simultâneas: binária, ternária e quinária; ou seja, trata-se de um livro cuja intenção é analisar os possíveis efeitos da música na consciência individual, tentando estabelecer a partir daí uma possível significação universal para o que Daniélou considera a linguagem musical.

Já no seu livro Music and the power of sound, ele trabalha com aspectos históricos e étnicos do desenvolvimento musical, concentrando sua atenção em como se estruturam formalmente três grandes sistemas - o Chinês, o Indiano e o Grego - para gerar significações musicais, que ele depois abordou em Sémantique Musicale.

Antes que este pequeno relato se torne um memorial, a resposta à pergunta: "Por que Alain Daniélou?" encontrei em minha própria formação e intenção como compositor, pois vejo que Alain Daniélou estava interessado naquilo que seus estudos poderiam trazer para a criação musical, como poderia influenciar na criação de uma música que levasse em consideração dados além dos elementos estruturadores vindos da tradição tonal, ou dependentes do puro gosto ou emoção. E neste sentido podemos fazer um paralelo com a geração de Cage e Boulez que queriam fazer tabula rasa da música pra começar algo novo. Contudo, seu foco é outro, pois entende que "a utilização de um vocabulário musical baseado 
sobre dados psicofisiológicos precisos e sobre um melhor conhecimento do conteúdo semântico dos sons é a chave da arte musical do futuro"77 (DANIÉLOU, 1993, p. 95).

Como compositor, portanto, leio a obra de Daniélou mais como um desafio ou uma proposição poética do que como uma pesquisa científica no campo etnomusicológico, ou mesmo no campo da cognição musical. No entanto, para que seja possível entender o porquê desta minha leitura, é necessário fazer justamente uma desleitura ou uma desidentificação, conseguir ver por outros olhos, que não o do compositor, seu itinerário como músico e pesquisador. E aqui já encaminho meu texto para outras perguntas que serão de fato as perguntas que direcionarão esta pesquisa, para que se torne mais clara sua justificativa.

Retomando Langer, é preciso estar consciente que “em nossas perguntas encontram-se nossos princípios de análise, e nossas respostas podem expressar tudo o que esses princípios sejam capazes de admitir" (LANGER, 1971, p. 17 grifos da autora).

Antes de formular as perguntas começo por algumas respostas, para que então possamos descobrir as perguntas que as geraram, somente assim será possível formular novas perguntas, essas sim passíveis de trazer algo de novo para aquilo que entendemos como o estudo científico. No nosso caso, tal estudo científico é desde sempre identificado com a área das humanidades, porém sem esquecer que é da arte que falamos. E à arte mais do que explicar, cabe ser explicada; mais do que desvelar, cabe revelar e mais do que provar, cabe a ela propor.

Sendo assim, minha proposta é buscar estender os horizontes a respeito do entendimento da obra de Daniélou, procurar lê-lo em outra chave, para que novas perguntas possam ser feitas, pois

os limites do pensamento são estabelecidos menos de fora, pela plenitude ou pobreza de experiências com que a mente defronta, do que de dentro, pelo poder de concepção, pela riqueza de noções formuladoras com que a mente enfrenta as experiências. A maioria das novas descobertas são coisas subitamente vistas que sempre lá estiveram. (LANGER, 1971, p. 20)

Alain Daniélou é um novelo de lã. Porém não é um novelo contínuo e monocromático.

\footnotetext{
${ }^{7}$ L'utilisation d'un vocabulaire musical basé sur des donnés psychophysiologiques précises et sur une meilleure connaissance du contenu sémantique des sons est la clé de l'art musical de l'avenir.
} 
Nele há diversos e longos fios de variadas cores e que também mudam de cor durante o desenrolar de seu comprimento. Desenrolar este novelo sem deixá-lo embaraçar não é tão fácil quanto pode parecer num primeiro momento, ainda que respostas fáceis tenham sido produzidas a respeito de sua vida e de seu trabalho intelectual.

Escritor profícuo, pesquisou e escreveu sobre a história e mitologia da Índia, religião e filosofia hindus além de música. Morou mais de 20 anos na Índia tendo se convertido ao hinduísmo shivaísta. Por ter escrito sobre a música de diversos países orientais, principalmente a música indiana, além de ter sido responsável pela vinda ao ocidente de inúmeros artistas orientais, colaborando para que estes artistas voltassem a ser reconhecidos por sua arte em seus próprios países, onde já estavam praticamente esquecidos, Alain Daniélou é considerado por muitos como etnomusicólogo, porém nesta tese procuraremos demonstrar que, embora seus estudos possam ser úteis para a etnomusicologia, e de fato o são, sua longevidade parece se dar num campo em que ele é pouco explorado: as áreas da teoria e cognição musicais, se estendendo pelo campo da estética e filosofia da música.

Esta mudança de referência quanto ao seu trabalho, pode nos trazer importantes contribuições para o entendimento de nossa própria música, uma vez que Daniélou, tendo se tornado um músico dedicado à vīna ${ }^{8}$ e à pesquisa de tratados antigos de música indiana, sempre analisa a música ocidental tomando como base a música indiana, fazendo uma espécie de Etnomusicologia da música ocidental, numa época em que esta ainda se chamava Musicologia Comparada, não por acaso o nome de um de seus livros sobre música. Além disso, baseou seus estudos sobre semântica musical nos estudos de Wiener sobre Cibernética, o que o aproxima dos estudos sobre cognição musical.

É necessário nesta empreitada, de analisar o trabalho de Daniélou sob outra ótica e referencial, entender aquilo que podemos considerar como seu sistema musical, embrenhar-se em seus conceitos e definições, mergulhar em seu pensamento não como quem vê por meio de seus olhos ou ouve por seus ouvidos, mas sim emprestar nosso cérebro (DURKHEIM apud GHIRALDELLI JUNIOR, 2013) para que seu pensamento possa de novo reviver e dialogar com toda a nossa informação, para que daí possamos valorizar aquilo que de fato é ainda relevante e consigamos enxergar, naquilo que não mais nos afeta ou não nos interessa nesse momento do desenvolvimento científico da pesquisa musical, as possíveis falhas e desvios de rota em seus estudos ou nas interpretações que deles fizeram os pesquisadores, e como tais estudos poderiam tornar-se relevantes agora, ou num futuro próximo.

\footnotetext{
${ }^{8}$ Instrumento musical indiano de cordas pinçadas, semelhante ao sitar.
} 
Pesquisar sobre a obra de um pesquisador é uma tarefa interessante. Como será feita a análise? Tentando referendar todas as suas teorias, caso se tenha simpatia por este pesquisador, ou procurando refutar todas as suas afirmações, caso se note que uma ou outra destas se revelem sem fundamento? Uma pesquisa sobre uma pesquisa deve ser uma metapesquisa, algo além da pesquisa, uma pesquisa que pesquise o próprio ato de pesquisar, assim como a metalinguagem fala da própria linguagem.

No entanto, e além disso, esta pesquisa é sobre um pesquisador, um ser humano que, como tal, é um sujeito que interpreta, influenciado pelo seu tempo, espaço e pessoas com as quais conviveu, em diálogo com toda sua formação, responsável por sua bagagem intelectual, religiosa e familiar.

Portanto, entender Daniélou é entender muitas coisas por consequência de suas definições. Por exemplo, para saber o que Daniélou define como música é necessário entender o que ele entende por música indiana; o porquê de sua opção pela teoria musical para comparar músicas de diversos países; o que ele entende por teoria musical, e então entender o que vem a ser a, ou uma, teoria musical; o que nos leva à necessidade de desvelar o que vem a ser teoria em seu sentido amplo, para daí voltar novamente àquilo que ele chama de teoria musical e daí o que ele chama de música, para então nos darmos conta de que neste processo é necessário reler todos nossos fundamentos e reinterpretá-los para que seja possível estabelecer um diálogo livre, ou ao menos mais desarmado, de preconceitos que tornam um pesquisador cego diante de evidências óbvias.

Embora este processo se dê e seja recomendado no mínimo desde Descartes, é a partir da descrição de Thomas S. Kuhn (2003) em A Estrutura das Revoluções Científicas, de 1962, sobre o desenvolvimento histórico dos paradigmas científicos, que ele pode ser visto de maneira mais interessante, pois tal processo é capaz de revelar evidências e provas dentro de um determinado paradigma. Mas a pergunta que nos move é: como estas evidências seriam vistas a partir de outro paradigma? Como estas fundamentações teóricas se comportariam se não se acreditasse nelas? Pois o primeiro passo para uma pesquisa pode começar com uma dúvida ou uma descrença numa afirmação aparentemente irrefutável.

Qual seria a interpretação necessária para que uma descrição mostrasse que determinadas evidências não se sustentam em outro ambiente? Como Vattimo (2002) aponta em seu texto escrito originalmente em 1985, cujo título é paráfrase da obra de Kuhn: $A$ Estrutura das Revoluções Artísticas, a arte é o campo por excelência para aquilo que Kuhn detectou nas mudanças de paradigmas científicos: é a persuasão e o convencimento retóricos, mais que apenas os critérios de validade e demonstração, que tornam um novo paradigma 
aceitável.

E neste caso, em que se trata de uma pesquisa sobre arte, mais especificamente sobre música, ainda mais sobre um pesquisador que também foi músico? Como se dá a pesquisa científica num contexto como esse em que Daniélou viveu? Um período de formação de um novo campo, que se separa da Musicologia em seu sentido mais amplo, para se afirmar com independência, ainda que se utilizando de ferramentas antropológicas e ainda ligado à música, como foi o caso da Etnomusicologia? Bastaria simplesmente interpretar as questões de Daniélou como inadequadas para o campo que ele de alguma maneira ajudou a formar e que, por não seguir as direções que este mesmo campo tomou, entendê-lo como ultrapassado?

Embora todas essas perguntas pareçam um tanto óbvias, não as são no caso de Daniélou. Como bem aponta Merrian (1969), encontram-se na Etnomusicologia tendências mais antropológicas e tendências mais musicológicas. Daniélou se encaixa nestas últimas se o entendermos dentro da Etnomusicologia. Mas, apenas o fato de estudar música indiana, comparando-a com as de outras culturas faz dele um etnomusicólogo? Ou seja, seu objeto definiria seu campo de estudos? ${ }^{9}$ Se o víssemos em outro campo sua obra faria mais sentido? Ainda assim ele seria um etnomusicólogo? Por ser um ocidental estudando música oriental, ainda que completamente convertido a esta nova cultura, adotando sua religião e filosofia e aprendendo sua música não só pelos tratados teóricos, mas também pela prática de um instrumento a ponto de se tornar um experto, sua formação inicial ainda seria forte o suficiente ao analisar esta cultura, que Daniélou abraçou tão aguerridamente? Isto tornaria sua análise, em suas entrelinhas, ainda aquela que utiliza a música ocidental como ponto de referência, ou ele consegue isenção suficiente para ver a música ocidental "de fora"?

Estas são as perguntas que movem esta tese, são suas justificativas e já delineiam seus objetivos, embora ainda não sejam sua hipótese, e acreditamos poder respondê-las.

\footnotetext{
9 "Musicologia, teoria e etnomusicologia não devem ser definidas [...] em função de seu objeto de estudo, mas em termos de suas filosofias e ideologias" (KERMAN, 1987, p. 7).
} 


\section{O quê?}

A pergunta que nomeia este capítulo tem a função de direcionar nossa atenção para o que será estudado nesta tese, seu tema, que é o trabalho musicológico de Alain Daniélou.

A forma como se pode entender esta pergunta coloca o foco de nossa atenção no objeto de estudo e, aproveitando a proximidade ortográfica entre as palavras, em seus objetivos.

O objetivo geral desta pesquisa é estender a contribuição dos estudos de Daniélou para os campos da Filosofia da Música, Teoria Musical e da Cognição Musical, indo além do campo da Etnomusicologia dentro do qual o trabalho de Daniélou é comumente classificado; e seu objetivo específico é compreender sua contribuição para o entendimento da música em nossos dias, tanto no que se refere à sua recepção quanto às possibilidades que abre aos seus aspectos criativos.

Para delimitar o objeto desta tese dentro deste tema, levando em consideração seus objetivos geral e específico, é necessário fazer uma abstração que dê conta de extrair uma unidade dentro deste trabalho musicológico empreendido por Daniélou. Para isso será feita uma incursão analítica em seus principais escritos sobre música, bem como em sua autobiografia, para que o diálogo proporcionado pelo encontro entre estas narrativas amplie o entendimento do contexto no qual suas concepções sobre música foram desenvolvidas.

A partir da análise estrutural de seus textos musicológicos, descobrindo e mergulhando em seu tempo próprio (GOLDSCHMIDT, 1963), pode-se abstrair de cada um suas respectivas hipóteses, entendendo o quanto tais hipóteses podem ser classificadas em duas vertentes: como consequências de seus estudos ou como causas para a realização de suas pesquisas. Estas hipóteses são o objeto desta tese. A unidade subjacente a estas hipóteses emergirá da análise de textos que abordem principalmente suas concepções filosóficas, que dirigem sua visão para a realização de suas pesquisas, e suas crenças religiosas - visto que a música clássica indiana à qual ele se dedicou, possui um vínculo profundo com a religião hindu bem como de dados de sua autobiografia que possam ajudar no entendimento de seu percurso intelectual.

Para isto, este capítulo foi subdividido em subcapítulos, cada um dedicado a um aspecto de sua obra. O critério inicial para a escolha das obras aqui analisadas baseia-se numa passagem de sua autobiografia, The Way to the Labyrinth (1987). Nela ele comenta sobre a 
publicação de suas obras e se refere a Pierre Bérès - um editor especialista em livros antigos afirmando: "Bérès editou alguns de meus mais difíceis trabalhos, tais como o Traité de musicologie comparée e especialmente Sémantique Musicale, que desafiam os princípios básicos de todos os sistemas musicais"10 (DANIÉLOU, 1987, p. 235-236).

Também será exposto, após a apresentação dos dois livros acima, a concepção metafísica da música em Alain Daniélou, em que utilizaremos o texto La théorie métaphysique du verbe et son application dans le langage et la musique (2007), em diálogo com $A$ arte sagrada no oriente e no ocidente de Titus Burckhardt e com a coletânea de textos publicada com o nome Sacred music its origins, powers and future (2003a) e sua versão francesa Origines et pouvoirs de la musique (2005a). Inicia-se com a autobiografia de Alain Daniélou, The way to the labyrinth.

\subsection{O Caminho para o Labirinto}

Eu me senti, de fato, como um completo estrangeiro na terra onde nasci. Pelo meu modo de pensar, sentir, viver, eu pertencia agora a outra civilização. ${ }^{11}$ (DANIÉLOU, 1987, p. 221)

A autobiografia de Alain Daniélou foi publicada originalmente em francês em 1981 com o título Le chemin du labyrinthe, e em 1987 em inglês, na edição americana traduzida por Marie-Claire Cournand como The way to the labyrinth. Este título, que em português pode ser traduzido como $O$ Caminho para o labirinto, encerra em si já uma ambiguidade, pois ao mesmo tempo em que se refere aos caminhos labirínticos que percorreu em sua vida e em suas concepções filosóficas, trata também de algo mais concreto, os caminhos pelos quais ele chegou à Itália e veio morar na vila Labirinto em Zagarolo.

É interessante notar esta ambiguidade entre algo concreto e algo mais poético, ou mesmo filosófico, já no título de sua autobiografia. É esse constante diálogo entre pensamento abstrato e experiência concreta que caracteriza a obra musicológica de Alain Daniélou, como se fosse necessário harmonizar diversos níveis simultâneos da experiência, para que ela seja melhor assimilada.

\footnotetext{
${ }^{10}$ Bérès brought out some of my more difficult works, such as the Traité de musicologie comparée and especially Sémantique Musicale, which challenges the basic principles of all the musical systems

${ }^{11}$ I felt, in fact, like a complete stranger in the land of my birth. By my way of thinking, feeling, living, I now belonged to another civilization.
} 
Este é um livro de memórias e Daniélou afirma em seu prólogo:

Eu não pretendo verificar os fatos e datas de que minha memória é incerta. Eu desejo apenas esboçar uns poucos retratos, de forma que aquelas sombras há muito idas possam agarrar-se a eles e reivindicar seu humilde lugar no ilusório e abençoado mundo dos vivos.

Eu nunca tomei notas; exceto por algumas poucas cartas, eu não guardei nenhum documento. As sombras do passado que eu despertar aparecerão por sua própria vontade, limitadas apenas pela minha memória, onde elas tem estado há muito adormecidas. ${ }^{12}$ (DANIÉLOU, 1987, p. 3)

Apesar desta afirmação reproduzida acima, é necessário um pouco de sua biografia para entender também a natureza de suas atividades, pois contar sua história é entender um pouco melhor todos os processos que o fizeram viajar pelo mundo e dedicar-se à cultura musical extraeuropeia.

No entanto, o que nos parece mais proveitoso para entender o pensamento de Daniélou, não é tanto quando ou onde tal e qual fato se deu, o que tornaria esta narrativa marcadamente historiográfica, e sim suas reflexões musicais, teóricas, filosóficas, ou mesmo religiosas, uma vez que é difícil dissociar o pensamento musical hindu de seu pensamento religioso. Procuraremos enfatizar mais estas reflexões que sua cronologia.

\subsubsection{Da Europa à Índia}

Daniélou nasceu em 1907 em Neuilly-sur-Seine (Paris) na França e morreu em 1994 na Suíça (CLOAREC, 2003) ${ }^{13}$. Sua família reúne diversas personalidades que não são só diferentes entre si como também tiveram importância histórica, principalmente na França.

Seu pai, Charles Daniélou, "um pai terno, mas ausente"14 (DANIÉLOU, 1987, p. 21), foi prefeito de Locronan durante 30 anos e ministro de estado de Aristide Briand. Era um radical anticlericalista. Sua mãe, Madeleine Daniélou, considerada por Alain como "uma

\footnotetext{
${ }^{12}$ I do not intend to verify the facts and dates of which my memory is unsure. I wish only to sketch a few portraits so that long-gone shadows may cling to them and reclaim their humble place in the illusory and blessed world of the living.

I have never taken notes; apart from a few letters, I have kept no documents. The shadows of the past that I shall reawaken will appear of their own free will, bounded only by my memory, where they have long lain asleep.

${ }^{13}$ Mais informações biográficas em $<$ http://www.alaindanielou.org $>$

${ }^{14}$ A descrição do pai e da mãe de Daniélou aqui, são títulos dos subcapítulos de sua autobiografia.
} 
santa" (DANIÉLOU, 1987, p. 13), não sem uma ponta de ironia, foi uma católica fervorosa, e chegou a fundar uma ordem religiosa, chamada São Francisco Xavier (Saint François-Xavier), para professoras sob os auspícios do papa Pio X. Criou também o Colégio Santa Maria "que era frequentado, na sua maioria, por jovens garotas da alta burguesia da época" (DANIÉLOU, 1987, p. 36 destaque do autor).

Seu irmão Jean Daniélou, dois anos mais velho que ele, foi um padre jesuíta e veio a ser nomeado cardeal pelo papa Paulo VI. Foi um estudioso respeitado, tendo publicado diversos livros sobre história da religião católica bem como sobre teologia. Morreu de ataque cardíaco no quarto de uma prostituta, o que causou grande escândalo na época. A este respeito Daniélou afirma: "Eu admirei profundamente a forma como ele morreu, e não poderia deixar de pensar sobre aqueles mártires cujo espírito sobe direto para o céu sob uma nuvem de infâmia e entre a zombaria das multidões"16 (DANIÉLOU, 1987, p. 28).

Apesar de discordar da religião de seu irmão, uma vez que Alain Daniélou defendia o politeísmo, o admirava por não ter preconceitos burgueses e pela sua simpatia pelos desafortunados, bem como por suas tentativas de ajudar prisioneiros, delinquentes e prostitutas, e afirma que ele chegou a celebrar missas para homossexuais (DANIÉLOU, 1987, 28). Além de Jean, Daniélou teve quatro irmãos mais novos: Catherine, François, Louis e Marie.

Desde criança, Daniélou sempre admirou os mistérios do mundo e da natureza. Isolava-se num bosque que havia próximo à casa que seu pai havia construído em Brittany, onde a família costumava passar o verão, e se dedicava a uma espécie de religião da natureza. Construiu um altar onde colocava, cruzes, imagens da Virgem Maria e mesmo pequenos seixos redondos. Inventava rituais e sentia uma profunda unidade com a natureza.

Quando foi descoberto pela família, consideraram-no um santo. E por influência de sua mãe, o papa Pio X autorizou sua primeira comunhão, embora tivesse apenas quatro anos. Tal situação não o agradou, pois muito mais do que a religião num sentido humano e abstrato, ele sentia a religião sempre de uma maneira concreta, ligada às sensações e à natureza, uma vez que "a religião dos homens não tem nada a ver com a divina realidade do mundo" (DANIÉLOU, 1987, p. 6). Ele veio a encontrar tal perspectiva na religião Shivaísta Hindu.

Daniélou foi criado por tutores, pois quando criança os médicos diagnosticaram que ele viveria pouco, então não valia a pena colocá-lo numa escola. Sua mãe no entanto, que era

\footnotetext{
${ }^{15}$ Which was attended by most of young girls of the Catholic haute-bourgeoisie of the time.

${ }^{16}$ I deeply admired the way he died, and could not help thinking of those martyrs whose spirit rises straight to Heaven under a cloud of infamy and among the jeerings of the crowds.
} 
uma pessoa bastante autoritária, teve um peso bastante forte em sua criação, sempre colocando seu irmão e seu tio Paul a aconselhá-lo, devido ao seu temperamento um pouco rebelde.

Alain Daniélou sempre foi uma espécie de ovelha negra da família, ou um enfant terrible para usar uma expressão francesa. Começando pela sua orientação sexual, já que era homossexual e desde cedo já sabia disso, tendo se assumido numa época em que tal orientação não era tratada com muita naturalidade. Sai de casa aos 21 anos e vai morar em Paris. Sua mãe concorda em pagar o aluguel mas logo cessa, por desaprovar a vida que ele levava. No entanto, seu pai e sua avó lhe ajudavam secretamente (DANIÉLOU, 1987, p. 1819).

Neste período em Paris convive com membros do meio artístico e literário da época. Conhece Max Jacob, Henry Sauguet, Jacques Dupont, Nikolas Nabokov - compositor, primo do autor de Lolita, Vladimir Nabokov, George Henry Rivière e Maurice Sachs, famoso cronista da Paris dos anos 20, que morava em Montmartre no Hotel Nollet, onde costumavam se reunir (DANIÉLOU, 1987, p. 73).

Embora se sentisse confortável nesta atmosfera não hostil, Daniélou não concordava inteiramente com as concepções artísticas deste meio, considerando esnobe a atitude de rejeitar tudo que parecesse óbvio. Ele observa:

Era considerado elegante dizer que Eric Satie era sublime e Brahms e Wagner abomináveis. Maurice tentou me convencer que Picasso, no seu período cubista era o auge da realização artística, e Monet, que eu adorava, completamente desinteressante. [...] Eu nunca saí do meu caminho para encontrar as pessoas da moda do mundo artístico e intelectual da época. ${ }^{17}$ (DANIÉLOU, 1987, p. 73-74)

Daniélou estudou piano desde os dez anos e aprendeu a pintar sozinho aos 13. Para ele pintar era "um modo de comungar com a beleza do mundo em uma linguagem que expressa sentimentos melhor do que qualquer palavra pode fazer. [...] $\mathrm{O}$ ato de pintar logo se tornou um tipo de rito extático semi-consciente, e sempre permaneceu assim"18 (DANIÉLOU, 1987, p. 50).

\footnotetext{
${ }^{17}$ It was considered elegant to say that Erik Satie was sublime and Brahms and Wagner abominable. Maurice tried to convince me that Picasso in his cubist period, was the very height of artistic achievement and Monet, whom I adored, completely uninteresting. [...] I never went out of my way to meet the fashionable people from the artistic and intellectual world of the time.

${ }^{18}$ A way to commune with the beauty of the world in a language that expressed feelings better than any words can do. [...] The act of painting soon became a sort of ecstatic semi-conscious rite, and it has always remained so.
} 
Porém, é principalmente à dança que ele se dedica quando sai de casa. Teve aulas com Legat, que foi o famoso professor de Nijinsky, praticando ao ponto da exaustão. Estuda também dança acrobática e, embora já tivesse 20 anos e se considerasse velho para a dança, chega a dar vários recitais. Durante muito tempo foi conhecido como bailarino, vindo não só a criar e produzir seus próprios espetáculos como também a coreografar o trabalho de outros artistas. Foi também nesta época que serviu à Marinha.

É com essa mesma idade que começa a estudar canto com Charles Panzera, além de conviver com Max d'Ollone, que além de acompanhá-lo ao piano enquanto cantava ou dançava, foi seu professor de composição e orquestração, além de compartilhar gostos musicais e concepções estéticas. Max d'Ollone, era professor de composição do Conservatório de Paris e havia sido aluno de Gounod (DANIÉLOU, 1987, p. 106).

Pouco antes, em 1925, por influência de sua mãe, vai estudar "arquitetura na Ecole des Beaux-Arts e trabalhar no escritório de um arquiteto amigo de seu pai chamado Lemaresquier" (DANIÉLOU, 1987 p. 56). Na Ecole des Beaux-Arts se sentia bastante desconfortável pois lá lhe parecia faltar liberdade de expressão, sensibilidade e imaginação, que ele podia encontrar na música e na pintura. Além disso, comenta que assuntos básicos, como os diagramas das catedrais medievais, cujo interesse lhe fora despertado mais tarde quando estudava a arquitetura dos templos hindus, não foram vistos na Ecole des Beaux-Arts. Logo saiu de lá sem um mínimo arrependimento. (DANIÉLOU, 1987, p. 57)

Em 1929, o Governador da Argélia concede-lhe uma bolsa para estudar música árabe, a pedido de seu pai: “desde o começo eu me senti em casa no mundo árabe, eu passava longas horas com músicos e as famosas dançarinas Ouled-Naïl ${ }^{19}$. Eu joguei dominó nos cafés mouriscos e fiz alguns amigos - e testemunhei inclusive cerimônias extáticas sufis",20 (DANIÉLOU, 1987, p. 71).

Daniélou conheceu Raymond Burnier na década de 1930 sendo um dos companheiros mais duradouros de sua vida. Ele era um milionário suíço, neto do inventor de um produto para crianças feito à base de leite condensado, chamado Nestlé, que deu à família uma "vasta indústria e uma enorme fortuna" (DANIÉLOU, 1987, p. 78). Raymond Burnier ficou famoso por suas fotos dos templos medievais hindus.

É na companhia de Burnier que Daniélou vai a Kabul no Afeganistão, passando antes por Bombaim, conhecendo então a Índia. A partir de Kabul eles viajam para a pequena vila de

\footnotetext{
${ }^{19}$ Estilo de dança do ventre originada nos povos das montanhas Ouled-Naïl, na Argélia.

${ }^{20}$ From the start, I felt quite at home in the Arab world. I spent long hours with musicians and he famous OuledNaïl dancers. I played dominoes in Mourish cafés and made a few friends - I even witnessed ecstatic sufi ceremonies.
} 
Khamdesh, no Kafiristão (Terra dos Infiéis), província afegã mais tarde chamada de Nuristão (Terra da Luz) quando se tornou muçulmana. Raymond fotografou e filmou a vila, os nativos e suas danças, e foi feito um pequeno documentário (DANIÉLOU, 1987, p. 83-85 passim). Daniélou comenta que

Georges Henry Rivière, o famoso etnólogo, reuniu uma grande exibição das magníficas fotografias de Raymond, que ainda podem ser vistas no Musée de l'Homme, museu antropológico de Paris; ele também organizou uma exibição do documentário em Trocadéro. ${ }^{21}$ (DANIÉLOU, 1987, p. 85)

Depois de passar pelo Afeganistão, Daniélou e Raymond Burnier retornaram à Índia, visitando Lahore, Delhi e Benares até chegarem em Calcutá. Lá visitam Uday Shankar, que haviam conhecido antes em Paris. Uday Shankar era irmão do famoso sitarista Ravi Shankar, que Daniélou também havia conhecido em Paris, quando a companhia de dança de Uday por lá se apresentou, nesta época Ravi tinha por volta de 15 anos e ainda não havia se decidido entre a dança e a música.

Uday Shankar vivia com Alice Boner - herdeira suíça de uma grande fortuna - que foi a responsável pela sua volta à Índia para se dedicar integralmente à dança Kathakali. Ela também foi a responsável por incentivar Ravi Shankar a se dedicar seriamente à música e ao sitar, indo estudar com o sarodista Allaudin $\mathrm{Khan}^{22}$. Alice Boner, além de artista, foi uma estudiosa da arte indiana, principalmente de seus templos. Com relação à companhia de dança de Uday Shankar, Daniélou comenta que

a mais interessante contribuição de Alice foi no domínio dos figurinos. Os dançarinos indianos tradicionalmente usavam roupas bastante pesadas. Inspirada por antigos afrescos e esculturas medievais, Alice desenhou trajes, colares, joias e adornos que revelavam tanto quanto possível o corpo de seu belo dançarino. O que se passa hoje por trajes tradicionais do balé indiano, foi, de fato, inventado por uma artista de Zurique. ${ }^{23}$ (DANIÉLOU, 1987, p. 91)

\footnotetext{
${ }^{21}$ Georges Henri Rivière, the famous ethnologist, put together a large exhibition of Raymond's photographs, which can still be seen at the Musée de l'Homme, Paris's anthropological museum; he also organized a showing of the film at the Trocadéro.

${ }^{22} \mathrm{O}$ sarod é um instrumento indiano similar a um alaúde, porém seu corpo e seu braço são ocos, preenchidos por cordas que ressoam por simpatia; não tem trastes, possui uma escala em metal e é tocado com um plectro. Allaudin Khan foi pai e professor do também sarodista Ali Akbar Khan, que veio a fundar a AACM - Ali Akbar College of Music, dedicada à música indiana, nos Estados Unidos, mais informações em: $<$ http://www.aacm.org $>$.

${ }^{23}$ Alice's most interesting contribution was in the domain of costume. Indian dancers traditionally wore very heavy outfits. Inspired by ancient frescoes and medieval sculptures, Alice design costumes, necklaces, jewels, and trinkets that revealed as much as possible of her handsome dancer's body. What passes today for the traditional costumes of Indian ballet was in fact invented by an artist from Zurich.
} 
Após esta passagem por Calcutá, vão até Shantiniketan para conhecer o poeta Rabindranath Tagore - autor do poema Gitanjali, e primeiro não europeu a receber um Nobel de Literatura, em 1913 - e a escola que ele havia criado e onde morava. Embora os visitantes não pudessem permanecer por mais de três dias, Daniélou e Burnier passam dois meses lá instalados. Nesta estada, Daniélou transcreve alguns poemas de Tagore, com acompanhamento de piano, que foram posteriormente publicados pela editora Ricordi, na França.

Quando eles voltam para a Europa, Tagore os encarrega de visitar seus amigos para tentar conseguir sugestões de como obter fundos para sua escola. Eles criam a Associação dos Amigos de Tagore e fazem contatos com alguns nomes ilustres: "André Gide, Romain Rolland, Paul Valéry, Paul Morand, André Maurois, Georges Duhamel, Salvador de Mariaga, Benedetto Croce, Carlo Formichi, e assim por diante" (DANIÉLOU, 1987, p. 98-99), mas infelizmente não conseguiram nenhum tipo de ajuda. Depois desta primeira viagem, Daniélou e Burnier costumavam visitar Tagore anualmente por algumas semanas, até que Tagore convidou Daniélou pra ser o diretor musical de sua escola, cargo recusado por ele.

Anos mais tarde, em 1947, Rathindranath, filho de Rabindranath Tagore pede a Alain Daniélou a Orquestração de duas músicas de Tagore. Daniélou faz as orquestrações e faz uma rápida visita a Paris para se aconselhar com seu amigo e mestre Max d'Ollone, então eles compõem rapidamente arranjos para orquestra e banda de metais. Jana Gana Mana torna-se o Hino Nacional da Índia e Bande Mataran a Canção Nacional (DANIÉLOU, 1987, p. 94).

Em 1935, Burnier e Daniélou empreendem uma viagem de Paris a Calcutá de carro. Como tal viagem nunca havia sido feita, sugerem-lhes a companhia de um jornalista. Eles acabam levando Jacques Duflot, repórter do Candide e filho da atriz Huguet Duflot (DANIÉLOU, 1987, p. 114). Passam por diversos países: Líbano, Síria, Irã, Paquistão (que ainda era parte da Índia), até chegarem em Delhi na Índia. Daí seguiram para Benares, Calcutá e finalmente Shantiniketan.

Depois desta e de outras viagens que incluíram Estados Unidos, Filipinas, Japão, China e o Norte da África, em 1937 Daniélou e Burnier alugaram um grande palácio em Benares à beira do Rio Ganges chamado Rewa Kothi - que estava abandonado havia muito tempo e pertencera ao Marajá de Rewa - e em 1939 nele se instalam definitivamente (DANIÉLOU, 1987, p. 124).

Em Benares eles vivem por aproximadamente 16 anos. Daniélou estuda Sânscrito, Hindi, vina e filosofia hindu, de forma que é reputado no ocidente como um indianista. E como indianista publicou trabalhos sobre a filosofia e religião hindu, sobre a história da Índia, 
traduziu o Kama-Sutra entre outras realizações ligadas ao pensamento indiano, mais especificamente ao hinduísmo.

Durante um tempo ele se impôs a disciplina de ler apenas livros, jornais ou revistas em Hindi ou Sânscrito, para poder aprender as duas línguas. Dessa maneira tornou-se fluente em Hindi e pode estudar antigos tratados de música indiana em Sânscrito. Ao estudar estes tratados, bem como o instrumento vīna, passa a ter outra concepção a respeito tanto da música oriental quanto da própria música ocidental. Como ele relata:

Pouco a pouco eu fui iniciado num surpreendente mundo novo - a música da Índia. Mas embora fossem muito diferentes da música ocidental, os dois estilos permaneceram separados e distintos em minha mente e eu nunca tentei misturá-los. Os sistemas musicais, como os idiomas, não se misturam, mas é possível tornar-se gradualmente consciente das semelhanças entre eles, não na forma, mas no seu poder evocativo. Num certo nível eles podem parecer não ter nada em comum, mas um rāga pode expressar o mesmo sentimento, a mesma visão de mundo que um adágio de Beethoven ou um movimento de uma sonata de Chopin. ${ }^{24}$ (DANIÉLOU, 1987, p. 54)

e mais a frente, ao justificar o porquê não aceitou o cargo de diretor musical da escola de Tagore, afirma que não estava interessado em canções, pois

Em Benares, no entanto, quando entrei em contato com a grande tradição da música clássica indiana, eu descobri finalmente uma arte profunda, complexa, refinada e sutil, que me satisfez completamente e para a qual eu senti que poderia devotar-me de todo o coração. ${ }^{25}$ (DANIÉLOU, 1987, p. 147)

É a partir do contato com este "surpreendente mundo novo", e do estudo apaixonado desta "arte profunda, complexa, refinada e sutil" que Alain Daniélou vai escrever suas obras musicológicas, participando daquele campo de estudos crescente chamado Musicologia Comparada que a partir da década de 1950 passa a ser chamado de Etnomusicologia.

Daniélou mergulha de cabeça na cultura indiana, chegando a se converter à religião Shivaísta Hindu, recebendo como nome de iniciado Shiva Sharan, que significa o protegido

\footnotetext{
${ }^{24}$ Little by little I was initiated into an astonishing new world - the music of the India. But although it was very different from Western music, the two styles remained separate and distinct in my mind and I never tried to mingle them. Musical systems, like languages, do not mix; but one gradually becomes aware of the resemblances between them, not in form but in evocative power. On a certain level they may seem to have nothing in common, but a rāga can express the same feeling, the same vision of the world as a Beethoven adagio or a movement in a Chopin sonata.

${ }^{25}$ In Benares, however, when I came in contact with the great tradition of classical Indian music, I finally discovered a deep, complex, refined, and subtle art that fully satisfied me and to which I felt I could devote myself wholeheartedly.
} 
de Shiva. Seu conhecimento da religião hindu foi orientado inicialmente por Vijayanand Tripathi, um dos grandes intelectuais de Benares, que "além de sua grande erudição e de seu conhecimento da filosofia clássica, rituais e interpretação textual, ele também era iniciado nos profundos mistérios da doutrina tântrica e da yoga"26 (DANIÉLOU, 1987, p. 134).

Daniélou explica que um estrangeiro "é considerado um mleccha, um bárbaro que é assimilado à casta mais baixa dos artesãos"27 (DANIÉLOU, 1987, p. 136). Um mleccha só pode ser instruído nos altos ensinamentos da filosofia tradicional e da ciência se viver e pensar como um hindu, então ele teve que se tornar "um vegetariano estrito, [e] observar todos os costumes e tabus" 28 (DANIÉLOU, 1987, p. 135).

Vijayanand, encarregou seu filho mais velho Brahmanand de lhe ensinar shastri, que é a forma culta de Hindi falada por estudiosos e filósofos, e intercedeu junto a Swami Karpatri para que lhe fosse permitido assistir seu darshana (visão), que

é um tipo de recepção onde santos, iogues, ou reis permitem aos seguidores contemplá-los em silêncio. Às vezes eles permanecem quietos e imóveis; outras vezes eles conversam com um pequeno e seleto grupo sobre vários tópicos relacionados à filosofia, dogma ou mesmo eventos correntes. ${ }^{29}$ (DANIÉLOU, 1987, p. 137-138)

Swami Karpâtrî era um sannyasi - um monge andarilho - considerado o líder espiritual de uma grande parte do norte da Índia. Era um homem dotado de um espantoso conhecimento. Ele pediu a Brahmanand que realizasse os ritos de iniciação de Daniélou e de Burnier, descrito com riqueza de detalhes em sua autobiografia. Depois dessa iniciação, Daniélou comenta que

tudo foi muito simples, como uma espécie de jogo, sem drama ou mistério aparente. Eu passei de um estado para outro sem saber; mas pouco a pouco eu notei que eu não era mais o mesmo, que a vida tinha uma nova base, novos propósitos, metas e deveres - que eu finalmente me tornara o que havia sido destinado desde o início. ${ }^{30}$ (DANIÉLOU, 1987, p. 141)

\footnotetext{
${ }^{26}$ Aside from his great learning and his knowledge of classical philosophy, rituals, and textual interpretation, he was also initiated into the deepest mysteries of tantric doctrine and yoga.

${ }^{27}$ Is considered a mleccha, a barbarian who is assimilated with the lowest castes of artisans

${ }^{28}$ a strict vegetarian, observe all the customs end taboos

${ }^{29}$ Is a kind of reception where saints, yogis, or kings permit their followers to contemplate them in silence. Sometimes they remain quite still and motionless; at other times they converse with a small, chosen group on various topics relating to philosophy, dogma or even current events.

${ }^{30}$ All this was very simple, like a kind of game, with no drama or apparent mystery. I passed from one state to another without knowing it; but little by little I realized that I was no longer quite the same, that life had a new basis, new purposes, goal, and duties - that I had finally become what I had been meant to be all along
} 
Mais tarde, quando Swami Karpâtrî criou o Dharma Sangh, um movimento em defesa do hinduísmo contra as correntes modernas, ele e Daniélou, que também era um defensor destes valores, se aproximaram mais e longas conversas foram travadas. Tal defesa dos valores tradicionais hindus, se deu inicialmente não como um movimento político a favor da independência indiana, pois

O inimigo do Dharma Sangh não era o Império Britânico, cujos representantes nunca interferiram com os ritos e religião dos hindus. O que parecia ainda mais perigoso para os tradicionalistas era o falso hinduísmo dos indianos anglicizados, que defendiam adaptar as doutrinas hindus tradicionais às concepções cristãs, consideradas mais relevantes para a realidade modernas. A verdadeira guerra deveria ser feita contra os chamados ashrams, que exploravam a ingenuidade das pessoas, contra o teosofismo, Aurobindo, os seguidores de Ramakrishna, mas especialmente contra os políticos. ${ }^{31}$ (DANIÉLOU, 1987, p. 138-139)

Embora Daniélou fosse a favor da independência da Índia - conhecendo e se relacionando com Nehru e sua irmã Vijaya-Lakshmi Pandit -, assim como Tagore não nutria simpatia pelo seu principal líder, Gandhi. Em vários momentos em The way to the labyrinth ele faz críticas às suas atitudes. Os políticos a que se refere acima são justamente aqueles que não estariam interessados na cultura indiana, justamente por serem anglicizados. Daniélou considera Gandhi um desses políticos:

Gandhi me parecia o próprio tipo de reformador moderno, mais cristão que hindu, como um Dom Quixote lutando contra problemas que não existem tais como o sistema de castas e os chamados "intocáveis", que gerou considerável publicidade a seu favor entre os socialistas britânicos, mas nenhum interesse real no povo indiano. ${ }^{32}$ (DANIÉLOU, 1987, p. 139)

Talvez seja necessário um estudo mais aprofundado das relações entre política e religião hindus para entender o que significa este conservadorismo religioso que Daniélou defende, pois o próprio Daniélou foi acusado por um ex-colaborador de ter distorcido as doutrinas hindus em favor de seu próprio estilo de vida.

\footnotetext{
${ }^{31}$ The enemy of the Dharma Sangh was not the British Empire, whose representatives never interfered with the rites and religion of the Hindus. What seemed far more dangerous to the traditionalists was the false Hinduism of anglicized Indians, who claimed to adapt traditional Hindu doctrines to Christians conceptions, considered more relevant to the realities of the modern age. The true war had to be waged against the socalled ashrams, which exploited people's gullibility, against theosophism, Aurobindo, Ramakrishna followers, but especially against politicians.

${ }^{32}$ Gandhi seemed the very type of the modern reformer, more Christian than Hindu, fighting like Don Quixote against nonexistent problems such as the caste system and so-called "untouchables", which generated considerable publicity in his favor among British socialists but not really interest the Indian people
} 
Jean-Louis Gabin, que fez apresentações e edições de diversos livros de Daniélou, lançou em 2010 o livro L'Hindouisme traditionnel et l'interprétation d'Alain Daniélou ${ }^{33}$, em que aponta diversas imprecisões ou mesmo distorções e interpretações deliberadamente falsas de Daniélou, porém não detecta nenhum problema em seu trabalho musicológico. Veremos adiante, no capítulo 3. Como?, como é possível analisar as possíveis "más" interpretações de Daniélou.

Os estudos musicais de Daniélou se dão com o mestre da vinna Shivendranath Basu, conhecido como Shantu Babu, que era considerado um dos maiores instrumentistas da vinna do norte da Índia. Daniélou descreve seu aprendizado com Basu, que se deu durante seis anos, como muito exigente:

No início, tudo que eu podia fazer era ouvir os rāgas e reconhecê-los. Depois de um tempo, ele permitiu que eu tomasse notas sobre os diferentes modos e qualidades emocionais dos intervalos. Com maravilhosa paciência ele explicou e demonstrou as sutilezas dos ornamentos e a exata afinação das notas, que difere de acordo com os rāgas.

Ele me deu uma pequena vinna então eu podia praticar a música e verificar minhas anotações, mas me proibiu de tocar para ele. "Você arruinaria meus ouvidos", ele disse, "Eu não suportaria". ${ }^{44}$ (DANIÉLOU, 1987, p. 147-148)

Como Basu tocava os rāgas de acordo com as regras que determinam que eles só podem ser tocados em determinadas horas do dia, Daniélou era obrigado a ir vê-lo tocar nos horários mais diferentes, desde as seis horas para os rāgas da manhã até às 22 horas para os rāgas da noite. Para tornar mais rápida sua ida até a casa de Basu ele comprou um barco.

A cada dia eu ia Ganges abaixo de barco para o ghat [degrau] próximo à casa de Shantu Babu; quando voltava para casa, eu praticava várias horas por dia. Depois de dois anos, me foi permitido tocar por alguns momentos na presença de meu mestre. [...] Depois de estudar por quatro anos, Shantu Babu ainda me criticava por minha terrível performance e dizia-me que eu não era bom para nada; mas para qualquer um que ia ouvi-lo, ele dizia: "Ele é meu melhor aluno, um músico verdadeiro, o único capaz de continuar minha tradição". Finalmente ele me deu um lindo instrumento antigo, que pertencera a um famoso músico do último século. E também me foi dada a grande honra - uma honra concedida apenas a um discípulo favorito - de carregar seu instrumento quando ele ia a algum lugar realizar um concerto,

\footnotetext{
${ }^{33}$ GABIN, Jean-Louis. L'Hindouisme traditionnel et l'interprétation d'Alain Daniélou. Paris: Éditions du Cerf, 2010.

${ }^{34}$ In the beginning, all I was supposed to do was listen to the rāgas and recognize them. After a while, he allowed me to take notes on the different modes and the emotional qualities of the intervals. With wonderful patience he explained and demonstrated the subtleties of the ornaments and the exact pitch of the notes, which differs according to the rāgas.

He gave me a small vīna so that I could practice the music and verify my notations, but forbade me to play in front of him. "You would ruin my ears", he said. "I could not bear it".
} 
um dever que eu pratiquei com reverência. ${ }^{35}$ (DANIÉLOU, 1987, p. 148)

No entanto,

eu estudei com ele por seis anos. Então, um dia, eu perdi a paciência. Eu não tinha mais energia suficiente para suportar os caprichos do venerável homem, sempre ter que implorar para tocar, sempre ouvindo as mesmas histórias absurdas sobre músicos que poderiam evocar a primavera ou a noite e queimar cidades inteiras até as cinzas pela força do rāga do fogo, que ele prudentemente recusava-se a tocar, mostrando-me apenas um esboço. ${ }^{36}$ (DANIÉLOU, 1987, p. 148)

Eu parei de ir às minhas aulas subitamente, o que causou muito pesar em Shantu Babu; ele queixou-se amargamente, e com boa razão, de minha ingratidão. Este sempre foi um de meus maiores defeitos. Minha paciência parece sem limites até o dia em que eu subitamente sinto que tenha o bastante e faço um claro rompimento, sem nenhuma possibilidade de volta. Minha excessiva paciência não me deixa energia para negociação, e eu não vejo outro caminho senão fugir. ${ }^{37}$ (DANIÉLOU, 1987, p. 149)

A esta altura Daniélou já tinha alguma reputação como músico e musicólogo na Índia, então em 1950 ele foi nomeado presidente do importante festival All India Music Conference de Calcutá, além de ser convidado, junto com o cantor Omkarnath Thakur, a organizar uma escola de música na Universidade Hindu de Benares. Thakur tornou-se diretor e Daniélou diretor assistente e professor, além de criar um centro para pesquisas em documentos musicais escritos em Sânscrito.

Daniélou coletou centenas de documentos sobre teoria musical escritos entre 500 a. C. até o século XVI, e durante este período publicou vários artigos sobre música em Sânscrito.

Sobre esta coleta de documentos Daniélou comenta:

\footnotetext{
${ }^{35}$ Each day I would go down the Ganges by boat to the ghat closest to the Shantu Babu's house; when I got home, I practiced for several hours a day. After two years, I was allowed to play for a few moments in front of my master. [...] After I had studied for four years, Shantu Babu was still criticizing me for my terrible playing and telling me that I was good for nothing; but to anyone who would listen to him, he would say: "He's my best pupil, a true musician, the only one capable of continuing my tradition". Finally we [sic] gave me a beautiful old instrument which had belonged to a famous musician of the last century. I was also granted the great honor - an honor only bestowed on a favorite disciple - of carrying his instrument when he had to go somewhere to give a concert, a duty I performed with reverence.

${ }^{36}$ I studied with him for six years. Then, one day, I lost patience. I no longer had enough energy to bear the caprices of the venerable man, always having to beg him to play, always listening to the same absurd stories about musicians who could evoke spring or night and burn entire cities to ashes by the force of the fire rāga, which he prudently refused to play himself, only showing me the outline.

${ }^{37}$ I stopped going to my lessons quite suddenly, which caused Shantu Babu much distress; he bitterly complained, with good reason, of my ingratitude. This has always been one of my greatest faults. My patience seems without limit until one day I suddenly feel that I have had enough and make a clean break, with no possibility of ever turning back. My excessive patience leaves me no strength for negotiation, and I see no other way but escape.
} 
Primeiro eu tinha que encontrar os manuscritos em bibliotecas públicas ou privadas, então recopiá-los, e finalmente transcrevê-los para Devanagari, o alfabeto Sânscrito clássico - porque mesmo em Sânscrito, cada província usa um sistema de escrita diferente. ${ }^{38}$ (DANIÉLOU, 1987, p. 149)

Neste centro de pesquisa Daniélou reuniu documentos sobre mais de oitocentos trabalhos, além de preparar mais de três mil index cards. Este material foi doado e encontra-se arquivado e disponível na seção oriental da Fundação Giorgio Cini, em Veneza.

\subsubsection{Da Î́ndia à Europa}

Eu não sou "um amante da Índia", eu sou um hindu, um seguidor da antiga cultura, vivendo em exílio. ${ }^{39}$ (DANIÉLOU, 1987, p. 219)

Daniélou relata que durante dez anos ele e Burnier passaram vários meses por ano viajando em um trailer por toda a Índia. Foi assim que visitaram o Templo do Sol de Konarak. Um templo da época medieval indiana adornado com esculturas eróticas, cujas belas fotografias feitas por Raymond Burnier deram-lhe importante reputação. Stella Kramrisch, professora de arte indiana na Universidade de Calcutá utilizou fotografias de Burnier em seu livro O Templo Hindu.

Rewa Kothi, o palácio em que Daniélou e Burnier viviam à beira do Ganges, serviu também como passagem e estadia para muitos visitantes, artistas e pesquisadores que passavam pela Índia. Um desses artistas foi o cineasta Jean Renoir, que em 1950 foi à Índia filmar The River, baseado num romance de Rummer Godden. Nesta visita, em que procurava uma atriz indiana, é apresentado por Daniélou a Rhada, filha do vice-presidente da Sociedade Teosófica. Renoir imediatamente se encanta com ela e, dando-lhe mais importância, transforma o que seria seu papel, o que torna necessário adicionar uma maior ambiência indiana ao filme, acrescentando fundos musicais com música indiana providenciada por Daniélou.

$\mathrm{Na}$ época, Burnier tinha um affair com Radha e, por ciúmes de Renoir, casa-se com

\footnotetext{
${ }^{38}$ First I had to find the manuscripts in public or private libraries, then have them recopied, and finally transcribe them into devanagari, the classical Sanskrit alphabet - for even in Sanskrit, each province uses a different writing system.

${ }^{39}$ I am not "a lover of India", I am a Hindu, a follower of the ancient culture, living in exile.
} 
Radha, o que se transforma num escândalo que praticamente obriga a saída dele e de Daniélou de Benares. Daniélou explica que quando ele e Burnier se iniciaram no hinduísmo juraram nunca se casar com alguém que não fosse de sua casta:

O casamento de Raymond não era considerado válido pela lei hindu, mas era um grande constrangimento para nossos mestres e ainda mais escandaloso porque Radha, embora fosse teosofista, vinha de uma família de Brâmanes. Subitamente nós éramos estrangeiros novamente, homens sem fé ou lei que deveriam normalmente ser considerados párias, rejeitados pelas duas comunidades a que o casal pertencia. [...] Seu casamento colocou de fato um fim a um tipo de vida, mas também tornou possível para o mundo tradicional encontrar outro papel para mim e mandar-me de volta para o ocidente, onde eu estava apto a realizar o que talvez fosse minha verdadeira missão. ${ }^{40}$ (DANIÉLOU, 1987, p. 194)

É assim que após viver aproximadamente 16 anos em Benares, Daniélou vai para Madras (atualmente Chennai), no sul da Índia. O pai de Radha, então presidente da Sociedade Teosófica, lhe oferece o cargo de diretor da biblioteca de Adyar, no sul de Madras, que possuía uma vasta coleção de antigos manuscritos e textos Sânscritos. Em 1953, Daniélou deixa Benares definitivamente. Rewa Kothi transformou-se numa associação cultural americana e mais tarde foi doado à universidade de Benares.

Durante sua estada em Adyar, como diretor da biblioteca, Daniélou publica Sangita Ratnakara um grande tratado Sânscrito do século XII sobre teoria musical. Organiza a biblioteca e, após diversas viagens para a Itália, Inglaterra e principalmente França, para estudar métodos de restauração e preservação de documentos, inventa um sistema de conservação destes manuscritos. Benjamin Britten e Peter Pears costumavam visitá-lo em Adyar.

Daniélou começa a se sentir pouco a vontade no ambiente extremamente puritano da Sociedade Teosófica então, em 1956, o Conde Stanislas Ostrorog - embaixador francês na Índia, que costumava visitá-lo no Rewa Kothi, quando vivia em Benares, consegue-lhe um cargo no Instituto Francês de Indologia, recém-criado na cidade de Pondicherry também no sul da Índia, cujo diretor era Jean Filliozat.

Daniélou aproveita este episódio, em The way to the labyrinth, para tecer várias críticas ao que ele considera o pensamento científico:

\footnotetext{
${ }^{40}$ Raymond's marriage was not considered valid by the Hindu law, but it was a great embarrassment to our masters and all the more scandalous because Radha, though a theosophist, came from a family of Brahmans. Suddenly we were strangers again, men without faith or law who should normally have become outcasts, rejected by the two communities the couple belonged to. [...] His marriage did in fact put an end to a certain way of life, but also made it possible for the traditional world to find another role for me and send me back to the West, where I was able to accomplish what was perhaps my true mission.
} 
No Instituto, pediram-me para preparar uma serie de textos em Sânscrito na forma comumente conhecida como "edição crítica", um sistema muito estúpido e desprovido de imaginação. Isto significava que uma vez que o texto tenha sido editado de acordo com os manuscritos, alguém deveria preparar notas de todos os erros do transcritor, todas as possíveis falsas interpretações - ou seja, tudo que poderia ser eliminado para produzir algo legível. Para cada três linhas de texto frequentemente se preparavam três páginas de notas. Eu queria ilustrar alguns dos textos com lindas fotografias, mas isto foi considerado inaceitável. Disse-me o Professor Filliozat: "Fotografias artísticas não são científicas!" [...] Toda minha vida a palavra "científico" assombrou-me, negando tudo que é artístico, tudo da mente e do espírito que tenha qualquer valor; é uma palavra usada por mediocridades para esconder sua ignorância. Uma tradução deve ser sempre incompreensivelmente literal, nunca a transcrição de uma ideia ou de uma imagem. Diziam a meu respeito: "Ele toca música indiana, portanto é um artista; o que ele diz sobre música não pode ser científico". Felizmente, preparar edições "científicas" é um trabalho mecânico e muito fácil de se fazer, o que me deixou muito tempo para me concentrar em coisas mais sérias. $^{41}$ (DANIÉLOU, 1987. p. 205)

O Conde Stanislas Ostrorog, que o havia indicado para o Instituto em Pondicherry, já havia lhe recomendado que conhecesse o indianista francês Louis Renou, autor de vários livros sobre a cultura indiana. Tornaram-se amigos, e em uma ocasião ele saiu em sua defesa:

Em todo domínio eu sempre me deparava com a hostilidade dos "cientistas". Em uma ocasião, quando eu estava sendo criticado como sendo um "amador", Louis Renou ficou tão irritado que protestou publicamente: "Daniélou pode não ser familiarizado com nossos métodos, mas quando eu não entendo um texto, ele é o homem a quem recorro". Depois disso os indianistas franceses deixaram-me em paz. ${ }^{42}$ (DANIÉLOU, 1987. p. 205)

Aconselhado por Louis Renou, que certa vez lhe disse: "Você aprendeu o bastante; agora você deve fazer uso de seu conhecimento. Você tem trabalho suficiente até o fim da sua

${ }^{41}$ At the Institute, I was asked to prepare a number of Sanskrit texts in the form commonly known as "critical edition", a very stupid and unimaginative system. This means that once the text has been edited according to the manuscripts, one has to prepare notes of all the transcriber's errors, all the possible false interpretations - in fact everything that should be eliminated to produce something readable. For every three lines of text one often has to prepare two pages of notes. I wanted to illustrate some of the texts with beautiful photographs, but this was considered unacceptable. "Artistic photographs are not scientific!" Professor Filliozat told me. [...] All my life the word "scientific" has loomed over me, denying all that is artistic, everything of the mind and spirit that has any real value; it is a word used by mediocrities to hide their ignorance. A translation must always be incomprehensibly literal, never the transcription of an idea or an image. It has been said of me: "He plays Indian Music, therefore he is an artist; what he says about music cannot be scientific". Fortunately, preparing "scientific" editions is mechanical work and very easy to do, which left me plenty of time to concentrate on more serious things.

${ }^{42}$ In every domain I have always met with the hostility of "scientists". On one occasion, when I was being criticized as an "amateur", Louis Renou was so exasperated that he publicly protested: "Daniélou may not be familiar with our methods, but when I don't understand a text, he is the man that I turn to". After that, French Indianists left me in peace. 
vida"43 (DANIÉLOU, 1987, p 234), Daniélou deixa Pondicherry definitivamente em 1960 e se instala em Paris, onde começa a trabalhar na Escola Francesa do Extremo Oriente (Ecole Françoise d'Extrême-Orient).

Por meio de suas obras, publicadas na sua maioria quando de seu retorno à Europa, Daniélou procura mostrar o mundo hindu em seus muitos diferentes aspectos: filosófico, religioso, ético e artístico, pois entende que esta civilização tem muito pouco a ver com o quadro pseudomístico no qual tentam enquadrá-la. Para ele, a civilização indiana é a única sobrevivente das grandes civilizações antigas, e conhecer melhor suas possíveis contribuições poderia levar o pensamento moderno a um novo Renascimento. Por isso começa a estudar origens paralelas da antiguidade ocidental que o leva a publicar seu livro Shiva and Dionysus $^{44}$, em que entende estes dois deuses como duas versões de uma mesma divindade remota. (DANIÉLOU, 1987, p 234).

Durante sua estada em Benares, Daniélou gravou tanto os melhores representantes da música clássica indiana como cantos Védicos e canções populares da Índia. Graças ao interesse de Serge Moreux e seu assistente Roland de Candé, da gravadora francesa DucretetThomson, foi publicado a primeira Anthologie de la musique classique de l'Inde que inclui gravações do jovem Ravi Shankar.

Jack Bornoff, que era secretário executivo do Conselho Internacional de Música, persuadiu a UNESCO a criar uma série de discos sobre a grande música oriental e africana e contratou Alain Daniélou para ser seu consultor. Ele realiza gravações em diversos países: Afeganistão, Camboja, Laos, Irã, Japão, Tibete, Tunísia e Marrocos.

Com a morte de Serge Moreaux, e o desinteresse das gravadoras em músicas não ocidentais essas gravações foram lançadas posteriormente de modo pulverizado, em versões regionais, de acordo com o interesse de cada gravadora em cada país. Entre os diversos lançamentos, a Philips da Holanda lançou uma história da música tradicional em uma coleção chamada Les Sources Musicales e a E.M.I. italiana, dirigida por Michel Bonnet, lançou uma série chamada Atlas Musical.

Com o lançamento no ocidente destas séries de discos com música tradicional promovidas pela $\mathrm{UNESCO}^{45}$, os músicos que fazem parte destas coleções passam a ser vistos como músicos de prestígio internacional. Por conta deste prestígio eles deixam de ser

\footnotetext{
43 "You have learned enough; now you must make use of your knowledge. You have enough work to last till the end of your life"

${ }^{44}$ Publicado no Brasil como Shiva e Dioniso: a religião da natureza pela Martins Fontes. É seu único livro publicado no Brasil.

${ }^{45}$ Informações sobre a Coleção de Música Tradicional da UNESCO em

$<$ http://www.unesco.org/culture/ich/index.php?pg=00123 $>$.
} 
negligenciados, ignorados e desprezados em seus países de origem, as rádios começam a tocálos e sua situação financeira melhora. Daniélou afirma que estava "muito menos interessado em atrair a atenção dos ocidentais para a música oriental do que ajudar os músicos a manter sua tradição"46 (DANIÉLOU, 1987, p. 239).

Não por acaso, encontramos declarações de Ravi Shankar e de Yehudi Menuhin elogiando Alain Daniélou. Shankar afirma que foi devido a Alain Daniélou que a música indiana deixou de ser considerada um mero folclore para ser considerada uma música clássica, em pé de igualdade com a maior música e os maiores criadores ocidentais. Menuhin também elogia o trabalho de Daniélou por ter possibilitado este diálogo entre as músicas ocidentais e orientais.

Daniélou tem duas opções ao voltar definitivamente para Europa. Louis Renou the oferece um cargo de professor na Ecole de Haute Etudes em Paris, e Nicolas Nabokov sugere que ele crie um instituto para o estudo e propagação de músicas não europeias em Berlim. O Muro de Berlim foi construído em 1961, e a Fundação Ford estava disposta a financiar qualquer empreendimento cultural na Europa desde que fosse em Berlim. Então, recusando o posto oferecido por Louis Renou, ele cria em Berlim o Instituto de Estudos Musicais Comparados em 1963.

O Instituto reeditou e desenvolveu a revista do International Music Council, publicou trabalhos sobre música oriental e tornou possível aumentar a coleção de gravações, além de organizar congressos e concertos. Nele trabalharam músicos e pesquisadores como Hans Eckart, especialista em música japonesa; Kurt Rheinhardt, especialista em música turca; Pandit M. D. Pant, professor de Sânscrito; Jacques Brunet que trabalhou com música do Camboja e da Indonésia; o israelense Simha Arom, especialista em música africana, principalmente a dos pigmeus Aka; Christian Poche conhecedor da música árabe, substituído depois por Habib Touma, entre outros. Quando Daniélou deixa o Instituto de Estudos Musicais Comparados em Berlim, ele contabiliza 120 discos produzidos por ele e seu assistente Jacques Cloarec.

Daniélou conhece Ivan Vandor, que havia publicado trabalhos sobre música Tibetana e trabalhado no Instituto de Música Oriental na U.C.L.A., dirigido por Mantle Hood. Ele se torna também seu assistente e em 1976, Daniélou passa a direção do Instituto em Berlim para Vandor.

Em 1969, devido a dificuldades causadas pela interferência da administração

\footnotetext{
${ }^{46}$ [I was] far less interested in attracting the attention of Westerners to Oriental music than helping musicians maintain their traditions.
} 
municipal de Berlim - que havia tornado-se a financiadora do Instituto, uma vez que a Fundação Ford, de acordo com seu estatuto era forçada a cortar o financiamento após seis anos -, tornando difícil o contato com os países asiáticos influenciados pela União Soviética, Daniélou cria um segundo Instituto completamente independente em Veneza.

A Fundação Ford também contribuiu para este segundo Instituto de Estudos Musicais Comparados, e a Fundação Giorgio Cini cedeu espaço físico para sua instalação. Jacques Cloarec ficou encarregado dos departamentos administrativo e contábil. Daniélou doou sua coleção de livros sobre o Oriente para a divisão oriental da biblioteca San Giorgio da Fundação Giorgio Cini, o que incluía centenas de manuscritos, index cards e esboços para edições, ainda disponíveis para consulta e pesquisa. Em 1999 o Instituto foi incorporado oficialmente à Fundação Giorgio Cini com o nome de Istituto Interculturale di Studi Musicali Comparati (Instituto Intercultural de Estudos Musicais Comparados), atualmente é dirigido pelo professor Giovanni Giuriati e possui convênios com a Universidade Ca'Foscari de Veneza, com o Conservatório de Música di Vicenza e outras instituições ${ }^{47}$.

Depois de um tempo em Veneza, Daniélou vai morar em Zagarolo, numa vila chamada Labirinto, que juntamente com Praeneste (atual Palestrina), já foram consideradas os lugares mais sagrados do mundo antigo, um lugar de grande importância para o Renascimento, onde Francesco Colonna reuniu nomes como Giovanni Pico della Mirandola, Alessandro Farnese, Nicholas de Cusa e Leone Battista Alberti (DANIÉLOU, 1987, p. 232233 passim)

Entre prêmios, nomeações e condecorações diversas, Alain Daniélou foi membro honorário do International Music Council; membro nomeado da Academia Indiana de Música, Dança e Teatro; Professor Emérito pelo Senado de Berlim; Officier de la Légion d'Honneur, Officier de l'Ordre National du Mérite e Commandeur des Arts et des Lettres; além de ter recebido o prêmio UNESCO/CIM de música, em 1981 e em 1991 o prêmio Cervo para a música nova (CLOAREC, 2003, p. 210).

\subsection{Música e o Poder do Som (Tratado de Musicologia Comparada)}

O livro Music and the power of sound: the influence of tuning and interval on

\footnotetext{
${ }^{47}$ Informações obtidas em $<$ http://www.cini.it/it/institute/history/id/5>
} 
consciousness tem uma história curiosa: ele foi publicado pela primeira vez em Londres em 1943 com o título Introduction to the Study of Musical Scales. O próprio Daniélou o traduziu para o francês, publicando-o em 1959 como Traité de Musicologie Comparée. Em 1995, Rivers-Moore, com aprovação e cooperação de Daniélou, faz uma revisão completa da primeira versão inglesa, adaptando-a para o inglês moderno, e a reedita sob o título de Music and the Power of Sound. Temos, portanto, três versões para o mesmo livro (RIVERSMOORE, 1995, p. xiii). Adotaremos nesta tese a versão em língua inglesa mais atual, Music and the power of sound e quando necessário o Traité de musicologie comparée em sua tiragem de 2004.

Não é por acaso que a versão recente em inglês, Music and the Power of Sound, possui o subtítulo "a influência da afinação e do intervalo na consciência" (DANIÉLOU, 1995). O tema dos intervalos e de seu simbolismo numérico é muito caro a Alain Daniélou, e é a partir deste foco que ele vai discorrer inicialmente sobre questões da linguagem musical tais como a natureza dos sons musicais; série harmônica; construção de escalas e de relações musicais; medida dos intervalos e sua notação. É interessante notar que Daniélou concebe as notas musicais como doze regiões de altura, que variam conforme as relações intervalares e sua afinação, e não como doze alturas absolutas, ideia engendrada como consequência da plena adoção do temperamento igual na música ocidental.

\subsubsection{Correspondências metafísicas}

Daniélou parte do princípio que as ciências e as artes eram entendidas como aplicações diferentes de princípios comuns. Estes princípios comuns eram considerados como chaves para o conhecimento, elos entre aspectos físicos e metafísicos que permitiriam o entendimento das leis universais. Esses elos se davam principalmente por meio do simbolismo numérico, que na música se manifesta de maneira mais direta do que nas outras atividades (DANIÉLOU, 1995, p. 1). Ampliaremos este assunto na Parte 2 capítulo 1.

\section{Filosofia da Música: Heteronomia.}

Mais do que entender como o ser humano adquiriu o conhecimento dos intervalos, o mais importante é descobrir como se dá o fenômeno que permite que determinadas combinações sonoras evoquem diferentes sentimentos, emoções ou imagens. Segundo 
Daniélou, é por meio do estudo da metafísica tradicional, que mantém uma lógica e coerência interna, apesar das aparentes mudanças exteriores, que podemos entender as ligações possíveis entre os fenômenos sonoros e seus efeitos psicológicos. (DANIÉLOU, 1995, p. 2)

Apesar da aparente importância atual da ciência experimental, Daniélou recorda que diversos elementos de nosso sistema musical são simbólicos, como o são também padrões de medidas espaciais e temporais, e que tais elementos são utilizados e considerados como se fossem naturais apenas porque existem correspondências entre estes símbolos e o mundo real.

Citando diversos autores ligados a culturas tradicionais, como Confúcio e René Guénon e ainda obras como os Vedas indianos, chama a atenção para o fato de que nessas culturas a música é sempre considerada como a atividade que permite um conhecimento profundo do universo e de suas leis.

A palavra em Sânscrito para universo é jagat (aquilo que se move), e todo movimento gera uma vibração, que por sua vez pode ser associada a um som, este então seria um princípio comum a todo o universo. Neste sentido, esta afirmação estaria "afinada" com as descrições da matéria feitas após o advento da mecânica quântica. Como toda matéria pode ser entendida em termos de vibração e consequentemente de sons, ainda que inaudíveis, podese entender a relação entre os diversos elementos existentes como relações sonoras. "Nós podemos então entender porque a astrologia, a alquimia, a geometria e assim por diante se expressam em termos de relações harmônicas”48 (DANIÉLOU, 1995, p. 4).

Portanto, a música pode ser uma manifestação no plano audível destas relações encontradas no mundo, o que proporcionaria o poder de recriação das próprias coisas do mundo, como descrito nos Vedas e no Gênesis. Porém, se essas relações não podem ser reproduzidas de forma perfeita, o que proporcionaria o poder de criação, elas podem ao menos evocar tais criações, determinados sentimentos, emoções ou mesmo realidades de natureza espiritual (DANIÉLOU, 1995, p. 4).

A evocação através do som, como a própria criação, ocorre não devido ao fato material da vibração física, mas por conta da existência de correspondências metafísicas. Por isso toda explicação psicológica da experiência musical deve ser descartada. Na realidade, a personalidade do ouvinte não tem nenhuma importância no fenômeno da evocação musical porque a evocação ocorre mesmo se não há ouvinte, e se a existência desta evocação é efêmera é apenas devido à imperfeição da relação dos sons. Ouvintes podem ser diferenciados negativamente apenas com relação à perspicácia de sua percepção, sua maior ou menor surdez. [...] O trabalho do

\footnotetext{
${ }^{48}$ We can therefore understand why astrology, alchemy, geometry and so forth express themselves in terms of harmonic relations.
} 
músico consiste portanto, apenas em conhecer, tão precisamente quanto possível, as relações simbólicas de todas as coisas para reproduzir em nós, através da magia dos sons, os sentimentos, as paixões, as visões de um mundo quase real ${ }^{49}$ (DANIÉLOU, 1995, p. 4-5)

Segundo Daniélou, tanto os chineses, quanto os indianos e os gregos antigos acreditavam nesse poder de evocação da música, consideravam como ciência o conhecimento dessas conexões entre os sons e outros aspectos da realidade, e que hoje entendemos como magia ou superstição. Essas conexões se dariam por meio do conhecimento das leis matemáticas encontradas na música e em outros aspectos da realidade e da harmonia do mundo.

Os simbolismos numéricos ligados à música estão presentes nestas três civilizações. Com relação à China, Daniélou faz referência à citação de Guénon do Tao Te King "50 : "O um deu à luz o dois, o dois deu à luz o três, o três deu à luz todos os números" "51 (GUÉNON apud DANIÉLOU, 1995, p. 6) ${ }^{52}$. O que em termos musicais pode ser entendido a partir dos primeiros parciais de uma série harmônica, ou das primeiras divisões de uma corda. O 1 é a fundamental, o 2 sua oitava, e o 3 um intervalo de quinta, que ao ser repetido daria origem a todos os outros sons possíveis. Estes sons ao serem selecionados em grupos de 5 - formando uma escala pentatônica - manteriam, para os chineses, correspondência com "o mundo material, as cinco direções (quatro pontos cardeais e centro), os cinco elementos e assim por diante" (DANIÉLOU, 1995, p. 6).

Acrescentando dois sons a esses 5 encontraríamos o número 7, que já no diálogo Timeu de Platão representa as divisões da alma do mundo (PLATÃO, 2011, 34a-40d), mas

\footnotetext{
${ }^{49}$ Evocation through sound, like creation itself, takes place not because of the material fact of physical vibration but on account of the existence of metaphysical correspondences. Therefore all psychological explanation of musical experience has to be discarded. In reality, the personality of the hearer counts for nothing in the phenomenon of musical evocation because evocation takes place even if there is no hearer, and if the existence of this evocation is ephemeral it is only because of the imperfection of the relation of sounds. Hearers can be differentiated negatively only by the relative acuteness of their perceptions, their great or lesser deafness. [...] The work of the musician consists therefore only in knowing, as accurately as possible, the symbolic relations of all things so as to reproduce in us, through the magic of sounds, the feelings, the passions, the visions of an almost real world.

${ }^{50}$ No texto de Guénon, republicado posteriormente na coletânea de artigos Mélanges temos: "[...] suivant la formule du Tao-te-King: 'un a produit deux, deux a produit trois, trois a produit tous les nombres', (GUÉNON, 1976, p. 89 aspas do autor)

${ }^{51}$ One has given birth to two, two has given birth to three, three has given birth to all numbers.

${ }^{52}$ Reproduzimos aqui, a partir da tradução brasileira direta do chinês, todo o capítulo 42 As transformações do $D A O$ :

o curso gera o um / o um gera o dois / o dois gera o três / o três gera as dez-mil-coisas // as dez-milcoisas têm atrás sombra (Yin) / elas abraçam na frente a luz (Yang) / o éter vazio para compor a harmonia // o que os homens mais abominam / ser órfão viúvo indigente / reis e príncipes a si se intitulam // portanto // as coisas ora perder é ganho / ora ganhar é perda // a tradição dos homens eu também transmito: / os violentos não alcançam sua morte // eu o considerarei pai da doutrina (LAOZI, 2007, p. 125). Guénon explica que na língua chinesa o indefinido é representado pelo número dez mil (GUÉNON, 1976, p. 89).
} 
que também representa a imagem do mundo celestial e os sete planetas visíveis. O número 7 também se encontra no número de cordas da lira, nos sete tubos da flauta de Pã, nos sete passos de Dante para chegar ao paraíso e nos sete cavalos que puxam a carruagem de Sūrya, deus do Sol hindu (DANIÉLOU, 1995, p. 6-7).

O número sete pode ser entendido também como a soma do ternário e do quaternário $(3+4=7)$, que ao serem multiplicados geram o número doze $(3 \times 4=12)$. O dodecaedro representa para a tradição pitagórica o símbolo do universo. Os sete planetas se deslocam nas doze regiões do zodíaco, assim como as sete notas de nossa escala diatônica deslocam-se nas 12 regiões da oitava (DANIÉLOU, 1995, p. 7).

O número 12, mais do que uma série ou uma sequência dentro do simbolismo numérico, pode ser considerado uma área, em virtude de ser o resultado de um produto entre três e quatro. Assim, em relação à música, as doze notas de nosso sistema musical seriam relacionadas a regiões dentro das quais diversas alturas seriam possíveis de acordo com a afinação que se utilizasse, não se confundindo com 12 notas de alturas absolutas, como vieram a ser consideradas dentro do sistema de afinação do temperamento igual ocidental (DANIÉLOU, 1995, p. 6-7).

Desta forma a música para os antigos era mais do que uma mera fruição para os ouvidos, ela representava uma espécie de "álgebra de abstrações metafísicas" (de MENGEL apud DANIÉLOU, 1995, p. 7).

O ciclo de quintas, que ao passar por doze quintas não nos leva de volta à oitava, é explicado por Daniélou como um dos sinais da imperfeição necessária ao mundo para que ele não seja reabsorvido na infinita perfeição, assim como o eixo da terra é inclinado, o coração não se encontra no centro do peito e o ciclo solar não coincide com o ciclo lunar.

Essa pequena diferença existente no ciclo de quintas chamada de coma, é a diferença com a qual as diversas culturas com seus diversos sistemas musicais precisam negociar, é a diferença entre o que é finito e o que é infinito.

As quintas formam uma espiral na qual os sons, enrolados ao redor de si mesmos, nunca podem se encontrar. Para nós, essa espiral ilimitada pode ser a junta [articulação] na estrutura do mundo, o portão estreito que nos permitirá escapar da aparência de um universo fechado, para viajar em outros mundos e explorar seus segredos. ${ }^{53}$ (DANIÉLOU, 1995, p. 8)

\footnotetext{
${ }^{53}$ The fifths form a spiral whose sound coiled in themselves, can never meet. For us, this limitless spiral can be the joint in the structure of the world, the narrow gate that will allow us to escape from the appearance of a closed universe, to travel in other worlds and explore their secrets.
} 
Como veremos de forma mais detalhada no subcapítulo 2.3. Semântica Musical, Daniélou considera que embora o ouvido muitas vezes não perceba pequenas diferenças na precisão da afinação, nosso corpo, células, moléculas e principalmente nossa mente, estariam sujeitos a uma espécie de fadiga que teria como consequência uma espécie de estresse ao ouvir músicas que não levassem em conta essas pequenas diferenças, e no caso das culturas citadas acima, isso seria o mesmo que expelir da música seu aspecto celestial (DANIÉLOU, 1995, p. 4).

\subsubsection{O conflito dos sistemas musicais}

Daniélou considera que a diferença existente entre os sistemas musicais orientais e ocidentais, não é uma diferença fundamental, e sim uma diferença que se estabelece em virtude de uma contradição entre prática e teoria. Os princípios acústicos que regem a música nos diversos sistemas são iguais, é apenas em sua exteriorização, em sua atualização enquanto evento sonoro que tais diferenças se apresentam. Ele entende que, mais do que sistemas diferentes, são sistemas complementares (DANIÉLOU, 1995, p. 10-11).

Os sistemas musicais, de maneira geral, trabalham com sons que possuem apenas uma fundamental. Um grupo de notas que formam uma escala ou um modo são definidas de acordo com determinadas relações entre si que podem ser representadas por razões numéricas. A significação de cada som, portanto, depende da localização que cada nota possui dentro de um determinado modo ou escala, sua relação com uma tônica ou uma finalis, o que faz com que cada nota possa ser interpretada como repouso ou como movimento, de acordo com sua posição em uma determinada melodia. Daniélou cita Gounod, que afirma que assim como uma linguagem não se forma com palavras soltas, uma música não se faz com sons isolados, é preciso uma sintaxe e uma estrutura que os una e que faça com que eles adquiram sentido (apud DANIÉLOU, 1995, p. 12) ${ }^{54}$.

\footnotetext{
${ }^{54}$ No original: Les sons, à eux tout seuls, ne constituent pas plus la musique que les mots tout seuls ne constituent le langage : les mots ne forment une phrase, un membre de phrase, en une mot, une proposition intelligible quelconque, que s'ils sont associes entre eux par un lien logique, répondant aux lois de l'entendement.

Il est de même des sons qui ne deviennent une réalité musicale, que lorsqu'ils obéissent à certaines lois qui régissent leur production successive ou simultanée : c'est alors, seulement, qu'ils appartiennent au domaine de l'art et à la langue musicale (GOUNOD, 1882, p. 58).

[Os sons, sozinhos, não constituem mais música do que as palavras por si só não constituem a
} 
Embora o número de possíveis intervalos seja teoricamente infinito - devido à nossa capacidade de discriminação auditiva e à consonância de alguns intervalos, além das questões simbólicas dos números mostradas acima -, apenas alguns são utilizados na prática musical. A partir desta observação, Daniélou elabora a hipótese que justifica a construção de uma escala especial:

Se na prática musical apenas um pequeno número de intervalos que possua razões definidas entre eles pode ser usado, deve ser possível criar uma escala que permita todas as possíveis combinações destas razões. Para determinar tal escala, devemos tentar descobrir as leis dos números sobre as quais tal divisão deve ser necessariamente baseada, e devemos estudar os métodos usados na aplicação destas leis na prática musical por diferentes povos em diferentes períodos. Então, comparando as estruturas dos mais importantes sistemas, veremos se é possível trazer todos os intervalos que eles utilizam para um único quadro sem distorcê-los como faz o temperamento igual. ${ }^{55}$ (DANIÉLOU, 1995, p. 12)

Nesta investigação Daniélou afirma que os intervalos se apresentam em dois aspectos: em suas proporções matemáticas e lógicas e em seu aspecto expressivo, simbólico e psicológico, que despertariam sentimentos, ideias e visões a partir de sua harmonia. Estes dois aspectos teriam origem nos mesmos princípios que, segundo Daniélou, por estar além do caráter experimental, estariam além do entendimento dos ocidentais modernos, pois se trata de princípios metafísicos de correspondências (DANIÉLOU, 1995, p. 13).

Esses dois aspectos nutriram as compilações sobre teoria musical de acordo com as diversas circunstâncias como o tempo, pessoas e lugar. Quando a ênfase é colocada no aspecto expressivo, haveria o nascimento da música modal em seu aspecto de relacionamento das diversas notas com uma tônica, e seria baseada no intervalo de oitava. Quando ênfase foi colocada no aspecto numérico, a base para a construção de tal teoria seria o ciclo de quintas em seu aspecto modulatório e harmônico. Contudo, nesta aparente dualidade ainda estariam preservados os aspectos metafísicos (DANIÉLOU, 1995, p. 13).

linguagem: as palavras não formam uma frase, um membro de frase, uma palavra, qualquer proposição inteligível se não são associadas entre si por um nexo lógico, respondendo às leis do entendimento.

São os mesmos sons que se tornam uma realidade musical somente quando obedecem a certas leis que regem a sua produção sucessiva ou simultânea: é só então que eles pertencem ao campo da arte e da linguagem musical]

${ }^{55}$ If in musical practice only a small number of intervals can be used that have definite ratios between them, it must be possible to devise a scale that allows all possible combinations of such ratios. To determine such a scale we must attempt to discover the laws of numbers on which such a division must necessarily be based, and we must study the methods used in the application of these laws to musical practice by different peoples at different periods. Then, comparing the structures of the most important systems, we shall see whether it is possible to bring all the intervals that they use within a single framework without distorting them as equal temperament does. 
Daniélou entende que a música modal depende essencialmente de uma tônica à qual todas as outras notas se referem por meio de razões precisas de afinação. É importante que esta tônica mantenha-se presente durante a música, como um bordão ou como uma nota que se repete constantemente, garantindo a precisão da afinação de cada nota pelo executante. É assim na música indiana com a nota $\mathrm{Sa}$, que soa constantemente nas tamburas, é assim com a nota ou pedal denominado Ison no canto bizantino. Por sua vez, "a mesa [sic] ${ }^{56}$ era, para a música grega antiga, o que o ison é para a música moderna Bizantina"57 (DANIÉLOU, 1995, p. 14). Daniélou considera que a perda desta tônica seria a responsável pela vagueza e sensação de etéreo no caso do cantochão ocidental, como no canto gregoriano ou ambrosiano, por exemplo (DANIÉLOU, 1995, p. 14-15).

Caso houvesse uma mudança de tônica esta música modal se desagregaria. Tal situação é diferente na música que se baseia no ciclo de quintas, uma vez que a própria ideia de modulação está presente em sua construção. Esta modulação seria responsável por todas as notas manterem uma relação simples com uma tônica que, ao ser mudada, mudaria por consequência todas estas relações. É esse o sistema no qual se baseia a música chinesa, por exemplo, e em certos aspectos a música ocidental tonal.

Segundo Daniélou, a música tonal ocidental é desprovida de uma teoria racional ${ }^{58}$. Ela foi desenvolvida utilizando aspectos destas duas diferentes teorias. Seu desenvolvimento harmônico, contudo, ocorreu com uma destruição paralela da música modal, principalmente com a adoção progressiva do temperamento igual. Ainda que se considere possível uma combinação de ambas as expressões, harmônica e melódica, o desenvolvimento harmônico torna as sutilezas melódicas praticamente impossíveis. Cita ainda Rousseau em sua crítica à harmonia da música ocidental, e acha irônico que tal crítica não seja levada a sério pelos mesmos que aceitam suas outras definições (DANIÉLOU, 1995, p. 16-17).

Como hipótese que permitiria analisar os diferentes sistemas musicais, afirma então que pretende usar a lógica da razão: “portanto, ao julgar as possibilidades e o valor dos sistemas musicais, não deveríamos confiar no julgamento preconceituoso dos nossos ouvidos,

\footnotetext{
${ }^{56}$ Daniélou usa aqui a grafia mesa, no entanto, consultando a obra $A$ música grega de Théodore Reinach (2011), observamos, numa nota de tradução (p. 40n), que a grafia grega para esta palavra é $\mu \varepsilon \sigma \eta$, cuja transcrição na tradução brasileira é mesē (p. 40). Por este motivo, optamos por utilizar nesta tese a grafia mesē, mesmo quando forem paráfrases do texto de Daniélou; quanto às citações literais, manteremos a grafia mesa porém seguida da observação [sic].

${ }^{57}$ The mesa [sic] was, to ancient Greek music, what the ison is to modern Byzantine music.

${ }^{58}$ Aqui o que Daniélou chama de irracional talvez queira dizer apenas incoerente. Weber por sua vez afirma que "toda música racionalizada harmonicamente parte da oitava (relação de frequências 1:2) e a divide nos dois intervalos de quinta (2:3) e quarta (3:4)" (WEBER, 1995, p. 53), desta maneira, todas as culturas citadas por Daniélou compartilhariam desta concepção de racionalidade de Weber.
} 
mas considerar em sua forma mais abstrata suas possibilidades teóricas" ${ }^{, 59}$ (DANIÉLOU, 1995, p. 18).

\subsubsection{A medida dos intervalos e dos sons harmônicos}

Daniélou descreve a notação que criou para definir os diferentes intervalos presentes nos diversos sistemas musicais. Segundo ele, a forma mais simples de medir um intervalo é por meio da razão entre o comprimento da corda ou do tubo, ou da razão entre as frequências, sendo uma o inverso da outra. Assim, para um intervalo de segunda maior, devemos utilizar $8 / 9$ do comprimento de uma corda ou tubo, ou multiplicar por $9 / 8$ a frequência a qual se quer acrescentar o referido intervalo.

Por exemplo, supondo que uma corda solta emita a nota $\mathrm{C}_{4}(\mathrm{Sa})=512 \mathrm{~Hz}$, se diminuirmos seu comprimento em um nono teremos a nota $\mathrm{D}_{4}(\mathrm{Re})$; ou se multiplicarmos sua frequência por $\frac{9}{8}$ teremos a frequência da nota $\mathrm{D}_{4}(\mathrm{Re}): 512 \times \frac{9}{8}=576 \mathrm{~Hz} 60$.

Apesar da simplicidade deste sistema, é difícil analisar de maneira rápida qual intervalo é maior que outro sem o auxílio de cálculos. É preciso uma transposição destas razões para uma notação linear. Daniélou adota a medida em savarts que descreve da seguinte maneira: "se tomarmos o logaritmo (base 10) da razão da frequência e, por conveniência, multiplicar por mil, teremos o intervalo expresso em termos da unidade conhecida como savart" ${ }^{\prime 61}$ (DANIÉLOU, 1995, p. 20)

A oitava, quando expressa em razão de frequência é igual a dois, o logaritmo de dois é 0,30103 que ao ser multiplicado por mil resulta em 301,03 que pode ser arredondado para 301 savarts. Dessa maneira fica mais fácil e rápido observar a diferença entre intervalos. Por exemplo:

$$
\begin{aligned}
& \text { meio tom menor }(25 / 24) \cong 18 \text { savarts; } \\
& \text { meio tom maior }(16 / 15) \cong 28 \text { savarts; } \\
& \text { limma grega }(256 / 243) \cong 23 \text { savarts }(\text { DANIÉLOU, } 1995, \text { p. } 20)
\end{aligned}
$$

\footnotetext{
${ }^{59}$ Therefore, in judging the possibilities and the value of musical systems, we should not trust the prejudiced judgement of our ears, but consider in their most abstract form their theoretical possibilities.

${ }^{60}$ Daniélou escreve em seu livro os nomes das notas no sistema anglo-saxão e com seus correspondentes indianos: C-Sa, D-Re, E-Ga, F-Ma, G-Pa, A-Dha, B-Ni.

${ }^{61}$ If we take the logarithm (base 10) of the frequency ratio and, for convenience, multiply by one thousand, we shall the interval expressed in terms of the unit known as the savart.
} 
Daniélou justifica sua preferência pela medida em savarts da seguinte maneira:

O sistema americano ${ }^{62}$, que é cada vez mais amplamente utilizado, divide o meio tom temperado em 100 partes para chegar em uma unidade conhecida como cent, a oitava é assim dividida em 1200 cents Este sistema tem alguns defeitos. Se queremos usar logaritmos para determinar a relação frequencial de um intervalo, é tentador simplesmente dividir o número de cents no intervalo por quatro. Infelizmente, isso dá uma resposta incorreta, uma vez que a oitava é, assim, dividida em 300 partes, em vez de 301. O principal defeito do cent, no entanto, é que a sua definição baseia-se na escala temperada, o que sempre leva a erros e não permite que a verdadeira natureza dos intervalos seja compreendida. ${ }^{63}$ (Daniélou, 1995, p. 20)

Daniélou toma como referência três intervalos: o tom maior $\left(\frac{9}{8}\right)$, o tom menor $(10 / 9)$ e o meio tom maior $(16 / 15)$ e por meio da combinação entre eles, que resultam de suas somas e diferenças, chega aos seguintes resultados: o tom maior divide-se em nove intervalos, o tom menor em oito intervalos e o meio tom maior em cinco intervalos. Estes intervalos são de uma coma sintônica $\left({ }^{81} / 80\right)$ que é de aproximadamente 5 savarts, exceto por uma descontinuidade de 8 savarts entre notas de nomes diferentes. Se dividirmos estes oito savarts por dois teremos os intervalos de quarto de tom $(1 / 4)$ e de três quartos de tom $(3 / 4)$ distante dos sons adjacentes em menos de uma coma (DANIÉLOU, 1995, p. 21).

Daniélou adota então o seguinte sistema de notação (DANIÉLOU, 1995, p. 21-23):

$\mathrm{O}$ sinal + indica que a nota foi elevada em uma coma $\left({ }^{81} / 80 \cong 5\right.$ savarts $)$ :

$$
\mathrm{D}+(\mathrm{Re}+)
$$

O sinal ++ indica que a nota foi elevada em duas comas ( $\cong 10$ savarts $)$ :

$$
\mathrm{D}++(\mathrm{Re}++)
$$

O sustenido sobrescrito indica que a nota foi elevada em meio tom menor $\left({ }^{25} / 24 \cong 18\right.$ savarts). Como foi ultrapassada a descontinuidade de 8 savarts a nota deixa de ser chamada

\footnotetext{
${ }^{62}$ Daniélou comete aqui um erro, pois o cent, que divide a oitava em 1200 unidades iguais, correspondendo cada intervalo de semitom a 100 cents, "foi introduzido por Ellis em 1885" (DUFFIN, 2007, p. 115). Como nos informa Duffin, na pequena biografia de Ellis em seu livro, Alexander J. Ellis nasceu em Hoxton próximo a Londres em 1814 e viveu até 1890, sendo, portanto, inglês e não americano. Ellis era filólogo e matemático mais conhecido como o historiador da altura do som, autor do livro On the History of Musical Pitch (1880) [Sobre a história da altura do som musical], e "tradutor da obra seminal de Hermann von Helmholtz sobre acústica musical, Die Lehre von den Tonempfindungen als physiologische Grundlage für die Theorie der Musik (1863)" (DUFFIN, 2007, p. 105), publicada em 1885 com o título On the Sensations of Tone as a Physiological Basis for the Theory of Music.

${ }^{63}$ The American system, which is more and more widely used, divides the tempered half tone into 100 parts to give a unit known as the cent; the octave is thus divided into 1,200 cents. This system has certain defects. If we wish to use logarithms to ascertain the frequency ratio of an interval, it is tempting simply to divide the number of cents in the interval by four. Unfortunately this gives an inaccurate answer, since the octave is thereby divided into 300 parts instead of 301. The main defect of the cent, however, is that its definition is based on the tempered scale, which always brings errors and does not allows the true nature of intervals to be understood.
} 
de $\mathrm{D}$ e passa a ser chamada $\mathrm{D} \#$ ou $\mathrm{E}$ ):

$$
\mathrm{D} \#^{\sharp}=\mathrm{E} b^{*}(\mathrm{Ga} \sharp)(\text { ati-komal })
$$

O sinal L- indica que a nota grave é elevada em uma limma $\left({ }^{256} / 243 \cong 23\right.$ savarts $)$, ou que a nota aguda é abaixada em um semitom maior $(16 / 15 \cong 28$ savarts $)$ :

$$
\mathrm{C} \sharp^{\mathrm{L}-}=\mathrm{D}{ }^{\mathrm{L}-}(\mathrm{ReL}-) \text { (komal) }
$$

O sinal L+ indica que a nota grave é elevada em um semitom maior $(16 / 15 \cong 28$ savarts) ou que a nota aguda é abaixada em uma limma $(256 / 243 \cong 23$ savarts $)$ :

$$
\mathrm{C} \sharp^{\mathrm{L}+}=\mathrm{D} b^{\mathrm{L}+}(\mathrm{ReL}+) \text { (komal) }
$$

No tom menor L+ e L- são iguais por isso indica-se apenas L:

$$
\mathrm{D} \sharp^{\mathrm{L}}=\mathrm{E} b^{\mathrm{L}}(\mathrm{GaL})(\text { komal) }
$$

O bemol sobrescrito indica que a nota aguda foi abaixada em um semitom menor $(25 / 24$ $\cong 18$ savarts $)$ ou que a nota grave foi elevada em um semitom maior $(16 / 15 \cong 28$ savarts $)$ no tom menor, ou em um semitom grande $\left({ }^{27} / 25 \cong 33\right.$ savarts $)$ no tom maior:

$$
\mathrm{D} \#^{\prime}=\mathrm{E} b^{\prime}(\mathrm{Ga} \downarrow) \text { (komal) }
$$

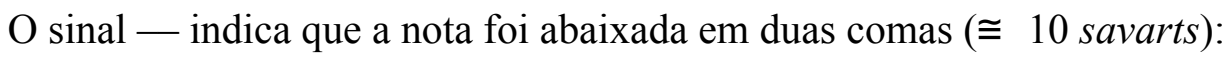

$$
\mathrm{D}-(\mathrm{Re}-)
$$

O sinal - indica que a nota foi abaixada em uma coma $\left({ }^{81} / 80 \cong 5\right.$ savarts $)$ :

$$
\mathrm{D}-(\mathrm{Re}-)
$$

Entre $++\mathrm{e} \#$ adiciona-se o sinal de quarto de tom $(1 / 4)$ e entre $b$ e - adiciona-se o sinal de três quartos de tom $(3 / 4)$.

A ordem de sucessão dos sinais para a notação dos intervalos fica então a seguinte:

Tom maior:

$\mathrm{A}($ Dha $) \quad+\quad++\quad 1 / 4 \quad \# \quad \mathrm{~L}-\quad \mathrm{L}+\quad$ b $\quad 3 / 4 \quad-\quad-\quad \mathrm{B}$ (ni)

Tom menor:

$\mathrm{D}(\mathrm{Re}) \quad+\quad++\quad \frac{1}{4} \quad \begin{array}{llllllllll} & + & \mathrm{L} & b & 3 / 4 & - & - & \mathrm{E}(\mathrm{Ga})\end{array}$

Meio tom diatônico:

$\begin{array}{llllllllll}\mathrm{E}(\mathrm{Ga}) & + & + & + & + & & 1 / 4 & - & & \end{array}$

$\mathrm{O}$ acidente que indica o nome da nota, como de costume, aparece ao lado da nota e a afinação exata é indicada pelos acidentes sobrescritos, porém na notação indiana indica-se 
apenas a afinação exata. Teríamos então:

$\mathrm{B} b^{\sharp}, \mathrm{B},{ }^{\mathrm{L}-}, \mathrm{B},{ }^{\mathrm{L}+}, \mathrm{B} b^{b}$, etc. (Ni $\sharp$ komal, NiL- komal, NiL+ komal, Ni b komal, etc.)

$A \#^{*}$ seria idêntico a $B b^{\sharp}, A \#^{L+}$ seria idêntico a $B b^{L+}, A \#{ }^{L-}$ seria idêntico a $B b^{\mathrm{L}-}$, e assim por diante.

A oitava é assim dividida em 53 intervalos (DANIÉLOU, 1995, p. 24).

Encontramos todas as possíveis relações intervalares na série harmônica, sendo assim, pode-se afirmar que todas as combinações melódicas ou harmônicas, estariam subentendidas na estrutura de um único som (DANIÉLOU, 1995, p. 25).

Todas as possíveis razões sonoras, sendo incluídas na série harmônica, podem ser representadas bastante naturalmente por uma relação de harmônicos. Verificamos assim que o tom maior C-D $(\mathrm{Sa}-\mathrm{Re})=9 / 8$ é o intervalo entre o oitavo e o nono harmônicos; o tom menor D-E $(\mathrm{Re}-\mathrm{Ga})=$ $10 \%$ é o intervalo entre o nono e o décimo harmônicos; o semitom menor, ${ }^{25} / 24$, é o intervalo entre o $24^{\circ}$ e o $25^{\circ}$ harmônicos, e assim por diante. O semitom temperado pode ser visto como o intervalo entre o $1.000 .000 .000^{\circ} \mathrm{e} o$ 1.059.463.094 ${ }^{\circ}$ harmônicos. ${ }^{64}$ (DANIÉLOU, 1995, p. 25-26)

Daniélou defende que quanto mais próximas da fundamental estiverem estas relações intervalares, melhor a apreciação humana e mais efetivos seus efeitos, pois estas relações possuem correspondência com as leis cósmicas (macrocosmo) e os aspectos fisiológicos dos seres humanos (microcosmo), permitindo que evoquem imagens e ideias que elas representariam em forma simplificada (DANIÉLOU, 1995, p. 26).

\subsection{4. $O$ ciclo de quintas: a teoria musical dos chineses}

Embora documentos chineses atestem que houve intercâmbio entre orquestras chinesas e indianas há aproximadamente 15 ou 20 séculos, o que indicaria uma possível origem comum entre as músicas de ambos os povos, suas tradições seguiram caminhos diferentes. A música chinesa baseia-se no sistema cíclico, ao contrário do sistema modal indiano em que cada nota se relaciona com uma tônica.

\footnotetext{
${ }^{64}$ All possible ratios of sounds, being included in the series of harmonics, can be represented quite naturally by a relation of harmonics. We thus find that the major tone C-D $(\mathrm{Sa}-\mathrm{Re})=9 / 8$ is the interval from 8 th to the 9 th harmonic; the minor tone D-E (Re-Ga) $=10 / 9$ is the interval from the 9 th to the 10 th harmonic; the minor half tone, ${ }^{25} / 24$, is the interval from the 24 th to the 25 th harmonic, and so on. The tempered half tone can be seen as the interval from the $1,000,000,000$ th to the $1,059,463,094$ th harmonic.
} 
Como para outros povos, a música para os chineses é a representação perceptível das relações que conectam os diferentes elementos materiais. Ao contrário dos indianos, a música não serviria para proporcionar uma união com o absoluto, a função da música chinesa é a de proporcionar uma harmonia no mundo material, em seus aspectos políticos, econômicos e sociais, que proporcionem um bom governo, além de contatos e relações entre aspectos aparentemente desconectados da manifestação material (DANIÉLOU, 1995, p. 30).

O livro que define os princípios metafísicos chineses é o I Ching, que segundo René Guénon foi escrito pelo imperador Fu Xi aproximadamente em 4000 a.C. (apud DANIÉLOU, 1995 , p. 31$)^{65}$. Nele encontramos a afirmação de que toda manifestação provém de dois princípios concordantes e suplementares: o princípio masculino yang - positivo, espiritual, ativo e quente - e o princípio feminino yin - negativo, material, passivo e frio, que seriam a base de toda a existência e que estariam presentes também na música.

Esta característica realista chinesa, que não ignora princípios abstratos, mas que os leva em consideração apenas quando encontram para eles aplicações práticas, foi o que levou a adotarem a escala pentatônica, embora conhecessem as possibilidades transcendentes da escala heptatônica:

Os antigos chineses certamente não ignoravam a transcendência da escala
heptatônica, que foi assimilada por eles aos "sete começos" ( $q i$ shi).
Entretanto, uma vez que eles concebiam a música apenas como um meio de
harmonizar os elementos da existência terrestre e estabelecer um balanço
entre espírito (céu) e matéria (terra), eles não deram muita atenção aos sete
graus, que formam a escala dos mundos transcendentais; ao contrário, eles
cultivaram à sua máxima potencialidade a ciência da escala pentatônica, que
simboliza as forças opostas do céu e da terra, do yang e do yin, mantidos em
equilíbrio no dualismo da existência. ${ }^{66}$ (DANIÉLOU, 1995, p. 33)

Portanto, a ideia evolucionista ${ }^{67}$ de que a escala pentatônica seria uma manifestação

\footnotetext{
${ }^{65} \mathrm{Cf}$. Guénon, 2012, p. 51 e 51 nota 15

${ }^{66}$ The ancient Chinese were certainly not ignorant of the transcendency of the heptatonic scale, which was assimilated by them to the "seven beginnings" (qi shi). However, since they conceived of music only as a means of harmonizing the elements of terrestrial existence and establishing a balance between spirit (heaven) and matter (earth), they did not pay much attention to the seven degrees, which form the scale of transcendental worlds; on the contrary, they cultivated to its utmost potentiality the science of the pentatonic scale, which symbolizes the opposing forces of heaven and earth, of yang and yin, held in equilibrium in the dualism of existence.

${ }^{67}$ Essa visão, típica do século XIX, começa a ser questionada e modificada a partir do início do Século XX. Thurston Dart afirma, condenando de maneira veemente, que, segundo esta ideia, que ele chama de teoria evolucionista da música, "o desenvolvimento da música seguiu um progresso constante em direção à sua perfeição presente” (DART, 2002, p. 27). Por sua vez, Joseph Kerman afirma que "o senso histórico da música e, concomitantemente, a reflexão intelectual ou acadêmica a respeito, a que se dá o nome de musicologia, estavam, no século XIX, estreitamente vinculados à ideologia nacionalista e religiosa" (KERMAN, 1987, p. 35).
} 
primitiva, da qual a escala heptatônica seria sua evolução ${ }^{68}$, ao menos no caso chinês, cai por terra. O fato de os chineses terem como prioridade as primeiras cinco notas do ciclo de quintas, que representam os cinco elementos, não significa que eles não conheciam ou não utilizavam os outros dois graus auxiliares.

A terra é simbolizada pelo número quatro, representado visualmente pelo quadrado, e é regulada por este número (quatro estações, quatro elementos, quatro direções no espaço, quatro castas, etc.). Porém estes quatro elementos têm origem num elemento celestial, o éter. Estes cinco elementos são representados em diversas culturas pela pirâmide, em que o cume é projetado no centro do quadrado. Da mesma maneira, a música para representar a harmonia entre céu e terra, mantém um centro, que é a nota gong, cercada por outras quatro notas.

Esta harmonia entre céu e terra, representada pela escala pentatônica seria, contudo, uma característica estática da influência celeste na terra. Para que exista uma influência no mundo em movimento, esta influência deve ser dinâmica e não estática, é preciso transformar o quadrado em círculo. A expressão deste movimento pelos sons submete-se então a uma lei cíclica que é aquela do ciclo das quintas (DANIÉLOU, 1995, p. 34-35).

Como vimos acima ${ }^{69}$, a fórmula do Tao Te King diz que "O um produziu o dois, o dois produziu o três, o três produziu todos os números" ${ }^{\text {"70 }}$. A quinta, representada pelo número três, seria então responsável pela formação da escala pentatônica por meio do ciclo de quintas. As notas desta escala seriam então:

\footnotetext{
${ }^{68}$ Podemos encontrar vestígios desta concepção evolucionista em Schoenberg que, embora não se refira especificamente e diretamente à escala pentatônica, no seu livro Harmonia (2001) afirma: "O descobrimento de nossa escala foi um feliz acaso para o desenvolvimento de nossa música. Não só pelos resultados obtidos, como também porque poderíamos ter encontrado outra sucessão diferente, como os árabes, os chineses, os japoneses ou os ciganos. O fato de a música deles não ter-se desenvolvido até a mesma altura da nossa não é, necessariamente, por consequência da imperfeição de suas escalas, mas pode dever-se à imperfeição de seus instrumentos [...]" (p. 64). No entanto, também nele encontramos afirmações que apontam já para o questionamento desta ideia, quando afirma: "O caminho da história, tal e qual se mostra nas dissonâncias mais usadas e correntes, não nos ajuda, neste caso, a avaliar precisamente a situação real, conforme o demonstram as escalas incompletas ou estranhas de diversos povos, os quais não obstante, poderiam seguramente invocar uma relação com a natureza. Talvez seus sons sejam mais naturais (ou seja: mais exatos, mais justos, melhores) que os nossos, pois o sistema temperado - qual é somente um expediente para dominar as dificuldades materiais - tem pouca semelhança com a natureza. Talvez seja, o nosso sistema, mais vantajoso, mas não superior" (p. 59-60).

É sintomática ainda a afirmação que Schoenberg atribui ao Dr. Robert Neumann, extraída de uma longa nota de rodapé: "A moda dos últimos anos - opor à cultura européia a dos povos mais antigos, orientais e exóticos - parece querer estender-se também à música" (SCHOENBERG, 2001, p. 65n). Lembramos que Harmonia de Schoenberg foi publicada originalmente em 1911 e a primeira versão de Music and the power of sound, de Daniélou, com o título Introduction to the Study of Musical Scales teve sua primeira edição em 1943, aproximadamente trinta anos, o que contribui também para a abordagem diferente entre as duas obras.

${ }^{69}$ Ver notas 50 e 52.

${ }^{70}$ One has produced two, two has produced three, three has produced all the numbers.
} 


\begin{tabular}{|c|c|c|c|c|c|}
\hline $\mathrm{I}$ & III & V & II & IV & I \\
\hline $\mathrm{C}(\mathrm{Sa})$ & $\mathrm{D}(\mathrm{Re})$ & $\mathrm{E}+(\mathrm{Ga}+)$ & $\mathrm{G}(\mathrm{Pa})$ & $\mathrm{A}+(\mathrm{Dha}+)$ & $\mathrm{C}(\mathrm{Sa})$ \\
\hline
\end{tabular}

Tabela 1: Notas da escala pentatônica.

Às quais se acrescentariam dois sons auxiliares:

\begin{tabular}{|c|c|c|c|c|c|c|c|}
\hline $\mathrm{I}$ & III & V & VII & II & IV & VI & I \\
\hline $\mathrm{C}(\mathrm{Sa})$ & $\mathrm{D}(\mathrm{Re})$ & $\mathrm{E}+(\mathrm{Ga}+)$ & $\mathrm{F}^{\mathrm{L}+}(\mathrm{MaL}+)$ & $\mathrm{G}(\mathrm{Pa})$ & $\mathrm{A}+(\mathrm{Dha}+)$ & $\mathrm{B}+(\mathrm{Ni}+)$ & $\mathrm{C}(\mathrm{Sa})$ \\
\hline
\end{tabular}

Tabela 2: Notas da escala pentatônica acrescidas de duas notas auxiliares.

Estas duas notas auxiliares não podem servir como tônicas pois pertencem aos mundos invisíveis, além de sua afinação nos parecer imprecisa. A nota número VII (Fá\# ${ }^{\mathrm{L}+}$ ), [trítono] tanto ascendente como descendentemente representa o limite da consonância também na música modal, assim como significava o diabolus in musica na Idade Média.

As próximas cinco notas neste ciclo de quintas são:

\begin{tabular}{|c|c|c|c|c|c|}
\hline VIII & IX & X & XI & XII & XIII \\
\hline $\mathrm{D} b^{\prime}($ Re komal $)$ & $\mathrm{A} b^{\prime}($ Dha komal $)$ & $\mathrm{E} b^{\prime}(\mathrm{Ga}$ komal $)$ & $\mathrm{B} b^{\prime}(\mathrm{Ni}$ komal $)$ & $\mathrm{F}+(\mathrm{Ma}+)$ & $\mathrm{C}+(\mathrm{Sa}+)$ \\
\hline
\end{tabular}

Tabela 3: cinco notas restantes no ciclo de quintas, e a décima terceira.

A décima terceira nota, nos traz de novo à fundamental, porém elevada em uma coma, $\left(3^{12} / 2^{19}={ }^{531.441} / 524.288=5,88\right.$ savarts ou $\cong 2$ cents $)$ por isso a notação $\mathrm{C}+(\mathrm{Sa}+)$.

Caso continuemos o ciclo de quintas, teremos mais 12 quintas todas elevadas em uma coma em relação às anteriores, e nossa $24^{\mathrm{a}}$ quinta (nota 25) seria duas comas acima de nossa primeira nota: $\mathrm{C}++(\mathrm{Sa}++)$ e assim sucessivamente até a $53^{\mathrm{a}}$ quinta (nota 54) que se insere entre a oitava $\mathrm{C}(\mathrm{Sa})$ e a $12^{\mathrm{a}}$ quinta Dó $+(\mathrm{Sa}+)$. O próximo ciclo completa-se na $359^{\mathrm{a}}$ quinta (nota 360) e o seguinte na nota 666. No entanto, por razões simbólicas e musicais, os chineses avançam apenas até a $60^{\mathrm{a}}$ nota, o que coloca as sete notas seguintes, a partir da $53^{\mathrm{a}}$ quinta (nota 54), acima daquelas da escala inicial de sete graus. "A razão dada é que 12 (número de cada ciclo $) \times 5$ (número de elementos $)=60^{\prime, 71}($ DANIÉLOU, 1995, p. 37)

As notas do ciclo de quintas são consideradas alternadamente masculinas (yang) e

\footnotetext{
${ }^{71}$ The reason given is that 12 (number of each cycle) $\times 5$ (number of elements) $=60$
} 
femininas (yin): C (Sa) - yang; G (PA) - yin; D (Re) - yang e assim por diante.

Os chineses constroem tubos de metal precisamente afinados nas sessenta notas da escala, que são chamados $L \ddot{u}$. Para cada nota tomada como tônica, outras quatro são possíveis de ser encontradas a partir deste conjunto de sessenta tubos.

Abaixo, as correspondências simbólicas dos graus da escala pentatônica:

\begin{tabular}{|c|c|c|c|c|c|c|c|c|}
\hline Grau & Nota & Cor & Direção & Elemento & Estação & Números & Função & Animal e qualidade \\
\hline $\begin{array}{c}\text { gong } \\
\text { fundamental }\end{array}$ & $\mathrm{C}(\mathrm{Sa})$ & amarelo & centro & terra & & 5 & $\begin{array}{c}\text { imperador } \\
\text { e príncipe }\end{array}$ & espécies nuas \\
\hline $\begin{array}{c}\text { shang } \\
\text { segunda } \\
\text { maior }\end{array}$ & $\mathrm{D}(\mathrm{Re})$ & branco & oeste & metal & outono & $9 \mathrm{e} 4$ & ministros & $\begin{array}{c}\text { espécies peludas } \\
\text { (o tigre branco do oeste) } \\
\text { som metálico, firme e rígido } \\
\text { intolerável para os espíritos }\end{array}$ \\
\hline $\begin{array}{c}\text { jiao } \\
\text { terça maior }\end{array}$ & $\mathrm{E}+(\mathrm{Ga}+)$ & azul & leste & madeira & primavera & $8 \mathrm{e} 3$ & povo & $\begin{array}{c}\text { espécies com escamas ou aquáticas } \\
\text { (o dragão azul do mar do leste) }\end{array}$ \\
\hline $\begin{array}{c}z h i \\
\text { quinta }\end{array}$ & $\mathrm{G}(\mathrm{Pa})$ & vermelho & sul & fogo & verão & $7 \mathrm{e} 2$ & $\begin{array}{c}\text { serviços } \\
\text { públicos }\end{array}$ & $\begin{array}{c}\text { espécies emplumadas } \\
\text { (o pássaro vermelho do sul) }\end{array}$ \\
\hline $\begin{array}{c}Y u \\
\text { sexta }\end{array}$ & $\mathrm{A}+(\mathrm{Dha}+)$ & preto & norte & água & inverno & $6 \mathrm{e} 1$ & produtos & $\begin{array}{c}\text { espécies com carapaças } \\
\text { (a tartaruga negra do norte) }\end{array}$ \\
\hline
\end{tabular}

Tabela 4: correspondências simbólicas dos graus da escala pentatônica chinesa (DANIÉLOU, 1995, p. 52).

\subsubsection{Relações com uma tônica: a música modal da Índia}

A teoria musical indiana parte de princípios metafísicos que regem todos os aspectos da criação do mundo. A partir da análise e classificação de todas as possibilidades de razões intervalares e relações sonoras, desenvolveram um número astronômico de combinações teoricamente possíveis, das quais apenas algumas são utilizadas na prática, mas que são acessíveis aos músicos que sentirem necessidade de sua utilização.

Os indianos consideram dois tipos de músicas regidos por dois tipos de teorias. Uma teoria baseada em princípios metafísicos comuns às leis de criação universal e à criação sonora e outra baseada no uso empírico de princípios físicos. "A primeira abordagem é chamada pelos indianos de mārga (direcional) e, sendo baseada em leis absolutas, é universal e imutável, enquanto a outra, que é chamada deśī (regional), varia infinitamente de acordo com o lugar e tempo.”72 (DANIÉLOU, 1995, p. 59)

A música ritual e sagrada segue a teoria mārga (direcional), e acredita-se que ela tenha

\footnotetext{
${ }^{72}$ The first approach is called by the Indians mārga (directional) and, being based on absolute laws, is universal and unchangeable, while the other, which is called deśī (regional), varies endlessly according to place and time.
} 
influência em todas as coisas vivas e inanimadas, influenciando e evocando imagens, emoções e sentimentos. Já a música deśī (regional), é aquela que se baseia apenas no prazer e na expressão de sentimentos e paixões humanas, e por isso varia bastante de acordo com o tempo e lugar. Sua influência pode ser boa ou má e só pode ser avaliada em relação à teoria mārga (DANIÉLOU, 1995, p. 59).

A escala indiana é formada por sete notas principais, chamadas de svaras, e duas secundárias. As sete principais relacionam-se com sete planetas e as secundárias com os $\operatorname{nodos}^{73}$ da lua. Estas nove notas relacionam-se com os nove grupos de consoantes do alfabeto hindu. "Estes sons colocam-se, de acordo com os modos, nas doze regiões da oitava, assim com os nove grupos de consoantes associam-se com as 12 vogais, ou os planetas com os doze signos do zodíaco"74 (DANIÉLOU, 1995, p. 64).

As sete notas principais, ou svaras, são chamadas: Shadja (nascida de seis), Rishabha (touro), Gāndhāra (agradável aos seres celestiais), Madhiamā (som médio), Pañchama (quinta nota), Dhaivata (enganadora), e Nishāda (sentada). Na prática elas são chamadas mais resumidamente: $\mathrm{Sa}, \mathrm{Re}, \mathrm{Ga}$, $\mathrm{Ma}, \mathrm{Pa}, \mathrm{Dha}, \mathrm{Ni}$. As duas svaras acessórias são chamadas antara-Ga (Ga intermediária), e kākalī-Ni (Ni agradável). ${ }^{75}$ (DANIÉLOU, 1995, p. 64)

A nota mais grave da escala Sa, atualmente é a nota considerada como tônica, no entanto, em livros antigos a nota que era considerada tônica era a quarta nota Ma, que corresponde à mesē dos gregos. A tônica é a única nota que não deve ser modificada ou suprimida (DANIÉLOU, 1995, p. 65).

\footnotetext{
73 “O movimento de translação da Terra em torno do Sol define um plano ao qual se dá o nome de eclíptica. Com a excepção de Plutão, todos os outros planetas têm o seu movimento de translação praticamente sobre a eclíptica. [...]

O movimento de translação da Lua em torno da Terra efectua-se num plano que faz um ângulo de aproximadamente $5^{\circ}$ com o plano da eclíptica. Da intersecção destes dois planos define-se a 'linha dos nodos'. Assim, os nodos lunares são as intersecções da órbita da Lua com a eclíptica: nodo ascendente (ou nodo Norte) quando a Lua efectua o seu movimento de Sul para Norte da eclíptica e nodo descendente (ou nodo Sul) quando este movimento tem o sentido de Norte para Sul.

A antiga tradição acreditava que um eclipse era provocado por um dragão que devorava o corpo celeste (Sol ou Lua) e que o vomitava em seguida. A cabeça e a cauda desse dragão são a denominação que então se dava aos nodos lunares: a cauda do dragão seria o nodo Sul (४) e a cabeça do dragão seria o nodo Norte (८). De facto, os eclipses estão intimamente ligados a esse dragão imaginário, já que se a Lua Nova ocorre enquanto a Lua se encontra sobre a sua cauda (o nodo Sul), há um eclipse do Sol, enquanto que se a Lua Cheia ocorre enquanto a Lua se encontra sobre a sua cabeça (o nodo Norte), há um eclipse da Lua" (SIMÕES; FERNANDES, 2000).

${ }^{74}$ These sounds place themselves, according to modes, into the twelve regions of the octave, just as the nine groups of consonants associate themselves with the twelve vowels, or the planets with the twelve signs of the zodiac.

${ }^{75}$ The seven principal notes, or svaras, are called: Shadja (born of six), Rishabha (bull), Gāndhāra (pleasing to celestial beings), Madhiamā (middle sound), Pañchama (fifth note), Dhaivata (deceitful), e Nishāda (seated). In practice they are called more briefly: $\mathrm{Sa}, \mathrm{Re}, \mathrm{Ga}, \mathrm{Ma}, \mathrm{Pa}$, Dha, Ni. The two accessory svaras are named antara-Ga (intermediate $\mathrm{Ga}$ ), and kākali-Ni (pleasing Ni).
} 
Com estas duas tônicas é possível formar duas escalas (grāma) diatônicas diferentes, sendo que a diferença entre elas se dá pela afinação da nota Dha (A). Na $S a$ grāma, a nota é elevada em um śruti ${ }^{76}$ sendo portanto A+ (Dha+), enquanto na Ma grāma a nota da escala é A (Dha).

A respeito da escala enarmônica hindu que possui 22 śrutis, Daniélou cita Bhārata que no tratado teórico indiano Natya-śāstra explica que

o método empregado para obter esta escala consiste em afinar dois instrumentos idênticos (vīnas) em $S a$ grāma. Então, adaptando um deles ao Ma grāma com a ajuda da diferença entre as quartas justas E A (Ga Dha) e $\mathrm{A}+\mathrm{D}(\mathrm{Dha}+\mathrm{Re}),[\ldots]$ o $\mathrm{A}+(\mathrm{Dha}+)$ é abaixado uma coma para Dha. Se mantivermos este novo A (Dha) como um som fixo e reafinar o instrumento em Sa grāma, todas as notas deste instrumento serão uma coma mais baixa do que aquelas do primeiro instrumento. As notas combinadas dos dois instrumentos então dá a escala de 22 śrutis. ${ }^{77}$ (DANIÉLOU, 1995, p. 73-74)

Daniélou explica que do ponto de vista acústico, a divisão da oitava em doze semitons é chamada de divisão de primeira ordem, a divisão em $53^{78}$ comas é chamada de divisão de segunda ordem. Ao se eliminar desta divisão de segunda ordem, de doze em doze notas, as menos empregadas na prática, as 53 notas originais são reduzidas primeiro a 41 depois a 29 e finalmente a 17 notas, que é a divisão básica da oitava empregada pelos árabes.

A $54^{\text {a }}$ nota divide a coma ao meio, e se utilizarmos esta meia coma para dividirmos a oitava chegamos à divisão de terceira ordem que divide a oitava em 358 intervalos. Fazendo o mesmo processo acima, de redução das notas menos importantes, chega-se aos 22 intervalos, ou śrutis, empregados pelos indianos (DANIÉLOU, 1995, p. 74-75)

Daniélou explica que os teóricos da música indiana preferem definir os intervalos pelo seu sentimento do que por números, e esta definição depende da posição desta nota em relação à sua tônica. Ele também explica que este fenômeno pode ser percebido pelos músicos ocidentais, quando identificam determinada nota como sendo "mais escura" do que outra da mesma altura, segundo ele, tal diferença se deve à altura da nota e não ao seu timbre, de modo que se atribui uma diferença no parâmetro da altura a uma característica tímbrica

\footnotetext{
${ }^{76} \mathrm{Na}$ escala existem 22 śrutis que equivalem a aproximadamente uma coma sintônica ${ }^{81} / 80$.

${ }^{77}$ The method employed to obtain this scale consists in tuning two identical instruments (vīnas) in the Sa grāma. Then, by adapting one of them to the Ma grāma with the help of the difference between the perfect fourths $E$ $A(G a D h a)$ and $A+D(D h a+R e),[\ldots]$ the $A+(D h a+)$ is lowered by one comma to A (Dha). If we then keep this new A (Dha) as a fixed sound and retune the instrument in the Sa grāma, all the notes of this instrument will be one comma lower than those of the first instrument. The combined notes of two instruments then give the scale of twenty-two śrutis.

${ }^{78}$ Schoenberg, em Harmonia, cita numa nota de rodapé o Dr. Robert Neumann que defende a divisão da oitava em 53 partes, porém igualmente temperada (SCHOENBERG, 2001, p. 64n-66n).
} 
(DANIÉLOU, 1995, p. 78-79).

Os 22 śrutis são divididos em cinco famílias, chamadas jātis, de acordo com seu caráter. São elas: Dīpta (brilhante, ilustre); Mridub (leve); Ayata (abundante); Madhya (moderado); Karunā (compassivo).

O rāga ${ }^{79}$ é um termo indiano que significa mais do que o termo modo como estamos acostumados no ocidente, ele implica uma escala ascendente e outra descendente, bem como características melódicas específicas. Ele é definido por quatro fatores indispensáveis:

1. Uma tônica constantemente tocada, como um pedal ou bordão;

2. Uma escala contendo entre cinco e nove notas, normalmente com aspectos diferentes ascendente e descendentemente;

3. Certas figuras melódicas e modos de ataque, responsável pela forma (rūpa) do rāga;

4. Uma dominante, uma nota (que eventualmente pode ser a própria tônica, mas não necessariamente) que é tocada com mais frequência que as outras.

Estes quatro elementos são suficientes para definir o sentimento do rāga, que normalmente se mantém o mesmo durante toda a execução. Os tratados clássicos descrevem 72 răgas $^{80}$ principais dos quais derivam algumas centenas ${ }^{81}$ (DANIÉLOU, 1995, p. 89).

Os rāgas são classificados e tocados de acordo com três principais divisões do dia, pois os indianos acreditam que o estado de espírito do ser humano muda durante o dia, que representa uma imagem reduzida do ciclo da vida. Esses três períodos são:

1. O dia, iluminado pelo sol;

2. A noite, iluminada pela lua;

3. O crepúsculo, iluminado pelo fogo.

Tanto o dia como a noite possuem um período masculino, ascendente e um período feminino, descendente (DANIÉLOU, 1995, p. 90).

\subsubsection{Confusão dos sistemas: a música dos gregos}

Segundo Daniélou, ao contrário da crença comumente difundida de que os gregos inventaram tudo, no caso da música grega antiga eles receberam os elementos de seu sistema

\footnotetext{
${ }^{79}$ Entre as várias traduções desta palavra encontramos paixão, cor e aroma.

${ }^{80}$ Esta classificação é usada no sul da Î́ndia e são chamadas de mela-s ou melakartā-s (DANIÉLOU, 2003c, p. 57)

${ }^{81}$ Para mais informações sobre rāgas (cf. DANIÉLOU, 2003c)
} 
musical dos egípcios e do oriente próximo. A originalidade de sua teoria musical vem dos físicos que tentaram explicar as leis de seu sistema com ajuda de um aparato teórico aplicável a outro sistema (DANIÉLOU, 1995, p. 94).

O aspecto modal da música grega poderia ser explicado pela teoria da música modal indiana, enquanto seu aspecto cíclico e modulatório, explicado pela doutrina pitagórica do número, seria representado de forma mais completa pela teoria chinesa.

A música ocidental herdou este aspecto ambíguo da música grega antiga, e só por tal herança a música grega necessita ser estudada, pela sua inadequação entre dois sistemas. Frequentemente a música grega antiga é melhor entendida pela crítica feita pelos físicos aos músicos práticos, pois seria em sua prática, em desacordo com sua teoria, que se poderia observar os vestígios de sua herança (DANIÉLOU, 1995, p. 95).

Outro aspecto relevante sobre a música grega antiga é o fato de que não apenas os europeus ocidentais herdaram seu sistema, mas também árabes e turcos. Inclusive grande parte dos tratados musicais e mesmos filosóficos gregos chegaram à Europa através dos árabes. Teóricos como al-Fārābī no século X e Avicenna um pouco depois, escreveram sérios tratados sobre música grega. Poder-se-ia deduzir então, que a maneira mais confiável de entender a música grega antiga seria por meio do estudo da música árabe, que teria se mantido mais próxima desta tradição do que por meio de reconstruções baseadas apenas nos tratados teóricos.

Apesar das diversas teorias e teóricos da música grega, Daniélou se concentra no estudo daquela teoria comumente conhecida como pitagórica e no que nela se elabora a respeito dos modos e das classificações musicais gregas, procurando entender na teoria grega pitagórica as particularidades de seu aspecto modal ao invés de tentar encontrar os princípios da harmonia nos modos gregos (DANIÉLOU, 1995, p. 96-97).

Para tal empreitada, Daniélou afirma que é possível resumir a teoria pitagórica de acordo com o que encontramos neste trecho do diálogo Timeu de Platão, referente à divisão da alma do mundo:

[...] já o deus, graças à sua condição e virtude, constituiu a alma anterior ao corpo e mais velha do que ele, para o dominar e governar - sendo ele o governado - a partir dos seguintes recursos e do modo que se expõe: entre o ser indivisível, que é imutável, e o ser divisível que é gerado nos corpos, misturou uma terceira forma de ser feita a partir daquelas duas. E quanto à natureza do Mesmo e do Outro, estabeleceu, de igual modo, uma outra natureza entre o indivisível e o divisível dos seus corpos. Tomando as três naturezas, misturou-as todas numa só forma e pela força harmonizou a natureza do Outro - que é difícil de misturar - com o Mesmo. Procedendo à 
mistura de acordo com o ser, formou uma unidade a partir das três, e depois distribuiu o todo por tantas partes quantas era conveniente distribuir, sendo cada uma delas uma mistura de Mesmo, de Outro e de ser. Então, começou a dividir do seguinte modo: em primeiro lugar, retirou uma parte do todo; em seguida, retirou outra que era o dobro da primeira; uma terceira, que corresponde a uma vez e meia a segunda e ao triplo da primeira; uma quarta, que era o dobro da segunda; uma quinta, o triplo da terceira; uma sexta, oito vezes a primeira; e uma sétima, que corresponde a vinte e sete vezes a primeira. (PLATÃO, 2011, 35b-c)

Tal divisão nos dá a seguinte progressão numérica: 1, 2, 3, 4, 9, 8 e 27. Esta progressão pitagórica pode ser encontrada em todo sistema tradicional, inclusive com sua inversão entre o quinto e sexto número. É a escala base na qual o Sāmaveda é cantado, e em notação moderna pode ser a seguinte escala descendente: G F E D B C A.

Segundo Daniélou, ao tomarmos os números dessa relações dois a dois temos seis intervalos e doze relações: $1 / 2-2 / 1,2 / 3-3 / 2,3 / 4-4 / 3,4 / 9-9 / 4,9 / 8-8 / 9,8 / 27-27 / 8$. Porém é necessário unificar esses intervalos preenchendo os espaços entre eles. Vemos então no Timeu:

Depois disto, preencheu os intervalos duplos e triplos, subtraindo partes da mistura inicial e colocando-as entre as outras, de tal forma que cada intervalo tivesse dois centros: um que transpõe um dos extremos e é transposto pelo outro na mesma fracção, e outro que transpõe o extremo que lhe é numericamente idêntico e também ele é transposto. Destas ligações foram gerados nos intervalos atrás referidos outros intervalos de um e meio, um e um terço e um e um oitavo. Através do intervalo de um e um oitavo, preencheu todos os de um e um terço e deixou uma parte de cada um deles, tendo este intervalo sobrante sido definido pela relação entre o número duzentos e cinquenta e seis e o número duzentos e quarenta e três. (PLATÃO, 2011, 35c-36b)

Desta maneira, temos o intervalo entre 1 e 2 preenchidos com a média aritmética $3 / 2-$ "um e meio"; com a média harmônica $4 / 3$ - "um e um terço"; e ainda o intervalo $9 / 8$ - "um e um oitavo". Este último preenche o intervalo de $4 / 3$ de maneira que sobre uma parte definida pelo intervalo $256 / 243$. Esta operação é resultado da seguinte expressão: $9 / 8 \times 9 / 8 \times 256 / 243=4 / 3$. Estas relações nomeiam os seguintes intervalos: quinta justa $\frac{3}{2}$; quarta justa $4 / 3$; tom inteiro pitagórico $9 / 8$ e limma (meio tom pitagórico) $256 / 243$.

$\mathrm{Na}$ antiga Grécia os sons que chamamos de agudos eram graves e vice-versa. Daí decorre que a sequência formada pelas razões intervalares formaria numa interpretação moderna, uma escala ascendente:
1
$9 / 8$
$81 / 64$
$4 / 3$
$3 / 2$
$27 / 16$
$256 / 243$
C (Sa)
$\mathrm{D}(\mathrm{Re})$
$\mathrm{E}+(\mathrm{Ga}+)$
F (Ma)
$\mathrm{G}(\mathrm{Pa})$
$\mathrm{A}+$ (Dha)
$\mathrm{B}+(\mathrm{Ni}+)$
$\mathrm{C}(\mathrm{Sa})$ 
No entanto, na interpretação antiga seria uma escala descendente. Para essa escala descendente é necessário pensar nas razões de comprimento da corda, começando da metade da corda para a corda inteira, dividindo cada razão da série pitagórica por dois:

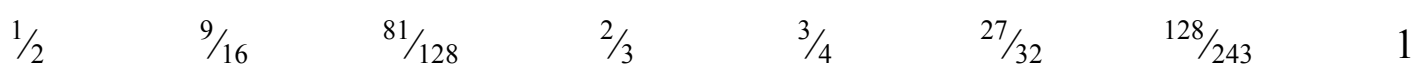

O que nos dá as seguintes razões de frequências:

$\begin{array}{cccccccc}2 & 16 / 9 & 128 / 81 & 3 / 2 & 4 / 3 & 32 / 27 & 243 / 128 & 1 \\ \mathrm{C}(\mathrm{Sa}) & \mathrm{B},{ }^{\mathrm{L}+}(\mathrm{NiL}+) & \mathrm{A},{ }^{\mathrm{L}}(\mathrm{DhaL}) & \mathrm{G}(\mathrm{Pa}) & \mathrm{F}(\mathrm{Ma}) & \mathrm{E} b{ }^{\mathrm{L}}(\mathrm{GaL}) & \mathrm{D},{ }^{\mathrm{L}-}(\mathrm{ReL}-) & \mathrm{C}(\mathrm{Sa})\end{array}$

Nota-se nas duas escalas acima que elas são formadas por dois tetracordes separados por um tom maior, sendo cada tetracorde formado por dois tons maiores e uma limma. No primeiro caso, a escala ascendente forma o que se chama modernamente de escala maior, ou modo Jônico. No segundo caso, a escala descendente forma a sequência de notas que é modernamente chamada de modo Frígio, porém este modo na Grécia antiga era chamado de modo Dórico.

Ao contrário do pensamento moderno, em que um modo é definido pelas posições de suas notas dentro de uma oitava, para os gregos antigos - assim como hoje para os árabes e turcos - um modo era definido pelas posições das notas dentro de um quadro formado por quatro tetracordes. Desta maneira, uma melodia transposta oitava acima teria seu caráter mudado, restaurando seu caráter apenas após uma transposição de duas oitavas acima.

O quadro de tetracordes é fixo e formado pela tônica, a quarta e a quinta, que são invariáveis, e que Aristóteles definia como o "corpo da harmonia". Dentro destes tetracordes as notas são móveis e suas diferentes posições formam os gêneros diatônico, cromático e enarmônico (DANIÉLOU, 1995, p. 99).

Segundo Daniélou, mesēe é a nota ao redor da qual os tetracordes gravitam, é dedicada ao Sol por ser o centro de todo o sistema, a nota mais aguda do tetracorde central (DANIÉLOU, 1995, p. 100).

Os modos gregos eram divididos em três gêneros assim caracterizados:

1. Diatônico - cada tetracorde dividido em dois tons e um semitom;

2. Cromático - cada tetracorde possui uma terça menor e o tom restante dividido em dois semitons;

3. Enarmônico - cada tetracorde possui uma terça maior e o semitom remanescente 
dividido em dois quartos de tom.

Segundo al-Fārābī, o que caracteriza os gêneros não é a sequência de semitons, no caso do gênero cromático, nem a sucessão de quartos de tom, no caso do gênero enarmônico. Eles podem estar em sequência, mas esta é apenas uma das possibilidades, não é dessa sequência que depende a caracterização dos gêneros (DANIÉLOU, 1995, p. 102).

\subsubsection{A escala ocidental e o temperamento igual}

O sistema musical ocidental é o resultado de uma mistura caótica de várias definições teóricas. Ao mesmo tempo em que o sistema é cíclico, com constantes mudanças de tônicas resultantes de processos modulatórios, cada tônica, e mesmo cada nota de cada escala é acompanhada por um acorde que depende, para sua formação de características do sistema modal, baseado nas relações com uma tônica proporcionado pelo fenômeno da ressonância e pela série harmônica. O problema desta combinação é que as notas necessárias para tornar um acorde consonante são diferentes daquelas necessárias para a modulação (DANIÉLOU, 1995, p. 121).

Como tentativa de resolver tal problema, o ocidente pouco a pouco adotou de maneira generalizada o temperamento igual. O temperamento igual, ao distorcer os intervalos torna sua significação vaga e imprecisa. Daniélou concorda com a alegação de que a audição poderia reconhecer o verdadeiro intervalo, representado pelo intervalo temperado, mas observa que cada ouvinte faz adaptações individuais de acordo com tendências pessoais. Cada intervalo ou acorde teria diferentes significados, para diferentes pessoas, de acordo com seu estado de espírito. O resultado é que os ocidentais perdem cada vez mais toda a concepção de música capaz de expressar emoções, sentimentos ou as mais altas ideias (DANIÉLOU, 1995, p. 121-122).

As músicas que tentam representar determinados fenômenos por meio de imitação de objetos e animais e os ruídos por eles emitidos, segundo Daniélou, é considerado infantil para o modo de pensar oriental.

Por exemplo, quando o modo indiano das chuvas Megh-Mallar, é tocado, nenhum som tentará imitar o ruído de gotas de chuva ou de trovão, mas as relações entre os sons será similar àquelas entre os elementos quando um temporal está se aproximando que não apenas músicos treinados, mas 
mesmo animais sentirão inevitavelmente a chuva no ar. ${ }^{82}$ (DANIÉLOU, 1995, p. 123)

A progressiva simplificação teórica adotada pelo ocidente, para a realização de suas características harmônicas e polifônicas, afasta sua música dos princípios acústicos e das leis nas quais as correspondências metafísicas se baseiam, perdendo assim seu apelo evocatório (DANIÉLOU, 1995, p. 124).

Segundo Daniélou, a música ocidental começa já de maneira distorcida. O papa Gregório I, conhecido também como São Gregório Magno, ao trazer os oito modos do cantochão do oriente, quando de seu cargo de embaixador em Constantinopla, os transcreveu dos oito modos bizantinos utilizados pelo patriarca Severus de Antioquia, porém perdeu-se justamente aquilo que era fundamental para a definição de cada tom e a expressão de cada nota: o ison, o pedal que servia de sustentação para a expressão musical modal. Esta ausência torna o cantochão vago e etéreo, sem clareza em sua significação ${ }^{83}$ (DANIÉLOU, 1995, p. 125).

A escala de Zarlino, também conhecida como escala justa, carrega o problema de ser uma junção de dois sistemas, um ascendente, de característica cíclica, responsável pelas notas C, G, D e um descendente, de característica modal, responsável pelas notas E, A, B e F, formando a seguinte escala com suas razões de frequências:

$\begin{array}{cccccccc}\mathrm{C}(\mathrm{Sa}) & \mathrm{D}(\mathrm{Re}) & \mathrm{E}(\mathrm{Ga}) & \mathrm{F}(\mathrm{Ma}) & \mathrm{G}(\mathrm{Pa}) & \mathrm{A}(\mathrm{Dha}) & \mathrm{B}(\mathrm{Ni}) & \mathrm{C}(\mathrm{Sa}) \\ 1 & 9 / 8 & 5 / 4 & 4 / 3 & 3 / 2 & 5 / 3 & 15 / 8 & 2\end{array}$

O problema desta escala se dá quando se modula, pois de acordo com a nova tônica, diversas notas precisariam ter sua afinação elevada ou abaixada de maneira desigual, além dos bemóis começarem a se tornar mais graves que os sustenidos e vice-versa.

De acordo com a teoria indiana, esta escala, a escala maior adotada no ocidente

\footnotetext{
${ }^{82}$ For example, when the Indian mode of the rains, Megh-Mallar, is played, no sound will attempt to imitate the noise of raindrops or of thunder, but the relations between the sounds will be so similar to those between the elements when a storm is approaching that not only trained musicians but even animals will inevitably feel the rain in the air.

${ }^{83} \mathrm{~A}$ importância dada aqui por Daniélou ao papa Gregório Magno, atribuindo-lhe praticamente a criação da música ocidental a partir do canto gregoriano, deve-se a um erro muito comum, pois, como observa Françoise Ferrand, normalmente "o termo 'canto gregoriano' é aplicado erroneamente, por extensão abusiva, a toda forma de cantochão, quando, na verdade, não passa de um dos ramos de um tronco feito de múltiplas liturgias, as quais a reforma do papa Gregório I teve por objetivo afastar, numa tentativa de fazer adotar, pelo conjunto da cristandade, a nova liturgia romana" (FERRAND, 1997, p. 138). Entre essas liturgias a autora cita o rito romano antigo, o canto galicano, a liturgia moçárabe ou hispânica e a liturgia ambrosiana. Ferrand utiliza os termos rito, canto e liturgia como sinônimos (ibidem, p. 138-139). Daniélou não leva em consideração estes outros cantos, desprezando a riqueza da prática musical litúrgica da Idade Média.
} 
representa, em seus aspectos simbólicos e de correspondências emocionais, presunção, vaidade, materialismo e busca por prazer. Segundo Daniélou, ela só foi aceita na Índia em 1813, sob o nome de rāga Bilāval, proposta por Muhammad Rezza em seu Nagmat e asaphi; enquanto que foi introduzida no ocidente por Glareanus, em seu Dodecachordon, com o nome de modo Jônio - ou modus durum - em 1547 (DANIÉLOU, 1995, p. 129-130).

O temperamento igual, ao tornar todos os semitons iguais, torna a razão entre frequências distantes das razões mais simples que, segundo Daniélou, seriam responsáveis pelas evocações simbólicas, emocionais e de ideias, possíveis devido às suas correspondências metafísicas. Enquanto o semitom maior possui a razão $16 / 15$ e o semitom menor $25 / 24$, o semitom temperado possui a razão $1.059 .463 .094 / 1.000 .000 .000$, muito distante portanto, tanto dos semitons naturais quanto da própria fundamental (DANIÉLOU, 1995, p. 133).

Daniélou aponta que as características metafísicas da escala maior, a escala padrão ocidental, somada às deficiências de significação proporcionadas pela adoção do temperamento igual, acabam "formando um quadro em que a mentalidade de nossos tempos se encontra completamente em casa" ${ }^{\prime 84}$ (DANIÉLOU, 1995, p. 130).

\subsubsection{A escala dos sons}

Daniélou elabora uma escala que une a escala cíclica de quintas e a escala de proporções. Para isso utiliza intervalos com base nos números primos até cinco, considerando que o número sete estaria além dos domínios do humano. Chega ao número de 53 notas, assim como a escala chinesa. A função desta escala é não só servir como padrão para a medição dos intervalos que, segundo Daniélou, existem de uma ou de outra maneira em todas as músicas tradicionais, mas também servir como matéria-prima para a criação musical. Além das 53 notas acrescenta mais 12 quartos de tom chegando então a 65 notas.

$\mathrm{Na}$ tabela abaixo vemos as diferentes notas com os nomes anglo-saxão e indiano; numeradas; com sua respectiva razão intervalar e sua medida em savarts, em relação à tônica C (Sa). No subcapítulo 2.2. Matemática: a Escala Universal dos Sons e sua Relação com a Série Harmônica da Parte 2, mostraremos quais os cálculos utilizados por Daniélou para sua elaboração.

\footnotetext{
${ }^{84}$ Forming a frame in which the mentality of our times finds itself completely at home.
} 


\begin{tabular}{|c|c|c|c|c|c|c|c|c|c|c|c|c|c|c|c|}
\hline & Nota & Razão & savarts & & Nota & Razão & savarts & & Nota & Razão & savarts & & Nota & Razão & savarts \\
\hline 1 & $\mathrm{C}(\mathrm{Sa})$ & $1 / 1$ & 0 & 15 & $b$ & $6 / 5$ & 79,18 & 29 & $b$ & $36 / 25$ & 158,36 & & $1 / 4$ & $31 / 18$ & 236,09 \\
\hline 2 & + & $81 / 80$ & 5,40 & & $3 / 4$ & $75 / 62$ & 82,67 & & $3 / 4$ & $90 / 62$ & 161,85 & 43 & $\#$ & $125 / 72$ & 239,58 \\
\hline \multirow[t]{2}{*}{3} & ++ & $128 / 125$ & 10,30 & 16 & - & $8000 / 6561$ & 86,12 & 30 & - & $375 / 256$ & 165,79 & 44 & $\mathrm{~L}-$ & $225 / 128$ & 244,99 \\
\hline & $1 / 4$ & $(30 / 31)$ & 14,24 & 17 & - & $100 / 81$ & 91,51 & 31 & - & $40 / 27$ & 170,70 & 45 & $\mathrm{~L}+$ & $16 / 9$ & 249,88 \\
\hline 4 & $\#$ & $25 / 24$ & 17,73 & 18 & $\mathrm{E}(\mathrm{Ga})$ & $5 / 4$ & 96,91 & 32 & $\mathrm{G}(\mathrm{Pa})$ & $3 / 2$ & 176,06 & 46 & $b$ & $9 / 5$ & 255,27 \\
\hline 5 & $\mathrm{~L}-$ & $256 / 243$ & 22,63 & 19 & + & $81 / 64$ & 102,31 & 33 & + & $243 / 160$ & 181,49 & & $3 / 4$ & $29 / 16$ & 258,28 \\
\hline 6 & $\mathrm{~L}+$ & $16 / 15$ & 28,03 & 20 & ++ & $32 / 25$ & 107,21 & 34 & ++ & $192 / 125$ & 186,39 & 47 & - & $4000 / 2187$ & 262,21 \\
\hline \multirow[t]{2}{*}{7} & $b$ & $27 / 25$ & 33,42 & & $1 / 4$ & $31 / 24$ & 111,15 & & $1 / 4$ & $31 / 20$ & 190,33 & 48 & - & $50 / 27$ & 267,62 \\
\hline & $3 / 4$ & $135 / 124$ & 36,89 & 21 & - & $125 / 96$ & 114,64 & 35 & $\#$ & $25 / 16$ & 193,82 & 49 & $\mathrm{~B}(\mathrm{Ni})$ & $15 / 8$ & 273,99 \\
\hline 8 & - & $800 / 729$ & 40,36 & 22 & - & $320 / 243$ & 119,54 & 36 & $\mathrm{~L}$ & $128 / 81$ & 198,71 & 50 & + & $243 / 128$ & 278,40 \\
\hline 9 & - & $10 / 9$ & 45,76 & 23 & $\mathrm{~F}(\mathrm{Ma})$ & $4 / 3$ & 124,94 & 37 & b & $8 / 5$ & 204,12 & 51 & ++ & $48 / 25$ & 283,31 \\
\hline 10 & $\mathrm{D}(\mathrm{Re})$ & $9 / 8$ & 51,14 & 24 & + & $27 / 20$ & 130,36 & & $3 / 4$ & $50 / 31$ & 207,61 & & $1 / 4$ & $60 / 31$ & 286,79 \\
\hline 11 & + & $256 / 225$ & 56,07 & 25 & ++ & $512 / 375$ & 134,70 & 38 & - & $81 / 50$ & 209,52 & 52 & - & $125 / 64$ & 290,73 \\
\hline \multirow[t]{2}{*}{12} & ++ & $125 / 108$ & 61,10 & & $1 / 4$ & $62 / 45$ & 139,18 & 39 & - & $400 / 243$ & 216,45 & 53 & - & $160 / 81$ & 295,63 \\
\hline & $1 / 4$ & $93 / 80$ & 63,39 & 26 & $\#$ & $25 / 18$ & 142,67 & 40 & A (Dha) & $5 / 3$ & 221,85 & 54 & $\mathrm{C}(\mathrm{Sa})$ & 2 & 301,03 \\
\hline 13 & $\#$ & $75 / 64$ & 68,88 & 27 & $\mathrm{~L}-$ & $45 / 32$ & 148,06 & 41 & + & $27 / 16$ & 227,24 & & & & \\
\hline 14 & $\mathrm{~L}$ & $32 / 27$ & 73,79 & 28 & $\mathrm{~L}+$ & $64 / 45$ & 152,97 & 42 & ++ & $128 / 75$ & 232,15 & & & & \\
\hline
\end{tabular}

Tabela 5: Escalas dos sons, 53 notas mais 12 quartos de tom, total 65 notas.

\subsection{Semântica Musical}

Sémantique Musicale foi publicado originalmente em 1967. Em 1978 uma segunda edição foi acrescida de uma Introdução, escrita por Françoise Escal, e de um Anexo de um projeto de construção de um instrumento de teclado. A edição utilizada aqui é uma nova tiragem desta segunda edição publicada em 1993.

Neste livro, Daniélou também baseia o desenvolvimento de seu tema na questão dos intervalos e seu simbolismo numérico. Porém, enquanto no Music and the power of sound ele utilizava os intervalos para tratar de questões étnicas e históricas, aqui ele os toma como base para uma análise do subjetivo, de como se dá a significação musical em nosso aparelho áudiomental. Daniélou pretende com isso investigar a possibilidade da ocorrência de um fenômeno 
musical objetivo ${ }^{85}$, que causasse determinado efeito ou possuísse a mesma significação para todas as pessoas, analisando também o porquê da ocorrência de efeitos diversos e até contraditórios causados nos ouvintes por uma mesma música. Sua referência aqui é o texto Elementary thinking and the classification of behavior (1962) de Henry S. Marck ${ }^{86}$ e os livros Cybernetics (1962) de Wiener ${ }^{87}$ e Vues nouvelles sur le monde des sons (1960) de Fritz Winckel $^{88}$.

\subsubsection{O problema musical}

Partindo do princípio de que não é possível isolar a percepção sonora de sua significação, uma vez que de tal percepção depende nossa própria sobrevivência, Daniélou considera que nosso aparelho mental funciona com dados objetivos, ou seja, com percepções sonoras que possuam significação emotiva ou intelectual, ainda que possamos realizar tal isolamento por meio de treinamento especial.

Contudo, ele considera injustificáveis as duas principais explicações sobre as contradições existentes com relação ao valor expressivo atribuído aos diferentes intervalos em diversos sistemas musicais: tanto a proposta de que tais significações sejam meramente convencionais ou culturais, quanto a ideia de que a estrutura física de diversos grupos étnicos sejam diferentes, gerando portanto diferentes interpretações.

Daniélou entende que é possível “encontrar constantes absolutas na reação áudiomental a certas relações sonoras. Estas reações são ligadas ao mecanismo cerebral pelo qual nós classificamos os sons e lhes atribuímos uma significação" ${ }^{\text {89 }}$ (DANIÉLOU, 1993, p. 14). E que também é possível explicar as divergências de interpretação de intervalos praticamente equivalentes, porém sutilmente diferentes, pois sua interpretação se daria por circuitos cerebrais também diferentes. Esta é sua principal hipótese neste livro.

\footnotetext{
${ }^{85}$ Como nos mostra Sylvia Leite, "No sufismo, [...] objetividade significa a realidade absoluta do Universo, enquanto todas as realidades do mundo formal são tidas como subjetivas, por dizerem respeito a um único entre os inumeráveis pontos de vista" (LEITE, 2009, 28n). Entendemos que devido às características religiosas do pensamento de Daniélou, sua concepção de objetividade é similar a esta.

${ }^{86}$ Trata-se aqui de Henry J. Mark, pediatra e otorrinolaringologista.

${ }^{87}$ Norbert Wiener (1894-1964), matemático estadunidense fundador da Cibernética. Seu livro Cybernetics: Or Control and Communication in the Animal and the Machine foi editado inicialmente em 1948 com uma segunda edição revisada em 1961 e reimpressa em 1962. Utilizamos a reimpressão de 1962.

${ }^{88}$ Fritz Winckel (1907-2000), engenheiro acústico austro-alemão e pioneiro da música eletrônica.

${ }^{89}$ Trouver des constantes absolues dans la réaction audio-mentale à certains rapports sonores. Ces réactions sont liées au mécanisme cérébral par lequel nous classifions les sons e leur attribuons une signification.
} 
Ele cita como exemplo duas expressões que possuem a mesma sonoridade em francês e em inglês, respectivamente mais oui e may we, mas que possuem dois significados diversos.

Transportando para a música, seria similar ao que aconteceria ao se comparar, por exemplo, um intervalo de terça maior do sistema ocidental com o intervalos de terça maior do sistema chinês. Cada um deles teria uma determinada significação, por serem intervalos completamente diferentes, embora próximos, pois seriam interpretadas por regiões distintas de nosso circuito mental (DANIÉLOU, 1993, p. 14-15).

Repetimos aqui a citação que Jorge Antunes utilizou em seu artigo $O$ silêncio, porém agora em nossa própria tradução:

Nosso aparelho mental funciona como uma máquina de calcular que quando os dados de um problema lhe são fornecidos - no caso a significação das relações entre os sons -, continua a funcionar até a descoberta de uma solução aceitável. Nós ignoramos completamente um grande número de elementos sonoros porque eles não estão conectados em um conjunto inteligível. Em contrapartida, nós podemos registrar sons, mesmo muito tênues, emitidos em um contexto sonoro muito mais intenso porque existem ligações lógicas entre eles. É por isso, por exemplo, que somos capazes de acompanhar uma conversa em um lugar muito barulhento ${ }^{90}$. (DANIÉLOU, 1993, p. 15)

\subsubsection{Os dados e sua interpretação}

Segundo Henry J. Marck, em seu texto Elementary thinking and the classification of behavior, publicado em 1962, nosso mecanismo mental funciona de acordo com comparações estatísticas entre os dados que nos chegam e determinados figuras-tipo (padrões) fornecidos pela memória, ou seja, há um feedback, uma realimentação, que permite esta comparação (apud DANIÉLOU, 1993, p. 17) ${ }^{91}$.

Com relação ao som, segundo Fritz Winckel em Vues nouvelles sur le monde des sons, (WINCKEL, 1960) não se percebe todos os seus elementos constitutivos. Mesmo sabendo que os sons são formados por diversos parciais em evoluções diversas durante a duração do

\footnotetext{
${ }^{90}$ Notre appareil mental fonctionne comme une machine à calculer qui, lorsque les données d'un problème lui sont fournies - ici la signification de rapports de sons -, continue à fonctionner jusqu'à la découverte d'une solution acceptable. Nous ignorons complètement un grand nombre d'éléments sonores parce qu'ils ne sont pas connectés dans un ensemble intelligible. Par contre, nous pouvons enregistrer des sons, même très ténus, émis dans un contexte sonore beaucoup plus intense parce qu'il existe entre eux des liens logiques. C'est ainsi, par exemple, que nous sommes capables de suivre une conversation dans un endroit bruyant.

${ }^{91}$ Cf. Marck, 1962.
} 
evento sonoro, o que é responsável pela sua identificação tímbrica, o cérebro percebe este evento como um todo, elaborando e se reportando a uma espécie de padrão simbólico deste som, realizando uma fusão desta complexidade sonora (apud DANIÉLOU, 1993, p. 17-18).

As figuras-tipo, ou padrões, são armazenados durante os processos de aprendizagem, e quando novos dados alimentam nosso cérebro, dispara-se um processo de comparação e feedback entre estes novos dados e os padrões armazenados pela memória, o que torna possível também determinadas previsões sobre eventos futuros (DANIÉLOU, 1993, p. 18).

Em Cybernetics, Norbert Wiener por sua vez afirma que o cérebro, ao contrário de uma máquina de calcular, que sempre pode começar uma determinada operação do zero, funciona com o processamento de informações que o alimentam, em conjunto com os dados armazenados pela memória, e com informações que lhe são adicionadas no momento mesmo da captação de dados e do processamento de informações (WIENER, 1962, p. 19).

Daniélou entende então que a previsão é um elemento constante em nossa percepção, pois nesse sistema de feedback entre os dados que chegam e sua comparação com os elementos armazenados na memória, o ser humano estaria sempre deduzindo sequências prováveis para determinadas frases ou exposição de ideias, que seriam corrigidas a cada informação nova.

Em uma conversa estas operações seriam ainda mais complexas, pois as previsões mudariam de acordo com o interlocutor e de acordo com a resposta dada para as questões colocadas, haveria então um jogo imprevisível de entradas, saídas e trocas de informação.

A música improvisada, seria análoga a uma conversa na linguagem falada. Enquanto uma música escrita e já conhecida anteriormente pelo ouvinte anteciparia respostas que o executante ainda não teria proposto, cuja variação seria bastante sutil de interpretação para interpretação, ou seja, as variações das expectativas no caso de uma música já conhecida darse-iam a partir de um dado já registrado e estático, já na música improvisada, estas previsões e expectativas seriam resultado do efeito das impressões recebidas por um mecanismo já em movimento. De qualquer maneira a criação nasceria de uma mútua cooperação entre ouvinte e intérprete.

Afirma Daniélou:

A linguagem, falada ou musical, e a comunicação podem então ser vistas entre os seres humanos como uma operação de indicação de problemas em um contexto particular de mecanismos cerebrais funcionando segundo certos dados de coordenação. Quanto mais esta coordenação é facilmente estabelecida e maior o seu âmbito, maior a possibilidade de criação. Compreende-se facilmente que quanto maior o vocabulário comum entre o 
orador e seu auditório, mais elevada é a sutileza da criação oratória. ${ }^{92}$ (DANIÉLOU, 1993, p. 21)

O contínuo feedback estatístico entre análise dos dados que chegam em associação com os elementos armazenados na memória pode transformar-se em operações quantitativas de medição, conectando a percepção e a ação mental ou física. Segundo Marck, ocorre uma abstração numérica e de medição que pode descrever as similaridades e diferenças entre os fenômenos observáveis (MARCK, 1962, p. 78). É este sistema abstrato de medida que Daniélou pretende determinar com relação à audição dos sons musicais.

Considerando que os sons físicos muitas vezes apenas circunscrevem, devido às limitações físicas, o que as estruturas harmônicas representam como figuras-tipo na mente, assim como as palavras circunscrevem as ideias que se pretende expressar, Daniélou entende que "uma certa indeterminação ou imprecisão dos sons não implica necessariamente uma imprecisão da ideia musical que se quer expressar" ${ }^{93}$ (DANIÉLOU, 1993, p. 23). Existiria, portanto, uma constante mental à qual as variáveis perceptivas seriam comparadas, e estas constantes seriam a base de toda linguagem musical inteligível.

Determinadas relações sonoras que fossem emitidas de maneira mais precisas possíveis, mais próximas ou idênticas às figuras-tipo mentais, não mudariam o sentido da frase musical, mas suprimiria "a necessidade da entrada em funcionamento de um mecanismo mental que interprete os sons que se aproximam do sentido das figuras-tipos que eles procuram representar" ${ }^{94}$ (DANIÉLOU, 1993, p. 23).

Para definir com precisão o que seria variável - o som físico impreciso - e o que seria constante - as figuras-tipo mentais - na percepção musical, Daniélou afirma que

Muitos elementos entram aqui em jogo: $1^{\circ}$ a memória e a natureza das formas-tipo registradas e classificadas por ela, $2^{\circ}$ a estrutura dos mecanismos cerebrais e nervosos e as formas das figuras que lhes são adaptadas e que são de natureza a provocar reações emocionais ou intelectuais, $3^{\circ}$ as correspondências entre as sucessões de "entradas", os mecanismos mentais e os sinais de prazer correspondentes. ${ }^{95}$ (DANIÉLOU, 1993, p. 23)

\footnotetext{
${ }^{92}$ Le langage, parlé ou musical, et la communication peuvent donc être envisagés chez les êtres humains comme une opération de signalisation de problèmes dans un contexte particulier de mécanismes cérébraux fonctionnant selon certaines donnés de coordination. Plus cette coordination est facilement établie et plus son ambitus est large, plus la création a de possibilités. On comprend aisément que plus l'orateur et son auditoire ont de vocabulaire commun, plus la subtilité de la création oratoire est élevée.

${ }^{93}$ Une certaine indétermination ou imprécision des sons n'implique pas nécessairement une imprécision de l'idée musicale qu'ils cherchent à exprimer.

${ }^{94}$ La nécessité de l'entrée en fonction d'un mécanisme mental qui interprète les sons approximatifs dans le sens de la figure-type qu'ils cherchent à représenter.

${ }^{95}$ Plusieurs éléments entrent ici en jeu : $1^{\circ}$ la mémoire et la nature des formes-type enregistrées et classifiées par elle, $2^{\circ}$ la structure des mécanismes cérébraux et nerveux et la forme des figures qui leur sont adaptées et qui
} 
No caso da música, afirma Daniélou, os elementos que são fontes das sensações de prazer são de natureza eminentemente numérica, pois o que ouvimos são essencialmente relações de frequência, tempo, intensidade e combinações entre essas relações. No entanto nem todas as relações possíveis ocorrem no fenômeno musical, algumas são fundamentais, outras são ambíguas e outras ainda são simplesmente excluídas.

A limitação na seleção de determinadas relações seria justificada pelo funcionamento de nosso aparelho mental. Daniélou afirma:

Parece que nosso mecanismo mental funciona como uma máquina de calcular que combinaria circuitos trabalhando em binário, ternário e quinário. Esta parece ser a única explicação, aplicável em todos os casos conhecidos, da importância de certos intervalos, do valor relativo de outros e da exclusão de alguns, nos diversos sistemas musicais. ${ }^{96}$ (DANIÉLOU, 1993, p. 24)

Daniélou toma como base a música modal, tanto a música grega antiga quanto as músicas indiana ou iraniana contemporâneas. Entre suas justificativas para esta escolha está o fato da música modal possuir uma tônica ou bordão fixo durante toda a execução musical, ao qual todos os intervalos ocorrentes se reportam de modo preciso e constante, e por aparentemente ser o ponto de partida dos principais sistemas musicais. Como durante a execução musical os mesmos intervalos são repetidos sempre na mesma altura e sempre com o mesmo valor expressivo e significação, a audição torna-se progressivamente mais e mais sensível à exatidão destes intervalos (DANIÉLOU, 1993, p. 24-25).

Contudo, quando a exatidão destes intervalos são desprovidas de sentido, como por exemplo quando são baseadas apenas em fórmulas matemáticas presentes em toda a história da música, de Pitágoras a Zarlino, de Ptolomeu a Rameau, passando pelos teóricos chineses e árabes como Yo Ki ou Avicenna, Daniélou considera que estes mesmos intervalos são apenas aproximados dos dados psicofisiológicos da linguagem musical.

Nosso mecanismo cerebral é feito para analisar e comparar as informações úteis, as sensações, as emoções, as ideias, e delas derivar diretivas de ação. Nosso cérebro não é um aparelho de medida para elementos vazios de

sont de nature à provoquer des réactions émotionnelles ou intellectuelles, $3^{\circ}$ les correspondances entre les successions d' "entrées 》, les mécanismes mentaux et les signaux de plaisir correspondants.

${ }^{96}$ Il semble bien que notre mécanisme mental fonctionne comme une machine à calculer qui combinerait des circuits travaillant en binaire, ternaire et quinternaire. Ceci paraît être la seule explication, applicable dans tous les cas connus, de l'importance de certains intervalles, de la valeur relative des autres et de l'exclusion de certains, dans les divers systèmes musicaux. 
conteúdo. Isto é bastante aparente em nosso mecanismo de audição. [...] Nós diferenciamos mal os sons isolados. As pequenas diferenças entre os intervalos executados fora de todo contexto musical, nos parecem insignificantes e mesmo imperceptíveis, enquanto que essas mesmas diferenças em um contexto melódico expressivo mudam completamente o sentido da melodia ou do acorde. ${ }^{97}$ (DANIÉLOU, 1993, p. 26)

\subsubsection{Natureza e limites das percepções sonoras}

Entretanto, para que se possa adentrar nas justificativas e análises das possíveis interpretações das significações musicais, Daniélou descreve nossos limites físicos perceptivos.

Nossa audição é limitada com relação à quantidade de tempo necessária para identificar e analisar eventos sonoros, seja no parâmetro das alturas, durações intensidades ou timbres.

Martin Joos chama de "mancha de tempo de percepção"98 uma zona de incerteza temporal de aproximadamente um vigésimo de segundo, que faz com nossa percepção de um som seja imprecisa no início de sua audição (JOOS, 1948, p. 74-77). Esta mancha desaparece aproximadamente após um décimo de segundo, segundo Fritz Winckel. Portanto, quando há a ocorrência de mais de dez sons por segundo não se pode percebê-los de maneira precisa, além disso um som que dura um décimo de segundo oscilaria numa banda de frequência de $20 \mathrm{~Hz}$, que é a frequência mais grave que pode ser ouvida por um ser humano (apud DANIÉLOU, 1993, p. 31) ${ }^{99}$.

Os sons cujas frequências encontram-se entre 10 e $20 \mathrm{~Hz}$ estariam no limiar entre o ritmo e o som contínuo ${ }^{100}$. Neste intervalo de frequência estaria também o ritmo alfa do cérebro,

\footnotetext{
${ }^{97}$ Notre mécanisme cérébral est fait pour analyser et comparer des informations utiles, des sensations, des émotions, des idées, et en dériver des directives d'action. Notre cerveau n'est pas un appareil de mesure pour des éléments vides de contenu. Ceci est très apparent dans le mécanisme de l'audition. [...] Nous différencions mal des sons isolés. De petites différences entre des intervalles exécutés en dehors de tout contexte musical, nous semblent insignifiantes e même imperceptibles, alors que ces mêmes différences dans un contexte mélodique expressif changent complètement le sens de la mélodie ou de l'accord.

${ }^{98}$ Perception time smear

${ }^{99}$ (Winckel, 1960, p. 39)

${ }^{100}$ Tais considerações, e suas possíveis decorrências musicais, podem ser encontradas também em STOCKHAUSEN, Karlheinz. A Unidade do Tempo Musical (1961) In: MENEZES, Flo (Org.) Música Eletroacústica: história e estéticas. São Paulo: Edusp, 1996. p. 141-9.
} 
que parece ser de fato a base que determina o valor do tempo relativo e por consequência todas as relações do ser vivo com seu ambiente. Ele condiciona todas as percepções. [...] O ritmo alfa desempenha um papel fundamental na linguagem musical porque ele representa o limite onde a pulsação cessa de ser percebida como um elemento rítmico para nos aparecer como uma cor sonora pertencente à escala melódica. ${ }^{101}$ (DANIÉLOU, 1993, p. 33)

$\mathrm{O}$ ritmo alfa estaria aproximadamente entre 10 e $15 \mathrm{~Hz}$. Abaixo de $15 \mathrm{~Hz}$ não se percebe mais o som como altura e abaixo de $10 \mathrm{~Hz}$ o som torna-se pulsação rítmica. Tal limite pode variar levemente de pessoa para pessoa, mas é nessa zona de imprecisão, em que já não se é altura, mas que ainda não é ritmo, que se encontra o ritmo alfa (DANIÉLOU, 1993, p. 3334)

Outro limite perceptivo apontado por Daniélou, diz respeito à relação entre altura e intensidade. Sons muito fortes mudam nossa percepção de sua altura. Por vezes a altura é percebida como mais baixa, no caso dos sons graves, em outras ela é percebida como mais aguda (DANIÉLOU, 1993, p. 34-35).

A criação de um clima musical por meio de um bordão, no caso da música modal, também é possível de ser explicado como um dado que depende dos limites físicos perceptivos. Conforme explica Winckel, existe uma espécie de inércia que impede a interpretação imediata de um som ouvido sem preparação. O bordão seria o responsável por manter o aparelho mental num estado receptivo que permitiria uma interpretação mais rápida e precisa dos sons ouvidos (DANIÉLOU, 1993, p. 36).

Daniélou aponta que a percepção do timbre também depende de diversos fatores. É difícil a identificação de determinado timbre quando a duração do som é muito curta. As formas de ataque e extinção do som também influenciam em sua percepção. Os limites que separam a percepção da altura e do timbre também não são facilmente definidos, sendo o limite de percepção de diferentes alturas aproximadamente $3 \mathrm{~Hz}$ para os sons abaixo de $1000 \mathrm{~Hz}$, segundo Winckel. Isto significa que é possível perceber aproximadamente 85 alturas elementares nas oitavas médias.

\footnotetext{
${ }^{101}$ semble être en fait la base qui détermine la valeur du temps relatif et par conséquent tous les rapports de l'être vivant avec son environnement. - Il conditionne toutes les perceptions. [...] Le rythme alpha joue un rôle fondamental dans le langage musical puisqu'il représente la limite où la pulsation cesse d'être perçue comme un élément rythmique pour nous apparaître comme une couleur sonore appartenant à l'échelle mélodique.
} 


\subsubsection{Bases numéricas das percepções sonoras}

Daniélou explica da seguinte maneira a interpretação numérica de nossa percepção sonora:

Dada a estrutura de nossa orelha e do minúsculo tambor que é o tímpano, é evidente que percebemos os sons não como curvas de frequência, como ondas vibratórias, mas como sequências de pressão e depressão, como sucessão de golpes.

Nosso poder de análise na região melódica do espectro sonoro, é similar àquela da região rítmica. ${ }^{102}$ (DANIÉLOU, 1993, p. 39)

A partir desta ideia, Daniélou entende que, mesmo que a orelha possa captar qualquer som, cabe ao cérebro definir o que deve ou não ser analisado ou reconhecido como um elemento musical. Além disso, considera que o cérebro possui um poder de discriminação limitado, mas que seria similar para diversos órgãos dos sentidos.

Baseando-se no texto Psychometabolism (1963) de Julian Huxley, Daniélou dá como exemplo o fato de que podemos dizer sem refletir quantas maçãs existem numa cesta, desde que este número seja limitado a cinco. Caso exista mais do que esta quantidade, tendemos a subdividir o conjunto. Se forem seis, pensamos em dois grupos de três, se forem sete, subdividiremos em um grupo de três e outro grupo de quatro. Sem tal subdivisão seria impossível apreender de imediato um conjunto de sete frutas. ${ }^{103}$ (DANIÉLOU, 1993, p. 41)

Em termos sonoros, nós podemos estudar este fenômeno em estado puro. Nosso cérebro classifica imediatamente os fatores 2,3 e 5 e certos de seus múltiplos ou produtos mesmo bastante elevados, mas ele cessa de funcionar quando alimentamos seu mecanismo com números primos superiores a 5 . De acordo com experiências que pude fazer sobre a música modal indiana tudo indica que podemos encarar nosso mecanismo cerebral como uma máquina de calcular que funcionaria nos sistemas binário, ternário e quinário, e não

${ }^{102}$ Étante donné la structure de notre oreille et du minuscule tambour qu'est le tympan, il est évident que nous percevons les sons non pas comme des courbes de fréquences, des ondes vibratoires, mais comme des séquences de pression et de dépression, comme des successions de coups. Notre pouvoir d'analyse dans la région mélodique du spectre sonore, est similaire à celui de la région rythmique.

103 "Um dos casos mais conhecidos é a habilidade de contar dos pássaros. O professor Otto Koehler, na Alemanha, descobriu que gralhas tem uma capacidade de contagem não-verbal tão boa quanto a dos seres humanos. Elas podem distinguir conjunto de objetos de acordo com seu número sozinhas, até sete, que é o limite da contagem não-verbal para a maioria dos humanos. Claro que, se empregarmos a contagem verbal 1 - 2 - 3 - 4 - 5 - 6 e assim por diante - podemos distinguir números muito grandes; mas sem isso nós não podemos fazer melhor do que uma gralha" (HUXLEY, 1963, p. 192). 
somente em binário como as calculadoras industriais. ${ }^{104}$ (DANIÉLOU, 1993, p. 41)

Daniélou esclarece também que as reações psicoemotivas ligadas a cada um destes sistemas numéricos são de ordens diferentes, ou seja, cada um destes sistemas interpretam os dados recebidos de forma qualitativamente diversa, não se tratando apenas de grandezas de ordem quantitativa.

O fator 2 Daniélou associa à oitava em nosso sistema de alturas. Daniélou esclarece que o termo oitava faz sentido apenas em uma escala heptatônica, pois seria seu oitavo som, no entanto utiliza este termo para um melhor entendimento.

A oitava ou fator 2, a linguagem binária, Daniélou associa com o espaço. Trata-se de um quadro em que a partir dele tudo se repete. É por meio da oitava que nos damos conta do caráter logarítmico da percepção das alturas. Quando comparamos a diferença de frequência existente entre a oitava Dó e Dó ${ }_{1}$ cujas frequências são aproximadamente $32 \mathrm{~Hz}$ e $64 \mathrm{~Hz}$ respectivamente, e a oitava Dó 3 e Dó 4 cujas frequências são aproximadamente $256 \mathrm{~Hz}$ e $512 \mathrm{~Hz}$ respectivamente, notamos que temos a mesma sensação de repetição de notas, porém no primeiro caso a diferença de frequência é de $32 \mathrm{~Hz}$ e no segundo de $256 \mathrm{~Hz}$.

Daniélou também chama a atenção para o fato de que acima de $500 \mathrm{~Hz}$ tendemos a perceber as oitavas de maneira mais grave do que aquela que seria calculada de maneira numérica. Se observarmos um piano afinado auditivamente veremos que suas oitavas agudas possuem uma diferença de frequência maior do que aquela que seria definida numericamente.

Este mesmo fator 2 é percebido ritmicamente, seja nas subdivisões de tempo, ou pulsação, como nas divisões maiores em que se agrupam compassos para formar frases e seções, o que explicaria as quadraturas e repetições, que delimitariam "espaços" nos quais as ideias musicais seriam apresentadas (DANIÉLOU, 1993, p. 42-44).

O fator 3 é associado com o intervalo de quinta justa. Assim como a oitava é entendida como uma representação espacial, a quinta associa-se com a ideia de movimento, de atividade, de motor. Daniélou também esclarece que o termo quinta se deve à escala heptatônica, em que este intervalo ocupa o quinto grau.

Foi por meio do ciclo repetido deste intervalo que os Gregos e os Chineses elaboraram

\footnotetext{
${ }^{104}$ En termes sonores, nous pouvons étudier ce phénomène à l'état pur. Notre cerveau classe immédiatement les facteurs 2, 3 et 5, e certains de leurs multiples ou produits même assez élevés, mais il cesse de fonctionner lorsqu'on nourrit son mécanisme avec des nombres premiers supérieurs à 5. D'après les expériences que j'ai pu faire sur la musique modale indienne il apparaître que nous pouvons envisager notre mécanisme cérébral comme une machine à calculer qui fonctionnerait en système binaire, ternaire et quinternaire et non pas seulement en binaire comme les calculatrices industrielles.
} 
suas escalas, concentrando todas as notas resultantes reduzidas ao mesmo quadro de oitava. No caso dos chineses a escala se limitou a cinco notas, e no caso do grego foi utilizada uma quinta descendente, que serviu como o quarto grau.

Daniélou esclarece que as quintas ascendentes, representadas pela relação $3 / 2$, e as quintas descendentes - ou quartas ascendentes, quando colocadas numa mesma oitava -, representadas pela relação $2 / 3$ são interpretadas por circuitos mentais diferentes, ainda que complementares e paralelos (DANIÉLOU, 1993, p. 45)

Assim como no caso da oitava, o fator 3 também pode ocorrer na percepção rítmica, quando temos métricas ternárias ou subdivisões ternárias do pulso, e que durante muito tempo no ocidente antigo foi considerado o ritmo perfeito (cf. COTTE, 1991).

Por sua vez, o fator 5 é representado pelos intervalos de terças. Segundo Daniélou, este seria o mais importante fator na música, pois em nosso mecanismo mental ele seria responsável pela expressão de sentimento, sensação e emoção. E no caso de seu paralelo visual, o pentágono, estaria associado ao crescimento, à vida, pois é impossível dividir uma superfície regularmente com pentágonos, ou criar uma superfície somando pentágonos, como é possível ao se combinar triângulos, quadrados ou mesmo hexágonos. Os pentágonos sempre se multiplicam em tamanho ou quantidade.

A terça maior é representada pela relação $5 / 4$, enquanto a terça menor é representada pela relação $6 / 5$. Ao contrário do ciclo de quintas - fator 3 , o fator 5 atinge facilmente seu limite. "O fator 25 (ou seja $5^{2}$ ) fornece os intervalos muito importantes para sua ação psicofisiológica, mas o fator 125 (ou seja $5^{3}$ ) sai dos limites dos intervalos reconhecidos pela audição e classificados mentalmente"105 (DANIÉLOU, 1993, p. 46).

Com relação ao fator 7 , Daniélou considera que ele sai das possibilidades da linguagem musical. Nós não possuiríamos "engrenagem" mental para analisar o fator 7 e atribuir-lhe qualquer papel ou associá-lo a qualquer reação emotiva. Quando um intervalo com este fator é ouvido, tendemos a entendê-lo como uma espécie de desvio de outro intervalo mais próximo, que pertenceria a alguma série do fator 3 ou 5 (DANIÉLOU, 1993, p. 48).

Segundo Daniélou, estas três bases numéricas podem se combinar. Pode-se considerar o sistema decimal como um produto de $5 \times 2$, o que nos daria um sistema espacial-emotivo, ou por exemplo $3 \times 2$ em que teríamos um sistema espacial-motor, ou $5 \times 3$ que seria motor -

\footnotetext{
${ }^{105}$ Le facteur 25 (soit $\left.5^{2}\right)$ donne des intervalles très importants par leur action psycho-physiologique, mais le facteur 125 (soit $\left.5^{3}\right)$ sort déjà des limites des intervalles reconnaissables pour l'oreille, et classifiables mentalement.
} 
emotivo.

Desta forma, ele entende que o fato de adotarmos o sistema decimal não se trata de um acaso ditado pelo fato de possuirmos duas mãos com cinco dedos cada, como comumente se explica. "O fato de que nosso principal órgão tátil tenha cinco dedos é a expressão exterior de uma lei fundamental que rege todo nosso ser e em particular todos nossos centros emotivos que funcionam segundo uma numeração quinária"106 (DANIÉLOU, 1993, p. 49). Nossas mãos seriam portanto, a expressão exterior de uma função cerebral espaço-emotiva.

\subsubsection{Dados psicofisiológicos}

Daniélou considera que se levarmos em conta a hipótese de que nosso sistema de classificação mental baseia-se nos sistemas de cálculo binário, ternário e quinário, certos números adquirem importância particularmente diferenciada. Estes circuitos numéricos, responsáveis pela ativação de diferentes circuitos mentais, desencadeariam determinadas reações psicofisiológicas, de forma que seria possível determinar a relação entre fatores numéricos e mecanismos de sensação, emoção e pensamento.

Embora outros elementos entrem em jogo, como por exemplo as variações dinâmicas, ao utilizar estes três sistemas numéricos é possível estabelecer uma aritmética do mecanismo mental. Daniélou afirma ainda que as relações entre estes três sistemas numéricos estariam presentes na origem de todas as teorias musicais. Contudo, na música modal que possui uma tônica fixa é mais fácil detectar estas relações (DANIÉLOU, 1993, p. 55-56).

Tais relações são mais facilmente detectáveis em músicas que utilizem predominantemente instrumentos que não possuem afinação fixa e ou temperada, que possuam um conteúdo emocional e desde que analisadas durante o contexto de sua execução.

O problema de instrumentos com afinação fixa, e principalmente temperada como no caso do piano, ou de músicas cujo conteúdo seja abstrato, não levando em conta os possíveis efeitos psicofisiológicos, é que estes efeitos, embora presentes, são enfraquecidos, pois o sistema áudio-mental despenderia energia com o feedback necessário para interpretação dos intervalos não "naturais", assimilando-os aos intervalos múltiplos de 2, 3 ou 5 mais próximos

\footnotetext{
${ }^{106}$ Le fait que notre principal organe tactile a cinq doigts est l'expression extérieure d'une loi fondamentale qui régit tout notre être et en particulier tous nos centres émotifs qui fonctionnent selon une numération quinternaire.
} 
(DANIÉLOU, 1993, p. 56).

Daniélou afirma que intervalos que possuem razão numérica similar produzirão efeitos psicofisiológicos similares, o que na teoria musical indiana é chamado de Jāti-s ou "família de intervalos":

Entre estas regiões expressivas aparentadas nós temos por exemplo as segundas menores ${ }^{107}$ (Réb ${ }^{25} / 24$ ou seja, $5^{2} / 3 \times 2^{3}$ e Ré $+{ }^{16} / 15$ ou seja $2^{4} / 3 \times 5$ ) de um lado, e de outro as sextas menores (Láb- ${ }^{25} / 16$ ou seja, $5^{2} / 2^{4}$ e Láb $8 / 5$ ou seja $2^{3} / 5$ ), ou as terças menores ( $\mathrm{Mi}, 32 / 27$ ou seja, $2^{5} / 3^{3}$ e Mib $+6 / 5$ ou seja $2 \times$ $3 / 5$ ) de um lado, e as sétimas menores $\left(\mathrm{Si}, 16 \%\right.$ ou seja, $2^{4} / 3^{2}$ e $\mathrm{Si}$, $+9 / 5$ ou seja $\left.3^{2} / 5\right)$, ou ainda as terças maiores ( $\mathrm{Mi} 5 / 4$ ou seja, $5 / 2^{2}$ e $\mathrm{Mi}+81 / 64$ ou seja $3^{4} / 2^{6}$ ) e as sétimas maiores ( $\mathrm{Si}^{15} / 8$ ou seja, $3 \times 5 / 2^{3}$ e $\mathrm{Si}+243 / 128$ ou seja $3^{5} / 2^{7}$ ). ${ }^{108}$ (DANIÉLOU, 1993, p. 58)

A música modal seria a única em que o conteúdo semântico aparece estritamente ligado à natureza dos intervalos. $\mathrm{E}$ as características psicofisiológicas que se pode atribuir às três séries numéricas, segundo Daniélou, seriam as seguintes:

A oitava, ou fator 2, não tem em si um caráter expressivo, representa a dimensão do tempo ou do espaço. Um ritmo binário seria uma pulsação sem efeito afetivo.

As quintas, ou fator 3, representa o movimento, a atividade. Quando ascendente, ou seja, quando o número 3 aparece no numerador, como na quinta $(3 / 2)$ e na segunda maior $(9 / 8)$, possui um caráter ativo, masculino e enérgico; quando o número 3 aparece no denominador, ou seja, quintas descendentes ou quartas ascendentes, como na quarta $(4 / 3)$ e na sétima menor $(16 \%)$, o intervalo possui um caráter passivo, feminino, receptivo ${ }^{109}$.

As terças, ou fator 5, seria responsável pela sentimento e emoção. Tanto do ponto de vista intervalar como do ponto de vista rítmico, o fator 5 desempenha esta função. Ritmos quinários possuem um caráter hipnótico, enquanto os intervalos de terça desencadeiam emoções e sentimentos, que podem ser identificados como melancólicos, sensuais, apaixonados, emotivos, doces ou mesmo cruéis (DANIÉLOU, 1993, p. 63).

Estes sistemas numéricos diferenciam-se em quantitativos, quando aparecem no numerador e qualitativo, quando aparecem no denominador.

\footnotetext{
${ }^{107}$ Considera-se aqui a nota Dó como tônica e $1 / 1$ ou 1 .

${ }^{108}$ Parmi ces régions expressives apparentées nous avons par exemple les secondes mineures (Ré $b^{25} / 24$ soit $5^{2} / 3$ $\times 2^{3}$ et Réb+ $16 / 15$ soit $\left.2^{4} / 3 \times 5\right)$ d'un côté, e de l'autre les sixtes mineures $\left(\right.$ Láb $-{ }^{25} / 16$ soit $5^{2} / 2^{4}$ et Láb ${ }^{8} / 5$ soit $\left.2^{3} / 5\right)$, ou bien les tierces mineures (Mi, ${ }^{32} / 27$ soit $2^{5} / 3^{3}$ et Mib $+6 / 5$ soit $2 \times 3 / 5$ ) d'un côté, et les septièmes mineures $\left(\mathrm{Si}_{1}{ }^{16} / 9\right.$ soit $2^{4} / 3^{2}$ et $\mathrm{Si} /{ }+9 / 5$ soit $\left.3^{2} / 5\right)$, ou bien encore les tierces majeures $\left(\mathrm{Mi} / 4\right.$ soit $5 / 2^{2}$ et Mi+ ${ }^{81} / 64$ soit $\left.3^{4} / 2^{6}\right)$ et les septièmes majeures $\left(\mathrm{Si} \mathrm{i}^{15} / 8\right.$ soit $3 \times 5 / 2^{3}$ et $\mathrm{Si}+{ }^{243} / 128$ soit $\left.3^{5} / 2^{7}\right)$.

${ }^{109}$ Os caracteres masculino e feminino atribuídos aqui aos intervalos não representam juízos de valor, hierarquia ou importância, tratam-se de características atribuídas tradicionalmente aos respectivos gêneros, assim como encontramos na divisão chinesa entre yin (feminino) e yang (masculino).
} 
Existem limites precisos no desenvolvimento destes três sistemas numéricos baseados nos números primos 2, 3 e 5. Eles dependem de dois fatores: o número de múltiplos aceitáveis e a similaridade dos sons produzidos por séries diferentes.

a) quanto aos múltiplos:

O fator espacial 2 não possui limite, podendo ser multiplicado indefinidamente, correspondendo à figura do quadrado;

O fator motor ou ativo 3 , limita-se a $3^{6}$ (729, ou seja, o trítono) e corresponde às figuras triangulares;

O fator emotivo 5 é mais limitado. Como $5^{2}$ (25) é empregado quantitativamente, ou seja, no numerador, criando sentimentos melancólicos, enquanto que seu emprego qualitativo, no denominador, é pouco utilizado pois dá impressão de crueldade e dureza, enquanto que o elemento $5^{3}$ (125) não possui uso conhecido nas linguagens musicais (DANIÉLOU, 1993, p. 66)

b) Quanto à similaridade dos ciclos:

Um exemplo típico que ocorre na maior parte dos sistemas musicais é similaridade entre diversas quartas aumentadas, que podem ser obtidas tanto por ciclos de quintas ascendentes a partir de Dó (Fá\# $+{ }^{729} / 512$ ), ou quintas descendentes - quartas ascendentes (Fá\# 1024/729); e também por meio de múltiplos de 5, como por exemplo 2 quintas acima de uma terça maior ascendente a partir de Dó (Fá\# ${ }^{45} / 32$ ), ou 2 quintas abaixo de uma terça maior descendente a partir de Dó $\left(\right.$ Fá\# $\left.+{ }^{64} / 45\right) 110$.

As quartas aumentadas que pertencem ao mesmo ciclo, possuem entre si uma diferença de altura possível de ser percebida auditivamente. No ciclo de quintas (Fá\# $+{ }^{729} / 512$ ) e (Fá\# $1024 / 729)$, a diferença de altura é de uma coma pitagórica ( $\cong 23,4$ cents); enquanto que no ciclo que inclui uma terça maior a diferença é de uma coma sintônica ou diesis $(\cong 19,5$ cents). Porém ao tomarmos uma quarta aumentada de cada ciclo e compará-las, a diferença entre elas é de $\cong 2$ cents. Esta diferença de altura não se percebe auditivamente.

A ordem crescente destes intervalos é a seguinte: $1024 / 729-2$ cents $-45 / 32-19,5$ cents $64 / 45-2$ cents $-{ }^{729} / 512$.

Segundo Daniélou,

Por consequência da indeterminação resultante de sua própria natureza, estes sons criam uma tensão, uma vacilação do mecanismo mental de uma possibilidade à outra, que faz da quarta aumentada um intervalo tenso, pouco

\footnotetext{
${ }^{110}$ Nos ciclos descendentes a nota correta seria Solb, porém Daniélou utiliza o enarmônico Fá\# sem nenhuma explicação ou justificativa
} 
agradável e de sentido indeterminado. ${ }^{111}$ (DANIÉLOU, 1993, p. 67)

Outros intervalos também apresentam tais ambiguidades e muitas vezes as diferenças entre eles são imperceptíveis auditivamente mas, segundo Daniélou, são analisadas de maneira diferenciada por nosso aparelho áudio-mental.

Combinando-se os ciclos de terça e de quinta chega-se a divisão da oitava em 53 notas que são agrupadas de formas variadas para formar as diferentes escalas dos diferentes sistemas musicais [ver Figura 1 abaixo].

Com relação ao sistema temperado, Daniélou entende que se trata de uma questão que depende mais de um costume que se arraigou e que aos poucos tomou conta da linguagem. À alegação de que as diferenças entre os intervalos seria imperceptível e que a utilização de intervalos naturais seria irrelevante, Daniélou propõe que aquele que pensa não tem consciência de sua própria linguagem até o momento em que precisa exprimir uma ideia que só encontra possibilidade de existência numa outra linguagem, como por exemplo, nas ciências puras, "no caso da impossibilidade de explicar certos dados da física nuclear na linguagem euclidiana" (DANIÉLOU, 1993, p. 71).112

Como justificativa para sua defesa dos intervalos não temperados, dá como exemplo o canto e os instrumentos cuja afinação não é fixa, em que

apenas a escrita parece temperada; a execução tende a seguir instintivamente as relações que são perceptíveis ao nosso aparelho áudio-mental e quando o violinista ou o cantor sentem verdadeiramente a melodia, está emotivamente envolvido na música, ele toca ou canta exatamente os intervalos dos ciclos 2 , 3 e 5, os mesmos que os hindus ou os árabes, mas não sabe que o faz, porque as teorias que ele conhece não lhe dão nenhum elemento preciso de análise. ${ }^{113}$ (DANIÉLOU, 1993, p. 72 destaque do autor)

\footnotetext{
${ }^{111}$ Par suite de l'indétermination résultant de leur nature même, ces sons créent une tension, une vacillation du mécanisme mental d'une possibilité à l'autre, qui fait de la quarte augmentée un intervalle tendu, peu plaisant et de sens indéterminé.

${ }^{112}$ Dans le cas de l'impossibilité d'expliquer certaines donnés de la physique nucléaire dans le langage euclidien.

${ }^{113}$ Seule l'écriture apparait tempérée; l'exécution tend a suivre instinctivement les relations qui sont perceptibles à notre appareil audio-mental et lorsque le violoniste ou le chanteur sent vraiment la mélodie, est émotivement impliqué dans la musique, il joue très exactement des intervalles des cycles 2-3-5, les mêmes que ceux des Hindous ou des Arabes, mais il ne sait pas qu'il le fait, puisque les théories qu'il connaît ne lui donnent aucun élément précis d'analyse.
} 


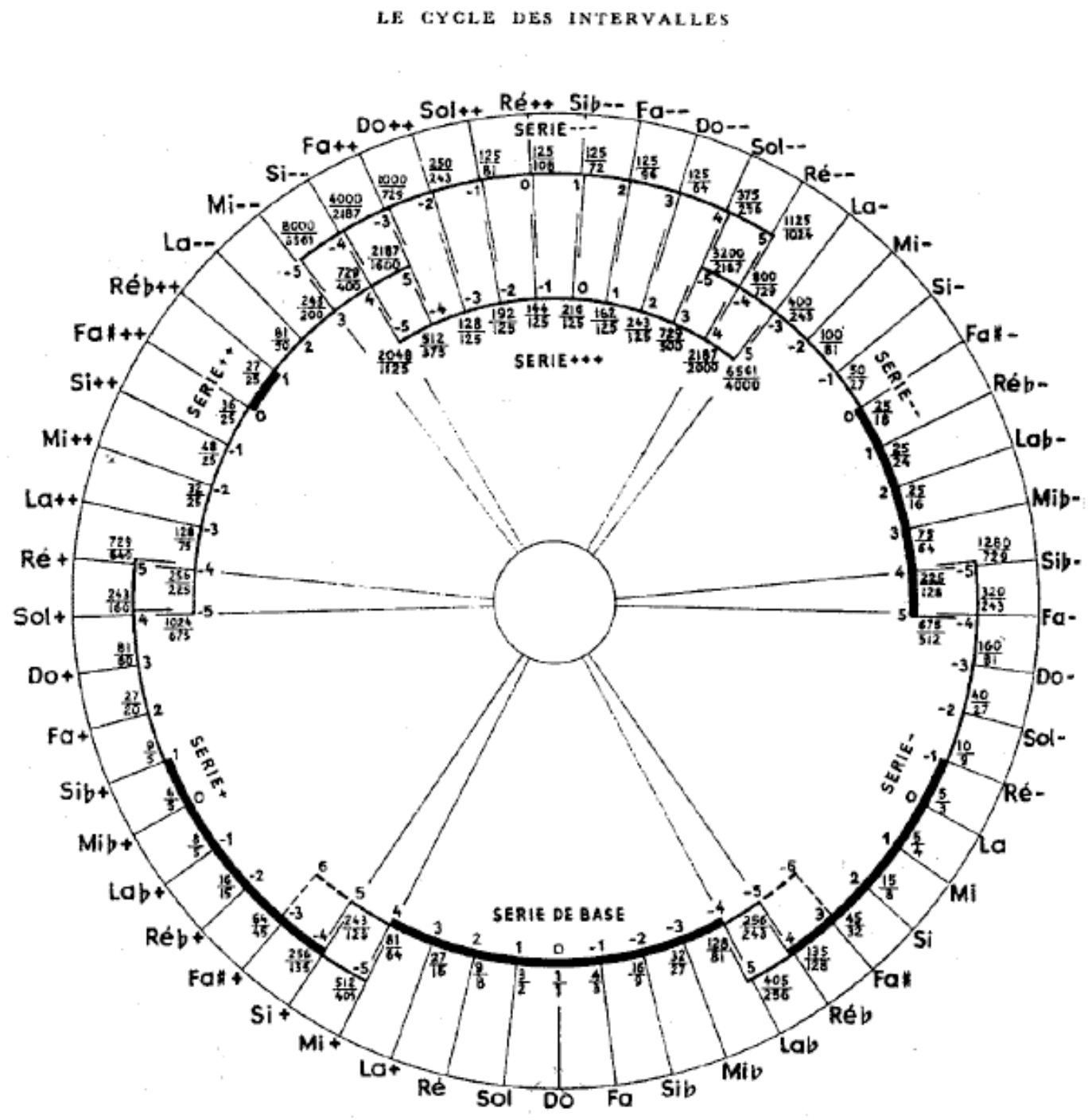

Figura 1: Subdivisão da oitava em 53 sons a partir dos ciclos de terça e de quinta. (DANIÉLOU, 1993, p. 70)

Seria necessário uma reeducação dos músicos a partir destes intervalos, para que fosse possível recuperá-los como figuras-tipo às quais nosso aparelho mental poderia, por meio do mecanismo de feedback, interpretá-los com maior precisão e consciência (DANIÉLOU, 1993, p. 73)

\subsubsection{O vocabulário musical}

As propriedades presentes na escala de 53 sons construída a partir dos números primos 2, 3 e 5, parecem fazer parte de todas as estruturas do mundo natural, pois são ligadas às 
propriedades numéricas e aritméticas elementares. A associação destes números primos com dados emotivos podem nos permitir encontrar relações similares em outras instâncias:

Os limites da materialidade das coisas são determinados por aqueles de nossa possibilidade de percepção. Os mecanismos do pensamento não podem diferir em seu princípio dos mecanismos da formação da matéria, os dados matéria-percepção-pensamento são interdependentes e não podem existir um sem o outro. Eles são de fato indissociáveis e coordenados e representam os diversos aspectos de uma mesma força criativa. ${ }^{114}$ (DANIÉLOU, 1993, p. 76)

Segundo Daniélou, é possível explicar a continuidade existente entre matéria, vida e pensamento, por meio das bases numéricas que são comuns a esses três elementos, possibilitando vislumbrar como a matéria e a vida podem ser encaradas como resultantes do pensamento (DANIÉLOU, 1993, p. 77).

Daniélou explica que, segundo os gramáticos e semanticistas sânscritos, a formulação do pensamento possui quatro fases:

1. “Além" do pensamento (para). Como um espaço vazio onde vagam elementos de pensamentos indeterminados;

2. "Visão" (pashyanti). Visualização de ideia para as quais se procuram palavras apropriadas;

3. "Intermediário" (madhyama). Encontram-se as palavras e formula-se a frase mentalmente;

4. "Manifestação" (vaikhari). Exteriorização da frase em sons perceptíveis. (DANIÉLOU, 1993, p. 77)

No caso da música são os princípios numéricos latentes que vão formar as palavras necessárias ao vocabulário sonoro, de forma que o conteúdo, a ideia, é o princípio organizador do pensamento que busca a forma e os sons para se exprimir (DANIÉLOU, 1993, p. 77).

Alain Daniélou considera, a partir de seus estudos do Sânscrito, que a linguagem total compreenderia a linguagem articulada, a linguagem musical e o gesto, que não seriam completamente independentes. Na linguagem falada, cada sílaba possuiria também um

\footnotetext{
${ }^{114}$ Les limites de la matérialité des choses sont déterminées par celles de nos possibilités de perception. Les mécanismes de la pensée ne peuvent pas différer dans leur principe des mécanismes de la formation de la matière, les données matière-perception-pensée sont interdépendants et ne peuvent exister l'une sans autre. Elles sont en fait indissociables et coordonnées et représentent les divers aspects d'une même force créatrice.
} 
conteúdo semântico, que quando varia conforme sua altura relativa, seria um vestígio de quando língua e música não seriam separadas (DANIÉLOU, 1993, p. 79).

Daniélou considera como o vocabulário musical básico, presente em todos os sistemas musicais, a escala de 53 notas formadas a partir da combinação dos ciclos de terça e quinta. Acrescenta também os ornamentos, que possuem a função de destacar, conduzir ou remeter a nota a um sentido determinado; e também os vibratos, que ao possibilitar uma variação entre intervalos com significados diversos, serviria para gerar uma espécie de ambiguidade, característica da poesia e da arte, mas que na música modal seriam proibidos de serem executados na tônica, na quinta e na quarta, pois seus sons vizinhos não seriam utilizados (DANIÉLOU, 1993, p. 87-89).

\subsubsection{Aplicações}

Daniélou sugere neste capítulo de seu livro algumas aplicações possíveis para a hipótese dos intervalos naturais serem baseados em sistemas numéricos de 2,3 e 5 .

Assim como os Gregos antigos e os Hindus, ele entende que a utilização da música modal, afinada em intervalos naturais e não temperados, serve para a educação moral dos jovens, e cita que experiências da belga L. Gelber ${ }^{115}$ que demonstraram que a música modal seria a mais natural para as crianças.

Ele acrescenta a relação entre música e magia, presente não só na astrologia antiga como também na geometria sagrada utilizada para a construção de catedrais e templos antigos, que seriam baseadas em relações similares àquelas representadas pelos números 2,3 e 5, tais como triângulos, quadrados e pentágonos. Ele considera que tais associações não foram casos arbitrários, e sim um início de ciência num esforço de interpretar a natureza do real, expressa em linguagem matemática.

Tais relações são encontradas também nas músicas de rituais extáticos tais como aqueles dos dervixes iranianos, nas danças mágicas africanas ou ainda de certas populações da Índia ou Indonésia.

Sugere também uma terapêutica musical, em que se poderia submeter pessoas doentes a "banhos de relações sonoras bem definidas, onde os elementos de construção

\footnotetext{
${ }^{115}$ Trata-se de Lucy Gelber, musicóloga e autora entre outros títulos de: L'aptitude tonale de l'enfant, Le chant enfantin: étude psycho-génétique, a partir da década de 1970 baseia-se no sistema Waldorf.
} 
artística são secundários, ainda que possam desempenhar um papel para fixar a atenção"116, estas relações sonoras definidas basear-se-iam nos números primos responsáveis pelos ciclos de terça e quinta.

Daniélou sugere a possibilidade de criação de uma nova música. Ele compara as possibilidades abertas pelo aumento do número de notas numa escala que vai além dos doze sons temperados, com as possibilidades expressivas que possui alguém com um vocabulário maior, pois "quanto mais nosso vocabulário é preciso e extenso, mais nós podemos chegar a exprimir as formas e nuances do pensamento"117 (DANIÉLOU, 1993, p. 94).

E termina afirmando que "a utilização de um vocabulário musical baseado sobre dados psicofisiológicos precisos e sobre um melhor conhecimento do conteúdo semântico dos sons é a chave da arte musical do futuro" 118 (DANIÉLOU, 1993, p. 95).

\subsection{Música e Metafísica em Alain Daniélou}

Para mim, a busca por valores espirituais está intimamente ligada com a vida cotidiana, o senso de humor, e o prazer de estar vivo. Meu corpo e alma nunca estiveram distantes. ${ }^{119}$ (DANIÉLOU, 1987, p. 249)

No penúltimo capítulo de The way to the Labyrinth, intitulado Uma visão hindu do mundo ocidental ${ }^{120}$, Daniélou descreve como se desenvolveu seu modo de pensar a partir de sua estada de mais de vinte anos na Índia, vindo a se considerar menos um francês do que um hindu.

Daniélou relata que antes de se fixar em Benares na Índia, quando vivia na Europa, voluntariamente se afastou das discussões que normalmente ocorriam em seu círculo familiar. Considerando seus familiares mais próximos, como sua mãe, seu pai e seu irmão mais velho o futuro cardeal Jean Daniélou, os assuntos tratados em família frequentemente eram sobre questões culturais: religião, literatura, filosofia e política. Refugiou-se então no estudo da

\footnotetext{
${ }^{116}$ Des bains de relations sonores très définies où les éléments de construction artistique sont secondaires, bien qu'ils puissent aussi jouer un rôle pour fixer l'attention.

${ }^{117}$ Plus notre vocabulaire est précis et étendu, plus nous pouvons arriver a exprimer de formes et de nuances de pensée.

${ }^{118}$ L'utilisation d'un vocabulaire musical basé sur des donnés psycho-physiologiques précises et sur une meilleure connaissance du contenu sémantique des sons est la clé de l'art musical de l'avenir.

${ }^{119}$ For me, the search for spiritual values is closely linked with everyday life, a sense of humor, and the pleasure of being alive. My body and soul have never been far apart.

${ }^{120}$ A Hindu's View of the Western World.
} 
matemática e física, que por aparentemente não serem parte da cultura, não mereciam atenção suficiente, o que o mantinha em relativa paz (DANIÉLOU, 1987, p. 307).

Quando então retorna ao Ocidente, nota que seu raciocínio não havia sido desenvolvido a partir da filosofia ocidental, da qual ele nada conhecia, e sim a partir do que aprendera estudando na Índia, dentro de seus sofisticados círculos culturais tradicionais. Seu pensamento se baseava na

teoria cosmológica hindu, segundo a qual teologia, metafísica, ética e ciências humanas e sociais são vistas como várias aplicações de princípios comuns de natureza universal, e não como entidades separadas. Estes princípios podem ser representados como espécies de protótipos, fórmulas matemáticas ou geométricas cujas propriedades podem ser observadas em todos os aspectos da criação, da composição dos átomos e galáxias aos animais e sociedades humanas, mas também nas estruturas das linguagens musical e falada e, finalmente, nos mecanismos da mente. ${ }^{121}$ (DANIÉLOU, 1987, p. 307)

Esta forma de pensamento guia todas as suas reflexões a respeito da música - o assunto desta tese - e da filosofia, religião e história, assuntos que também tratou em outras obras. A teoria cosmológica hindu é, em seguida, detalhada por Daniélou com relação ao processo a ser percorrido para chegar a determinadas conclusões:

Daí em diante, todas as formas de pensamento organizado, o estudo de qualquer assunto era filtrado mais ou menos conscientemente através da minha mente de acordo com seis métodos cujas conclusões, embora frequentemente contraditórias, torna possível ver os problemas de uma maneira bem equilibrada. Estes métodos, que os hindus chamam "pontos de vista" (darshana) incluem cosmologia, mais especificamente $\mathrm{o}$ "mensurável" (sâmkhya), que coloca qualquer problema no contexto de estruturas universais ou do macrocosmo; yoga, que os considera em relação ao universo interior do homem ou do microcosmo; "ritos" (mîmânsa), que permitem a experiência da relação entre o humano e o sobrenatural; e metafísica (vedanta), que se relaciona com o invisível, o mundo suprassensível. O vaisheshika, por outro lado, é a abordagem científica ou experimental, e tem a ver com o mundo como é percebido através de nossos sentidos, enquanto a lógica (nyaya) permite à mente estabelecer conexões. A esses vários métodos pode-se acrescentar o estudo da natureza da linguagem (vyâkarana), considerada um instrumento imperfeito para a formulação e comunicação de tudo que experimentamos através dos sentidos, que nos permite definir os contornos de nosso pensamento mas cujas limitações

${ }^{121}$ Hindu cosmological theory according to which theology, metaphysics, ethics, and human and social sciences are seen as various applications of common principles of a universal nature, rather than as separate entities. These principles can be represented as kinds of prototypes, geometrical or mathematical formulae whose properties can be traced is all aspects of creation, from the composition of atoms and galaxies to animal and human societies, but also in the structure of musical and spoken languages and, finally, in the mechanisms of mind. 
devem ser reconhecidas para que não se confunda palavras com ideias. ${ }^{122}$ (DANIÉLOU, 1987, p. 307-308 destaques o autor)

Fica claro nesta descrição, principalmente na última frase quando se refere ao estudo da natureza da linguagem, o caráter metafísico do pensamento de Daniélou, pois se não se deve confundir "palavras com ideias" é porque tais termos são considerados distintamente. Logo, se a linguagem é "um instrumento imperfeito para a formulação e a comunicação", uma ideia não poderia ser expressa em sua plenitude através da linguagem ou, poderíamos acrescentar, pelo menos por meio de uma só linguagem, como a linguagem falada ou escrita.

Este tipo de raciocínio é que torna possível a Daniélou escrever Sémantique Musicale e elaborar sua teoria de que certas razões numéricas, percebidas por meio de relações intervalares na música seriam responsáveis por alterações nos estados emocionais da mente. Ou seja, a linguagem musical também poderia ser responsável pela formulação ou comunicação, ainda que também de forma imperfeita.

Apesar desta observação a respeito da linguagem, chama a atenção o fato de Daniélou afirmar que tais métodos de pensamento frequentemente caem em contradição. Entendemos com isso que o caráter metafísico da abordagem de Daniélou, não se baseia na busca de uma verdade permanente, ou numa realidade última. Veremos adiante, no capítulo 3. Como?, as observações do filósofo Giovanni Piana, que considera que a forma como Daniélou relaciona intervalos e razões numéricas, enfatizando o aspecto sensível da percepção intervalar, coloca as considerações metafísicas em segundo plano.

Com relação a este sistema de pensamento que se utiliza dos seis métodos, Daniélou afirma:

A doutrina do darshana é uma base sólida para um pensamento bem equilibrado. $\mathrm{O}$ que pode ser verdade num nível não é necessariamente verdadeiro em outro. Qualquer generalização superficial e precipitada não apenas leva a absurdos mas é também moralmente, socialmente e intelectualmente perigoso. Todos os sistemas são definidos e limitados por

${ }^{122}$ From then on, all forms of organized thinking, the study of any subject filtered more or less consciously through my mind according to six methods whose conclusions, though often contradictory, make it possible to view problems in a well-balanced manner. These methods, which Hindus call "points of view" (darshana) include cosmology, more specifically the "measurable" (sâmkhya), which places any problem within the context of universal structures or macrocosm; yoga, which considers it in relation to man's inner universe or microcosm; "rites" (mîmânsa), which allow one to experience the relationship between the human and the supernatural; and metaphysics (vedanta), which relate to the invisible, suprasensible world. The vaisheshika, on the other hand, is the experimental or scientific approach, and has to do with the world as it is perceived through our senses, while logic (nyaya) allows the mind to establish connexions. To these various methods one may also add the study of the nature of language (vyâkarana), considered as imperfect instrument of formulation and communication of all we experienced through the senses, which allows us to define the contours of our thought but whose limitations must be recognized so that we do not confuse word with ideas. 
seus dados, e tornam-se falsos quando tentam ir além de seus postulados. Como resultado, muitas verdades relativas podem coexistir sem negar uma à outra. $^{123}$ (DANIÉLOU, 1987, p. 308)

É interessante notar a ideia de que várias verdades podem coexistir sem negar uma à outra. Vemos com isso que a ideia de verdade para Daniélou não é algo que deve funcionar como algo único e absoluto. Tal posição permite flexibilidade ao pensamento e consciência de que determinadas afirmações devem ser entendidas em seu respectivo nível.

O importante em qualquer tipo de pesquisa, é determinar de início as limitações dos dados fornecidos. É por isso que a ciência, para os hindus, é necessariamente ateísta, porque o estudo do mundo material não conduz à noção de Deus. Yoga, por outro lado, é teísta porque conduz à experiência mística, enquanto na cosmologia as "causas primeiras" do universo devem ser impessoais. Uma abordagem realista de qualquer problema deve necessariamente levar em conta estes contrastes; um doutor que permite que suas crenças religiosas interfiram com o exercício de sua profissão trai não apenas a ciência, mas também a própria religião. ${ }^{124}$ (DANIÉLOU, 1987, p. 309 destaques do autor)

Tal pensamento se estende para a convivência social. O respeito pelas diferenças, segundo Daniélou, seria um dos aspectos principais da sociedade indiana, Segundo ele "o primeiro dever do homem é entender sua própria natureza e os elementos básicos de seu ser, que ele deve realizar com o máximo de sua habilidade. Seu segundo dever é o respeito à realidade de outras pessoas" ${ }^{\prime 25}$ (DANIÉLOU, 1987, p. 324).

Entretanto, este respeito à realidade de outras pessoas ou povos, não o impede de ser um crítico do mundo ocidental, principalmente no que diz respeito à religião monoteísta, representada no ocidente principalmente pelo cristianismo, considerando que foram rejeitadas todas as tentativas de unir ciência e religião, cosmologia e teologia, com a igreja colocando toda sua atenção na moral e comportamento social, baseando-se em dogmas e crenças. (DANIÉLOU, 1987, p. 326).

\footnotetext{
${ }^{123}$ The darshana doctrine is a solid basis for well-balanced thinking. What may be true on one level is not necessarily true on another. Any hasty a superficial generalization not only leads to absurdities but is morally, socially, and intellectually dangerous. All systems are defined and limited by their data, and become false when they try to go beyond their postulates. As a result, many different relative truths can coexist without negating one another.

${ }^{124}$ The important thing in any kind of research is to determine at the outset the limitations of its given data. This is why science, for Hindus, is necessarily atheistic, for the study of the material world does not lead to the notion of God. Yoga, on the other hand, is theistic for it leads to mystical experience, while in cosmology the "first causes" of the universe must be impersonal. A realistic approach towards any problem must necessarily take these contrasts into account; a doctor who allows his religious beliefs to interfere with the exercise of his profession not only betrays science but religion as well.

${ }^{125}$ The first duty of man is to understand his own nature and the basic elements of his being, which he must fulfill to the best of his ability. His second duty is to respect the reality of other people.
} 
Apesar do caráter metafísico de seu raciocínio e de ter sido iniciado na religião hindu shivaísta, sua crítica aos dogmas e às crenças cegas nestes dogmas é severa:

Eu aprendi há muito tempo que acreditar era o oposto de conhecer. Pessoas não precisam acreditar quando elas conhecem verdadeiramente; elas só acreditam em coisas que elas não conhecem. Crença é sempre uma conselheira muito pobre. ${ }^{126}$ (DANIÉLOU, 1987, p. 325)

Nota-se também em outras passagens, que para ele não basta um conhecimento que seja apenas teórico, é necessário também algum tipo de experiência que proporcione um conhecimento mais completo. Como ele mesmo afirma, sempre sentiu uma espécie de parentesco com os artesãos, pessoas sábias e felizes sempre em contato com a forma e substância do mundo (DANIÉLOU, 1987, p. 331-332).

A busca pelo conhecimento o levou também a presenciar rituais de caráter místicos. No Irã, Daniélou conhece Ernest Perron que lhe apresenta o verdadeiro Irã e seus músicos. Certa vez Perron leva Daniélou a uma cerimônia sufi que assim a relata:

Há trinta milhas de Teerã, em Galand Bagh, o lar de Nizam Sultam Khajenouri, ex-embaixador do Irã em Roma, eu testemunhei as cerimônias extáticas dos sufis. Como muitos iranianos que parecem muito modernos, Nizam era um sufi e profundamente envolvido na tradição mística e poética a que todos os grandes poetas persas pertenceram.

A cerimônia teve lugar em um edifício isolado no jardim. Ernest e eu fomos servidos com chá em uma pequena sala decorada com tapetes e almofadas. Então passamos por uma porta estreita para um salão adjacente repleto de homens sentados no chão. Estava muito escuro. Nós nos sentamos discretamente em um canto, contra uma parede. $O$ silêncio era impressionante, avassalador.

Pouco a pouco, quase imperceptivelmente, um grave murmúrio de orações pareceu emergir desta multidão imóvel de corpos. Então alguém começou a entoar um canto grave, que os outros, ainda murmurando, seguiram em uníssono. O canto tornou-se gradualmente mais e mais forte, cada vez mais rítmico, até se tornar quase ensurdecedor. Um homem se levantou e começou a dançar, fazendo um som contínuo parecido com o de um animal e movimentos de cabeça que os gregos costumavam comparar com os dos touros. Então outros se juntaram a ele. A dança tornou-se cada vez mais frenética, os cantos gradualmente transformaram-se em gritos. O clamor era fantástico, irresistível. Tambores começaram a tocar, dando um andamento à dança. Eu me sentia completamente atordoado, quase hipnotizado. Tempo e espaço pareciam não mais existir. O movimento e os ruídos formaram uma espécie de cone que subia para o céu e parecia se comunicar com um mundo desconhecido. Os dançarinos agiam como se estivessem intoxicados. Eles entraram em transe, gritando e clamando palavras estranhas e incompreensíveis. O som contínuo acelerou e tornou-se cada vez mais

${ }^{126}$ I learned long ago that believing was the opposite of knowing. People do not need to believe when they truly know; they only believe in things that they do not know. Belief is always a very poor counselor. 
espasmódico, misturado com invocações a Allah.

Este frenesi durou mais de uma hora. Então os exaustos participantes começaram a cair no chão, um após outro, numa espécie de ataque cataléptico. O clamor lentamente diminuiu, então subitamente cessou por completo. O salão parecia um campo de batalha coberto com amontoados imóveis de corpos prostrados. Um silêncio abençoado, como uma misteriosa presença, desceu sobre o salão, envolvendo estas vítimas da fé. Ernest e eu saímos silenciosamente, ainda completamente atordoados, ainda sob o encantamento de nossa estranha experiência, o ato mágico de comunicação com o desconhecido que havíamos testemunhado: sentimos-nos transformados, como homens diferentes. Permanecemos por um longo tempo na saleta silenciosa e serena sem dizer uma palavra um ao outro, então caminhamos através de um adorável jardim de rosas de volta à casa principal.

Eu nunca ousei gravar as cerimônias de zeckr. A natureza religiosa deste tipo de experiência é para mim muito intensa para sequer considerar a introdução de algo tão profano como a curiosidade. ${ }^{127}$ Dois de meus assistentes, que eram menos envolvidos pessoalmente, o fizeram: um na Síria, o outro na Iugoslávia, entre os muçulmanos de origem albanesa. Foi possível produzir duas soberbas gravações destas cerimônias. Jochen Wenzel, um jovem e habilidoso técnico que acompanhou os pesquisadores, foi fortemente marcado pela violência da experiência. ${ }^{128}$ (DANIÉLOU, 1987, p. 281-282)

${ }^{127}$ É interessante notar a aparente contradição entre a defesa do politeísmo de Daniélou e a consideração da intensidade da natureza religiosa da cerimônia sufi - ligada portanto ao islamismo que é uma religião monoteísta - descrita aqui. Entendemos que os ataques de Daniélou ao monoteísmo referem-se a característica destas religiões de impor sua visão religiosa ao mundo como se fosse a única verdadeira (exoterismo). A descrição da cerimônia sufi neste caso refere-se à experiência religiosa mais profunda e para iniciados (esoterismo).

${ }^{128}$ Thirty miles from Teheran, at Galand Bagh, the home of the former Iranian Ambassador to Rome, Nizam Sultan Khajenouri, I witnessed the ecstatic ceremonies of the sufis. Like many Iranians who otherwise appear quite modern, Nizam was a sufi and deeply involved in the poetic and mystical tradition which all the greatest Persian poets have belonged to.

The ceremony took place in an isolated building in the garden. Ernest and I were served tea in a comfortable little room furnished with rugs and cushions. Then we slipped through a narrow door into a large adjoining room filled with men sitting on the floor. It was very dark. We sat discreetly in a corner, against a wall. The silence was awesome, overwhelming.

Little by little, almost imperceptibly, a low murmur of prayers seemed to rise from this motionless crowd of bodies. Then someone began to intone a low chant, which the others, still murmuring, took up in unison. The chant grew gradually louder and louder, and more and more rhythmical, until it became almost deafening. A man stood up and began to dance, making a strange animal-like droning sound and head movements which the Greeks used to compare to those of bulls. Then others joined him. The dance became more and more frenetic, the chants gradually changed to shouts. The clamor was fantastic, overwhelming. Drums began to play, giving a tempo to the dance. I felt completely dazed, almost hypnotized. Time and space seemed no longer to exist. The movement and the noise formed a kind of cone that rose to the sky and seemed to communicate with an unknown world. The dancers acted as though they were intoxicated. They went in a trance, shouting and calling out strange incomprehensible words. The droning went faster and faster and became more spasmodic, mingled with invocations to Allah.

This frenzy lasted over an hour. Then the exhausted participants began to fall on the floor, one after another, in a sort of cataleptic fit. The clamor slowly died down, then suddenly ceased altogether. The room looked like a battleground covered with prostrated, motionless heaps of bodies. A blessed silence, like a mysterious presence, descended upon the room, enveloping this victims of the faith. Ernest and I slipped quietly out the door, still completely deafened, still under the spell of our strange experience, the magical act of communication with the unknown we had witnessed: we felt transformed, like different men. We remained for a long time in a quiet and peaceful little room without saying a word to each other, then walked through a lovely rose garden back to the main house.

I have never dared to record the zeckr ceremonies. The religious nature of this kind of experience is far too intense for me to even consider introducing so profane an element as curiosity. Two of my assistants, who 
Titus Burckhardt, em seu livro A arte sagrada no oriente e no ocidente: princípios e métodos, faz uma distinção entre o que chama de arte sagrada, uma arte na qual "não basta que seus temas derivem de uma verdade espiritual. É necessário, também que sua linguagem formal testemunhe e manifeste essa origem" (BURCKHARDT, 2004, p. 17), e o que denomina de maneira geral como arte religiosa, por exemplo, a arte sacra do Renascimento e do Barroco, "que absolutamente não se distingue, enquanto estilo, da arte fundamentalmente profana da mesma época" (BURCKHARDT, 2004, p. 17).

$\mathrm{Na}$ experiência vivida por Daniélou no ritual sufi relatado acima, nota-se que a cerimônia possui uma determinada sequência de acontecimentos, um aspecto formal, que segundo a definição de Burckhardt, é o que garante o testemunho e a manifestação de sua origem espiritual. Porém Burckhardt entende que tais aspectos formais devem estar presentes também numa arte que se pretenda sagrada, e não meramente portadora de um caráter ou tema religioso.

Para Burckhardt "toda forma transmite determinada qualidade de ser. [...] Há, pois, obras de arte essencialmente profanas de temas sagrados, mas não pode haver obra sagrada de formas profanas, já que existe uma analogia rigorosa entre a forma e o espírito" (BURCKHARDT, 2004, p. 18).

Por sua vez, Daniélou, em seu texto La théorie métaphysique du verbe et son application dans le langage et la musique, afirma que "a origem do pensamento e da matéria é uma e pode remeter-se a um movimento ou estado vibratório que é uma particularização local do imenso continuum que é o Ser Indiferenciado"129 (DANIÉLOU, 2007), acrescentando também que

A vibração-som é uma relação ou ritmo que é ao mesmo tempo ideia e forma sensível. Ela é o laço que une pensamento e sua materialização substancial. Ela é como a equação numérica que permite analisar a ideia e a substância e que pode ser então abordada tanto de um lado como de outro como aquilo que aparece no som musical, que pode ser percebido como uma expressão ou ideia ou como uma relação de vibrações físicas. ${ }^{130}$ (DANIÉLOU, 2007)

were less personally involved, succeed in doing this: one in Syria, the other in Yugoslavia, among Moslems of Albanian origin. I was able to produce two superb recordings of these ceremonies. Jochen Wenzel, a skillful young technician who accompanied the researchers, was strongly marked by the violence of the experience.

${ }^{129}$ l'origine de la pensée et celle de la matière est une et peut être ramenée à un mouvement ou état vibratoire qui est une particularisation locale de l'immense continuum qu'est l'Etre Indifférencié.

${ }^{130}$ La vibration-son est un rapport ou rythme qui est à la fois idée et forme sensible. Elle est le lien qui unit la pensée et sa matérialisation substantielle. Elle est comme l'équation numérique qui permet d'analyser l'idée et la substance et peut donc être approchée d'un côté comme de l'autre comme cela apparaît 
Há então para Daniélou, uma relação inseparável entre ideia e forma, ainda que se possa percebê-las de maneira individualizada. De certa maneira é como percebemos o som, que embora seja possível abstrair parâmetros como altura, duração, intensidade e timbre, de forma que possamos analisá-los de maneira independente, nunca é possível realizá-lo de forma que exista apenas como um destes parâmetros independente dos outros.

Além disso, o som está presente na música e na fala - que Daniélou denomina som articulado. Notamos ainda uma concepção metafísica da linguagem, seja ela musical ou falada, quando Daniélou afirma que "as divisões do som musical e do som articulado são paralelas e interdependentes. A música, como a linguagem, é um meio de exprimir sentimentos, ideias e imagens por meio dos sons"131 (DANIÉLOU, 2007).

Daniélou especifica melhor a diferença entre música e linguagem falada:

As divisões do som musical são similares àquelas do som articulado mas se encontram mais próximas da vibração original, do Nâdâ. Seu sentido é então mais geral, menos particularizado que aquele dos sons articulados e representa as leis gerais de expressão pelos sons das quais a linguagem articulada é um caso especial. [...] Por isso a música é associada com os Gândharvâs ou músicos celestes, cujo nome é também conectado com a noção de odor (gandhà) porque as ideias ou emoções são levadas diretamente pelos sons musicais como um perfume pela brisa, sem intermediário de análise. ${ }^{132}$ (DANIÉLOU, 2007)

e conclui afirmando que "a música tem então, um lugar todo especial no ritual e é de fato uma das vias mais diretas para alcançar a experiência mística e o conhecimento"133 (DANIÉLOU, 2007).

Apesar desta concepção metafísica e das afirmações de que a música transmite ideias e sentimentos, ou seja, uma concepção que negaria o valor autônomo da arte musical, ela é diferente da concepção romântica da expressão dos sentimentos, ou da Doutrina dos Afetos do período Barroco. Sua ideia estaria mais próxima do ethos grego, em que cada modo seria

particulièrement dans le son musical qui peut être perçue comme une expression ou idée ou comme un rapport de vibration physiques.

${ }^{131}$ Les divisions du son musical et du son articulé sont parallèles et interdépendantes. La musique comme le langage est un moyen d'exprimer des sentiments, des idées, des images par les sons.

${ }^{132}$ Les divisions $d u$ son musical sont similaires à celles $d u$ son articulé mais restent plus proches de la vibration originelle, de Nâdâ. Leur sens est donc plus général, moins particularisé que celui des sons articulés et représente les lois générales d'expression par les sons dont le langage articulé est une application spéciale.

[...] C'est pourquoi la musique est associée avec les Gândharvâs ou musiciens célestes dont le nom est aussi connecté avec la notion d'odeur (gandhà), car les idées ou émotions sont apportées directement par les sons musicaux comme un parfum par la brise sans l'intermédiaire d l'analyse.

${ }^{133}$ La musique a donc une place toute spéciale dans le rituel et est en fait une des voies les plus directes pour atteindre à l'expérience mystique et à la connaissance. 
descrito menos por sua coleção e arranjo de notas e sim pelos estados emocionais que podem suscitar (DANIÉLOU, 2007).

Por isso é possível entender as aparentes contradições expressas em suas opiniões a respeito da música contemporânea. Em seu texto L'Agression harmonique, em que critica os desenvolvimentos seguidos pela música ocidental a partir da adoção da harmonia e do temperamento igual, fazendo uma defesa da música modal e das afinações naturais, afirma que o desenvolvimento harmônico ocidental, que se infiltrou em praticamente todas a culturas, foi minado em seu próprio terreno, e entende como positivo os trabalhos dos "precursores" Schoenberg, Webern, Satie, Stravinsky, Ives e dos "profetas" Cage e Stockhausen, pois possibilitaram uma nova música e consequentemente uma nova escuta, que não era mais dependente da teleologia harmônica tonal, e então as músicas orientais puderam ser aceitas e ouvidas não mais como manifestações primitivas, pois destituídas do dado harmônico, mas a partir daquilo a que elas se propunham a enfatizar (DANIÉLOU, 2005b, p. $70)$.

Depois afirma que a música moderna não pode reecoar a harmonia das esferas pois perdeu sua dimensão cosmológica, "mas em sua busca por nova vocação, curiosamente, reverteu-se num tipo de animismo"134 (DANIÉLOU, 1987, p. 252). Ao absorver os sons do ambiente, buzinas, murmúrios de rio, cantos de pássaros, Daniélou entende que "para ser entendida, contudo, música deste tipo necessita um suporte visual e representação"135 (DANIÉLOU, 1987, p. 252).

E então comenta que

a música vital de nosso tempo é o jazz, o rock, a disco, a canção popular. O que as pessoas chamam de música moderna, frequentemente composições abstratas completamente destituídas de significado acústico ou psicológico, interessa apenas um pequeno grupo de amantes condicionados da música. $\mathrm{Eu}$, por exemplo, acho mortalmente entediante. Hoje em dia mesmo as obras-primas da música romântica são muitas vezes tocadas friamente, precisamente, sem pensar em nada a não ser na técnica. ${ }^{136}$ (DANIÉLOU, 1987, p. 315)

Conclui-se que a música que busca Daniélou é aquela que não se apoie apenas em dados puramente racionais - embora em seus estudos os intervalos sejam analisados desta

\footnotetext{
${ }^{134}$ But in his search for a new vocation, oddly enough, it has reverted to a kind of animism.

${ }^{135}$ In order to be understood, however, music of this kind needs a visual support and representation.

${ }^{136}$ The vital music of our time is jazz, rock, disco, the popular song. What people call modern music, most often abstract compositions completely devoid of acoustical or psychological meaning, only interests a small group of conditioned music lovers. I, for one, find it deadly boring. Nowadays even the masterpieces of romantic music are too often played coldly, precisely, with no thought for anything but technique.
} 
maneira -, mas sim uma música que possa atingir o ouvinte em diversos níveis: espiritual, emocional e até mesmo racional 


\section{Como?}

Daniélou comenta que quando conheceu o crítico musical Maurice Fleuret tornaram-se bons amigos, embora discordassem em tudo. "Nossas conversas sempre foram interessantes e úteis para mim, porque elas me faziam notar que uma obra de arte pode ser julgada e apreciada de pontos de vistas totalmente opostos e de acordo com diferentes sistemas de valores" (DANIÉLOU, 1987, p. 306).

Embora não abra mão de suas crenças e concepções, como é possível notar em seus textos, Daniélou entende que seu ponto de vista pode não ser o único possível, e que mesmo a ideia de uma única verdade não se mantém como uma possibilidade real e concreta:

Quer alguém esteja falando de geometria euclidiana, teorias pitagóricas da música, ou mesmo interpretações históricas ou simbólicas, todos os sistemas de pensamento são falsos quando levados a extremos. Não se deve nunca esquecer que nenhuma explicação da criação do mundo e do destino do homem jamais poderá ser mais do que relativa; a realidade última nunca pode ser conhecida. Há sempre uma linha tênue entre uma concepção cosmológica da criação e evolução e sua real aplicação. O momento em que a verdade é tomada como dogma, torna-se falsa. ${ }^{137}$ (DANIÉLOU, 1987, p. 146)

No entanto, não se pode afirmar a partir destas colocações que Daniélou seja um relativista. Daniélou parte de um determinado ponto de vista, de um determinado sistema de valores, para daí construir os argumentos que embasam as hipóteses por ele formuladas.

Tal sistema de valores, ou "pontos de vista" (darshana), vistos no início no subcapítulo 2.4 Música e metafísica em Daniélou, identifica-se com aquilo que no ocidente chamamos de metodologia, permitindo uma visão ampliada do objeto e do processo de pensamento, o que possibilita uma abertura epistemológica do sujeito em relação ao assunto a ser abordado.

No primeiro capítulo 1. Por que?, afirmamos na página 21: "Uma pesquisa sobre uma pesquisa deve ser uma metapesquisa, algo além da pesquisa, uma pesquisa que pesquise o próprio ato de pesquisar, assim como a metalinguagem fala da própria linguagem."

\footnotetext{
${ }^{137}$ Whether one is talking of Euclidian geometry, Pythagorean theories of music, or even historic or symbolic interpretations, all systems of thought are false when carried to extremes. One should never forget that no explanation of the world's creation and man's destiny can ever be more than relative; the ultimate reality can never be known. There is always a thin line between a cosmological conception of creation and evolution and its actual application. The moment of truth is taken as dogma, it becomes false.
} 
Colocam-se então algumas questões a partir destas afirmações.

Como desenvolver um referencial metodológico que possibilite investigar não só o caminho desenvolvido para a construção das hipóteses propostas por Alain Daniélou em seus trabalhos, mas que também possa atualizar seu sentido e explicá-las em outra chave que não o campo de estudos da Etnomusicologia, e de forma que não seja caracterizado como um mero ecletismo?

Como interpretar as afirmações de Daniélou, de maneira a contemplar também o sistema de pensamento indiano, que ele afirma basear-se em seis métodos cujas conclusões toleram inclusive contradições?

Como analisar o trabalho de Daniélou considerando-o mais como uma proposição, uma contribuição para o desenvolvimento de uma nova possibilidade criativa no domínio musical, do que uma sistematização de uma música já existente, ainda que para isso seja preciso entender, assimilar e interpretar as afirmações, dados históricos e suposições por ele formuladas?

Retomando Langer, e o que ela diz a respeito da condição limitada e limitadora que qualquer pergunta possui, as perguntas acima carregam já em si limitantes para suas respostas, de forma que o que é possível responder já está dentro do campo de possibilidades aberto (ou seria mais preciso dizer fechado?) pelas perguntas.

Uma nova questão então se coloca: como estender o horizonte de compreensão dos estudos empreendidos por Daniélou, sem cair na armadilha da limitação imposta pela formulação das perguntas?

Alguns autores fornecem pistas que possibilitam ampliar os limites impostos pela natureza das perguntas.

Richard Rorty em seu texto Gadamer e sua utopia, comenta uma frase famosa de Gadamer: "O ser que pode ser compreendido é linguagem” (GADAMER, 1997, p. 687). Os comentários desenvolvidos por Rorty sobre esta frase, abrem possibilidades de entender o sistema utilizado por Daniélou para disciplinar seu pensamento - os seis métodos indianos, porém partindo de um ponto de vista ocidental.

A frase de Gadamer é interpretada por Rorty como

uma redescrição do processo que chamamos "aumentar nossa compreensão". Dos gregos até nós, esse processo foi descrito geralmente com a ajuda de metáforas falocêntricas de profundidade. Quanto mais profunda e penetrante nossa compreensão de algo, assim dizem, mais afastados estamos da aparência e mais perto da realidade. Adotar o lema de Gadamer tem como efeito substituir essas metáforas de profundidade por metáforas de 
amplitude: quanto mais descrições estiverem disponíveis e quanto maior a integração entre elas, melhor nossa compreensão do objeto identificado por qualquer dessas descrições. (RORTY, 2008, p. 3 destaque do autor)

Entendemos que, a despeito do caráter metafísico presente no sistema indiano, podemos traçar um paralelo entre as redescrições propostas por Rorty e o entendimento a partir de diversos pontos de vista utilizado por Daniélou, que por vezes podem chegar em resultados contraditórios entre si. Há uma ampliação inevitável do entendimento do objeto estudado, e, mais do que isso, possivelmente a fronteira entre sujeito e objeto possa se apresentar mais tênue do que podemos supor.

É possível então afirmar que os estudos de Daniélou, mais do que dar uma resposta definitiva às questões etnomusicológicas, históricas ou a respeito da significação musical, contribuem para aumentar a compreensão do que seja música, não só a música oriental, mas a própria música ocidental.

Se analisarmos tais estudos como interpretações ou redescrições possíveis do fenômeno musical, estaremos sendo coerentes não só com o sistema de pensamento por ele utilizado, mas também com suas próprias afirmações a respeito da incognoscibilidade da realidade última e da falsidade da verdade tomada como dogma; além disso concordaríamos com o que Kuhn aponta a respeito dos paradigmas científicos, e que Vattimo atribui especialmente às artes: a persuasão e convencimento retóricos têm um papel preponderante na consolidação de um paradigma, seja ele artístico ou científico.

Não se está aqui defendendo um ponto de vista relativista, em que todas as interpretações tenham o mesmo valor, mesmo porque o contexto colocará em perspectivas diferentes cada uma dessas interpretações, o que se busca é o direito à existência da reflexão, o direito à existência do máximo de possibilidades interpretativas, sendo a de Daniélou uma delas, cuja raiz é possível identificar, mas cujos frutos podem surgir onde e quando menos se espera.

Esta leitura de Gadamer feita por Rorty é útil pois nos possibilita entender as pesquisas de Daniélou como redescrições possíveis que permitem ampliação da compreensão da música para além do aspecto etnomusicológico há muito identificado com seu trabalho. Outras disciplinas e outros campos de estudo que contemplem o fenômeno musical em seus processos investigativos serão beneficiados com as reflexões propostas.

Com relação aos aspectos metafísicos das reflexões propostas por Alain Daniélou em seus trabalhos musicológicos, nota-se que esses aspectos, tais como os embasamentos matemáticos da construção de sua escala e da interpretação da significação musical, que por 
serem matemáticos pressupõem respostas únicas e exatas, não separam de maneira peremptória essência e aparência, sujeito e objeto, significante e significado, como comumente se espera desse tipo de reflexão.

Considerando a escala universal dos sons proposta por Daniélou em seus trabalhos tanto dos pontos de vista étnico e histórico, presentes no Traité de musicologie comparée, quanto do ponto de vista da significação musical, apresentados em Sémantique Musicale -, que pretende unificar a construção escalar cíclica e a construção por harmônicos e é formada por relações numéricas que determinam as suas relações intervalares, é possível associá-lo a uma corrente de pensamento neopitagórica, uma vez que a busca de tal unificação se dá como um desejo de encontrar os princípios metafísicos dos sons. Porém em Daniélou tal associação se dá com uma particularidade que o diferencia e torna simplificadora uma associação direta, necessitando de uma análise mais detalhada.

O filósofo Giovanni Piana em seu texto La scala dei suoni di Daniélou, afirma que

a posição de Daniélou é exemplar pelo fato de que se regride, em relação ao problema de uma fundação objetivista, do fisicalismo ao aritmetismo, realizando em certo sentido às avessas o caminho que conduz do ponto de vista aritmetizante, que era afirmado a partir da cultura grega até o Renascimento tardio e além, para a fundação na física do som. ${ }^{138}$ (PIANA, 2003, p. 28, destaque do autor)

Com tal afirmação, ele aponta a singularidade do processo de pensamento no qual se baseia a construção da escala de Daniélou que o difere das correntes aritmetizantes, visto que ele parte do elemento físico para encontrar a justificação matemática e não da concepção matemática que busca o elemento físico.

Piana explica que

O ponto de vista aritmetizante tende a separar o número da realidade corpórea, e por isso a considerar o número em si mesmo como princípio do real, abrindo-se a toda sorte de especulação filosófica sobre as virtudes dos números como tal. ${ }^{139}$ (PIANA, 2003, p. 28)

Deste modo, ao diferir-se do pensamento aritmetizante, Daniélou proporciona outra

\footnotetext{
${ }^{138}$ La posizione di Daniélou è esemplare per il fatto che si regredisce, in rapporto al problema di una fondazione oggettivistica, dal fisicalismo all 'aritmetismo, compiendo in certo senso a ritroso il cammino che conduce dal punto di vista aritmetizzante che si era affermato a partire dalla cultura greca fino al tardo rinascimento ed oltre, alle fondazioni nella fisica del suono.

${ }^{139}$ Il punto di vista aritmetizzante tende a separare il numero dalla realtà corporea, e proprio per questo a considerare il numero in se stesso come principio del reale, aprendosi ad ogni sorta di speculazione filosofica sulle virtù dei numeri come tali.
} 
interpretação da relação possível entre som e relações numéricas, pois

quando, por sua vez, a relação numérica vem atribuída à vibração de um corpo elástico e ocorre assim o reencontro do número com o elemento físico, as considerações metafísicas vão para segundo plano, a numerologia interessa muito menos do que interessa uma possível análise da constituição interna do som como evento da natureza. E todo o problema tende a particularizar-se, afrouxando-se os laços com os fenômenos não pertencentes à música que anteriormente poderiam ser mantidos em relação estreita com a analogia numérica. ${ }^{140}$ (PIANA, 2003, p. 29, destaques nossos)

Nota-se então que, embora as considerações metafísicas ainda estejam presentes, ao cair para segundo plano, elas deixam de ter uma importância fundamental, abrindo a possibilidade de uma interpretação fenomenológica dos sons, e não apenas matemática.

Daniélou não despreza o dado sensível do som, o que lhe permite afirmar que os teóricos indianos confiam mais na identificação dos intervalos pelas sensações e sentimentos por eles evocados do que pelo cálculo matemático, e lhe dá inspiração para escrever o livro Sémantique Musicale.

Em sua autobiografia comenta que certa vez fez uma estimativa de que era “qualificado para a prática de 32 diferentes ofícios e profissões" "141 (DANIÉLOU, 1987, p. 330), e que isto se deve ao fato de que ele

sempre procurou pelos vínculos secretos entre todos os diferentes aspectos do mundo, princípios comuns à música, linguagem, arquitetura, mas também à harmonia física dos seres vivos - plantas, animais e homens, [...] [pois] o corpo e o espírito são mais intimamente ligados do que imaginamos. ${ }^{142}$ (DANIÉLOU, 1987, p. 331)

Esta pluralidade de habilidades desenvolvidas por Daniélou o coloca numa categoria especial de estudioso. Podemos compará-lo com os grandes sábios do passado, personalidades que também exerciam diversas atividades. Uma época específica na história do pensamento ocidental propiciou o florescimento de conhecimentos diversos, em virtude principalmente do

\footnotetext{
${ }^{140}$ Quando invece il rapporto numerico viene attribuito alle vibrazioni di un corpo elastico ed avviene così la ricongiunzione del numero con l'elemento fisico, le considerazioni metafisiche regrediscono sullo sfondo, la numerologia interessa assai meno di quanto interessi una possibile analisi della costituzione interna del suono come evento della natura. E l'intero problema tende a particolarizzarsi, allentandosi i legami con $i$ fenomeni non appartenenti alla musica che in precedenza potevano essere tenuti stretti con analogie numerologiche.

${ }^{141}$ Qualified to practice thirty-two different trades and professions.

${ }^{142}$ Always searched for secret links between all different aspects of the world, principles common to music language, architecture, but also to the physical harmony of the living being - plants, beasts, and men. [...] [because] The body and the spirit are more closely linked than we realize.
} 
que identificamos com o deslocamento da visão de mundo teocêntrica para a valorização do humano.

O Renascimento foi esta época, em que a imaginação e a criação estavam em alta, assim como a progressiva valorização da individualidade, principalmente a partir de Veneza. Foi a época das grandes navegações e descobertas e da criação da imprensa.

Como afirma o filósofo Paulo Ghiraldelli Junior, “o Renascimento proporcionou antes uma arte expressivamente filosófica do que uma filosofia da arte. De certo modo, é correto dizer que a filosofia do Renascimento se fez, em grande parte, pelos seus artistas" (GHIRALDELLI JUNIOR, 2010, p. 21). Além disso, “os intelectuais renascentistas tinham a pretensão de ser indivíduos integrais, e vários deles assim se fizeram a partir do modo como foram educados", com “o currículo de estudos baseado em Gramática, Retórica, Poesia, História e Dialética ou Filosofia" (Ibidem, p. 15). E ainda, "se a modernidade de Descartes pode ser vista como a época da ciência e da exatidão, o tempo de Montaigne é o do gracejo e da imaginação" (Ibidem, p. 10).

Se entendermos Daniélou como um indivíduo integral, qualificado para 32 atividades, amante das artes, que tenta se expressar com elas e através delas mesmo quando se trata de trabalhos científicos ou filosóficos, e que segundo nossa interpretação, deixou um trabalho que consideramos profundamente imaginativo e que possibilita aberturas para novas criações musicais e que, além disso, ele mesmo afirma que sua proposta de trazer ao Ocidente a herança cultural indiana, a única civilização antiga a sobreviver, possibilitaria ao pensamento moderno experimentar um novo Renascimento, os paralelos entre ele e o intelectual renascentista ficam mais e mais evidentes. Porém, apesar desta característica renascentista, veremos no capítulo 1. Filosofia da Música da Parte 2, que seu pensamento e maneira de abordar a música e a arte aproximam-se mais do modo de pensar medieval.

Sendo assim, resta entender como o pensamento de Daniélou pode se articular com outras disciplinas e campos de estudo.

Ao pesquisar e nos apresentar os estudos relativos às músicas orientais, Daniélou opta por não partir da observação destas músicas enquanto obras de arte. Busca um ponto comum em que possa analisá-las de forma a abstrair um pensamento subjacente que possibilite ao mesmo tempo colocá-las em diálogo com a música ocidental tal como se desenvolveu nestes séculos de tonalismo.

Daniélou toma como seu objeto de estudo a teoria destas diversas músicas, e em seu Traité de Musicologie Comparée justifica assim esta opção: 
Muitas vezes podemos descobrir equivalência de formas musicais que parecem não ter nada em comum e diferenças profundas entre os sistemas que nos parecem, à primeira vista, como semelhantes. Através da teoria, julgamos os sistemas musicais em bases sólidas. Compreender a sua beleza e perceber diretamente o seu significado é outro assunto e requer geralmente um longo hábito. ${ }^{143}$ (DANIÉLOU, 2004, p. 25)

Acrescenta ainda que existiria a tentação no ocidente de entender a música oriental e suas relações intervalares como sendo fenômenos de outra natureza, como se a utilização de tais relações se dessem em virtude do entendimento diferenciado do fenômeno acústico. Para corroborar sua opção pela teoria musical, Daniélou afirma que os diferentes intervalos utilizados no Ocidente ou no Oriente "referem-se aos mesmos princípios acústicos. Consequentemente a diferença emerge, seja da prática musical em contradição com a teoria, ou do uso de apenas algumas das possibilidades abertas pelos princípios comuns"144 (DANIÉLOU, 1995, p. 10).

Ele entende que "estes diferentes sistemas musicais não se opõem um ao outro. Ao contrário, eles se complementam, pois todos nascem necessariamente das mesmas leis fundamentais das quais eles exploram diferentes aspectos"145 (DANIÉLOU, 1995, p. 10). Por tais motivos, Daniélou evita, portanto, a avaliação direta de obras musicais, que são objetos de estudo tanto da musicologia histórica quanto da etnomusicologia, e que, no caso da última, acrescentaria ainda o trabalho de campo antropológico. Abordaremos de maneira mais ampliada a forma como Daniélou entende a teoria musical no capítulo 2. Teoria musical da

\section{Parte 2.}

Esta opção pela teoria, e não pela análise direta de obras musicais, mostra o ponto chave em que é possível diferenciar os estudos de Daniélou. É evidente que se trata de uma opção metafísica, porém ao invés de entender tais estudos como uma Etnomusicologia ainda eivada de pressupostos positivistas, que claramente a afasta dos rumos posteriores tomados por este campo de estudos, é possível aproximá-lo de outras áreas.

É plenamente possível encontrar justificativas para entendermos a obra de Daniélou a partir da teoria musical, não só do ponto de vista da filosofia, como veremos abaixo com

\footnotetext{
${ }^{143}$ Nous pourrons souvent découvrir l'équivalence de formes musicales qui semblent n'avoir rien en commun, ainsi que des différences profondes entre des systèmes qui nous apparaissent au premier abord comme similaires. A travers leur théorie, nous jugerons les systèmes musicaux sur des bases solides. Comprendre leur beauté ou percevoir directement leur signification est une autre affaire et exige en général une longue habitude.

${ }^{144}$ Refer to the same acoustic principles. Hence the difference can only come either from a musical practice in contradiction to theory, or from the use of only some of the possibilities opened up by those common principles.

${ }^{145}$ These different musical systems do not oppose one another. On the contrary, they complete each other, as they all spring necessarily from the same fundamental laws of which they exploit different aspects.
} 
respeito à definição gadameriana a respeito da relação entre os termos teoria e filosofia, mas também do ponto de vista musical.

Embora o título de um de seus principais livros sobre música seja Traité de musicologie comparée (Tratado de musicologia comparada), que como sabemos era o nome anterior do campo de estudos que veio a ser conhecido como Etnomusicologia a partir da introdução do termo na década de 1950 por Jaap Kunst (KERMAN, 1987, p. 219), além do fato de ele mesmo assumir que utiliza a teoria como elemento unificador de sua análise, vemos que algumas observações de Kerman a respeito da teoria musical são pertinentes para a possibilidade de se compreender a obra de Daniélou nesse campo.

Kerman comenta no início de seu livro Musicologia, não sem certo cuidado, que "a teoria se ocupa daqueles aspectos da música que se poderiam considerar análogos no campo da linguagem, do vocabulário, da gramática, sintaxe e retórica" (1987, p. 4). Embora Daniélou esteja abordando a música não ocidental, não se furta a usar termos como linguagem para a música e vocabulário para os intervalos musicais. Além disso, como também aponta Kerman, "alguns deles inclinam-se para a filosofia, e outros escrevem ensaios numa linguagem autogerada tão altamente especializada quanto a da lógica simbólica" (1987, p. 5). Ainda que a linguagem das obras de Daniélou não seja tão autogerada, é preciso certo conhecimento técnico musical para entender as minúcias de seu raciocínio, pois cria uma escala de 53 sons por oitava e um sistema de notação que acreditava representar com maior precisão matemática as relações numéricas entre os seus intervalos.

O filósofo Hans-Georg Gadamer, citado acima tal como visto por Richard Rorty, pode nos oferecer mais uma vez uma possibilidade de abertura para o entendimento do pensamento de Alain Daniélou, desta vez em sintonia com as observações de Kerman sobre a teoria musical. Em seu texto Elogio da Teoria nos mostra que a palavra teoria entre outras possibilidades interpretativas, tem a ver com observação, contemplação e especulação, o que leva sua definição a ser a própria definição de filosofia, e que esta, na verdade, seria "o antigo nome para teoria" (GADAMER, 2001, p. 23 et seq.).

Por sua vez tanto Dahlhaus quanto Godwin, afirmam a existência do que se pode chamar de Teoria Especulativa da música, respectivamente como "contemplação ontológica dos sistemas sonoros"146 (DAHLHAUS apud CHRISTENSEN, 2004, p. 13) e que "o músico especulativo descobre princípios universais tão seguramente quanto o matemático ou o filósofo" "147 (GODWIN, 1992, p. 271). Pode-se afirmar que são estas as principais

\footnotetext{
${ }^{146}$ ontological contemplation of tone systems

${ }^{147}$ The speculative musician discovers universal principles as surely as the mathematician or the philosopher
} 
características presentes em Alain Daniélou, como vimos acima nas seções relativas às suas obras.

Daniélou considera ainda, que

a conexão entre a realidade física e os princípios metafísicos pode ser sentida na música como em nenhum outro lugar. A música era, portanto, justamente considerada pelos antigos como a chave para todas as ciências e artes - a ligação entre metafísica e física através da qual as leis universais e suas múltiplas aplicações poderiam ser entendidas ${ }^{148}$ (DANIÉLOU, 1995, p. 1),

e afirma que

a maior parte dos elementos de nosso sistema musical são relacionados a uma teoria cosmológica milenar e a um simbolismo muito antigo, como são também as raízes e formas de linguagem, instrumento de nosso pensamento, assim como muitas das nossas formas de medir o tempo e o espaço. ${ }^{149}$ (DANIÉLOU, 2004, p. 15 destaque nosso)

Mais uma vez podemos aproximar os estudos de Daniélou de uma reflexão mais filosófica que científica, pois o que ele considera como conexão entre realidade física e metafísica pode se apresentar como um simbolismo, e como observa Susanne K. Langer em Filosofia em nova chave,

na noção fundamental de simbolização - mística, prática, ou matemática, não faz diferença - temos a tônica de todos os problemas humanísticos. Nela, reside a nova concepção de "mentalidade", que ilumina questões de vida e consciência, em vez de obscurecê-las, como fizeram os "métodos científicos" tradicionais. [...] O estudo filosófico dos símbolos não é uma técnica tomada a outras disciplinas, nem sequer da matemática; surgiu nos campos que o grande avanço do saber deixou abandonado. Talvez contenha a semente de uma nova colheita intelectual a ser ceifada na próxima estação do entendimento humano. (LANGER, 1971, p. 35 destaques da autora)

Retomando duas citações de Daniélou, feitas por José Miguel Wisnik e Jorge Antunes, apresentadas respectivamente nas páginas 16 e 17 no capítulo 1. Por que?, vemos que a obra de Daniélou, principalmente seu livro Sémantique Musicale, se aproxima também dos estudos

\footnotetext{
${ }^{148}$ The connection between physical reality and metaphysical principles can be felt in music as nowhere else. Music was therefore justly considered by the ancients as the key to all sciences and arts - the link between metaphysics and physics through which the universal laws and their multiple applications could be understood.

${ }^{149}$ La plupart des éléments de notre système et de notre vocabulaire musical sont liés à une théorie cosmologique millénaire et à un très ancien symbolisme comme le sont aussi les racines et las formes du langage, instrument de notre pensée, ainsi que beaucoup de nos manières de mesurer le temps et l'espace.
} 
de Cognição Musical.

José Miguel Wisnik nos apresenta a ideia do ritmo alfa como sendo um ritmo que regularia todos os nossos outros ritmos biológicos, além da questão da fadiga mental que seria proporcionada pela audição de uma música executada em um instrumento afinado de acordo com o Temperamento Igual; enquanto Jorge Antunes comenta a respeito do efeito festa, a possibilidade de concentrar nossa atenção em alguma fonte sonora, a despeito de estarmos em um lugar ruidoso, desde que os sons emitidos por essa fonte sonora se conectem de maneira lógica e inteligível.

Tais referências, extraídas de Sémantique Musicale, apontam tanto para o modo como a música é assimilada por nosso cérebro, quanto para a interpretação que nossa mente pode fazer dessa mesma música. Esta abordagem pode ser encontrada em várias áreas ligadas ao estudo do cérebro e da mente.

Segundo Gardner, integrariam de maneira interdisciplinar as Ciências Cognitivas: a Filosofia, a Linguística, a Antropologia, as Neurociências, a Psicologia e a Inteligência Artificial (GARDNER, 2003, p. 52). A partir desta referência, podemos considerar como áreas específicas com relação à música: a Cognição Musical, a Psicologia da Música, a Musicologia Cognitiva, a Neuromusicologia, a Musicologia Sistemática e a Filosofia da Música.

Com relação à significação ou significado musical, pode-se dizer que este sempre foi um tema caro aos estudos musicais, com diversos autores tentando abordá-lo de diferentes maneiras.

Em Sémantique Musicale, Daniélou opta por entender a música como possuindo significados que poderiam ser considerados universais, a partir dos intervalos ouvidos, e sempre utilizando como ponto de referência a música indiana, pois considera que as diversas tradições musicais são complementos de um mesmo princípio acústico (DANIÉLOU, 1995, p. 10).

A questão dos universais na música é abordado por Leonard B. Meyer no texto $U n$ universo de universales publicado originalmente em 1998, que afirma que sua premissa é simples: "não se pode compreender e explicar a variabilidade das culturas humanas enquanto não se tenha uma apreciação das constantes envolvidas em sua formação"150 (MEYER, 2001, p. 233) e conclui que é necessário reconhecer a existência de universais, "porque somente podemos construir uma estética coerente e uma história da música viável atendendo tão

\footnotetext{
${ }^{150}$ No se puede comprender y explicar a variabilidad de las culturas humanas mientras no se tenga una apreciación de las constantes implicadas en su formación
} 
escrupulosamente a natureza quanto a cultura"151 (MEYER, 2001, p. 257).

Também Enrico Fubini, no texto Individualidade ou universalidade da linguagem musical? publicado originalmente em 1999, ou seja na mesma época que Meyer, aborda a questão dos universais. Depois de um breve histórico, ele conclui seu texto de forma semelhante a Meyer, afirmando que "individualidade e universalidade, ou, se quiserem, historicidade e naturalidade, não parecem termos inconciliáveis de uma antítese radical, mas antes polaridade em que pólos intimamente se implicam um ao outro" (FUBINI, 2001a, p. 118).

Observa-se nestes dois autores a consideração a respeito dos dados culturais ou históricos e naturais, e que portanto uma determinada significação musical deveria dar conta em maior ou menor grau destes dois âmbitos.

Por sua vez, Jean-Jacques Nattiez em seu texto Etnomusicologia e significações musicais, afirma que “em cada cultura, as associações semânticas resultam de hábitos e convenções, o que não significa que a ligação entre significante e significado [...] não seja iconicamente motivada pelas características imanentes do significante" (NATTIEZ, 2004, p. 26).

A partir das informações a respeito do significado e dos universais em música abordados acima, retoma-se a questão da Cognição Musical como um campo de estudos possível de funcionar como um quadro teórico para o entendimento dos estudos de Daniélou, de forma a contemplar também as afirmações formuladas acima por Meyer, Fubini e Nattiez.

Nosso objetivo nesse caso será entender em que medida é possível abstrair da literatura existente a hipótese de uma significação universal da música, proposta por Daniélou, e em que medida esta significação estaria de fato ligada com algum tipo de relação entre o dado sensível da relação intervalar e o dado intelectual da relação matemática que representa os intervalos.

Como aponta Kerman, originalmente a palavra musicologia designava todo e qualquer estudo sobre a música $(1987$, p. 1). A partir deste dado, Beatriz Senori Ilari, em seu texto Cognição musical: abordagens tradicionais, direções futuras - uma bela revisão bibliográfica sobre a área da Cognição Musical - estabelece uma aproximação entre as duas áreas, afirmando que

como não poderia deixar de ser, o estudo da cognição musical é uma das

\footnotetext{
${ }^{151}$ Porque solamente podremos construir una estética coherente y una historia de la música viable atendiendo tan escrupulosamente a la naturaleza como a la cultura
} 
especializações da musicologia na definição ampla do termo, isto é aquela que abrange todos os contextos e metodologias possíveis ao estudo da música. (ILARI, 2010, p. 12)

Após tomar a musicologia sistemática como ponto de referência, afirma que nos "tempos atuais a pesquisa musicológica que tem por base o estudo da cognição musical frequentemente converge para um mesmo ponto onde se encontram também as pesquisas da psicologia da música" (ILARI, 2010, p. 18), e que "desde 1990, a área da psicologia da música tem se tornado ainda mais ampla e uma forte ênfase tem sido dada ao estudo do cérebro musical e das emoções associadas à música" (ILARI, 2010, p. 25). Conclui (Ibidem, p. 31) citando Daniel Levitin que afirma que "o estudo científico da música é potencialmente apto a responder algumas questões fundamentais sobre a natureza do pensamento humano e as relações entre experiência, mente, cérebro e genes". (LEVITIN, 2006, p. 44)

Nota-se portanto, que a abordagem da obra de Daniélou por meio da cognição musical poderá ser de grande contribuição para seu entendimento, pois assim como Daniélou parte do princípio de que as relações entre notas, que formam intervalos, são apreendidas pelo nosso aparelho áudio-mental, que funciona como um computador processando informações, assim também observa Levitin ao afirmar que

\begin{abstract}
A maioria dos cientistas e filósofos contemporâneos considera que o cérebro e a mente são duas partes de um todo, e alguns chegam a acreditar que a própria distinção é equivocada. O ponto de vista que hoje prevalece é o de que o conjunto de pensamentos, crenças e experiências é representado em padrões de descargas - atividade eletroquímica - no cérebro. (LEVITIN, 2010, p. 98)
\end{abstract}

Na Parte 2, estenderemos a obra de Daniélou às três áreas abordadas neste capítulo: Teoria da Música, Filosofia da Música e Cognição Musical, proporcionando uma ampliação de seu entendimento por meio do diálogo entre autores das respectivas áreas, detectando assim a contribuição da obra de Daniélou. 


\section{PARTE 2}

IMPLICAÇÕES:

ESTENDENDO ALAIN DANIÉLOU 
Continuamos, nesta Parte 2, desenvolvendo o verbo latino plicare. Acrescenta-se agora o prefixo im, o que nos dá como objetivo a ideia de "dobrar para dentro" ou simplesmente "dobrar", de forma que seja possível, ao dobrar o pensamento de Daniélou, encontrar relações entre seus escritos e outras expressões que não seriam possíveis de outro modo, possibilitando estender, como acrescenta o subtítulo, tais implicações para um diálogo que possibilite ampliar as possíveis interpretações de suas acepções. Nesta segunda parte colocaremos o pensamento de Daniélou em diálogo com a Filosofia da Música - no capítulo 1. Filosofia da Música: Heteronomia; Simbolismo e Matemática - no capítulo 2. Teoria Musical; e Cognição Musical - no capítulo 3. Cognição Musical. 


\section{Filosofia da Música: Heteronomia}

Neste primeiro capítulo da Parte 2, estenderemos os aspectos da obra de Alain Daniélou para colocá-los em diálogo com a Filosofia da Música. Para isso ele foi dividido em três subcapítulos que abordam cada um deles um determinado tópico filosófico ligado à música, que entendemos como próximos das acepções musicais de Daniélou.

Como fio condutor destes tópicos entendemos o aspecto heterônomo que ele atribui à música. Não só porque Daniélou considera a música como uma linguagem, e como tal um veículo para transmissão de informação, mas porque esta informação transmitida é algo além da música, sejam sentimentos, ideias ou emoções.

Podem-se notar tais concepções quando ele se refere à música indiana, a qual estudou não só a teoria quanto a prática instrumental:

o objetivo desta música não é soar bela, mas sim sugerir beleza, modelá-la e criá-la. Ela evoca o esplendor das estações e das horas do dia e da noite, a profundidade dos sentimentos humanos e o poder de suas emoções. Ela abre para nós a porta para os mundos celestiais, mas permanece como verdade. Isto é niranjana, "o não adornado". Não é bela em si. Não é a porta do paraíso que é bela, mas o que alguém vê através dela. As harmonias de formas, cores e sons parecem belos para nós apenas porque elas remetem uma realidade mais elevada. ${ }^{152}$ (DANIÉLOU, 2008a, p. 86)

Além disso Daniélou considera a música do ponto de vista hindu, ou seja, como uma ponte entre os aspectos físicos e metafísicos da realidade. Por isso, não só a música mas as artes em geral "eram consideradas na antiga Índia como o veículo ou instrumento da educação popular"153 transmitindo "na forma de ilustrações e parábolas, os princípios de filosofia, ética e religião, cuja exposição dialética estaria ao alcance apenas de uma minoria cultural"154 (DANIÉLOU, 2008b, p. 91).

Embora possa dar a impressão que, uma vez que a população pudesse ter acesso e entendimento a uma exposição dialética dos princípios de filosofia, ética e religião, a arte, e

\footnotetext{
${ }^{152}$ the purport of this music is not to sound beautiful, but rather to suggest beauty, to shape and to create it. It evokes the splendour of the seasons and of the hours of day and night, the depth of man's feelings, and the power of his emotions. It opens for us the door to the heavenly worlds, but remains like truth, that is niranjana, 'the unadorned'. It is not beautiful in itself. It is not the door of paradise that is beautiful, but what one sees through it. The harmonies of forms, colours, and sounds seem beautiful to us only because they call up a higher reality.

${ }^{153}$ was considered in ancient India as the vehicle or instrument of popular education

${ }^{154}$ in the form of illustrations and parables, the principles of philosophy, ethics and religion, which dialectical exposition would have brought within the reach of only a cultural minority.
} 
neste caso a música, poderia tornar-se inútil, lembramos que Daniélou considera que nenhuma linguagem é capaz de transmitir toda a verdade, e neste caso haveria sempre algo a ser transmitido, seja por motivos quantitativos - da carência de elementos e ou vocabulário de transmissão, seja por motivos qualitativos - a impossibilidade de expressão de uma ideia no seu todo.

A partir dessas considerações iniciais, no primeiro subcapítulo 1.1. Música Especulativa x Especulação Musical trataremos da diferença entre estes dois termos, definindo suas particularidades e de como a obra de Daniélou transita por entre eles. Já publicamos uma breve comunicação sobre este assunto (CINTRA, 2012), mas cabe aqui uma maior ampliação para que seja possível uma descrição mais abrangente, que devido às limitações de publicação não foi possível realizar na referida comunicação.

No segundo subcapítulo 1.2. Música sagrada $x$ sacralização da música trataremos das diferenças entre o que definimos como Música Sagrada, baseando-nos na obra $A$ arte sagrada no oriente e no ocidente de Burckhardt (2004), e o que observamos como sacralização da música, um fenômeno que se dá principalmente a partir do Romantismo, mas que influencia o pensamento musical até os dias de hoje.

O terceiro subcapítulo, 1.3. Ethos, afetos e sentimentos, será dedicado a estabelecer as principais diferenças entre estas três concepções heterônomas sobre a música, todas elas de alguma maneira ligadas à questão dos sentimentos despertados ou provocados pela música. A partir destas definições mostraremos como e porque o trabalho de Daniélou estaria mais relacionado à teoria do ethos grego do que às outras formulações.

\subsection{Música Especulativa x Especulação Musical}

A música era, portanto, justamente considerada pelos antigos como a chave para todas as ciências e artes - a ligação entre metafísica e física através da qual as leis universais e suas múltiplas aplicações poderiam ser entendidas ${ }^{155}$ (DANIÉLOU, 1995, p. 1)

Repetimos aqui como epígrafe um trecho da citação utilizada na página 102, do capítulo 3. Como? da Parte 1 acima, para reforçar a ideia de Daniélou sobre a música como

\footnotetext{
${ }^{155}$ Music was therefore justly considered by the ancients as the key to all sciences and arts - the link between metaphysics and physics through which the universal laws and their multiple applications could be understood.
} 
algo que une física e metafísica, que nos daria a chave do entendimento para o que ele chama de leis universais, e de como aplicá-las nas artes.

Entendemos que tal pensamento é similar àquele que no ocidente é chamado de Música Especulativa. No entanto, vemos que este termo muitas vezes é usado como sinônimo da expressão Especulação Musical. Iniciaremos, portanto, fazendo uma distinção que nos permitirá compreender quais seriam as diferenças entre tais expressões, entendidas como duas acepções diferentes de atividades musicais.

As palavras especulativa e especulação são derivadas da atividade proposta pelo verbo especular. Este tem como origem o verbo latino speculare, que significa estudar, observar atentamente.

Vemos então a proximidade existente entre a especulação e a teoria, que significa contemplação. Junte-se a isso a afirmação de Gadamer [cf. p. 101 acima] de que a filosofia era o antigo nome da teoria (GADAMER, 2001, p. 23 et seq.) e temos então o caráter filosófico da atividade especuladora, seja como Música Especulativa ou Especulação Musical.

Por sua vez, a palavra latina speculum significa espelho. A atividade da especulação, portanto, além de caracterizar a observação, o estudo e a contemplação, remete-se também à concepção do estudo ou do pensamento como espelho da realidade, como possibilidade de encontrar no método de estudo e na atividade do pensamento, um reflexo - não por acaso a palavra reflexão cabe como atividade ligada ao efeito causado por espelhos -, uma imagem da realidade. A diferença entre as atividades, como veremos, está no objeto refletido, no caso da Música Especulativa um modelo do Universo, e no caso da Especulação Musical a própria música em sua materialidade.

Tomamos como referência para a Música Especulativa a divisão tripartite de Boécio (480-525/26) descrita em sua obra De Institutione Musica: Musica Mundana, Musica Humana e Musica Instrumentalis (Cf. BOETHIUS, 1989). A Musica Instrumentalis, das três, é a única audível, feita pelo homem através de seus instrumentos ou de sua voz, a Musica Humana trata das relações entre corpo e alma, das relações entre paixões, temperamentos e o físico no ser humano, um reflexo microcósmico do macrocosmo representado pela Musica Mundana, a música do cosmos, dos planetas, dos mundos, enfim, a representação musical do Universo, objeto de estudo do verdadeiro músico, inaudível assim como a harmonia das esferas de Pitágoras.

É de Pitágoras a herança mais visível da Música Especulativa, principalmente sua influência no pensamento platônico. Encontramos exemplos de representações musicais no Timeu e também n'A República de Platão quando, no livro IX, Sócrates fala a Glauco: 
E se, inversamente, se quiser dizer até que ponto o rei dista dos tiranos quanto à autenticidade do prazer, descobrir-se-á, depois de efectuar a multiplicação, que o rei é setecentas e vinte e nove vezes mais feliz e que o tirano é o mais infeliz na mesma proporção. (PLATÃO, 2001, 587d-e)

Considerando que a relação intervalar de quinta justa - para ser mais exato de $12^{\mathrm{a}}$ justa - é representada dentro da série harmônica pelo parcial 3, podemos obter um ciclo de quintas multiplicando sucessivamente por 3 este parcial. Assim fazendo chegamos ao número 729: $3 \times 3=9 ; 9 \times 3=27 ; 27 \times 3=81 ; 81 \times 3=243 ; 243 \times 3=729$. Se substituirmos os números por notas, começando com o número 1 = Dó, temos o seguinte ciclo: 1 = Dó; $3=$ Sol; $9=$ Ré; 27 = Lá; 81 = Mi; 243 = Si e finalmente 729 = Fáł. Vemos então que a relação entre o rei e o tirano é uma relação intervalar de "dissonância máxima (o trítono) da verdadeira vida aprazível, número que mede o quanto o tirano é menos feliz que o rei de si mesmo, o filósofo" (RIZEK, 2003, p. 102), “é o ponto mais distante que pode haver da fundamental, pois distancia-se igualmente desta e de sua projeção oitava acima" (RIZEK, 2003, p. 101). Trata-se do diabolus in musica, intervalo durante muito tempo condenado na prática musical eclesiástica.

A Música como disciplina - junto com a Aritmética, a Geometria e a Astrologia, que hoje chamamos de Astronomia - fazia parte do Quadrivium. Esta atividade era considerada uma ciência, assim como as outras disciplinas do Quadrivium. Ao compararmos com as disciplinas do Trivium - a Retórica, a Gramática e a Dialética -, notamos que se trata de uma oposição que "pode ser reduzida a homem e natureza, mais quantitativos propriamente à linguagem e matemática, [...] a 'mãe' da célebre divisão entre as ciências humanas e as exatas" (RIZEK, 2003, p. 35). Desta forma, a música estaria no ramo das ciências exatas.

Porém, cabe aqui destacar o que nos aponta Burckhardt:

Enquanto a ciência empírica moderna considera, antes de tudo, o aspecto quantitativo das coisas, isolando-o, na medida do possível, de suas conotações qualitativas, a ciência tradicional contempla as qualidades independentemente dos encadeamentos quantitativos. O mundo é como um tecido, feito de uma urdidura e uma trama. As linhas da trama, normalmente as horizontais, simbolizam aqui a matéria, ou, de modo mais imediato, as relações causais racionalmente controláveis e quantitativamente definidas; as linhas verticais correspondem às formae, ou seja, às essências qualitativas das coisas. A ciência e a arte da era moderna evoluem no plano horizontal da trama 'material'; a ciência e a arte da Idade Média, ao contrário, referem-se ao plano vertical, à urdidura transcendente. (BURCKHARDT, 2004, p. 97 itálicos e aspas do autor) 
A ideia de música como ciência pode ser notada desde a obra De Musica de Santo Agostinho, em que define que "a música é a ciência do bem medir"156 (apud TOMÁS, 2005, p. 34). Christensen (2004, p. 5n) afirma que "enquanto os primeiros escritores medievais iriam referir-se à scientia da música em relação ao seu estudo filosófico, os escritores do fim

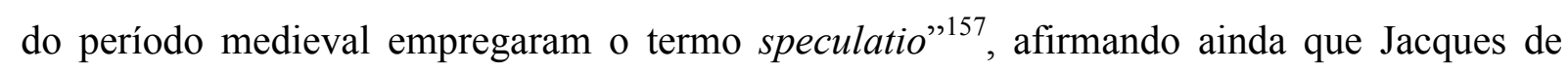
Liége notou que "já havia uma tradução latina perfeitamente boa para a palavra grega theoria: speculum." 158 Vemos aqui não só o termo ciência mas também as palavras speculum e speculatio, que se ligam à nossa discussão sobre a especulação.

Esta tradição do estudo musical no Ocidente Latino "cresceu basicamente a partir da

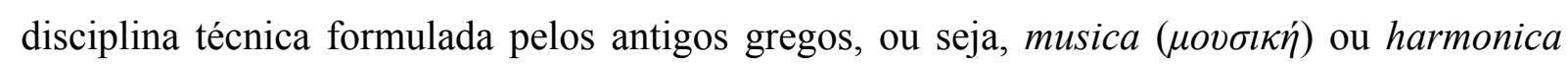

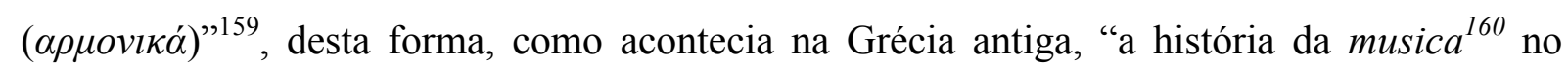
início da Idade Média não pode ser separada da história da educação, da filosofia e da aprendizagem em geral" ${ }^{\prime 61}$ (BOWER, 2004, p. 136).

Embora esta tradição científica da música valorizasse principalmente seu aspecto inaudível, com a Musica Mundana e a Musica Humana boecianas, havia por sua vez a ideia de que a Musica Instrumentalis, ou seja, a música propriamente audível, pudesse representar e dar a conhecer de forma material, por meio do som, esta harmonia inaudível existente nas músicas mundana e humana.

Vemos que esta ideia possui raízes pitagóricas e neoplatônicas, que influenciaram não apenas a filosofia de Boécio, mas toda a sua concepção musical. Como aponta Penelope Gouk, "esta tradição especulativa assume que a música audível é uma expressão tangível dos princípios subjacentes que governam as relações harmônicas entre elementos de todas as estruturas significantes no cosmos" ${ }^{\prime 162}$ (GOUK, 2004, p. 224 grifo nosso). Mais uma vez a expressão especulativa aqui para indicar o tipo de atividade musical do período medieval, a música como ciência, reflexão e especulação, voltada para o conhecimento do Universo.

Por tais características, faz sentido a afirmação de Godwin quando diz que a "música existe para dar aos seres humanos conhecimento sobre o universo, de um tipo inacessível

\footnotetext{
${ }^{156}$ Musica est scientia bene modulandi (AUGUSTINI, s.d., p. 1083)

${ }^{157}$ whereas earlier medieval writers would refer to the scientia of music with regard to its philosophical study, later medieval writers employed the term speculatio

${ }^{158}$ there was already a perfectly good Latin translation for the Greek word theoria: speculum.

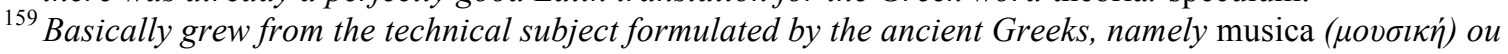
harmonica ( $\alpha \rho \mu$ ovıќ́)

${ }^{160}$ Trata-se aqui do vocábulo latino musica daí o itálico e a ausência de acentuação

${ }^{161}$ the history of musica in the early Middle Ages cannot be separated from the history of education, of philosophy, and of learning in general.

162 this speculative tradition assumed that audible music is a tangible expression of the underlying principles which govern the harmonious relations between the elements of all significant structures in the cosmos.
} 
através de outros canais"163, e que ao estudar esta disciplina, "o músico especulativo descobre princípios universais tão seguramente quanto o matemático ou o filósofo"164 (GODWIN, 1992, p. 271). Tal conhecimento é possível a partir do que Godwin define como Doutrina das Correspondências, em que se pode relacionar, entre diversas possibilidades, ocorrências simbólicas como o número de dias da semana, dos meses e do ano, com a formação de escalas musicais ou mesmo da série harmônica, assim como vimos acima a relação entre o rei e o tirano n'A República de Platão. Veremos com mais atenção estas relações no subcapítulo 2.1.

Simbolismo: correspondências, do capítulo 2. Teoria Musical adiante.

Podemos ter uma noção da Música Especulativa ao tomarmos como referência uma das mais importantes obras de Johannes Kepler (1571-1630), Harmonices Mundi (A Harmonia do Mundo), publicada em 1619.

Nela Kepler elabora suas três leis planetárias do ponto de vista do Sol, descrevendo o movimento dos planetas ao redor deste segundo a velocidade angular de suas órbitas não circulares, no Livro V. Para chegar a estas conclusões Kepler elabora seus cálculos segundo harmonias musicais, descrevendo as órbitas de cada planeta como representando um intervalo musical entre a distância mais próxima e a mais distante do Sol (GODWIN, 1995, p. 133), de modo que ao se movimentar produziria uma melodia, sendo a combinação das melodias de todos os planetas aquilo que se poderia chamar de Harmonia das Esferas, presente desde Pitágoras. Mas, como dito acima,

Kepler inovou ao ouvir a Música das Esferas não do ponto de vista da Terra, como todos os seus predecessores, mas do Sol. Daí em diante já não é mais uma harmonia feita para o benefício do nosso próprio planeta, mas a música que o cosmos canta para seu senhor e centro, o Logos Solar. ${ }^{165}$ (GODWIN, 1995, p. 133)

Segundo Penelope Gouk "nestes aparentes movimentos encontram-se o sistema das notas da escala musical, bem como os modos maiores e menores"166 (2004, p. 233).

Embora sua data de publicação seja de uma época em que a música já havia praticamente migrado do Quadrivium para o Trivium, visto que é justamente na retórica que o fazer musical vai se apoiar no período Barroco, Kepler baseia-se numa tradição anterior,

\footnotetext{
${ }^{163}$ Music exists in order to give human beings knowledge about the universe, of a kind that is inaccessible through other channels.

${ }^{164}$ The speculative musician discovers universal principles as surely as the mathematician or the philosopher

${ }^{165}$ Kepler had broken new ground in listening to the Music of the Spheres not from the point of view of Earth, like all his predecessors, but from the Sun. Henceforth it is no longer a harmony made for the benefit of our own planet, but the song which the cosmos sings to its lord and centre, the Solar Logos.

${ }^{166}$ In these apparent motions are found the system of the notes of the musical scale, as well as the major and minor modes
} 
naquela que denominamos Música Especulativa.

Tal opção de Kepler está afinada com a visão luterana da música, pois, como afirma Dietrich Bartel em seu livro Musica Poetica (1998), "ao invés de ver a música como uma inovação fundamentalmente humana, Lutero acreditava na música como sendo um presente essencialmente divino para a humanidade"167 (p. 3), de maneira que "esta origem divina da música estabeleceu Deus como o autor e fonte do fenômeno natural do som, incluindo o mundo dos sons musicais"168 (p. 3). Desta forma, na Alemanha,

a teoria musical especulativa baseada nas proporções numéricas dos intervalos musicais não se tornou uma conjectura irrelevante, como o foi para a concepção mais humanisticamente inclinada, mas era pertinente para o entendimento do poder divinamente ordenado da música ${ }^{169}$ (BARTEL, 1998, p. 3)

No entanto, vemos outro grande pensador, desta vez um não germânico, adotar aquilo que estamos delimitando como Música Especulativa. Isaac Newton (1643-1727) apoia-se no estudo musical para desenvolver sua teoria das cores no seu tratado Opticks de 1704, pois se o continuum sonoro divide-se em sete notas para o desenvolvimento musical, em sete cores também deveria dividir-se o continuum luminoso (GOUK, 2004, p. 235 e PIANA, 2001, p. 222).

Joscelyn Godwin, em seu livro Harmonies of heaven and earth, afirma que o inglês Robert Fludd (1574-1637) - estudioso do Hermetismo, cuja capacidade de mudar de pontos de vista, atitude semelhante à de outros hermetistas e que é também semelhante à teoria cosmológica hindu (cf. subcapítulo 2.4. Música e Metafísica em Alain Daniélou da Parte 1 acima) adotada por Alain Daniélou - "deixa claro que não há uma maneira fixa de olhar para as coisas" ${ }^{\prime 170}$ (GODWIN, 1995, p. 159).

Godwin ainda detalha a importância desta forma de abordagem e de como Fludd procurava relacionar diversas doutrinas e formas de conhecimento com o conhecimento musical:

A aprendizagem profunda e extensa de Fludd possibilitou a ele familiarizar-

\footnotetext{
${ }^{167}$ Rather than viewing music as a primarily human innovation, Luther believed music to be essentially a divine gift to humanity

${ }^{168}$ This divine origin of music established God as the author and source of the natural phenomenon of sound, including the world of tones.

${ }^{169}$ Speculative musical theory based on the numerical proportions of musical intervals did not become irrelevant conjecture, as it did for the more humanistically minded, but rather was germane to understanding music's divinely ordained power.

${ }^{170}$ makes it clear that there is no one fixed way of looking at things
} 
se com uma série de doutrinas distintas, cada uma das quais o seu ecumenismo natural reconheceu como contendo um verdadeiro insight sobre a natureza das coisas. Para citar algumas delas: havia a descrição matemática do Timeu de Platão, o sistema espacial do cosmos Ptolomaico, expandido pela adição das Hierarquias Angélicas, a doutrina hermética de que o homem, o Microcosmo, reflete a estrutura do Macrocosmo; a hierarquia evidente dos estados de consciência, desde o Intelecto conhecedor de Deus descendo até o reino mineral. Finalmente, havia a organização interna da própria Divindade nas três Pessoas da Santíssima Trindade, no Tetragrammatron quádruplo I H V H, ou na dualidade da ação e não ação. Como é que alguém pode juntar tudo isso? É difícil conceber uma aplicação mais poderosa da musica speculativa - da música como espelho da realidade - do que a tentativa de Fludd de unificar todas estas verdades díspares através do símbolo do monocórdio e da sua escala. ${ }^{171}$ (GODWIN, 1995, p. 164 negrito nosso)

Vemos então que, ainda que a Música Especulativa seja identificada principalmente como uma disciplina do Quadrivium e, portanto, ligada ao pensamento medieval, notamos nos exemplos dos pensadores citados acima, Johannes Kepler, Isaac Newton, Philipp Melanchthon e Robert Fludd, que a ideia da música como uma disciplina - ou utilizando um termo moderno assumindo o risco do anacronismo - como um método para o entendimento do universo, durou mais do que pode parecer num primeiro momento, chegando até o período que na História da Música definimos como Barroco ou Pré-Clássico.

No entanto, como bem aponta Joscelyn Godwin (1992, p. 256), para além de uma ciência a música também é uma arte, e começa a ser cada vez mais assim considerada com o advento das Belas Artes e sua progressiva passagem do Quadrivium para o Trivium.

A mudança desta abordagem, da Música Especulativa como um método para o entendimento do universo para a Especulação Musical, se dá após período conhecido como Revolução Científica. Penelope Gouk aponta que este período os "historiadores da ciência observam ocorrer no pensamento ocidental entre o século XVI e o início do século XVIII"172 (GOUK, 2004, p. 223).

Mais especificamente, "entre a publicação de De Revolutionibus de Nicolaus Copernicus em 1543 e de Principia mathematica de Isaac Newton em 1687, uma profunda

\footnotetext{
${ }^{171}$ Fludd's deep and extensive learning had acquainted him with a number of disparate doctrines, each of which his natural ecumenicism recognized as containing a true insight into the nature of things. To name some of them: there was the mathematical description of Plato's Timaeus; the spatial system of the Ptolomaic cosmos, expanded by the addition of the Angelic Hierarchies; the Hermetic doctrine that Man the Microcosm reflects the structure of that Macrocosm; the evident hierarchy of states of consciousness, from the Godknowing Intelect down to the mineral realm. Finally, there was the inner organization of the Godhead itself into the three Persons of the Holy Trinity, into the fourfold Tetragrammatron I H V H, or into the duality of action and non action. How is one to bring all this together? It is difficult to conceive of a more powerful application of musica speculativa - of music as mirror of reality - than Fludd's attempt to unify all these disparate truths through the symbol of the monochord and its scale.

${ }^{172}$ historians of science see taking place in Western thinking between the sixteenth and early eighteenth centuries
} 
transformação ocorreu no entendimento sobre as leis que regem o universo e o lugar do homem dentro dele" ${ }^{\prime 13}$ (GOUK, 2004, p. 223).

Define-se assim este período porque

depois do aparecimento de Principia, [...] o Newtonianismo rapidamente torna-se o paradigma para o método científico adequado. Nesta obra, Newton conseguiu expandir o domínio simbólico da matemática unificando os princípios matemáticos que subjazem ações mecânicas manifestas e forças atrativas ocultas. ${ }^{174}$ (GOUK, 2004, p. 241-242)

No caso especificamente musical, como afirma Lia Tomás,

o período conhecido por Renascimento Carolíngio (entre os séculos IX e XI) é marcado por um gradativo afastamento dos princípios teológicos que regiam a estética musical e um encaminhamento para questões de ordem mais prática, tais como a normatização de uma teoria musical, problemas relacionados à composição e à interpretação (TOMÁS, 2005, p. 43)

É dessa época o início da polifonia e os problemas de notação e mensuração rítmica da música começam a se fazer mais presentes. Uma das figuras mais importantes deste período é Guido d'Arezzo, que, embora adotasse a visão boeciana da música, foi um dos maiores responsáveis pelo desenvolvimento da teoria musical ligada às questões pedagógicas, de forma que "os tratados de Guido d'Arezzo, em razão do interesse crescente dos teóricos pelos problemas didáticos, transformam-se, nos séculos seguintes, em um ponto de referência obrigatório" 175 (FUBINI, 2001b, p. 109).

No entanto, apesar deste progressivo foco do estudo musical em suas atividades práticas, a visão boeciana da música continua presente com suas especulações metafísicas, "é notável a simultaneidade dos eventos, ou seja, o declínio da soberania do pensamento cristão como justificador da teoria e prática musical e a ascensão de questionamentos voltados para a realidade musical concreta" (TOMÁS, 2005, p. 43).

Os "questionamentos voltados para a realidade musical concreta" passam a ser preponderantes a partir da Revolução Científica, pois a música deixara de ser uma ciência para cada vez mais ser entendida como arte.

\footnotetext{
${ }^{173}$ Between the publication of Nicolaus Copernicus's De revolutionibus in 1543 and Isaac Newton's Principia mathematica in 1687, a profound transformation took place in understanding about the laws governing the universe and man's place within it.

${ }^{174}$ after the Principia appeared, [...] Newtonianism rapidly became the dominant paradigm for proper scientific method. In this work, Newton succeeded in expanding the symbolic realm of mathematics by unifying the mathematical principles that underlay manifest mechanical actions and occult attractive forces.

${ }^{175}$ Los tratados de Guido de Arezzo, en razón al interés creciente de los teóricos por problemas didácticos, se transforman, en los siglos sucesivos en un punto de referencia obligado.
} 
Isto se dá, em primeiro lugar porque a "música sofreu uma perda de status porque não funcionava mais como um importante modelo teórico" "176 (GOUK, 2004, p. 241); em segundo lugar porque há um "contraste entre o status marginal da filosofia experimental por volta de 1600 e sua bem sucedida institucionalização por volta de 1700""177 (GOUK, 2004, p. 242); e em terceiro lugar a música tem um

crescente reconhecimento como uma das belas artes junto com a pintura e a escultura. Decisivamente, não foram apenas filósofos e cientistas que viram a música como estando fora de seu domínio. Compositores e teóricos musicais celebraram o poder que a música exercia sobre a imaginação, e especialmente sua capacidade para representar e mover as emoções. Ao invés de enfatizar o controle técnico e matemático de suas habilidades composicionais, os praticantes preferem agora ver a si mesmos como manipuladores de paixões divinamente inspirados. Dentro desta estética havia muito pouco a ser ganho na ligação da música com as ciências naturais. ${ }^{178}$ (GOUK, 2004, p. 243)

A este respeito, Mônica Lucas afirma que

autores setecentistas referem-se à música como 'imitação sonora' pelo viés do trivium: a voz (cantada), a melodia e o ritmo musicais são entendidos como veículos para mover o público imitando as paixões humanas. [...] Nesse sentido, a música relaciona-se ao gênero de artes ligadas à palavra, o trivium, que, segundo Boécio, reúne a dialética, a gramática e a retórica. A ideia de música como discurso de paixões ganhou impulso com o aparecimento da Poética de Aristóteles e é uma das principais características da música barroca. (LUCAS, 2007, p. 225)

Ela ainda completa: “embora a música seja definida nas poéticas musicais dos séculos XVII e XVIII como ciência e como arte, os escritos técnicos enfatizam a concepção discursiva, concebendo-a sob o viés retórico" (LUCAS, 2007, p. 225).

Ou seja, a música passa de ciência para arte, e seus aspectos científicos e especulativos vão aos poucos migrando para outras disciplinas como a acústica musical, a psicologia da música ou a cognição musical. Outras correntes apoiam-se em disciplinas distintas para a pesquisa científica da música, como a utilização da Matemática, Semiótica ou da Teoria da

\footnotetext{
${ }_{176}$ music suffered a loss of status because it no longer functioned as an important intellectual model

${ }^{177}$ Contrast between the marginal status of experimental philosophy around 1600 and its successful institutionalization by the 1700 s

${ }^{178}$ Growing recognition as one of the fine arts along with painting and sculpture. Crucially, it was not just philosophers and scientists who saw music as lying outside their domain. Composers and music theorists celebrated the power music exercised over the imagination, and especially its capacity to represent and move the emotions. Instead of emphasizing their mathematical and technical mastery of compositional skills, practitioners now preferred to see themselves as divinely inspired manipulators of the passions. Within this aesthetic there was little to be gained in linking music with the natural sciences.
} 
Gestalt na Análise Musical e na composição; do método antropológico ou mesmo sociológico para o desenvolvimento da Etnomusicologia; ou da Psicologia para o estudo da interpretação musical.

Embora possamos entender a Musicologia num sentido lato como todo e qualquer estudo sobre a música, como aquilo que poderia ser definido como a ciência da música, vemos que há uma diferença entre a Música Especulativa, a música como espelho do Universo ou da realidade, possibilitando a criação de modelos teóricos para o entendimento deste Universo e a Especulação Musical, na acepção moderna de ciência como produção de conhecimento, tendo a música como objeto de estudo.

Com relação ao trabalho musical de Alain Daniélou, consideramos que ele está inserido nas duas possibilidades de entendimento do estudo musical: tanto na Especulação Musical, entendendo esta como compartilhando da acepção moderna de ciência como produção de conhecimento, tomando a música como objeto de estudo, além de se utilizar de outras disciplinas que contribuiriam para o entendimento desta, quanto na Música Especulativa, pois ao tomar como ponto de referência a música indiana, carrega consigo os preceitos metafísicos que regem o entendimento desta arte que também é considerada uma ciência pelos hindus, dado que a própria cosmologia e cosmogonia Hindu entende o cosmos como uma vibração sonora, o Nādā Brahma (Som-mundo ou Som-Deus) a partir do qual todo o universo é gerado (BERENDT, 1997, p. 27-31 passim)

Estas abordagens de Daniélou podem ser encontradas especialmente em dois de seus livros sobre música, que ele considera como seus livros mais importantes sobre o assunto [cf. p. 24 acima e DANIÉLOU, 1987, p. 235-236]: Traité de Musicologie Comparée [que na sua versão mais atual se chama Music and the Power of Sound] e Sémantique Musicale.

Podemos classificar seu livro Sémantique Musicale (1993) como um típico trabalho de Especulação Musical, pois nele Daniélou se concentra no estudo dos possíveis efeitos psicofisiológicos produzidos pela música. Ou seja, seu objeto de estudo é a música em sua materialidade, a relação entre as frequências enquanto fenômenos analisáveis pelo ouvido humano, tendo como hipótese a ideia de que estas relações entre as frequências, o que chamamos musicalmente de intervalos, produziriam determinadas consequências em quem as ouve.

Para tal empreitada, como dito acima, Daniélou baseia-se no texto Elementary thinking and the classification of Behavior de Henry S. Marck; nos livros Cybernetics de Wiener e Vues nouvelles sur le monde des sons de Fritz Winckel e na ideia de que os sons são percebidos pelo tímpano como resultantes de pressões e depressões, uma vez que o mesmo é 
uma membrana que funcionaria de forma análoga a de uma pele de tambor.

Desta forma o cérebro interpretaria os intervalos musicais, que são as relações entre as frequências, como combinações resultantes destas pressões e depressões no tímpano e as interpretaria como pertencendo a três sistemas numéricos - binário, ternário e quinário, que se associam a três intervalos e suas inversões, respectivamente a oitava justa, a quinta justa e a terça maior justa.

Cada um destes sistemas numéricos possuiria uma característica determinante: o de base 2, que se relaciona com a oitava justa, teria um caráter estático, espacial e cíclico; o de base 3, associado ao intervalo de quinta justa, possuiria um caráter motor e ativo e o de base 5 , que por sua vez se relaciona com a terça maior justa ou natural, teria um caráter emotivo.

Por outro lado, consideramos o livro Music and the Power of Sound (1995) como um trabalho relacionado à disciplina Música Especulativa. Entendemos esta obra desta forma pois nela Daniélou trabalha exclusivamente com a teoria musical.

No entanto cabe aqui um pequeno esclarecimento. Christensen nos mostra que Carl Dahlhaus, em seu texto Grundzüge einer Systematik, distingue três grandes tradições de teoria musical: a especulativa, a prática e a análise musical. A "especulativa" é a "contemplação ontológica dos sistemas sonoros" $" 179$, que incluiria, entre outros estudos, "pesquisas nas áreas da acústica e teoria da afinação nos séculos XVII e XVIII e psicologia sonora nos séculos XIX e XX" "180. A tradição da teoria "prática" é, segundo Dahlhaus,

a "regulação" e "coordenação" destes sistemas acústicos aplicados à prática composicional. Como uma disciplina regulatória, tal "teoria" musical busca extrair da prática regras normativas de sintaxe e modelos de estruturas, e ao mesmo tempo disciplinar tal prática através de restrições pedagógicas. Aqui nós teríamos uma categoria ainda mais expansiva de escritos pedagógicos atravessando os séculos e tocando em praticamente em todos os parâmetros musicais: contraponto, harmonia, ritmo, métrica, melodia, forma, gênero e estilo. ${ }^{181}$ (apud CHRISTENSEN, 2004, p. 13-14)

Ainda segundo Christensen, Dahlhaus acrescenta uma terceira tradição teórica que é a da Análise Musical (2004, p. 13-14).

A teoria com que trabalha Alain Daniélou em Music and the power of sound não

\footnotetext{
${ }^{179}$ ontological contemplation of tone systems

${ }^{180}$ research in the areas of acoustics and tuning theory during the seventeenth and eighteenth centuries and tone psychology in the nineteenth and twentieth centuries

181 the "regulation" and "coordination" of these tone systems applied to compositional practice. As a regulatory discipline, such music "theory" seeks to draw from practice normative rules of syntax and models of structure, while at the same time disciplining that practice through pedagogical strictures. Here we would have an even more expansive category of pedagogical writings crossing the centuries and touching on just about every parameter of music: counterpoint, harmony, rhythm, meter, melody, form, genre, and style.
} 
corresponde a nenhuma destas definidas por Dahlhaus e apontadas por Christensen, embora ela esteja bem próxima da expressão "contemplação ontológica dos sistemas sonoros"182, entendemos que ao buscar um elemento comum entre as músicas clássicas Chinesa, Indiana, Grega antiga e Ocidental, e que este elemento comum é a teoria destas músicas, porém não tanto no sentido gramatical ou regulatório, mas no seu sentido simbólico e metafísico interpretando estas teorias no que podem propiciar de entendimento da realidade ou do conhecimento cosmológico e cosmogônico de cada civilização -, Daniélou exerce uma atividade que está muito próxima daquilo que definimos acima como Música Especulativa, que segundo Godwin seria a música como espelho da realidade.

Ao investigar tais teorias Daniélou afirma que seus sistemas não são diferentes e sim sistemas complementares (DANIÉLOU, 1995, p. 10-11), pois se baseiam no mesmo fenômeno acústico. Por tal motivo, entre outros, é um defensor da afinação natural, condenando o Temperamento Igual que é atualmente o sistema predominante em todo o mundo, mesmo nos países orientais e tanto na música clássica quanto na música popular.

Daniélou considera que o Temperamento Igual fecha as possibilidades de abertura metafísica ao homem. A escala natural não "fecharia" - e por isso desenvolvemos o Temperamento Igual - porque "há uma imperfeição na própria base da existência do mundo, porque se o mundo fosse perfeito ele seria imediatamente reabsorvido na infinita perfeição" "183 (DANIÉLOU, 1995 p. 7). Podemos ter uma noção desta reabsorção quando, num estúdio, sobrepomos as ondas senoidais afinadas nas frequências dos primeiros parciais de uma série harmônica. Elas não soam como um acorde e sim como um som muito próximo ao de um oboé. Ou mesmo se recordarmos os procedimentos da música eletrônica baseados no serialismo integral, em que ao se tentar serializar o timbre, ou se perde a noção de série, e portanto a estrutura que organiza a música fica oculta, pois o timbre é um amálgama sonoro em que não se identifica a série, ou soa como um acorde, que por sua vez não é um timbre.

Com relação à coma pitagórica - que é a diferença entre a nota Si\# obtida pela superposição de 12 quintas e a nota Dó obtida pela superposição de sete oitavas - que pode ser encontrada tanto na Escala Pitagórica quanto na Escala Justa e mesmo na série harmônica, Daniélou afirma, remetendo-se ainda a essa "imperfeição na própria base de existência do mundo":

\footnotetext{
${ }^{182} \mathrm{Cf}$. Acima na Parte 1 o subcapítulo 2.2 Música e o poder do som (Tratado de Musicologia Comparada).

${ }^{183}$ there is an imperfection at the very basis of the world's existence, because if the world were perfect it would be reabsorbed into the infinite perfection.
} 
Do mesmo modo o desenvolvimento de doze quintas, ao invés de nos trazer de volta de forma precisa à oitava, deixa uma diferença - a coma - com a qual nós temos que negociar. [...] Esta coma, que o mundo moderno se esforça tanto por ignorar, representa, para aqueles que podem entender, a diferença essencial entre o que é finito e o que é infinito. As quintas formam uma espiral cujos sons, enrolados em torno de si, nunca podem se encontrar. Para nós, esta espiral sem limites pode ser a junta [articulação] na estrutura do mundo, o portão estreito que vai nos permitir escapar da aparência de um universo fechado, para viajar em outros mundos e explorar seus segredos. ${ }^{184}$ (DANIÉLOU, 1995 p. 7-8)

Para unificar os sistemas teóricos estudados, Daniélou cria uma escala que batizou de Escala Universal dos Sons, dividindo a oitava em 53 intervalos, utilizando apenas relações intervalares que empreguem os fatores 2, 3 e 5, o que pode ser definido como uma elaboração escalar utilizando a série harmônica com limite 5, ou seja, utilizar as notas geradas por uma série harmônica que sejam múltiplas dos parciais 2,3 e 5 .

Esta escala, segundo Daniélou, funcionaria como uma espécie de "régua" que poderia ao mesmo tempo servir para explicar as notas utilizadas nas escalas empregadas nas músicas clássicas das tradições por ele investigadas e, ao mesmo tempo, ser utilizada para experimentos que pudessem testar os efeitos produzidos por tais intervalos nas emoções dos seres humanos, tal como proposto em Sémantique Musicale.

Relembremos aqui a afirmação de Piana sobre a escala de Daniélou [cf. p. 98 acima]:

quando, por sua vez, a relação numérica vem atribuída à vibração de um corpo elástico e ocorre assim o reencontro do número com o elemento físico, as considerações metafísicas vão para segundo plano, a numerologia interessa muito menos do que interessa uma possível análise da constituição interna do som como evento da natureza. ${ }^{185}$ (PIANA, 2003 p. 29)

As intenções de Daniélou ao criar esta escala, além das citadas acima, inclui também a utilização desta como matéria-prima para a criação musical. Esta escala, em que as relações entre as frequências são mais importantes do que as notas em si, se estenderia também pelos aspectos temporais e formais, aproximando-se desta maneira da Unidade do Tempo Musical

${ }^{184}$ In the same way the development of twelve fifths, instead of bringing us back precisely to the octave, leaves a difference-the comma-with which we shall have to negotiate. [...] This comma, which the modern world tries so hard to ignore, represents, for those who can understand it, the essential difference between what is finite and what is infinite. The fifths form a spiral whose sounds, coiled around themselves, can never meet. For us, this limitless spiral can be the joint in the structure of the world, the narrow gate that will allow us to escape from the appearance of a closed universe, to travel in other worlds and explore their secrets.

${ }^{185}$ Quando invece il rapporto numerico viene attribuito alle vibrazioni di un corpo elastico ed avviene cosi la ricongiunzione del numero con l'elemento fisico, le considerazioni metafisiche regrediscono sullo sfondo, la numerologia interessa assai meno di quanto interessi una possibile analisi della costituzione interna del suono come evento della natura. 
proposta por Karlheinz Stockhausen (1996). Além disso podemos aproximá-la daquilo que Xenakis define como uma estrutura fora-do-tempo (1971, p. 183).

Desta forma, Daniélou trabalha tanto dentro daquilo que definimos como Música Especulativa, ao utilizar a Teoria Musical como um aspecto comparativo não só entre as culturas musicais, mas também em seus aspectos cosmológicos e cosmogônicos, quanto da acepção de Especulação Musical, utilizando a música como objeto de estudo e sua escala como uma possibilidade criativa.

Por isso sua escala não é apenas uma ferramenta para a interpretação e estudo da harmonia do cosmo ou da realidade metafísica, como eram utilizados os monocórdios na Idade Média (cf. HERLINGER, 2004), mas também matéria-prima para fazer surgir uma nova música, que leve em consideração também os efeitos psicofisiológicos proporcionado por suas relações intervalares, uma vez que ela possibilita, como aponta Piana acima, um "reencontro do número com o elemento físico". Além disso ela possibilitaria novos estudos em outras áreas. Daniélou afirma: "minha pesquisa sobre a fenomenologia e a teoria física da música, bem como sua aplicação na musicologia comparada, tem sido de considerável interesse a músicos contemporâneos, musicólogos, etnólogos e mesmo psicólogos e médicos"186 (DANIÉLOU, 2003b, p. 201).

Desta forma seus estudos não são anacrônicos, não se trata de uma apologia ao pensamento medieval fora de época, eles possuem uma ligação com as necessidades atuais, possibilitam uma releitura e atualização destes pensamentos para o nosso tempo.

\subsection{Música sagrada $x$ sacralização da música}

Como trepávamos pelo carreiro íngreme que serpenteava em torno do monte, vi a abadia. Não me espantaram as muralhas que a cingiam por todos os lados, semelhantes a outras que vi em todo o mundo cristão, mas a mole daquilo que depois soube que era o Edifício. Esta era uma construção octogonal que à distância parecia um tetrágono (figura perfeitíssima que exprime a solidez e a inexpugnabilidade da Cidade de Deus), cujos lados meridionais se erguiam no planalto da abadia, enquanto os setentrionais pareciam crescer das próprias faldas do monte, nas quads se encaixavam a pique. Digo que em certos pontos, de baixo, parecia que a rocha se prolongava para o céu, sem solução de tons nem de matéria, e se tornava a

\footnotetext{
${ }^{186}$ My research on the phenomenology and physical theory of music, as well as their application in comparative musicology, has been of considerable interest to contemporary musicians, musicologists, ethnologists and even psychologists and medical men.
} 
certa altura um maciço torreão (obra de gigantes que tivessem grande familiaridade com a terra e com o céu). Três ordens de janelas diziam o ritmo ternário da sua elevação, de modo que aquilo que era fisicamente quadrado sobre a terra era espiritualmente triangular no céu. Ao aproximarmo-nos mais, percebia-se que a forma quadrangular gerava, em cada um dos seus ângulos, um torreão heptagonal, cujos cinco lados se adiantavam para o exterior - quatro portanto dos oito lados do octógono maior, gerando quatro heptágonos menores, que do exterior se manifestavam como pentágonos. E não há quem não veja a admirável concórdia de tantos números santos, revelando cada um, um sutilíssimo sentido espiritual. Oito o número da perfeição de todo o tetrágono, quatro o número dos evangelhos, cinco o número das zonas do mundo, sete o número dos dons do Espírito Santo. Pela mole e pela forma, o Edifício apareceu-me como mais tarde havia de ver no Sul da península italiana Castel Urbino ou Castel dal Monte, mas pela sua posição inacessível era mais terrível do que aqueles e capaz de produzir temor no viajante que dele se aproximasse pouco a pouco. E por sorte que, sendo uma límpida manhã de inverno, a construção não me apareceu tal como se vê nos dias de tempestade.

Monge Adso em $O$ nome da Rosa

(ECO, 1983, p. 35-36)

Na realidade, a ciência dos símbolos é a mais exata das ciências, a ciência por excelência, a ciência da interpretação das ciências. (BENEITO, 2007, p. 17)

A geometria é uma música imóvel (GOETHE apud LAWLOR, 1996. p. 80)

Assim como no subcapítulo anterior trabalhamos com duas acepções especulativas relacionadas ao estudo musical, trabalharemos aqui com duas interpretações do que podemos considerar como o elemento sagrado ligado à música.

Estas duas interpretações que descrevemos aqui como Música Sagrada e Sacralização da Música, carregam em si termos similares - o sagrado - que, no entanto, referem-se a duas maneiras praticamente antagônicas de se definir a música. Enquanto a primeira refere-se à música como uma espécie de veículo para elementos extramusicais, portanto uma acepção heterônoma da música, a segunda diz respeito à música entendida como autônoma, com valor apenas em si mesma.

É preciso distinguir estas duas formas de entender o sagrado ligado à música, pois não se trata aqui de utilizar o termo sagrado ou sacro como sendo simplesmente a música ligada a algum tipo de ritual ou possuindo algum tipo de assunto religioso. Nem a música sagrada, nem a sacralização da música possuem esta conotação.

Com relação à Música Sagrada, por este motivo, optamos por não utilizar o termo Música Sacra, pois entendemos que esta forma de denominação já carrega historicamente, no ocidente ao menos, o entendimento de uma música ou que pertença a algum tipo de ritual como por exemplo as Missas compostas no decorrer da história da música - ou que possua 
tema religioso, como eventuais hinos devotados a diversos santos ou mesmo orações musicadas, como o Pai Nosso ou a Ave Maria.

Ao utilizar o termo Música Sagrada nos remetemos à obra de Titus Burckhardt, $A$ arte sagrada no oriente e no ocidente: princípios e métodos. É a partir dela que iremos explicar o que entendemos por música sagrada, e consequentemente porque entendemos que a forma como Alain Daniélou entende a música, principalmente a partir da música indiana, se aproxima desta arte definida por Burckhardt.

Retomando o que já descrevemos acima [p. 90], Titus Burckhardt, em seu livro $A$ arte sagrada no oriente e no ocidente: princípios e métodos, faz uma distinção entre o que chama de arte sagrada, uma arte na qual "não basta que seus temas derivem de uma verdade espiritual. É necessário, também que sua linguagem formal testemunhe e manifeste essa origem" (BURCKHARDT, 2004, p. 17), e o que denomina de maneira geral como arte religiosa, por exemplo, a arte sacra do Renascimento e do Barroco, "que absolutamente não se distingue, enquanto estilo, da arte fundamentalmente profana da mesma época" (BURCKHARDT, 2004, p. 17). De forma que "há, pois, obras de arte essencialmente profanas de temas sagrados, mas não pode haver obra sagrada de formas profanas, já que existe uma analogia rigorosa entre a forma e o espírito" (BURCKHARDT, 2004, p. 18).

Para entendermos melhor a ideia de "analogia rigorosa entre a forma e o espírito" devemos abordar a acepção tradicional de símbolo, uma vez que entendemos que o símbolo é uma das possíveis maneiras de estabelecer tal analogia.

Com relação à palavra símbolo, Sylvia Leite nos mostra que a transformação semântica que esta sofreu ao longo dos séculos tem como consequência uma espécie de perda do elo entre significante e significado, principalmente "se compararmos o seu sentido etimológico, de união, ao sentido usual que lhe é atribuído hoje, e que está mais próximo de convenção arbitrária, isto é, de representação dissociada do objeto que representa" (LEITE, 2009, p. 13).

Para tal afirmação utiliza como base Pierre Chantraine e seu Dictionnaire étymologique de la langue grecque. Histoire des mots e Anatole Bailly e seu Dictionnaire Grec-Français definindo assim a palavra símbolo:

O substantivo grego sỳmbolon, do qual deriva, é composto por um radical que vem do verbo grego "bāllo", e significa lançar, combinado com o prefixo "sỳn" - equivalente ao prefixo latino "com" - que expressa a idéia de reunião, junção. Assim, a palavra símbolo pode ser compreendida, com base no ponto de vista etimológico, como referente a uma realidade que está 
unida ao seu veículo de representação. ${ }^{187}$ (apud LEITE, 2009, p. 13 aspas e itálicos da autora)

A autora não pretende, como também não pretendemos aqui, "questionar a utilidade ou a legitimidade de tais representações, e sim propor uma distinção entre um veículo que traz consigo a realidade representada e outro cujo vínculo entre os dois termos se dá apenas por uma convenção" (LEITE, 2009, p. 14).

E ainda:

Se, para efeito de compreensão, tomarmos emprestada a terminologia da Lingüística, poderemos dizer que em seu sentido etimológico, a palavra símbolo é um significante que carrega consigo a realidade do significado ao contrário do sentido atual pelo qual o significante cumpre apenas o papel de representar o significado por meio de uma determinação arbitrária. (LEITE, 2009, p. 13)

Porém, para que se possa entender de maneira mais efetiva tal ideia de símbolo, deixemos o próprio Burckhardt falar:

Toda arte sagrada baseia-se, pois, em uma ciência das formas, ou, em outras palavras, no simbolismo inerente às formas. É preciso que se tenha em mente que um símbolo não é apenas um sinal estabelecido convencionalmente, mas manifesta seu arquétipo em virtude de uma lei ontológica definida; como Coomaraswamy observou, um símbolo é, de certo modo, aquilo que exprime. Por esta razão, o simbolismo tradicional nunca é desprovido de beleza: de acordo com a visão espiritual do mundo, a beleza de algo não é senão a transparência de seus envoltórios ou véus existenciais; em uma arte autêntica, uma obra é bela porque é verdadeira. (BURCKHARDT, 2004, p. 19 destaque do autor)

\section{Daniélou também considera que}

a maior parte dos elementos de nosso sistema musical são relacionados a uma teoria cosmológica milenar e a um simbolismo muito antigo, como são também as raízes e formas de linguagem, instrumento de nosso pensamento, assim como muitas das nossas formas de medir o tempo e o espaço. ${ }^{188}$ (DANIÉLOU, 2004, p. 15 destaque nosso)

\footnotetext{
${ }^{187}$ Consideramos interessante acrescentar aqui também a nota de rodapé da autora: "O antônimo de symbolon é diábolon, palavra formada pela combinação do verbo "ballo", o mesmo que está presente na palavra symbolon, com o prefixo "diâ", que significa "através de, no meio de", expressa a idéia de separação ou divisão." (apud LEITE, 2009, p. 13 nota $n^{\circ} 9$ aspas e itálicos da autora)

${ }^{188}$ La plupart des éléments de notre système et de notre vocabulaire musical sont liés à une théorie cosmologique millénaire et à un très ancien symbolisme comme le sont aussi les racines et las formes du langage, instrument de notre pensée, ainsi que beaucoup de nos manières de mesurer le temps et l'espace.
} 
Vemos aqui a convergência de pensamento a respeito da relação que se pode estabelecer entre símbolo, arte - mais especificamente a música - e uma teoria cosmológica milenar que, além de estar presente em outras áreas de nossas atividades, possibilita esta conexão entre cosmos, leis universais e o entendimento humano sobre tais assuntos.

Para Burckhardt, a forma possibilita a manifestação da verdade como beleza porque,

por sua essência qualitativa, a forma ocupa uma posição, na ordem sensível, análoga à da verdade, na ordem intelectual; este é o significado da noção grega de eîdos. Assim como uma forma mental, como um dogma ou uma doutrina, pode ser o reflexo adequado, ainda que limitado, de uma Verdade divina, assim também uma forma sensível pode representar e expressar uma verdade ou realidade que transcende tanto o plano das formas sensíveis quanto o plano do pensamento. (BURCKHARDT, 2004, p. 18)

Burckhardt também afirma que "nenhuma categoria de arte pode ser definida como sagrada a menos que também sua forma reflita a visão espiritual característica da religião da qual provém" (BURCKHARDT, 2004, p. 18).

Por sua vez, Seyyed Hossein Nasr - em seu prefácio à edição francesa d' $A$ arte sagrada no oriente e no ocidente de Titus Burckhardt - refere-se à arte sagrada como "uma arte que, por ser sagrada, tem suas raízes no eterno, já que o sagrado não é senão a manifestação do Eterno no temporal, ou do Centro no contorno da roda da existência" (NASR, 2004, p. 14).

Ao refletir a visão espiritual da religião, não necessariamente deverá carregar explicitamente traços de sua prática exterior, por isso, como afirma Burckhardt, podem existir "obras de arte essencialmente profanas de temas sagrados" (2004, p. 18), basta que formalmente tais obras não reflitam "a visão espiritual característica da religião da qual provém" (2004, p. 18), ainda que possuam temas religiosos, ou seja, a arte sagrada tem, deste modo, uma relação muito mais efetiva com o sentido esotérico da religião do que com sua manifestação ou expressão exotérica. Além disso, como afirma Schuon, "todo esoterismo apresenta laivos de heresia, do ponto de vista do exoterismo correspondente" (SCHUON, 1985, p. 1). Porém observa que

as teses religiosas por certo não constituem erros, mas são fragmentos determinados por certa circunstância mental e moral; acaba-se conhecendo o fragmento mas perde-se, ao mesmo tempo, a verdade. Somente o esoterismo pode explicar o fragmento e recuperar a verdade perdida, referindo-se à verdade total, assim como dar respostas que não sejam fragmentárias nem 
comprometidas de antemão por uma linha confessional. Assim como o racionalismo pode tirar a fé, o esoterismo pode devolvê-la. (SCHUON, 1985, p. 2)

Afirmando ainda que

o fato humanamente inevitável de a Intelecção utilizar-se do racionalismo não significa que ela se identifica com este último. Todavia, o raciocínio correto e baseado em dados suficientes pode ser a origem ocasional de uma determinada Intelecção, exatamente como pode sê-lo um símbolo qualquer da natureza ou da arte. O pensamento relativamente adequado, mesmo hesitante, pode dar origem a uma tomada de consciência segundo uma dimensão totalmente diferente do encadeamento das operações mentais, pois, comparado à intelecção, oferece um simbolismo e um ponto de referência; e a função de todo símbolo é romper a camada de esquecimento que envolve a ciência imanente ao Intelecto. A dialética intelectual, assim como símbolo sensível, é um véu transparente que, por ocasião do milagre da relembrança, rasga-se e revela uma evidência que, sendo universal, brota de nosso próprio ser, que não existiria se não fosse Aquele que é. (SCHUON, 1985, p. 5)

Vemos então que a ideia de uma Arte Sagrada e, por consequência, de uma Música Sagrada, por pretender alcançar o espectador para além de sua compreensão racional, passa pela questão da manifestação formal e simbólica de determinada visão espiritual, muito mais ligada ao seu fundamento esotérico do que ao seu aspecto exotérico.

A esse respeito, Daniélou escreve sobre o sagrado entendendo que

essencialmente, o sagrado se origina com o reconhecimento de uma consciência direcionada para além das formas aparentes. Os elementos que revelam ou "simbolizam" esta consciência representam a lógica interna subjacente à aparência das formas criadas. Eles são comuns aos diferentes aspectos do mundo manifesto e expressam certa informação sobre a modalidade criativa. Tais elementos podem, assim, servir como intermediários entre a humanidade e o pensamento divino, do qual o mundo criado é uma expressão. ${ }^{189}$ (DANIÉLOU, 2003b, p. 15)

E para ampliarmos o entendimento da sintonia de Daniélou com o pensamento que discorremos acima sobre o símbolo, citamos aqui a continuação do parágrafo acima:

Este é o motivo pelo qual o sagrado vive através dos símbolos, aos quais valores mágicos são atribuídos, uma vez que eles criam a possibilidade de

\footnotetext{
${ }^{189}$ Essentially, the sacred originates with the recognition of a directing consciousness beyond apparent forms. The elements that reveal or "symbolise" this consciousness represent the inner logic underlying the appearances of created forms. They are common to the different aspects of the manifest world and express certain data about the creative modality. Such elements may thus serve as intermediaries between mankind and divine thought, of which the created world is an expression.
} 
uma ligação com o divino. Na verdade, tais símbolos devem corresponder a certos dados básicos a respeito da estrutura do universo. Se eles são meramente convencionais, nós entramos no domínio do falsamente sagrado. De fato, a permanência e universalidade de certos símbolos, bem como sua utilização em ritos eficazes, significam que eles podem ser considerados como interpretações precisas dos processos de manifestação da mente do Criador, como indicações das estruturas que influenciam os estados de ser sobrenaturais que se mostram através de certos aspectos do criado. ${ }^{190}$ (DANIÉLOU, 2003b, p. 15-16)

Vemos aqui uma nova convergência do pensamento de Daniélou com a ideia de Burckhardt sobre o símbolo como representação do sagrado, como possuindo uma ligação que vai além da mera convenção e com Schuon ao entender o símbolo como capaz de trazer ao homem a possibilidade de romper o "camada de esquecimento" criando "a possibilidade de uma ligação com o divino".

Embora se trate de uma longa citação, reproduzimos abaixo mais um trecho do texto The origin of sacred music em que podemos ver como Daniélou traz e traduz estas ideias para o domínio musical:

Como afirmado por todos os filósofos da antiguidade, sejam Hindus, Gregos, Egípcios ou Chineses, é no som não articulado - e nas formas musicais em particular - que nós encontraremos a chave mais óbvia para os símbolos e para os meios de comunicação com o sobrenatural, uma vez que o som é a mais abstrata de nossas percepções e o som musical é a forma mais abstrata de expressão sonora.

É na música que nós podemos perceber as razões numéricas diretamente, que nós sentimos como valores expressivos, ideias ou movimentos. Nas estruturas musicais, nós podemos encontrar assim a chave para as relações que unem as abstrações qualitativas e quantitativas expressas por razões numéricas de um lado, e pelas estruturas da matéria, vida, pensamento e sensação de outro. De fato, relações, harmonias, parecem ser a única realidade básica de toda matéria e de toda aparência. Seja nos átomos ou nos sistemas estelares, na formação de cristais ou no desenvolvimento de seres vivos, tudo pode ser remetido para as relações de força que podem ser expressas por dados numéricos proporcionais. Os mecanismos de nossas percepções, ou de nossas reações emocionais utilizadas para perceber e reagir ao mundo exterior, necessariamente seguem leis paralelas. É em tais bases que os filósofos Hindus concluíram que matéria e pensamento são idênticos, o mundo sendo um sonho divino percebido como uma realidade, e a matéria sendo meramente aparência.

As estruturas sonoras, nas quais a vibração física reúne sentimento emocional e pensamento são, assim, tanto a mais poderosa ferramenta para o

${ }^{190}$ This is why the sacred lives through symbols, to which magical values are attributed, since they create the possibility of a link with the divine. In actual fact, such symbols must comply with certain basic data concerning the structure of the universe. If they are merely conventional, we enter the domain of the falsely sacred. In fact, the permanence and universality of certain symbols, as well as their utilisation in efficacious rites, means that they may be considered as precise interpretations of the processes of manifestation of the Creator's mind, as indications of the structures that influence the supernatural states of being that show through certain aspects of the created. 
mundo sobrenatural além da percepção manifestar-se, quanto ao mesmo tempo os meios através dos quais a humanidade pode tornar-se consciente do mundo sobrenatural e ser integrado nele. ${ }^{191}$ (DANIÉLOU, 2003b, p. 1617)

Tal relação do sagrado com a arte e a música encontra seu equivalente na disciplina conhecida como Geometria Sagrada. Não por acaso, trata-se de uma disciplina que pertencia ao Quadrivium, assim como a música. A geometria está para o espaço assim como a música está para o tempo ${ }^{192}$.

Diferentemente da música, que proporciona uma percepção direta, mas exige uma atenção durante sua ocorrência em tempo real, a geometria, por trabalhar graficamente, proporciona uma apreciação mais controlável - porque fixa e visual - daquilo que defende Burckhardt para as artes em geral e por Alain Daniélou especificamente para a música: as proporções formais.

Entre os autores que publicaram trabalhos sobre esta atividade, chama a atenção o livro Geometria Sagrada: filosofia e prática (1996) escrito por Robert Lawlor, pois como afirma Daniélou em sua autobiografia, “dois jovens americanos, Robert Lawlor e Deborah Lawlor, [...] empreenderam recentemente traduções inglesas de vários dos meus trabalhos"193 (DANIÉLOU, 1987, p. 236-237). Além disso, Robert Lawlor foi responsável pela introdução da versão em inglês do livro de Daniélou Virtue, success, pleasure, and liberation: the four aims of life in the tradition of the ancient India (Virtude, sucesso, prazer e liberação: as

${ }^{191}$ As stated by all the philosophers of antiquity, whether Hindu, Greek, Egyptian or Chinese, it is in nonarticulated sound - and the forms of music in particular - that we shall find the most obvious key to symbols and to the means of communication with the supernatural, since sound is the most abstract of our perceptions and musical sound is the most abstract form of sound expression.

It is in music that we can directly perceive numerical ratios, which we feel as expressive values, ideas, or movements. In musical structures, we may thus find the key to the relationships that unite the qualitative and quantitative abstractions expressed by numerical ratios on one side, and by the structures of matter, life, thought and sensation on the other. Indeed, relationships, harmonies, appear to be the only basic reality of all matter and all appearance. Whether atoms or stellar systems, the formation of crystals or the development of living beings, all can be traced back to the relation of powers that can be expressed by numerical facts. The mechanisms of our perceptions or of our emotional reactions used to perceive and react to the external world, necessarily follow parallel laws. It is on such bases that Hindu philosophers have concluded that matter and thought are identical, the world being a divine dream perceived as a reality, and matter being merely appearance.

Sound structures, in which physical vibration reunites emotional feeling and thought, are thus both the most powerful tool for the supernatural world beyond perception to manifest itself and at the same time the means through which mankind can become aware of the supernatural world and be integrated with it.

${ }^{192}$ No Quadrivium identifica-se a Aritmética com o número, a Geometria com o número e o espaço, a Música com o número e o tempo, e a Astronomia com o número, o espaço e o tempo. "A aritmética, a geometria e a música correspondem às três condições existenciais: o número, o espaço e o tempo. A astronomia, que é essencialmente uma ciência dos ritmos cósmicos, engloba todos esses domínios." (BURCKHARDT, 2004, p. 97)

${ }^{193}$ Two young Americans, Robert and Deborah Lawlor, [...] have recently undertaken an English translation of several of my works. 
quatro metas da vida na tradição da antiga Índia). Há, portanto, uma sintonia entre o trabalho destes dois autores.

Lawlor entende a Geometria Sagrada como uma metáfora da ordem universal. Trata-se de uma antiga disciplina que

não repousa em axiomas ou presunções apriorísticas. Contrariamente aos euclidianos e à geometria mais recente, o ponto de partida do antigo pensamento geométrico não é uma rede de definições ou de abstrações intelectuais, mas uma meditação sobre uma unidade metafísica, seguida de uma tentativa por simbolizar visualmente e contemplar a ordem pura e formal que surge desta incompreensível unicidade. É o enfoque do ponto de partida da atividade geométrica o que separa radicalmente o que podemos denominar de geometria sagrada, da mundana ou secular. A geometria antiga começa com o um e as geometrias modernas começam com o zero. (LAWLOR, 1996, p. 16 destaques do autor)

Lawlor relata que a ideia e o símbolo que representa o número zero tem sua origem num texto matemático indiano por volta do século VIII de nossa era (LAWLOR, 1996, p. 17), e que "a invenção do zero permitiu que os números representassem ideias que não têm forma. Isto assinala uma mudança na definição da palavra 'ideia', que na Antiguidade era sinônimo de 'forma' e leva implicitamente à geometria"'194 (LAWLOR, 1996, p. 19).

Afirma ainda que

a orientação teológica da mentalidade hindu não permitiu que se colocasse o zero no início das séries. O zero foi colocado depois do 9. Não foi senão em finais do século XVI na Europa, o alvorecer da 'idade da razão', quando o zero foi colocado na frente do 1 , permitindo assim o conceito dos números negativos.

O zero não só se tornou indispensável no sistema matemático em que repousa nossa ciência e nossa tecnologia, como também, implicitamente, se transferiu para a nossa filosofia e teologia, para a nossa maneira de ver a natureza, para nossas atitudes perante nossas próprias naturezas e ao meio ambiente. [...]

A mentalidade racionalista ocidental negou o antigo e venerado conceito espiritual da unidade, já que com a adoção do zero, a unidade perde sua primeira posição e torna-se meramente uma quantidade entre outras quantidades. $[\ldots]$

[...] O zero continuou orientando a visão do mundo decimonômico, mediante a ideia de que existe uma separação entre o quantitativo e o não quantitativo; o grau extremo desta ideia era de que tudo o que é não quantitativo é não existente, isto é zero. (LAWLOR, 1996, p. 19-20)

\footnotetext{
${ }^{194}$ Entendemos aqui que Lawlor refere-se ao vocábulo grego ê̂dos que pode significar essência, ideia, forma gênero e espécie, já os vocábulos latinos seriam species, forma, essentia (GOBRY, 2007, p. 49-51), ver citação de Burckhardt na página 126 acima.
} 
Lawlor exemplifica a diferença entre a noção quantitativa e a qualitativa, que tem a unidade como princípio e não o zero:

Nosso pensamento atual se baseia na seguinte sequência numérica e lógica:

$$
-5,-4,-3,-2,-1,0,1,2,3,4,5
$$

Com o zero ao centro, há uma expansão quantitativa: $1,2,3 \ldots$, e nosso sentido do equilíbrio exige que haja $-1,-2,-3 \ldots$ do outro lado, o que dá uma série de abstrações não existentes (quantidades negativas) que requerem uma lógica absurda. O sistema tem um ponto de ruptura, o zero, que desconecta o contínuo e dissocia os números positivos da série negativa que o equilibra.

Na progressão numérica do antigo Egito, que começava por um em vez do zero, todos os elementos são naturais e reais:

$$
1 / 5,1 / 4,1 / 3,1 / 2,1,2,3,4,5
$$

Todos os elementos surgem da unidade central de acordo com a lei da inversão e da reciprocidade. Os egípcios baseavam suas matemáticas nesta série de números simples e naturais, e realizavam com ela sofisticadas operações, para as quais hoje necessitamos complexas operações algébricas e trigonométricas. (LAWLOR, 1996, p. 21)

Embora longa, achamos necessária esta digressão sobre a Geometria Sagrada numa cadeia de citações de Lawlor, pois assim é possível entender a analogia, o paralelismo ou mesmo a correspondência entre espaço e tempo ou, naquilo que nos interessa, na correspondência entre geometria e música. Lawlor exemplifica esta lei de inversão e reciprocidade concluindo que "podemos verificar a demonstração desta série nas leis físicas do som. A batida sobre uma corda, ao dividi-la em dois, produz uma frequência dupla de vibrações. Assim esta série expressa a lei essencial da harmonia" (LAWLOR, 1996, p. 21).

Lawlor refere-se aqui ao intervalo de oitava, que é a relação entre duas notas que se encontram em proporção de 2:1. A metade de uma corda $\left({ }^{1} / 2\right)$ tem um som que é o dobro $(2 / 1)$ da frequência da corda inteira.

O som da oitava tem a estranha característica de ser da mesma qualidade que o tom fundamental, ao ponto de que parece fundir-se com ele, mas é de um registro muito mais agudo. A experiência de ouvir a oitava contém o mistério da simultaneidade entre a igualdade e a diferença. Esta qualidade de perceber ao mesmo tempo a igualdade e a diferença faz parte do equilíbrio espiritual que a geometria sagrada pretende cultivar: aquele que precisamente discerne e ao mesmo tempo integra harmoniosamente. (LAWLOR, 1996, p. 82)

Para concluirmos esta comparação entre geometria e música, é impossível não 
reconhecer a importância de Platão, relatada aqui por Ricardo Rizek:

Torna-se, portanto, impossível desmerecer as consequências técnicoartesanais e estético-artísticas da ciência da harmonia, assimilada e transmitida por Platão, quando nos damos conta de que as mesmas proporções numéricas simples, das quartas e quintas justas, ouvidas musicalmente por exemplo, em um organum, podem ser encontradas nas mesmas catedrais para as quais tais músicas foram criadas. Podem ser encontradas, tomando um caso específico, no teto da catedral de Notre-Dame (se incluímos o intervalo de oitava aos anteriores); para não citarmos o contundente caso da catedral de Chartres, considerada, pela hermenêutica tradicional, o Timeu em pedra, ou seja, considerada a transmutação arquitetural de todas as proporções da escala musical abordadas no mais pitagórico diálogo de Platão, parcialmente dedicado à teoria da harmonia. (RIZEK, 2003, p. 3)

A partir de todas estas exposições é possível entender o quão próximo o trabalho de Daniélou sobre música se aproxima desta acepção de Arte Sagrada, como uma atividade que ressoa os princípios universais e as leis naturais, por ser um símbolo que possui uma ligação direta com aquilo que é simbolizado ou, repetindo aqui a citação de Burckhardt ao referir-se a Coomaraswamy a respeito do símbolo:

É preciso que se tenha em mente que um símbolo não é apenas um sinal estabelecido convencionalmente, mas manifesta seu arquétipo em virtude de uma lei ontológica definida; como Coomaraswamy observou, um símbolo é, de certo modo, aquilo que exprime. ${ }^{195}$ (BURCKHARDT, 2004, p. 19 destaque do autor)

Tendo feito esta exposição sobre a Música Sagrada, cabe agora observarmos o fenômeno conhecido por Sacralização da Música.

Tal fenômeno se dá pelo entrelaçamento de três circunstâncias históricas: o Romantismo, o culto ao gênio e - embora aparentemente paradoxal - a secularização da música, que acabam engendrando ideia de música absoluta e consequentemente a defesa de sua autonomia.

Em seu livro O triunfo da música (2011), Tim Blanning nos dá uma noção histórica e sociológica das circunstâncias acima descritas, no entanto, para o que nos interessa aqui, tentaremos nos ater ao que diz respeito exclusivamente à música para que possamos comparála com a acepção de Música Sagrada, porém não nos furtaremos a adentrar nos referidos assuntos quando, e se, se mostrar necessário.

${ }^{195}$ Cf. p. 125 acima 
O que se define como Romantismo, ao menos para a história da música, compreende o período que vai aproximadamente de 1810 a 1900. Trata-se de um período marcado pela valorização do subjetivo, da intuição e de uma valorização da natureza como uma espécie de contraponto ao pensamento racionalista, e segundo Blanning, fortemente influenciado pela filosofia de Jean-Jacques Rousseau (1712-1778), cujo "serviço mais importante à música foi dar uma contribuição crucial à grande revolução romântica que abalou a cultura europeia até as bases no final do século XVIII e início do século XIX” (BLANNING, 2011, p. 106).

Em 1749, Rousseau tem uma espécie de epifania ao ler o anúncio de um concurso de ensaios sobre a pergunta: "O progresso das ciências e das artes ajudou mais a corromper ou a melhorar os costumes?”. Segundo Blanning foi uma espécie de conversão: “as vendas de seus olhos tendo sido retiradas, pôde ver que a civilização não passava de uma gigantesca fraude, perpetrada pelos grandes ricos e poderosos para manter a humanidade oprimida num estado de servidão", pois, "ao descobrir as leis mecânicas do universo, os cientistas naturais haviam apenas revelado novas maneiras de explorá-lo" (BLANNING, 2011, p. 107).

Escreveu seu Discurso sobre as ciências e as artes em 1750 e recebeu o prêmio da Academia de Dijon, porém

\footnotetext{
Rousseau agora se voltava de forma vingativa contra seus amigos philosophes. Contra a razão defendeu a paixão; contra a lógica, a intuição; contra o universal, o particular; contra a dúvida, a fé; contra a civilização, a natureza. Acima de tudo defendeu a introspecção como única fonte autêntica de inspiração. [...]

[...] O fundador da racionalidade esclarecida, Descartes, havia defendido como seu axioma central a necessidade de 'afastar a mente dos sentidos'. Rousseau propôs o contrário. (BLANNING, 2011, p. 107)
}

Este texto de Rousseau exerceu grande impacto nos países de língua alemã:

o Discurso abriu caminho para o Sturm und Drang (Tempestade e Ímpeto) da década de 1770. Durante sua breve vida, esse movimento de jovens insatisfeitos liderado por Goethe e Herder refulgiu tão intensamente que reduziu a cinzas o antigo consenso sobre padrões estéticos. Subjetivismo, excesso emocional, espontaneidade, violência e até certo tipo de anarquismo deixaram de ser desaprovados, passando a se bem-vindos e encorajados (BLANNING, 2011, p. 108)

Com relação à música, por volta de 1800, muitos compositores começam a trabalhar a partir de uma nova estética "que substitui a mimese (arte em relação à natureza) por uma 
teoria expressiva (arte em relação ao artista)"196 (NEUBAUER, 1986, p. 5).

Temos aqui portanto, introspecção e subjetivismo como verdadeiras fontes de inspiração, a ponto de M. H. Abrams criar uma metáfora em que afirma que "a arte mudara de espelho para lâmpada, já não refletindo o mundo natural externo, mas brilhando dentro da mente e coração do criador" ${ }^{\prime 197}$ (apud BLANNING, 2011, p 109). Desse modo há uma valorização cada vez maior do artista em sua individualidade, de forma que "para que tenha valor, uma obra de arte deve vir de dentro do artista, deve ser individual, pessoal, original, espontânea e autêntica” (BLANNING, 2011, p. 109).

Contemporaneamente a essa estética da expressão, temos o culto do gênio, de forma que a palavra gênio deixa de designar a essência de algo para caracterizar o artista criativo. Blanning cita Herbert Dieckmann numa paráfrase ao afirmar que ao fim do século XVIII, “'gênio' deixou de ser um atributo e se tornou a pessoa inteira: possuir gênio era ter um talento excepcional, mas ser um gênio era algo sobre-humano" (DIECKMANN apud BLANNING, 2011, p. 110 destaque do autor).

Dito isso,

\begin{abstract}
faltava um ingrediente final para que o super-homem musical pudesse emergir. A sacralização, processo pelo qual a cultura perdeu sua função representativa e recreativa, tornando-se uma atividade a ser adorada por si mesma. De novo, foi durante as décadas de meados do século XVIII que essa evolução crucial começou. Em seu núcleo estava sua aparente oposição: a secularização. À medida que as formas tradicionais de religião recuaram, um crescente número de intelectuais começou a procurar em outras partes o sustento metafísico e espiritual. De um instrumento da glória de Deus a arte foi gradualmente promovida à própria divindade. (BLANNING, 2011, p. 110 destaques nossos)
\end{abstract}

Passando pela valorização do gênio Beethoven, esta sacralização da música atinge seu auge com Wagner, que não apenas construiu um teatro para a representação de suas óperas mas, “em Arte e revolução (1849) ${ }^{198}$, ele afirmou que só a obra de arte total, incorporando dança, música, teatro dramático e poesia, poderia redimir a humanidade do abismo em que mergulhara" (BLANNING, 2011, p. 120). "Em outras palavras, Wagner reivindicava para a arte a função antes exercida pela religião e usurpada nos tempos modernos pela política ou economia" (BLANNING, 2011, p. 123).

Vemos aqui a diferença entre a Música Sagrada e a Sacralização da Música: enquanto

\footnotetext{
${ }^{196}$ which replaces mimeses (art in relation to nature) by an expressive theory (art in relation to the artist)

${ }^{197}$ Sobre a música como espelho da realidade ou especulativa ver, nesta Parte 2, o capítulo anterior 1.1 Música

Especulativa x Especulação Musical

${ }^{198}$ WAGNER, Richard. A arte e a revolução. Lisboa: Antígona, 1990.
} 
a primeira é de alguma maneira aquilo que é possível transmitir de uma determinada verdade espiritual, ainda que possa estar em desacordo aparente com seu aspecto externo, ou seja, ela está ligada ao aspecto esotérico mais do que ao exotérico, a segunda - a sacralização da música - procura fazer com que a própria música substitua a religião.

Mário Videira em seu livro $O$ romantismo e o belo musical (2006) nos dá mais exemplos deste processo de sacralização da música ao nos dar a conhecer o pensamento de três autores alemães: "Wilhelm Heinrich Wackenroder (1773-1789), Ludwig Tieck (17731853) e E. T. A. Hoffmann (1776-1822)" (VIDEIRA, 2006, p. 71).

Videira nos mostra que para Wackenroder

a música constitui-se na arte que sem dúvida "age sobre nós com tanto mais força $[. .$.$] quanto mais obscura e misteriosa é sua linguagem". A essa força$ misteriosa da música, Wackenroder associa o atributo de "divindade da arte". (apud VIDEIRA, 2006, p. 72)

Além disso, Wackenroder considera que as sinfonias para orquestra "deviam ser ouvidas com tanta devoção, "como se [se] estivesse na igreja”" (apud VIDEIRA, 2006, 73).

Por sua vez, Tieck também encontra na música este aspecto religioso, e Videira cita Rita Iriarte que nos mostra que "Tieck considera a música como 'a mais obscura de todas as artes', e é por essa obscuridade que ele a considera como “o mistério último da fé, a mística, a religião totalmente revelada'" (apud VIDEIRA, 2006, 76)

Por fim E. T. A. Hoffmann afirma que "a essência mesma da música faz dela [...] um culto religioso" (HOFFMANN apud VIDEIRA, 2006, p. 77)

Videira conclui afirmando que

grande parte das ideias contidas nos textos destes três autores exerceu vasta influência sobre muitos dos mais importantes textos escritos sobre a música durante o romantismo, de maneiras diversas e por vezes até contraditórias. A religiosidade exacerbada e a valorização do inefável opõem-se claramente às exigências laicas e racionalistas predominantes durante a maior parte do século XVIII. Se antes a música instrumental era condenada por sua falta de um conteúdo claramente definido, por ser meramente "um luxo inocente", nos textos desses autores encontramos uma total transformação da escala de valores, e a música instrumental, justamente por seu assemantismo, é alçada à condição de uma linguagem capaz de exprimir o que fica além das palavras. (VIDEIRA, 2006, p. 77)

Entendemos assim que a Sacralização da Música está ligada à questão da audição musical e de sua apreciação, enquanto a Música Sagrada diz respeito ao fazer musical e suas relações extramusicais. Se utilizássemos a divisão ternária de Molino e os termos muito 
utilizados por Nattiez, diríamos que a Sacralização da Música encontra-se num nível estésico, enquanto a Música Sagrada remete ao nível poiético. Desse modo, notamos que a acepção musical de Daniélou, por aproximar-se da ideia de Música Sagrada engendra aberturas à criação musical, à busca possível de uma nova música.

\subsection{Ethos, afetos e sentimentos}

No subcapítulo 2.4. Música e Metafísica em Alain Daniélou da Parte 1 afirmamos que a ideia de Daniélou a respeito dos efeitos possíveis da música estaria mais próxima do Ethos grego do que da Teoria dos Afetos barroca ou da Expressão dos Sentimentos romântica [p. 91 acima]. Esse é o assunto principal de seu livro Sémantique Musicale (1993), que trata dos possíveis significados musicais como consequência dos efeitos intervalares em nosso aparelho áudio-mental.

Faremos aqui uma exposição destas três diferentes acepções da música vista como um fenômeno heterônomo - doutrina do ethos, teoria dos afetos e expressão dos sentimentos cuja função estaria fora da música, esta não teria o estatuto de arte autônoma cuja fruição se desse apenas por sua beleza intrínseca.

Embora estas estejam situadas em tempos e espaços diferentes, nossa proposta de compará-las com o pensamento de Daniélou é justamente para mostrar que este não deve ser lido de maneira anacrônica, como se fosse uma releitura ou derivação de uma dessas três acepções. Trata-se de um pensamento de seu tempo com todos os defeitos e virtudes dele decorrentes.

Começaremos no sentido inverso ao do título do subcapítulo, dessa maneira podemos continuar o assunto que terminou o subcapítulo anterior, que se referia a uma forma de entender a música pertencente ao período romântico, assim como o é a expressão dos sentimentos. Em seguida discorreremos sobre a Teoria dos Afetos e depois sobre a Doutrina do ethos. Por fim mostraremos como interpretamos o pensamento de Daniélou em comparação com estas acepções.

Como dito acima, no subcapítulo anterior, o período romântico na música é caracterizado por uma valorização do subjetivo, da introspecção, da intuição da individualidade, da originalidade, da natureza, da paixão; além disso carrega também o culto do gênio, visto não como algo que alguém possui, que o tornaria uma pessoa talentosa, mas 
sim algo que o indivíduo é, aquilo que o torna praticamente sobre-humano; junte-se a isso a sacralização da música e temos esta arte vista como uma espécie de substituto da religião; somado ao fato de que no período romântico - com consequências até nossos dias - a música era entendida como a mais sublime das artes, a arte superior à poesia, aquela que vai aonde as palavras não podem ir.

Deste modo, temos uma valorização paulatina da música instrumental, que não ficaria presa às amarras de um texto, como nos mostra Videira:

Para que o valor atribuído à música instrumental se invertesse em relação àquele que lhe era atribuído pela estética do século XVIII, a concepção de música como uma "linguagem além da linguagem", capaz de exprimir o inefável, o reino do infinito, foi de crucial importância. (VIDEIRA, 2006, p. 79)

Como consequência deste contexto, e no nosso entender principalmente por conta do culto ao gênio, há a ideia de que a música serve como veículo para a expressão dos sentimentos, sentimentos estes que são transmitidos à partitura pelo compositor - o gênio - e que posteriormente ganham vida na execução do intérprete - muitas vezes também entendido como gênio, principalmente pela virtuosidade - chegando por meio de sua interpretação aos ouvintes.

Pois,

a partir do Sturm und Drang e da estética do gênio, começou o declínio dessa representação objetiva de afetos, que foi substituída pela expressão de sentimentos do compositor. Já por volta de 1750 os afetos começaram a ser identificados não mais com estados emocionais racionalizados, mas sim com emoções pessoais, subjetivas, originadas no compositor (VIDEIRA, 2006, p. 63)

Como podemos ver na definição que Hegel (1770-1831) dá à música: "Daí que a alma, o espírito em sua unidade imediata, em sua subjetividade, o coração humano, a pura impressão, constitua a essência mesma desta arte"199 (apud FUBINI, 2001b, p. 267).

Embora tenha sido veementemente contestada por alguns, principalmente pelo crítico Eduard Hanslick (1825-1904) na sua famosa obra Do Belo Musical: um contributo para a revisão da estética da arte dos sons, publicado em 1854, a estética da expressão dos sentimentos ganhou na prática um status de senso comum, de modo que até os dias de hoje a

\footnotetext{
${ }^{199}$ De aquí que el alma, el espíritu en su unidad inmediata, en su subjetividad, el corazón humano, la pura impresión, constituya la esencia misma de este arte
} 
ideia de que o compositor ou o intérprete transmite os seus sentimentos através da música, e que este seria seu principal objetivo, é muito acreditada, ao ponto de observarmos na música que é costumeiramente veiculada em nossos meios de comunicação, uma valorização desta "originalidade" e "dom" musicais. No entanto, entendemos mais como a advertência dada por Dahlhaus, que afirma:

A asserção de que a música é ou deve ser "emanação do coração" corre o risco de se tornar a justificação e o pretexto de um diletantismo entusiástico que considera a sua insuficiência técnico-compositiva como vantagem, em vez de a percepcionar como deficiência. (DAHLHAUS, 2003, p. 35)

Isto porém não chega a ser novidade, pois como afirma Fubini a respeito da primeira metade do século XIX, "uma das características comuns a muitos escritos sobre a música deste período é o tom literário e, no entanto, não especializado"200 (FUBINI, 1996, p. 104).

Porém, ao contrário da hipervalorização da canção em nossos dias, os compositores românticos entendiam que a música instrumental seria o melhor veículo para a expressão dos sentimentos,

portanto, o esforço dos românticos é o de encontrar um âmbito expressivo próprio à música, graças ao qual ela encontre não só uma diferenciação mas também um privilégio com relação às outras artes. A música instrumental pura, apropriada por causa de sua pureza e de manter-se alheia à mistura com outros tipos de expressão, torna-se o símbolo desta nova linguagem privilegiada que permite o acesso a regiões do ser de outro modo inacessíveis. ${ }^{201}$ (FUBINI, 1996, p. 100)

Com relação à Teoria dos Afetos, trata-se de uma teoria que inicialmente dependia do texto, pois marca a passagem da música do Quadrivium para o Trivium, assumindo aos poucos determinados procedimentos reservados à eloquência e ao discurso verbal, que se apoiava nas figuras da retórica, arte integrante do Trivium, para envolver a plateia e produzir determinados efeitos que amplificassem o poder de convencimento do discurso.

Como suporte para o texto, procurava-se fazer com que a música realçasse o tipo de afeto que o texto expunha, dessa maneira é inevitável que determinadas palavras ou

\footnotetext{
${ }^{200}$ una delle caratteristiche comuni a molti scritti sulla musica di questo periodo è il tono letterario e comunque non specialistico

${ }^{201}$ Pertanto lo sforzo dei romantici è di trovare un ambito espressivo proprio alla musica, grazie al quale essa trovi non solo una differenziazione ma anche un privilegio rispetto alle altre arti. La musica strumentale pura, proprio per via della sua purezza e del suo mantenersi aliena da commistioni con altri tipi di espressione, diventa il simbolo di questo nuovo linguaggio privilegiato che ci permette l'accesso a regioni dell'essere altrimenti inaccessibili.
} 
expressões assumissem figuras musicais constantes, de forma que começa a se cristalizar determinados clichês musicais, que podem ser assimilados como representações de determinados afetos, podendo-se desta maneira utilizá-los numa música que não tenha um texto, representando determinados afetos mesmo numa música puramente instrumental.

Ou seja, como nos diz Videira, "a partir do estabelecimento de tal convenção é que foi possível a utilização desse repertório de figuras na música instrumental, independentemente de qualquer texto" (VIDEIRA, 2006, p. 59). Ou, como afirma Harnoncourt,

um verdadeiro vocabulário de figuras musicais que possuíam sentido determinado e eram familiares a todo ouvinte culto. Foi a partir daí que se pôde chegar ao corolário, isto é, utilizar-se também este repertório de figuras independentemente, sem qualquer texto: graças somente à figura musical, o ouvinte faria a associação com a linguagem. (HARNONCOURT, 1998, p. 170).

Porém, como num teatro em que se não se sabe a língua que se fala, o seu entendimento é deveras prejudicado se não se conhece os códigos que estabelecem a representação de determinados afetos, por mais precisamente bem executado que possa ser a interpretação musical.

A valorização da música instrumental - pois até então esta servia apenas à dança ou ao entretenimento - e o seu reconhecimento como forma artística válida se dá, principalmente na cultura alemã, a partir do período Barroco que se estende aproximadamente de 1600 a 1750 . Pouco a pouco a música se descola da necessidade de ser apoio para um texto e passa a ter valor autônomo, passando a ser puramente instrumental, o que leva pouco a pouco ao conceito de música absoluta ou música pura.

Este descolamento do texto, proporcionado pela simbolização da palavra pela música que aos poucos passa a representar diretamente o afeto ligado à palavra, sendo desnecessário a palavra para ligar o afeto à música, proporciona uma música instrumental que representa os afetos da mesma maneira que estes seriam representados num determinado texto ou discurso.

Pois, como aponta Dahlhaus,

a doutrina dos afetos, por muito que salientasse o efeito da música, o movimento do ânimo, pressupunha implicitamente uma concepção, antes de mais, objectivadora das características sentimentais musicais. (DAHLHAUS, 2003, p. 30 destaque nosso)

No entanto, a diversidade de convenções e a não unanimidade com respeito às representações dos afetos - pois não existia apenas uma Teoria dos Afetos, e sim várias 
teorias desenvolvidas para representá- $\operatorname{los}^{202}$ - tornam tais representações puramente convencionais, pois se trata de uma representação dos afetos, e o efeito assim desejado, de mover os afetos com a música, corre o risco de tornar-se algo de natureza muito mais subjetiva do que objetiva, mais individual do que coletiva, pois seria preciso conhecer todas as convenções existentes para saber exatamente o afeto representado para que o ouvinte o reconhecesse e produzisse o efeito desejado pelo compositor.

Por sua vez, a Doutrina do Ethos, que remonta à pré-história da música ocidental tendo origem na Grécia, normalmente é entendida como uma possibilidade de provocar determinados efeitos no ouvinte, de forma que ele passaria a se comportar de acordo com o tipo de música que estivesse sendo tocada. Para esse efeito ser mais efetivo, importava determinados fatores que atuariam de maneira conjunta. Ia desde o modo utilizado até os tipos de instrumentos, se era uma música com texto ou instrumental, se era tocada por um instrumento de sopro ou de corda, e assim por diante.

Não por acaso, as palavras ética e etiqueta derivam da palavra ethos que significa hábito, comportamento, conduta, além de morada (cf. BOFF, 2003). Deste modo, entendemos que os possíveis efeitos causados pelos ethos musicais, não seriam assim tão mágicos como se quer fazer supor. Como por exemplo no relato de Fubini, que ora é atribuído a Damon ora a Pitágoras:

De acordo com esta história, alguns jovens, vítimas da embriaguez do vinho e excitados, como frequentemente acontecia, pela melodia de uma flauta, estavam a ponto de entrar na casa de uma mulher de bons costumes; nesse preciso instante, a intervenção de Pitágoras (ou de Damon), dando ordem ao flautista de executar uma melodia no modo frígio (o canto das libações ou Spondeion), produziu um efeito imediato sobre os jovens, que, reparando na agitação que os tomava, renunciaram aos seus propósitos sob o efeito da lentidão e solenidade da melodia. ${ }^{203}$ (FUBINI, 2001b, p. 57)

Ao entender o ethos como morada, hábito, conduta ou costume, é impossível não

\footnotetext{
${ }^{202}$ Videira chama a atenção a este detalhe numa nota de rodapé que reproduzimos em parte aqui: "Embora muitos estudos sobre música barroca publicados a partir do século XIX façam inúmeras referências a uma Doutrina dos afetos (Affektenlehre), nunca se estabeleceu de fato na teoria barroca nenhuma doutrina ampla e organizada de como realizar os afetos em música" (VIDEIRA, 2006. p. 58n). E, assim como Videira, utilizaremos o termo Teoria dos Afetos neste texto "devido ao seu uso já consagrado e corrente na musicologia" (VIDEIRA, 2006. p. 58n).

${ }^{203}$ Según tal relato, algunos jóvenes, víctimas de la embriaguez del vino y excitados, como sucedía a menudo, por la melodía de una flauta, estaban a punto de traspasar la puerta de la casa de una mujer de rectas costumbres; en ese preciso instante, la intervención de Pitágoras (o de Damón), dando orden a la flautista de ejecutar una melodía en la tonalidad frigia (el canto de las libaciones o Spondeion), produjo un efecto inmediato sobre los jóvenes, que, reparando en la agitación que los embargaba, renunciaron a sus propósitos bajo el efecto de la lentitud y solemnidad de la melodía.
} 
pensar que há a necessidade de um contexto, uma morada, onde esses hábitos, costumes ou condutas aconteçam, e que possivelmente haveria uma determinada música que faria parte deste contexto, de modo que ao fim e ao cabo, os efeitos causados no ouvinte podem ser atribuídos à determinada lembrança de determinado contexto evocada pela música, fazendo então que aumente a probabilidade do ouvinte se comportar de maneira similar àquela que ele se comportaria no determinado contexto, manifestando assim seu hábito, costume ou conduta.

Como afirma Fubini,

cada modo tinha de produzir um efeito muito específico sobre o espírito, seja positivo ou negativo; igualmente, cada modo não imitaria exclusivamente um estado de ânimo, mas também os costumes do país em que se originasse e - mais ainda - o tipo de regime político existente: democrático, oligárquico ou tirânico. ${ }^{204}$ (FUBINI, 2001b, p. 57 destaque nosso)

Nota-se aqui que Fubini fala que o modo produziria um efeito por imitar um estado de ânimo. Neste caso, a Doutrina do Ethos pressupõe portanto uma música baseada na mimese, na imitação da natureza, no caso da natureza humana.

Tendo feito estas digressões acima, demarcaremos aqui as principais diferenças do pensamento semântico musical de Alain Daniélou com respeito às diferentes acepções musicais relatadas.

Com relação à expressão dos sentimentos, vemos que a diferença é que Daniélou, por ser envolvido com a música indiana, defende a ideia de que a música evoca determinados climas, estes climas estariam além da mera transmissão dos sentimentos humanos, principalmente os sentimentos de uma pessoa e não o tipo de sentimento que poderia ser comum à humanidade toda. No entanto, em sua juventude Daniélou defendia a execução musical envolvida com aqueles sentimentos que por ventura esta possa suscitar, condenando as interpretações mecânicas e fazendo questão de afirmar seu gosto por Chopin e pelos compositores românticos, como o faz em sua autobiografia:

Havia um piano de armário velho, mas muito bom, numa pequena sala repleta de partituras musicais, onde eu descobri Estudos de Chopin, Années de Pèlerinage de Liszt, Variations Symphoniques de Schumann, e Impromptus de Schubert. Algumas dessas peças permaneceram na minha memória associadas com certas paisagens, efeitos de luz, emoções poéticas, e leituras clandestinas. [...] Minha compreensão da música era uma

${ }^{204}$ cada modo hubo de producir un efecto muy específico sobre el espíritu, ya fuera positivo o negativo; asimismo cada modo no imitaría exclusivamente un estado de ánimo, sino también las costumbres del país en el que se originase y-más aún-la clase de régimen político existente: democrático, oligárquico o tiránico. 
experiência estritamente pessoal: $\mathrm{Eu}$ a sentia como uma coisa viva, uma projeção emocional de mim mesmo. Por esta razão, mais tarde achei muito difícil apreciar a audição de pianistas, embora houvesse algumas exceções Cortot e Rachmaninoff em particular; eu achava a maioria dos outros revoltantes. Os mais famosos pianistas, me pareciam, não entendiam o que estavam tocando. Eles moviam-se pelas passagens mais comoventes sem ver nada, completamente alheios aos toques de emoção musical que são expressos através de certas pausas e ornamentos; eles pareciam não ter senso dos movimentos da composição e corriam através da paisagem musical tão cegamente como um estouro de manada de elefantes. ${ }^{205}$ (DANIÉLOU, 1987, p. 52-53)

É interessante notar na passagem acima que, embora Daniélou fale de emoções, ou de como as peças permaneceram em sua memória, sua crítica aos pianistas refere-se a uma má interpretação do texto musical, como se eles não entendessem como os signos representados deveriam ser tocados de maneira apropriada, faltava-lhes senso de proporção para equilibrar os movimentos, sua crítica não é exatamente à ausência de emoção ou sentimento, ainda que os compare a um “estouro de manada de elefantes", é à ausência de entendimento.

A Teoria dos Afetos de distingue do pensamento de Daniélou por representar os afetos mais do que transmiti-los ou suscitá-los. Esta dependência do conhecimento retórico, ou pelo menos do conhecimento da representação retórica das figuras musicais, para o entendimento dos afetos estaria em desacordo com Daniélou, para quem a música seria uma espécie de linguagem natural que não dependeria das convenções culturais ou linguísticas para o seu entendimento, muito menos para a evocação de afetos.

Daniélou considera a música uma linguagem e aparentemente aí cessa a semelhança possível com a Teoria dos Afetos. Nesta última, como dito acima por Harnoncourt, as figuras musicais "possuíam sentido determinado e eram familiares a todo ouvinte culto" (HARNONCOURT, 1998, p. 170), há a necessidade do conhecimento dos códigos e convenções, enquanto na acepção de Daniélou, a música é uma linguagem, porém uma linguagem natural que se aproximaria não da retórica e sim de outras disciplinas, pois, ainda que ele entenda o universo como sendo composto de vibrações - assim como o entende a

\footnotetext{
${ }^{205}$ There was an old but quite good upright piano in a small room filled with musical scores where I discovered Chopin's Etudes, Liszt's Années de Pèlerinage, Schumann's Variations Symphoniques, and Schubert's Impromptus. Some of those pieces have remained associated in my memory with certain landscapes, light effects, poetic emotions, and clandestine readings. [...] My understanding of music was a strictly personal experience: I felt it as a living thing, an emotional projection of myself. For this reason I later found it very difficult to enjoy listening to pianists, though there were some exceptions-Cortot and Rachmaninoff in particular; I found most of the others revolting. The most famous pianists, it seemed to me, did not understand what they were playing. They would go through the most moving passages without seeing anything at all, completely oblivious to the accents of musical emotion that are expressed through certain pauses and ornaments; they seemed to have no sense of the composition's movements and rushed through the musical landscape as blindly as a herd of stampeding elephants.
} 
física quântica e a cosmologia hindu -, ele atribui a evocação pelo som como consequência de correspondências metafísicas. Reproduzimos aqui uma citação de Daniélou já vista também na página 43:

\begin{abstract}
A evocação através do som, como a própria criação, ocorre não devido ao fato material da vibração física, mas por conta da existência de correspondências metafísicas. Por isso toda explicação psicológica da experiência musical deve ser descartada. $\mathrm{Na}$ realidade, a personalidade do ouvinte não tem nenhuma importância no fenômeno da evocação musical porque a evocação ocorre mesmo se não há ouvinte, e se a existência desta evocação é efêmera é apenas devido à imperfeição da relação dos sons. Ouvintes podem ser diferenciados negativamente apenas com relação à perspicácia de sua percepção, sua maior ou menor surdez. [...] O trabalho do músico consiste portanto, apenas em conhecer, tão precisamente quanto possível, as relações simbólicas de todas as coisas para reproduzir em nós, através da magia dos sons, os sentimentos, as paixões, as visões de um mundo quase real ${ }^{206}$ (DANIÉLOU, 1995, p. 4-5)
\end{abstract}

E um pouco antes, na mesma página 43, a comparação de Daniélou com outras disciplinas: "Nós podemos então entender porque a astrologia, a alquimia, a geometria e assim por diante se expressam em termos de relações harmônicas"207 (DANIÉLOU, 1995, p. 4). Vemos aqui portanto que a acepção de Daniélou é mais próxima do Quadrivium do que do Trivium. ${ }^{208}$

Por fim, consideramos a maneira como Daniélou entende a música como próxima da Doutrina do Ethos, porém há também diferenças a serem demarcadas. O modo hindu como Alain Daniélou entende a música, somada com sua interpretação da música como uma espécie de linguagem natural, a diferencia da Doutrina do Ethos, pois esta, como vimos, estaria ligada ao hábito, aos costumes. Para Daniélou, a evocação de determinados climas pela música não dependeria de hábitos ou costumes, como vimos acima, seriam proporcionados pelos efeitos provindos da combinação dos intervalos devido às correspondências metafísicas.

Por isso, Daniélou - "musicólogo engajado na defesa da música modal” como afirmou

\footnotetext{
${ }^{206}$ Evocation through sound, like creation itself, takes place not because of the material fact of physical vibration but on account of the existence of metaphysical correspondences. Therefore all psychological explanation of musical experience has to be discarded. In reality, the personality of the hearer counts for nothing in the phenomenon of musical evocation because evocation takes place even if there is no hearer, and if the existence of this evocation is ephemeral it is only because of the imperfection of the relation of sounds. Hearers can be differentiated negatively only by the relative acuteness of their perceptions, their great or lesser deafness. [...] The work of the musician consists therefore only in knowing, as accurately as possible, the symbolic relations of all things so as to reproduce in us, through the magic of sounds, the feelings, the passions, the visions of an almost real world.

${ }^{207}$ We can therefore understand why astrology, alchemy, geometry and so forth express themselves in terms of harmonic relations.

${ }^{208}$ Cf. subcapítulos 1.1. Música Especulativa x Especulação Musical e 1.2. Música Sagrada x Sacralização da Música desta Parte 2.
} 
Wisnik (1989, p. 85) - assume esta música como a mais apta a proporcionar estes efeitos e climas que afetariam não apenas os seres humanos, que poderiam estar de antemão sugestionados psicologicamente pela menção a determinadas ideias, mas também os animais e a própria natureza.

Isto se daria porque na música modal não teríamos a modulação, ela repete sempre as mesmas notas nas mesmas alturas - nas mesmas frequências - no decorrer de toda a música, de forma que entre elas dar-se-ia sempre a mesma razão intervalar, movendo não só o ouvinte, mas todo o ambiente onde se executa a música, pois se tratam de ondas sonoras que funcionam como ondas de energia, que devido a correspondências metafísicas poderiam mudar o clima e o estado de determinado lugar e seres vivos presentes.

Por outro lado, como nos mostra Fubini, além do próprio significado de ethos,

todo o pensamento sobre a música dos gregos é dominado pelo tema da relevância ética, positiva ou negativa, da música na sociedade. A questão de se e em quais limites a música pode ser chamada de um elemento educativo do ponto de vista social é fundamental no pensamento grego e representa o núcleo forte, em torno do qual se articula a problemática sobre a relevância ética da própria música. ${ }^{209}$ (FUBINI, 1996, p. 45-46)

Como dissemos acima, na página 141, ao falar sobre a Doutrina do Ethos há a ideia de mimese, como afirma Fubini (2001b, p. 57): "cada modo não imitaria exclusivamente um estado de ânimo, mas também os costumes do país em que se originasse". Por sua vez, há aqui uma semelhança com a acepção de Daniélou, porém sua ideia de imitação estaria mais próxima do que afirma Burckhardt:

\begin{abstract}
A doutrina comum a todas as civilizações tradicionais determina que a arte sagrada deve imitar a arte divina. Contudo, é preciso ficar bem claro que isso não significa, de modo algum, copiar a Criação Divina acabada, isto é, o mundo como o vemos, pois isto seria uma vã pretensão. Um "naturalismo" literal está, portanto, excluído da arte sagrada. O que deve ser imitado é $o$ modo como o Espírito Divino opera. Suas leis devem ser transpostas ao restrito domínio no qual o homem opera, ou seja, ao campo de sua habilidade artesanal. (BURCKHARDT, 2004, p. 21)
\end{abstract}

Entendemos que as semelhanças com a Doutrina do ethos se dá também por outro

${ }^{209}$ Tutto il pensiero sulla musica dei greci è dominato dal tema della rilevanza etica, positiva o negativa, della musica nella società. Il quesito se ed entro quali limiti la musica possa dirsi un elemento educativo dal punto di vista sociale è fondamentale nel pensiero greco e rappresenta il nucleo forte, attorno a cui si articola la problematica sulla rilevanza etica della musica stessa. 
motivo. Em Seu livro Shiva et Dionysos ${ }^{210}$ Daniélou faz um paralelo entre Shiva e Dioniso, como dois deuses - hindu e grego respectivamente - cuja origem remontaria a um mesmo deus, a uma mesma energia anímica, a um mesmo impulso vital, a um mesmo princípio latente:

O Shivaísmo é essencialmente uma religião da natureza. Shiva, como Dioniso, não representa senão um dos aspectos da hierarquia divina, aquele que pertence ao conjunto da vida terrestre. O Shivaísmo, ao estabelecer uma coordenação realista entre os seres sutis e os seres vivos, é sempre oposto ao antropocentrismo das sociedades urbanas. Sua forma ocidental, o Dionisismo, representa o mesmo estado onde o homem está em comunhão com a vida selvagem, com as feras da montanha e da floresta. Dioniso como Shiva é um deus da vegetação, da árvore, da videira. ${ }^{211}$ (DANIÉLOU, 2009, p. 20)

Além disso Daniélou considera a Índia como uma das civilizações mais antigas que ainda guarda traços de sua ancestralidade. E que este paralelo Shiva e Dioniso representa por sua vez uma das religiões mais antigas da humanidade:

Pareceu-me pouco a pouco que tudo o que me parecia válido nas religiões posteriores eram apenas restos parciais, deformados, às vezes desnaturados ou habilmente mascarados, desta sabedoria muito antiga resumida nos cultos de Shiva ou de Dioniso de acordo com a localização, e que esta religião, frequentemente perseguida e sempre renascente, permaneceu a mais moderna e parecia corresponder às necessidades mais profundas do homem de hoje como daquele dos tempos antigos. $\mathrm{O}$ que é às vezes chamado a "Tradição Primordial" pode finalmente se ligar a esta corrente cujas raízes remontam às primeiras eras do mundo. ${ }^{212}$ (DANIÉLOU, 2009, p. 11)

Desse modo, entendemos que a semelhança entre a acepção semântica musical de Daniélou, baseada na teologia hindu - especificamente shivaísta -, assemelha-se à grega não

${ }^{210}$ Este é o único livro de Daniélou publicado no Brasil: DANIÉLOU, Alain. Shiva e Dioniso: a religião da natureza e do Eros. São Paulo: Martins Fontes, 1989. Porém, consultamos para esta tese apenas o original francês.

${ }^{211}$ Le Shivaïsme est essentiellement une religion de nature. Shiva, comme Dionysos, ne représente qu 'un des aspects de la hiérarchie divine, celui qui concerne l'ensemble de la vie terrestre. Le Shivaïsme, en établissant une coordination réaliste entre les êtres subtils et les êtres vivants, $s$ 'est toujours opposé à

l'anthropocentrisme des sociétés urbaines. Sa forme occidentale, le Dionysisme, représente de même un stade où l'homme est en communion avec la vie sauvage, avec les bêtes de la montagne et de la forêt. Dionysos comme Shiva est un dieu de la végétation, de l'arbre, de la vigne.

${ }^{212}$ Il m'est apparu peu à peu que tout ce qui me paraissait valable dans les religions ultérieures n'était que des survivances partielles, déformées, parfois dénaturées ou habilement masquées, de cette très ancienne sagesse résumée dans les cultes de Shiva ou de Dionysos selon les lieux, et que cette religion, souvent persécutée et toujours renaissante, restait la plus moderne et semblait correspondre aux besoins les plus profonds de l'homme d'aujourd'hui comme de celui des temps anciens. Ce que l'on a parfois appelé la "Tradition Primordiale» ne peut finalement se rattacher qu'à cette filière dont les racines remontent aux premiers âges du monde. 
por uma mera coincidência, ou porque a cultura grega teria mais importância para o ocidente e portanto deve ser sempre referendada, mas porque possivelmente as duas culturas partilhariam determinadas visões de mundo, míticas e religiosas, que coincidiriam em muitos aspectos. Sendo assim, não se trata apenas de uma semelhança musical estética ou filosófica, mas também cultural de maneira mais ampla, incluindo neste caso a questão religiosa. 


\section{Teoria Musical}

Colocaremos aqui neste segundo capítulo da Parte 2 a obra de Alain Daniélou em diálogo com a Teoria da Música. Para isso o subdividimos em dois subcapítulos que abordam aspectos da Teoria Musical muitas vezes considerados como secundários, pelo menos para grande parte da música executada atualmente, mas que entendemos como de suma importância não só para entender o trabalho de Daniélou, mas que poderiam abrir novos caminhos para a criação e fruição musical, assim como possibilitar novas descrições sobre o processo histórico musical, abrindo-o assim para novas interpretações

Como já dissemos acima na Parte 1, em que tratamos da exposição da obra de Daniélou, ele se vale da teoria musical de três grandes civilizações para poder compará-las numa base comum, e assim conseguir estabelecer paralelos que possam nos ajudar a entender o percurso da música ocidental a partir deste contexto.

Citamos também acima [cf. p. 101] que Gadamer considera que a filosofia seria o "antigo nome para teoria" (GADAMER, 2001, p. 23 et seq.), por isso entendemos que a forma como Daniélou entende a Teoria Musical está muito próxima desta definição de Gadamer, pois a interpreta como um aspecto metafísico do fazer musical, que seria anterior àquela tradição teórica que Dahlhaus chamaria de Teoria Prática. Esta tradição teórica nos parece atualmente a predominante tanto na abordagem analítica como pedagógica, e Dahlhaus a vê como

a "regulação" e "coordenação" destes sistemas acústicos aplicados à prática composicional. Como uma disciplina regulatória, tal "teoria" musical busca extrair da prática regras normativas de sintaxe e modelos de estruturas, e ao mesmo tempo disciplinar tal prática através de restrições pedagógicas. ${ }^{213}$ (apud CHRISTENSEN, 2004, p. 13-14)

Dahlhaus também vê outra tradição teórica a qual chama de especulativa, que seria a "contemplação ontológica dos sistemas sonoros"214 (DAHLHAUS apud CHRISTENSEN, 2004, p. 13), o que compreenderia entre outras atividades as "pesquisas nas áreas da acústica e teoria da afinação nos séculos XVII e XVIII e psicologia sonora nos séculos XIX e XX"215

\footnotetext{
213 the "regulation" and "coordination" of these tone systems applied to compositional practice. As a regulatory discipline, such music "theory" seeks to draw from practice normative rules of syntax and models of structure, while at the same time disciplining that practice through pedagogical strictures.

${ }^{214}$ ontological contemplation of tone systems

215 research in the areas of acoustics and tuning theory during the seventeenth and eighteenth centuries and tone
} 
(CHRISTENSEN, 2004, p. 13-14). No entanto, entendemos que, de acordo com o que definimos no subcapítulo 1.1. Música Especulativa x Especulação Musical, esta forma de classificação colocaria tanto uma como outra, tanto a Teoria Especulativa quanto a Teoria Prática inseridos naquilo que delimitamos como Especulação Musical, enquanto a forma como Daniélou aborda a teoria estaria mais próxima, embora não completamente inserida, do que delimitamos como Música Especulativa.

Curiosamente, esta abordagem de Daniélou, próxima de definições mais antigas, torna possível aproximá-lo de uma forma atual de abordar a Teoria. Lia Tomás, referindo-se a Edward Lippman nos mostra em seu livro Ouvir o lógos: música e filosofia outra postura relativa à teoria musical, "produto de uma reavaliação da própria musicologia e da estética musical, que começaram a repensar tanto a si mesmas - seu papel e função -, como seus métodos de investigação e análise de seu objeto de estudo, a música” (TOMÁS, 2002, p. 20).

Tomás cita Lippman, que reproduzimos abaixo na tradução da autora:

Essa nova concepção, no entanto, tem um velho ancestral, para voltarmos ao significado grego de teoria como contemplação intelectual, uma abrangente categoria que Aristóteles diferencia em relação à ação e à produção. Nesse sentido, a teoria musical poderia abranger todas as ideias pertencentes à música e poderia opor à existência filosófica, a performance e a composição como atividades, mas não a teoria dessas atividades. Podemos dizer, então, que um ciclo se fechou na história da teoria musical e deixou para trás a tradicional divisão dos estudos musicais. (LIPPMAN, 1993, p. 231)

Entendemos a forma como Daniélou entende a teoria musical como algo muito próximo desta definição pois afirma que

\begin{abstract}
portanto, ao julgar as possibilidades e o valor dos sistemas musicais, não devemos confiar no julgamento preconceituoso de nossos ouvidos, mas considerar em sua forma mais abstrata suas possibilidades teóricas. Nós podemos então descobrir a equivalência de sistemas que a princípio parecem não ter nada em comum. Nós também podemos descobrir uma profunda diferença entre sistemas cujas formas são aparentemente muito similares. Ao fazê-lo nós iremos, em todo caso, julgar os sistemas musicais solidamente e em bases seguras. Para ser capaz de perceber sua beleza ou perceber diretamente seu significado é outra questão e geralmente requer uma prática muito longa.216 (DANIÉLOU, 1995, p. 18)
\end{abstract}

psychology in the nineteenth and twentieth centuries

${ }^{216}$ Therefore, in judging the possibilities and the value of musical systems, we should not trust the prejudiced judgement of our ears, but consider in their most abstract form their theoretical possibilities. We may then discover the equivalence of systems that at first seem to have nothing in common. We may also discover a profound difference between systems whose forms are outwardly very similar. By so doing we shall, in any case, judge the musical systems soundly and on safe grounds. To be able to realize their beauty or directly perceive their meaning is another matter and generally requires very long practice. 
Entendemos que a Teoria Prática - regulatória e gramatical - trata principalmente dos aspectos mais concretos da música: como compor, como representar e escrever ou como interpretar determinado texto musical, enquanto o estudo da teoria musical tal como propõe Daniélou trataria de aspectos mais abstratos e reflexivos e por isso mais filosóficos, aproximando-o da proposta de Lippman.

Daniélou não discute, no entanto, a ideia de discretização do espaço sonoro, por isso sua teoria baseia-se principalmente na maneira pela qual este espaço sonoro é dividido em diferentes fazeres musicais, e como seria possível unificar - por meio desta divisão -, considerando diferentes sistemas musicais como complementares e não como contraditórios, a relação intervalar consequente dessa discretização do espaço sonoro em notas de altura definidas.

Segundo Daniélou “toda música é baseada nas relações entre os sons, e um cuidadoso estudo dos números pelos quais estas relações são governadas nos trás imediatamente para a quase esquecida ciência do simbolismo numérico"217 (DANIÉLOU, 1995, p. 1)

Dito isto, em nosso primeiro subcapítulo, 2.1. Simbolismo: correspondências, trabalharemos com os aspectos simbólicos da música tais como sugeridos por Daniélou em seus trabalhos, embora muitas vezes não abordados de maneira exaustiva.

No segundo subcapítulo 2.2. Matemática: a Escala Universal dos Sons e sua relação com a série harmônica, abordaremos a construção da Escala Universal dos Sons de Daniélou em relação com a série harmônica. Com isso delimitaremos as diferenças entre tônica e fundamental utilizando os acordes maior e menor construídos com parciais da série harmônica, como ponto de partida, passando depois pelas afinações Pitagórica e Justa. Isto nos servirá de base para estabelecer a diferença entre o relativismo do Temperamento Igual e o perspectivismo permitido pela escala de Daniélou por ser construída com intervalos naturais.

Assim como se deu com o subcapítulo 1.1. Música Especulativa x Especulação Musical, também publicamos uma comunicação sobre este tema (CINTRA, 2011), que pretendemos aqui estendê-lo e complementá-lo.

${ }^{217}$ All music is based on the relations between sounds, and a careful study of the numbers by which these relations are ruled bring us immediately into the almost forgotten science of numerical symbolism. 


\subsection{Simbolismo: correspondências}

De que nos serve toda esta grandeza humana, se a nostalgia do Infinito, que nos é inata, não mais encontra resposta? (BURCKHARDT, 2004, p. 251)

Trabalharemos neste subcapítulo com a questão do simbolismo encontrado na música, principalmente aquele que se dá na relação entre as notas, intervalos e números.

Não é nossa intenção aqui fazer uma taxonomia dos símbolos encontrados em cada tradição musical pesquisada por Daniélou, buscaremos aqui, a partir de simbolismos básicos, traçar as correspondências possíveis entre as diversas tradições, principalmente em seus aspectos metafísicos. Embora a ideia mais óbvia seria imaginar que primeiro se tem o som e só depois ele adquire aspectos simbólicos, entendemos que no caso específico da música mesmo que o som possa surgir primeiramente, a organização destes em música só se dá posteriormente, quando adquirem algum tipo de sentido ou significado simbólico e metafísico.

Como afirma Daniélou,

a maior parte dos elementos de nosso sistema musical são relacionados a uma teoria cosmológica milenar e a um simbolismo muito antigo, como são também as raízes e formas de linguagem, instrumento de nosso pensamento, assim como muitas das nossas formas de medir o tempo e o espaço. ${ }^{218}$ (DANIÉLOU, 2004, p. 15 destaque nosso)

Retomamos aqui também Susanne K. Langer em Filosofia em nova chave, que afirma que

na noção fundamental de simbolização - mística, prática, ou matemática, não faz diferença - temos a tônica de todos os problemas humanísticos. Nela, reside a nova concepção de "mentalidade", que ilumina questões de vida e consciência, em vez de obscurecê-las, como fizeram os "métodos científicos" tradicionais. (LANGER, 1971, p. 35 destaques da autora)

Tais simbolizações na música, ao partirem de uma relação direta entre significante e significado, como já nos referimos acima ao citar Sylvia Leite [cf. p. 124 acima] e Titus Burckhardt, referindo-se a Coomaraswamy que afirma que "um símbolo é, de certo modo,

\footnotetext{
${ }^{218}$ La plupart des éléments de notre système et de notre vocabulaire musical sont liés à une théorie cosmologique millénaire et à un très ancien symbolisme comme le sont aussi les racines et las formes du langage, instrument de notre pensée, ainsi que beaucoup de nos manières de mesurer le temps et l'espace.
} 
aquilo que exprime" (BURCKHARDT, 2004, p. 19 destaque do autor) [cf. p. 132 acima] seriam responsáveis por Daniélou afirmar que

a conexão entre a realidade física e os princípios metafísicos pode ser sentida na música como em nenhum outro lugar. A música era, portanto, justamente considerada pelos antigos como a chave para todas as ciências e artes - a ligação entre metafísica e física através da qual as leis universais e suas múltiplas aplicações poderiam ser entendidas. ${ }^{219}$ (DANIÉLOU, 1995, p. 1)

O que entendemos aqui como símbolo não se refere às figuras que representam o som na notação musical, mas sim à ideia que baseia a concepção de discretização do contínuo sonoro e o estabelecimento de relações entre estes elementos discretizados, que a partir de então passam a ser referidos como notas e não mais como sons.

Com o decorrer dos séculos, esta simbologia ou se perde ou passa a não mais fazer sentido, o que nos faz atribuir um caráter arbitrário a essas relações simbólicas, e o que ficaram foram os sinais que são utilizados para notação, os nomes das notas, entre outras coisas que pertencem ao universo da Teoria Prática, responsável pela gramática e regulação da sintaxe musical e dirigida ao aspecto musical sensível. No entanto, a possibilidade de se levantar novamente estes aspectos simbólicos, tornaria possível entender melhor nossa atual forma de ouvir e entender a música, resgatar sua aparente origem e possibilitar uma releitura destes símbolos à luz de nosso conhecimento moderno. Pois, como afirmou Carl Gustav Jung (1875-1961):

O homem moderno é, na verdade, uma curiosa mistura de características adquiridas ao longo de uma evolução mental milenária. E é desse ser resultante da associação homem-símbolos, que temos de nos ocupar, inspecionando sua mente com extremo cuidado. O ceticismo e a convicção científica coexistem nele, juntamente com preconceitos ultrapassados, hábitos de pensar e sentir obsoletos, erros obstinados e uma ignorância cega. (JUNG, 2008, p. 121)

É com relação a estes simbolismos que Daniélou afirma a necessidade de trabalhar com a Teoria Musical, entendida aqui em seu aspecto metafísico, buscando correlações entre sistemas aparentemente diferentes. Como ele entende que o elemento teórico que possibilita esta correlação é a divisão $\operatorname{discreta}^{220}$ do espaço sonoro, toma como base sua divisão

\footnotetext{
${ }^{219}$ The connection between physical reality and metaphysical principles can be felt in music as nowhere else. Music was therefore justly considered by the ancients as the key to all sciences and arts - the link between metaphysics and physics through which the universal laws and their multiple applications could be understood.

${ }^{220}$ Cabe aqui definir a oposição entre os termos discreto e contínuo. Segundo Antonio Carlos Brolezzi, "de modo
} 
intervalar, estendendo as relações entre estes intervalos a outros parâmetros sonoros e musicais, como a duração e a forma ${ }^{221}$, justificando a escolha das tradições musicais escolhidas tanto por seu desenvolvimento como música clássica, antiguidade e simbologia, quanto por sua coincidente concepção metafísica, mesmo que cada tradição possa atribuir significados diferenciados a símbolos aparentemente similares ou significados relativamente idênticos a símbolos diferentes.

Daniélou não busca descobrir como foi o começo desta opção pela divisão discreta do espaço sonoro, como ele afirma

o problema real não é saber como os seres humanos podem ter adquirido o conhecimento dos intervalos musicais, que sempre nos trás de volta à questão do mito, antigo ou moderno, mas encontrar a natureza real do fenômeno pelo qual alguns sons podem ser combinados para representar ideias, imagens ou sentimentos. Isto, obviamente, nós não podemos descobrir pela experiência nem decidir por votação. Então nós teremos de recorrer aos dados da metafísica tradicional; embora ela possa tomar muitas formas em diferentes épocas e em diferentes lugares, a metafísica sempre apresenta a mesma estrutura lógica e coerente, da qual vamos em breve tentar dar um esboço. ${ }^{222}$ (DANIÉLOU, 1995, p. 2)

Os sons seriam combinados em relações específicas porque tais relações seriam

geral, discreto é aquilo que exprime objetos distintos, que se revela por sinais separados, que se põe à parte.

Vem do latim discretus, particípio passado do verbo discernere (discernir), que significa discriminar, separar, distinguir, ver claro. [...] Da mesma fonte derivam as palavras segredo, secreto, certo, discrição. [...] Já contínuo vem de con-tenere (ter junto, manter unido, segurar). Contínuo é o que está imediatamente unido a outra coisa" (BROLEZZI, 1996, p. 1). A essas definições ele acrescenta: "Existem, como sabemos, certas grandezas chamadas contáveis, que são objeto de contagem, como o número de livros em uma prateleira. Outro tipo de grandezas é formado por aquelas quantidades que são passíveis de medida, como a largura desta folha de papel em que escrevo, ou o peso de uma caneta. O primeiro tipo de grandezas é chamado discreto. Grandezas discretas são as que se prestam a contagem. Já o segundo tipo é chamado contínuo, e se refere às medidas" (Ibidem).

No caso da música, o que chamamos de divisão discreta refere-se ao espaço sonoro dividido em alturas definidas. A compreensão de Daniélou deste aspecto discreto na música encontra ressonância na concepção de Boécio e, como nos mostra Burckhardt, “para Boécio, toda ordem formal é uma 'demonstração' da Unidade ontológica. Sua aritmética representa menos um método de cálculo que uma ciência do número.

Aqui o número não é considerado a priori como uma quantidade, mas como uma determinação qualitativa da unidade [...]. O que liga os números entre si é essencialmente a proporção, que é, por sua vez, uma expressão qualitativa da Unidade; quanto ao aspecto quantitativo dos números, este indica apenas seu 'desenvolvimento' material" (BURCKHARDT, 2004, p. 96). Ver também a citação de Cynthia Sampaio de Gusmão à página 190-191 abaixo.

${ }^{221}$ Esta forma de entendimento da relação estendida a outros parâmetros é similar àquela adotada por Karlheinz Stockhausen em sua teoria da Unidade do Tempo Musical (STOCKHAUSEN, 1996. p. 141-9).

${ }^{222}$ The real problem is not to know how human beings may have acquired the knowledge of musical intervals, which always bring us back to a question of myth, ancient or modern, but to find out the real nature of the phenomenon by which some sounds can be combined to represent ideas, images or feelings. This we obviously cannot discover by experiment nor decided by vote. So we shall have to draw upon the data of traditional metaphysics; though it may take many forms at different times and in different places, metaphysics always presents the same logical and coherent structure, of which we shall presently try to give an outline. 
relações existentes em outros domínios inaudíveis, "não obstante, nós podemos ser capazes de produzir sons correspondentes dentro da extensão de vibrações que podemos perceber. Nós podemos estabelecer relações entre estes sons parciais similares às sutis relações da natureza",223 (DANIÉLOU, 1995, p. 4). Nesse sentido, “elas serão apenas relações grosseiras, mas podem aproximar as sutis relações da natureza o suficiente para evocar imagens em nossa mente"224 (Ibidem).

Embora Alain Daniélou trabalhe com a música clássica de três tradições em seu livro Music and the power of sound: a chinesa, a indiana e a grega antiga comparando-as com a atual música ocidental e seu predominante temperamento igual, nos concentraremos aqui em duas dessas tradições de forma a estabelecer as possíveis correspondências metafísicas entre os seus símbolos.

Trabalharemos predominantemente com os paralelismos, coincidências e correspondências metafísicas entre o simbolismo musical de duas tradições musicais: a Indiana e a Grega antiga.

A Indiana por Daniélou ter estudado não apenas o instrumento indiano vīna, mas também sua teoria musical, e a Grega antiga por de certa maneira o ocidente considerar-se herdeiro não só da tradição intelectual grega, mas também de sua música, como nos mostra Rizek ao referir-se a Platão:

Platão, contudo, tem uma importância nas artes e na música, na estética musical e na musicologia. É possível definir os limites de tal importância? Se, por exemplo, atentarmos ao fato de ele ser o principal herdeiro, "coelaborador", transfigurador e divulgador da doutrina dos pitagóricos, sua importância torna-se indiscutível, uma vez que dele recebemos toda uma gama de justificações teórico-matemáticas, prenhe de inferências teológicas, da estrutura diatônica por detrás dos modos gregos, do critério de construção e afinação da escala heptatônica a partir das médias geométrica, aritmética e harmônica dentro da dupla proporção, a oitava ou o diapasôn. Herdamos e incorporamos através dele, para sempre, as razões (em duplo sentido) criteriológicas das consonâncias perfeitas, até hoje designadas como justas: a oitava justa (a média geométrica dentro da dupla oitava), a quinta justa (a média aritmética dentro da oitava) e a quarta justa (a média harmônica dentro da oitava). [...] (RIZEK, 2003, p. 1)

No entanto, utilizaremos quando necessário a simbologia musical chinesa.

Começando já com uma comparação entre a cultura chinesa e a indiana, Daniélou nos

\footnotetext{
${ }^{223}$ we may nonetheless be able to produce corresponding sounds within the range of vibrations we can perceive. We can establish relations between these partial sounds similar to the subtle relations of nature

${ }^{224}$ they will be only gross relations, but they may approach the subtle relations of nature sufficiently to evoke images in our mind
} 
relata que os dois princípios concordantes e complementares, encontrados no clássico chinês $I$ Ching, yang - masculino, positivo, quente, espiritual, ativo; e yin - feminino, negativo, frio, material, passivo;

correspondem ao Sânscrito linga e yoni, que simbolizam Shiva e Shakti, isto é, purusha e prakriti, ser e matéria. Estes dois princípios são a base de toda existência. Qualquer ciência, portanto, deve começar com a definição de suas respectivas posição e proporção no objeto de seu estudo. É com o estudo de sua proporção que o cientista ou o artista deve começar qualquer empreendimento, e isto é particularmente verdadeiro na música, que é a mais direta representação do processo de criação do mundo. ${ }^{225}$ (DANIÉLOU, 1995, p. 31)

Esta representação do processo de criação do mundo, que Daniélou considera como sendo a mais direta a música, tem na vibração um fenômeno secundário, ao contrário do que poderia se imaginar, pois a dificuldade de percepção do som, segundo a metafísica indiana, existe porque

o mundo é composto de cinco elementos, que nós percebemos separadamente por cinco sentidos distintos. O sentido correspondente a cada um destes elementos pode perceber também os elementos mais baixos mas não os mais elevados. Assim a terra, cujo sentido correspondente é o olfato, pode ser percebida por todos os sentidos; água, que corresponde ao sentido do paladar, é percebido por todos os sentidos exceto o olfato; fogo, (identificado com a luz) corresponde à visão e não pode ser provado ou cheirado; o ar, que corresponde ao tato, nem sempre é visível; e finalmente, o éter ${ }^{226}$ pode ser percebido somente por meio do som. Sendo incapazes de verificar nossas percepções auditivas com ajuda de qualquer outro sentido, é impossível para nós justificar as divisões do som como nós o percebemos, porque nós não temos um elemento direto de comparação.

O som sendo uma qualidade do éter, nós podemos visualizá-lo apenas por meio de suas reações sobre outros elementos, tais como ar, por exemplo, cuja qualidade sensível é o tato. Nós, portanto, representamos o som

${ }^{225}$ correspond to the Sanskrit linga and yoni, which symbolize Siva and Śhakti, that is, purusha and prākriti, being and matter. These two principles are the basis of all existence. Any science must therefore begin with the definition of their respective position and proportion in the object of its study. It is with the study of this proportion that the scientist or artist should begin any enterprise, and this is particularly true of music, which is the most direct representation of the process of the world's creation.

${ }^{226}$ Daniélou escreve ether porém entendemos que ele refere-se ao vocábulo inglês aether "o quinto elemento que tudo permeia (por isso quintessência) a partir da qual as outras quatro foram condensadas e para a qual elas podem retornar" [that all-permeating fifth element (hence quintessence) out of which the other four have condensed and into which they may be returned] (GODWIN, 1995, p. 5), que em português se traduz como éter. 
facilmente como uma vibração do ar que, tocando nossos ouvidos, os força a vibrar - um fato que é realmente apenas um fenômeno secundário. ${ }^{227}$ (DANIÉLOU, 1995, p. 62)

Ao considerar a vibração como um elemento secundário, a metafísica indiana citada por Daniélou lembra-nos as ideias do físico Amit Goswami, talvez não por acaso um indiano, que não considera a consciência como um epifenômeno, um elemento secundário e resultante dos processos químicos que ocorrem no cérebro, e sim tais processos como epifenômenos da consciência (cf. GOSWAMI, 2003).

O que temos aqui é uma espécie de inversão em que ao mais sutil se submete o mais grosseiro. Joscelyn Godwin afirma sobre o éter:

Som e éter são assim as primeiríssimas manifestações da consciência objetiva - não as primeiras no tempo, necessariamente, mas as primeiras na hierarquia do ser. Pedras, feitas em grande parte do elemento terra, não poderiam sequer existir se o éter não tivesse congelado até o grau necessário para formá-las. ${ }^{228}$ (GODWIN, 1995, p. 7)

Daniélou aponta que é devido a esse fato que

os teóricos da música indiana afirmam que, embora correspondências sutis entre as leis da natureza e as leis da harmonia, entre os modos musicais e os modos de nossos sentimentos possam ser descobertas experimentalmente, elas podem ser explicadas logicamente e completamente apenas pela metafísica tradicional, cujas fontes estão nos $\operatorname{Vedas}^{229}{ }^{230}$ (DANIÉLOU, 1995, p. 3)

\footnotetext{
${ }^{227}$ The world is composed of five elements, which we perceive separately by five distinct senses. The sense corresponding to each of this elements can also perceive the lower elements but not the higher ones. Thus earth, whose corresponding sense is smell, can be perceived by all senses; water, which corresponds to the sense of taste, is perceived by all senses except smell; fire, (identified with the light) corresponds to sight and cannot be tasted or smelled; air, which corresponds to touch, is no longer visible; and finally, ether can be perceived only through sound. Being unable to verify our hearing perceptions with the help of the any other sense, it is impossible for us to justify the divisions of sound as we perceive them, because we can have no direct element of comparison.

Sound being a quality of ether, we can visualize it only through its reaction upon others elements, such as air, for example, of which the sensible quality is touch. We therefore easily represent sound as a vibration of air that, touching our ears, forces it to vibrate-a fact that is actually only a secondary phenomenon.

${ }^{228}$ Sound and aether are thus the very first manifestations of objective consciousness-not the first in time, necessarily, but the first in the hierarchy of being. Stones, made largely from the element of earth could not even exist if aether had not congealed to the degree necessary to form them.

${ }^{229}$ Denominam-se Vedas os quatro textos, escritos em sânscrito por volta de 1500 a. C., que formam a base do extenso sistema de escrituras sagradas do hinduísmo, que representam a mais antiga literatura de qualquer língua indo-europeia. (Fonte: $<\underline{\mathrm{http}}: / /$ pt.wikipedia.org/wiki/Vedas $>$ )

${ }^{230}$ theorists of Indian music assert that although subtle correspondences can be experimentally discovered between the laws of nature and the laws of harmony, between the modes of music and the modes of our feelings, they can be completely and logically explained only by traditional metaphysics, whose sources is in the Vedas
} 
Segundo os Vedas, e também o Evangelho de João e o Gênesis, o processo de criação se daria quando a "Palavra criadora" é falada, e "se nós formos capazes de reproduzir as exatas relações que constituem os nomes naturais, nós devemos recriar seres, coisas e fenômenos [...] se, entretanto, relações exatas não podem ser produzidas, relações aproximadas tem um poder, se não de criação, ao menos de evocação"231 (DANIÉLOU, 1995, p. 4).

Esta evocação, possível de ser realizada pela música ao aproximar-se das exatas relações que constituem os nomes naturais, na música indiana pode ser atingida pelos ragas, cujos efeitos são explicados por Joscelyn Godwin:

Às vezes um efeito emocional definido é atribuído a ele, mas a associação usual é com as horas ou as estações, por isso os efeitos almejados não dizem respeito a emoções transitórias mas ao alinhamento da psique aos ritmos diários e tempo cósmico. Não há nenhuma emoção particular que alguém normalmente sente ao meio dia, por exemplo, mas o Sol no zênite tem certos efeitos na vida terrena e da mente que o raga serve para complementar. ${ }^{232}$ (GODWIN, 1995, p. 23)

Godwin continua comparando tal atividade musical com um costume monástico ocidental:

Um propósito similar provavelmente está por trás dos cantochões da liturgia católica que são atribuídos aos vários Ofícios ou Horas - os oito serviços ${ }^{233}$ celebrados no curso de cada dia por comunidades monásticas. ${ }^{234}$ (Ibidem)

Este alinhamento da psique com ritmos diários e tempo cósmico proporcionado pelos ragas ou pelo Divino Ofício, aponta para o que Daniélou afirma a respeito da harmonia:

Pela construção artificial da harmonia, nós podemos ir além do fenômeno das vibrações sonoras e perceber não sons, mas relações imateriais por meio das quais podem ser expressas realidades de uma natureza espiritual. Nós

\footnotetext{
${ }^{231}$ If we are able to reproduce the exact relations that constitute the natural names, we should recreate beings, things and phenomena [...] If, however, exact relations cannot be produced, approximate relations have a power, if not the creation, at least of evocation

${ }^{232}$ Sometimes a definite emotional effect is attributed to it, but the usual association is with times or seasons, so that the effects aimed at do not concern the transitory emotions but the alignment of the psyche to diurnal rhythms and to cosmic time. There no particular emotion which one need habitually feel at noon, for instance, but the sun at zenith has certain effects on earthly life and mind which the raga serves to complement.

${ }^{233}$ Trata-se do Ofício Divino: Matinas, Laudas, Prima, Terça, Sexta, Nona, Vésperas e Completas

${ }^{234}$ A similar purpose probably lay behind the plainsong chants of the Catholic liturgy which are ascribed to the various Offices or Hours - the eight services celebrated in the course of each day by monastic communities.
} 
podemos assim levantar o véu pelo qual a matéria esconde de todos nós as verdadeiras realidades. $^{235}$ (DANIÉLOU, 1995, p. 4)

A ideia de que a música pode evocar relações imateriais que vão além das vibrações sonoras é atribuído por Godwin à doutrina das correspondências, uma visão de mundo que foi possível principalmente devido ao fenômeno sonoro da oitava que "é idêntico em padrão, contudo difere em plano",236 (GODWIN, 1992, p. 263).

Tal fenômeno dá origem à questão: “Todos os planos de existência poderiam ser ligados de um modo análogo, cada um refletindo todos os outros, e todos talvez refletindo algum padrão global?"237 (GODWIN, 1992, p. 263-264). Que é respondida pelo próprio Godwin afirmando que "isto é o que a doutrina das correspondências mantém, e há poucas culturas nas quais isto não se encontra numa maior ou menor extensão"238 (GODWIN, 1992, p. 264) e enumera vários exemplos:

O envolvimento mais famoso da música na doutrina das correspondências está na 'Harmonia das Esferas', que interpreta as disposições e movimento dos planetas indicando musicalmente proporções significantes entre elas. Livremente relacionado com isto é a explicação musical dada para a ordem dos dias da semana, e para os doze meses, governados pelos signos do zodíaco $^{239}$. Proporções harmônicas são usadas para exemplificar as diferentes formas de governo, e a série harmônica é aplicada tanto retrospectivamente como profeticamente às épocas históricas. As sete cores do arco-íris e as seis da paleta do pintor, as proporções da arquitetura, e o metro poético são apenas alguns elementos em outras artes cuja 'harmonia' recebeu várias analogias musicais diferentes. Mais recentemente, a música tem sido utilizada como um auxílio no arranjo racional dos elementos químicos, no comportamento de partículas subatômicas e na estrutura da molécula de DNA. O crescimento de plantas e de cristais, as proporções do corpo humano e suas partes, o desenvolvimento do feto e as idades do homem todas foram vistas através da analogia musical. 'Tonalidades' são atribuídas a perfumes, a árvores e cachoeiras, a sólidos e figuras geométricas. Os elementos da alquimia e os aspectos da astrologia são musicalmente relacionados, como são os encantamentos da magia cerimonial a as palavras criativas dos deuses. Estes exemplos devem ser suficientes como um esboço de uma complexa teia de domínios interrelacionados aos quais a música especulativa tem sido aplicada como uma chave. $^{240}$ (GODWIN, 1992, p. 264)

\footnotetext{
${ }^{235}$ By the artificial construction of harmony we can go beyond the phenomenon of sound vibrations and perceive not sounds but immaterial relations through which can be expressed realities of a spiritual nature. We can thus lift the veil by which matter hides from us all true realities.

${ }^{236}$ is identical in pattern, yet differs in plane

${ }^{237}$ Could all the planes of existence be linked in an analogous way, each one reflecting all the others, and all perhaps reflecting some over-arching pattern

${ }^{238}$ this is what the doctrine of correspondences maintains, and there are few cultures in which one does not find it to a greater or lesser extent.

${ }^{239}$ Sobre a simbologia dos números $7(=3+4)$ e $12(=3 \times 4)$ ver p. 45.

${ }^{240}$ Music's most famous involvement in the doctrine of correspondences is in the 'Harmony of Spheres', which
} 
É interessante notar que mesmo estudiosos do simbolismo muitas vezes questionam determinados significados ou correspondências. Roger Cotte, autor do livro Música e simbolismo: ressonâncias cósmicas dos instrumentos e das obras, no caso específico da harmonia das esferas ou música das esferas, nos alerta que a lenda refere-se às proporções sonoras que Pitágoras teria ouvido casualmente ao passar em frente a uma oficina de ferreiro. Estas foram atribuídas às diferenças de tamanho entre os martelos, porém, o padre Marin Mersenne (1588-1648), “em 1634, demonstrou sua inanidade” (COTTE, 1991, p. 12) pois a diferença entre os tamanhos dos martelos não influenciaria na diferença sonora, apenas o tamanho da bigorna onde se bateriam tais martelos.

Acrescenta também que

de acordo com outra explicação, teria havido confusão entre os vocábulos

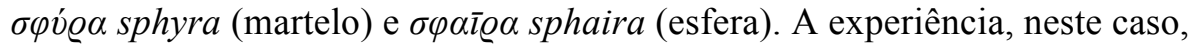
teria sido feita com esferas ocas de volumes diferentes, o que, acusticamente, seria perfeitamente concebível. Além disso, o termo "música das esferas" se explicaria então de maneira prática, sem alusão cósmica prematura. (COTTE, 1991, p. 12)

Apesar de tais argumentos e discussões sobre a validade da música das esferas e sua aparente instância prática, a ligação da tradição pitagórica com a nascente filosofia, gerou e desenvolveu todo um arcabouço teórico para a música especulativa em relação com a matemática e a filosofia, de forma que Ricardo Rizek afirma:

Pela articulação hierárquica de alguns poucos elos, uma matematizada teoria musical de origem pitagórica unia-se à filosofia já no seu nascedouro platônico, e tal união manter-se-ia inquestionável por dois milênios. Embora exclusivamente como musica theoretica ${ }^{241}$, ou seja, como ciência cosmológica partícipe da filosofia especulativa (a parte da filosofia

interprets the dispositions and movements of the planets by indicating musically significant proportions between them. Loosely related to this is the musical explanation given for the order of days of the week, and for the twelve months, governed by the signs of the zodiac. Harmonic proportions have also been used to exemplify the different forms of government, and the harmonic series has been applied both retrospectively and prophetically to historical epoch. The seven colour of the rainbow and the six of the of the painter's palette, the proportions of architecture, and poetic metre are just a few elements in the other arts whose 'harmony' has received several different musical analogies. More recently, music has been used as an aid to the rational arrangement of the chemical elements, the behaviour of subatomic particles, and the structure of the DNA molecule. The growth of plants and of crystals, the proportions of the human body and its parts, the development of the foetus and the ages of man have all been viewed through the musical analogy. 'Keynotes' have been assigned to perfumes, to trees and waterfalls, to geometrical figures and solids. The elements of alchemy and the aspects of astrology are musically related, as are the incantations of ceremonial magic and the creative words of the gods. These examples must suffice as a sketch of the complex web of interrelated domains to which speculative music has been applied as a key.

${ }^{241} \mathrm{O}$ que abordamos no subcapítulo anterior como Música Especulativa. 
destinada à compreensão da phýsis), tal disciplina estava longe de não ter profundas implicações estéticas. Para além das [...] proporções e mediações verdadeiramente fundamentando um sistema modal, isto é, a organização sistêmico-diatônica dos modos gregos; para além de tais proporções e mediações matemáticas fundamentarem cosmogonicamente as consonâncias sobre as quais se assentaria toda a prática musical, desde a Antiguidade até o contraponto da ars nova na passagem do século XIII para o XIV, tais razões, proporções e harmonias desveladas matematicamente por esta theoría musical reverberava e ainda reverbera ("apolineamente", em linguagem nietzscheana) em todas as demais artes, especialmente na escultura, arquitetura e pintura. (RIZEK, 2003, p. 2-3)

Antes de encerrarmos este subcapítulo cabe aqui uma pequena digressão a respeito do aspecto qualitativo do número. Na página 131 mostramos como Lawlor interpreta a expansão quantitativa dos números, ao acrescentar-se o zero, e como se dá com sua ausência a expansão qualitativa. Veremos aqui como ele define os aspectos qualitativos dos números 1 ao 4 , mesmo que possam definir quantidades.

O número UM representa o princípio da unidade absoluta, é utilizado como símbolo de Deus. Sua manifestação formal é a de um ponto ou de um círculo perfeito.

O número DOIS por sua vez, representa o princípio da dualidade, o poder da multiplicidade. Formalmente é representado por uma linha que une dois pontos.

Já o número TRÊS representa a trindade, um conceito vital. Sua forma é a do triângulo e é responsável pela transição da abstrações da linha e do ponto para o estado tangível da superfície ou plano. Na Índia era chamado de Mãe, pois por ele deve passar os poderes transcendentes da unidade e da dualidade polarizada para o reino manifesto da superfície. É um princípio de criação responsável pela passagem do transcendente ao manifesto.

Finalmente, o número QUATRO representa o mundo da natureza, é o produto do processo procriador, da multiplicação $2 \times 2=4$. Formalmente é o quadrado e representa a materialização (LAWLOR, 1996, p. 12). 


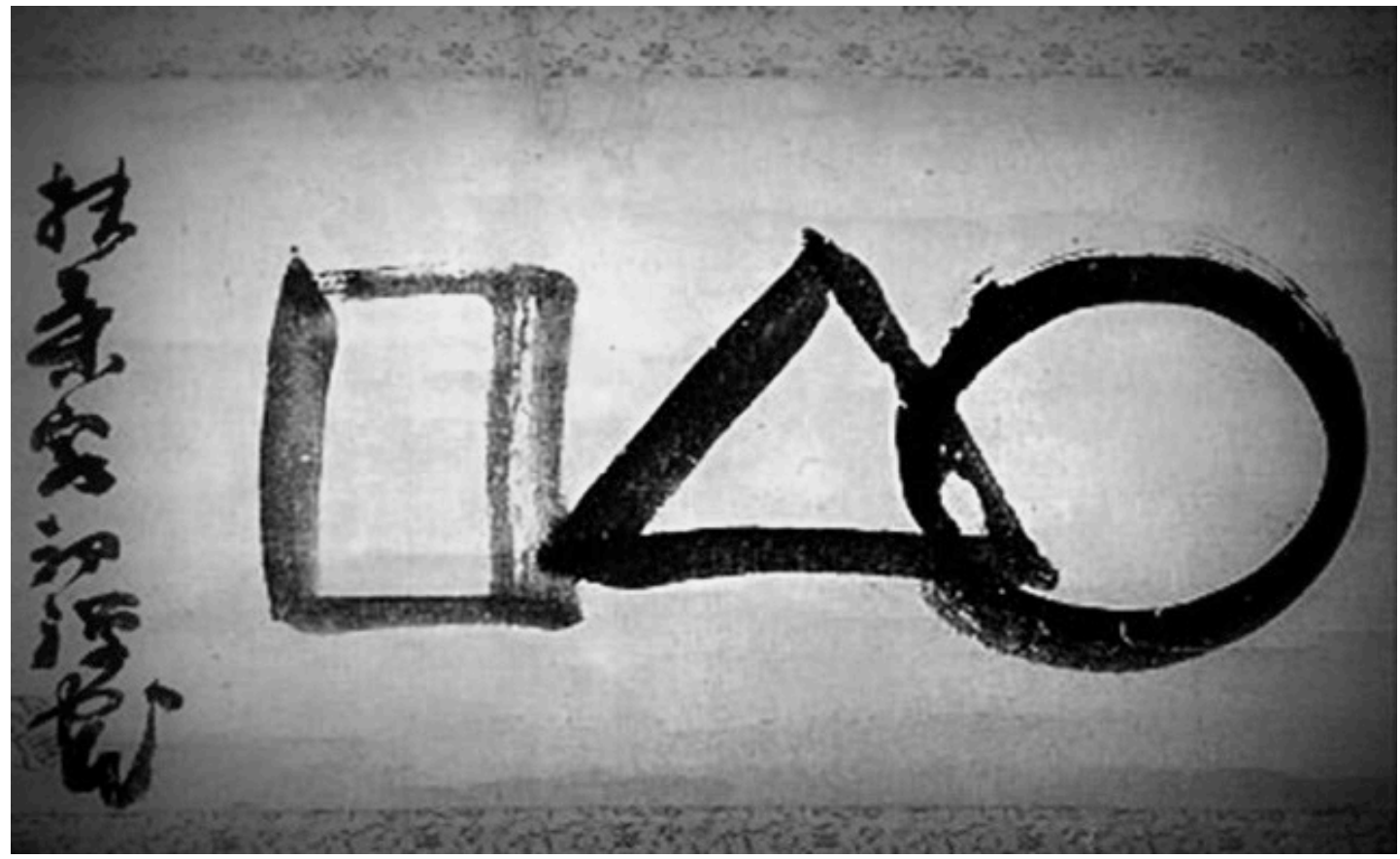

Figura 2: Desenho caligráfico zen japonês representa harmoniosamente a "criação" mediante a progressão da unidade do círculo, passando pelo triângulo, até a forma manifesta do quadrado (LAWLOR, 1996, p. 13). ${ }^{242}$

Estes números de 1 a 4 formam a tetraktys pitagórica cuja soma é igual a 10 e representa o número perfeito, e sua representação gráfica é similar a um triângulo:

Segundo Sylvia Leite (2007, p. 77), "vemos a unidade no alto, a dualidade na segunda linha, a tríade na terceira e a tétrada na quarta e última linha. Igual leitura pode ser feita a partir de qualquer uma das pontas do triângulo".

\footnotetext{
${ }^{242}$ Desenho atribuído a Sengai Gibon (1750-1837) monge da escola Rinzai. Fonte: $<$ http://shineitaido.blogspot.com.br/2013/01/o-universo-e-mestre-sengai.html>
} 


\section{1 \\ 23 \\ $\begin{array}{llll}4 & 5 & 6\end{array}$ \\ $\begin{array}{llll}7 & 8 & 9 & 10\end{array}$}

Utilizando a tetraktys como sequência numérica, encontramos os números 5,6 e 7 somando cada linha, de forma que $2+3=5,4+5+6=15(1+5=6)$ e $7+8+9+10=34$ $(3+4=7)$.

O número cinco, que na maioria das tradições é relacionado ao homem, ocupa uma posição central. Desse ponto de vista, o cinco assume a condição de pólo, da mesma forma que o homem, por ter sido provido ao mesmo tempo de materialidade e espiritualidade, é considerado intermediário entre a Divindade e as coisas materiais. (LEITE, 2007, p. 77-78)

Lembramos aqui que Daniélou atribui à nossa percepção auditiva o funcionamento em três linguagens: binária, representada pelo número 2 e responsável pelo espaço, se lembrarmos que 4 é o dobro de 2, e portanto podemos considerá-lo como oitava, vemos aí uma correspondência com a forma geométrica proposta acima por Lawlor representada pelo quadrado; ternária, representada pelo número 3 e associada ao movimento, atividade e motor, representa musicalmente a quinta justa, é responsável pela transição do transcendente ao manifesto, o triângulo segundo Lawlor; e por fim a linguagem quinária, representada pelo número 5, que "humaniza a música. Ele faz da música o instrumento de expressão não de

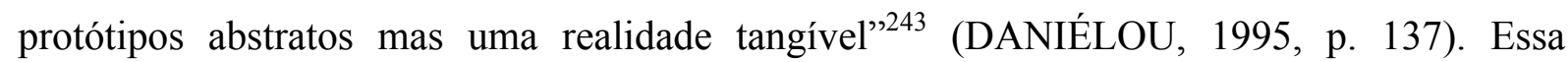
linguagem quinária, associada ao intervalo de terça, é responsável pela expressão de sentimento, sensação e emoção, característica tipicamente humana e seu paralelo visual é o pentágono, associado ao crescimento e à vida bem como ao número áureo, o que coincide com o que nos mostra Sylvia Leite ao comentar o número cinco no centro da tetraktys.

Quanto à simbologia do número 7, Sylvia Leite o relaciona à educação clássica dividida entre as três artes do Trivium e as quatro disciplinas do Quadrivium:

o Trivium, de caráter ontológico e descendente, que reunia a Gramática, a Lógica e a Retórica, e o Quadrivium, de caráter cosmológico e ascendente,

\footnotetext{
${ }^{243}$ humanizes music. It makes music the instrument of expression no longer of abstract prototypes but a tangible reality.
} 
que compreendia a Aritmética, a Astrologia, a Geometria e a Música. O Trivium expressaria, assim, a linguagem da distinção ou revelação, veiculada originariamente pelo livro sagrado, e o Quadrivium expressaria a linguagem da unificação por meio da qual o homem pode atingir a iluminação, veiculada pela música, pelos números, pelos planetas e pelos padrões geométricos. (LEITE, 2007, p. 79)

No entanto, Daniélou considera que "sete é o número dos mundos celestes bem como das regiões infernais, e nós geralmente não temos meios de saber para qual lado ele pode nos levar"244 (DANIÉLOU, 1995, p. 137). Além disso, com relação aos intervalos que contém este elemento, "seu efeito mágico também está normalmente além de nosso controle, consequentemente, seu uso em música e sua teoria não nos serve para nenhum propósito útil",245 (Ibidem).

\subsection{Matemática: a Escala Universal dos Sons e sua relação com a série harmônica}

O autor deste artigo é da opinião que... o mesmo som não pode mais representar corretamente $\mathrm{C} \# \mathrm{e} \mathrm{D}$, , assim como o número 62 não pode representar corretamente os dois produtos de $6 \times 10$ e de $8 \times 8$. $^{246}$

H. W. Poole, An Essay on Perfect Musical Intonation in the Organ (1850)

(apud DUFFIN, 2007, p. 94)

Alain Daniélou elabora em sua obra uma escala para que se possa entender e estudar melhor as músicas clássicas das culturas que ele pesquisa em seus livros Music and the Power of Sound (1995) - que já se chamou Traité de Musicologie Comparée (2004) - e Sémantique Musicale (1993). Ele denomina a escala com diferentes nomes: Escala dos Sons (DANIÉLOU, 1995, p. 135; 2004, p. 165), Escala de Intervalos (DANIÉLOU, 1993, p. 82) ou ainda Escala Universal dos Sons (DANIÉLOU, 1995, p. 142; 2004, p. 166).

Ele justifica a necessidade desta escala afirmando que

para o estudo comparativo de diferentes sistemas musicais, bem como para a

\footnotetext{
${ }^{244}$ Seven is the number of the heavenly worlds as well as that of the infernal regions, and we usually have no means of knowing to which side it may lead us

${ }^{245}$ their magical effect too is normally beyond our control. consequently, their use in music and its theory serves no useful purpose

${ }^{246}$ The writer of this paper is of the opinion that... the same sound can no more correctly represent $C \#$ and $D$, than the number 62 can correctly represent the two products of 6 into 10, and 8 into 8.
} 
execução correta de cada um, é necessário estabelecer uma escala de sons que permitirá tanto uma notação clara e precisa de todos os intervalos usuais quanto uma apreciação imediata de sua natureza e valor relativo. Com a ajuda de uma notação precisa, a reprodução das diferentes escalas em um instrumento apropriado torna-se fácil. ${ }^{247}$ (DANIÉLOU, 1995, p. 135)

O filósofo Giovanni Piana, sugere que esta escala serviria como uma espécie "régua graduada" - pois divide a oitava em 53 partes, com intervalos naturais e não temperados - de forma que "uma escala será considerada 'natural' se todos os seus intervalos coincidirem com algumas das 53 partes da "escala harmônica",248 (PIANA, 2003, p. 23 grifos do autor ). Com isso a escala de Daniélou permitiria analisar as características comuns às escalas de culturas musicais diversas.

Em seus dois livros que tratam desta escala, Daniélou descreve, de maneira bastante complexa, uma emaranhada sequência de cálculos intervalares para obtê-la. Descreveremos logo mais este processo proposto por Alain Daniélou.

Como vimos acima, no subcapítulo 2.3. Semântica Musical da Parte 1, Daniélou entende que os efeitos psicofisiológicos da música devem-se à percepção de nosso aparelho áudio-mental, que analisa as informações sonoras a partir da percepção do tímpano que, por ser uma membrana similar a de um tambor, receberia esta informação como pressões e depressões que seriam traduzidas em três linguagens numéricas: binária, ternária e quinária.

Esta forma de interpretar a informação sonoro-musical assemelha-se a duas maneiras com que Leibniz entende a percepção e a relação entre teoria e prática musicais.

A primeira tem a ver com a percepção, com a interpretação da informação que chega ao ouvido, uma vez que, como afirma Leibniz, "nosso espírito procura o comensurável mesmo no mais simples, e ele o encontra na música, sem que aqueles que o ignoram se apercebam disso" (LEIBNIZ, 2007, p. 110).

Já a segunda tem a ver com a questão teórica em relação com a prática, pois segundo Juvenal Savian Filho, Leibniz

[...] se mantém em continuidade com uma antiga tradição que remonta aos pitagóricos e se fortalece no período medieval, mantendo-se viva, ainda, no período renascentista. Ao mesmo tempo, rompe com ela, porque não trata $o$ teórico como sendo o 'verdadeiro músico', nem a música ouvida como não

\footnotetext{
${ }^{247}$ For the comparative study of different musical systems, as well as for correct execution of each one, it is necessary to establish a scale of sounds that will allow both a clear and accurate notation of all the usual intervals and an immediate appreciation of their nature and relative value. With the help of an accurate notation, the reproduction of the different scales on an appropriate instrument becomes easy.

${ }^{248}$ regoli graduati [...] Una scala sarà da considerarsi "naturale" se tutti $i$ suoi intervalli coincidono con alcune delle 53 lineette della "scala armonica".
} 
participante da verdade teórica. Ao contrário, embora afirme a teoria como imprescindível, chega a admitir que o compositor pode até mesmo ignorar a teoria musical. O que vale notar é que, para Leibniz, o fenômeno musical remete diretamente à experiência musical do ouvinte e do compositor, e o prazer causado não é apenas teórico, inteligível (pelo menos não imediatamente), mas físico, confuso, porque há pequenas percepções graças às quais nasce no espírito a sensação de prazer produzida por causas invisíveis ou aparentemente insensíveis. (SAVIAN FILHO, 2007, p. 106)

Desse modo, a escala dos sons elaborada por Daniélou aborda estas duas vertentes: a teórica e a perceptiva. Ele afirma mais precisamente:

Para nossa investigação, os intervalos musicais aparecem sob dois aspectos: um matemático, envolvendo números e proporções lógicas; outro simbólico e psicológico, em que as relações sonoras (sua harmonia) despertam em nós sentimentos, ideias e visões precisas. Seus dois aspectos têm, obviamente, sua origem nos mesmos princípios, mas esta unidade está além do escopo do experimento e consequentemente além da compreensão dos ocidentais modernos. Esta deficiência naturalmente os leva para a situação ilógica de deixar de lado um aspecto da experiência sempre que eles estudam o outro, como se as leis da acústica e aquelas da expressão musical não se referissem aos mesmos sons. ${ }^{249}$ (DANIÉLOU, 1995, p. 13)

Tal escala deveria, portanto, servir como um modelo que consiga explicar ao mesmo tempo diversas elaborações escalares vindas de culturas musicais diferentes, e que possa também explicar os efeitos psicofisiológicos característicos da audição musical. Mais uma vez o aproximamos de Leibniz, que afirma em seu texto Principes de la nature et de la grace fondés em raison:

a música nos encanta, embora sua beleza não consista senão nas conveniências dos números e no cálculo - do qual não nos apercebemos, mas que a alma não nos deixa de fazer - das batidas ou das vibrações dos corpos sonantes, que se relacionam por certos intervalos. ${ }^{250}$ (LEIBNIZ apud SAVIAN FILHO, 2007, p. 105)

A partir de dois sistemas, por ciclo (escala de quintas) e por múltiplos (escala por

\footnotetext{
${ }^{249}$ For our investigation, musical intervals appear under two aspects: one mathematical, involving numbers and logical ratios; the other symbolic and psychological, in which the relations of sounds (their harmony) awaken in us feelings, ideas, and precise visions. Their two aspects obviously have their origin in the same principles, but this unity is beyond the scope of experiment and consequently beyond the understanding of modern Westerners. This deficiency naturally brings them to the illogical situation of leaving aside one aspect of experience whenever they study the other, as if the laws of acoustics and those of musical expression did not refer to the same sounds.

${ }^{250} \mathrm{Na}$ tradução portuguesa: "Encanta-nos a música e, no entanto, a sua beleza consiste tão-só nas conformidades entre números e no cômputo, de que não nos apercebemos e que a alma não deixa de fazer, dos batimentos ou vibrações dos corpos soantes que se conjugam por certos intervalos" (LEIBNIZ, s.d., p. 12, § 17).
} 
harmônicos), os quais Daniélou atribui ao sistema chinês e ao sistema indiano respectivamente, ele desenvolve sua escala para possíveis interpretações teóricas. Quanto à música grega, ele a interpreta como uma "confusão dos sistemas" (DANIÉLOU, 2004 e 1995), em que descrições de diversos teóricos tais como Pitágoras, Aristóteles, Boécio, Aristides Quintiliano, entre outros, tornam difícil generalizar um sistema único e homogêneo.

Quanto ao sistema ocidental, achamos oportuno citar aqui literalmente o que já referimos como paráfrase acima [cf. p. 59-60] no subcapítulo 2.2. Música e o Poder do Som (Tratado de Musicologia Comparada).

Daniélou afirma:

O sistema musical ocidental emergiu de uma mistura de várias tradições que, devido a uma confusão completa nas definições teóricas, foram reunidas de uma maneira bastante caótica. O sistema resultante é cíclico, com constante mudanças de tônica (modulações), mas sobre cada tônica, e sobre cada nota das escalas baseadas nestas tônicas, o estabelecimento de acordes (harmonia) depende do sistema modal, já que as diferentes notas tomam seu significado de sua relação com a nota fundamental do acorde. Este sistema teria tido toda vantagem se não tivesse sido baseado em uma confusão fundamental: as notas que formam os acorde consonantes não são as mesmas notas requeridas para modulação. ${ }^{251}$ (DANIÉLOU, 1995, p. 121)

Como já vimos acima no subcapítulo 2.3. Semântica Musical, para Daniélou o número 2, responsável pelo intervalo de oitava, representa a dimensão do espaço ou do tempo, uma espécie de moldura, de caráter estático; já o número 3, que equivale ao intervalo de quinta justa, representa movimento, atividade, enquanto o número 5 , equivalente ao intervalo de terça, representa a emoção e a sensação (DANIÉLOU, 1993, p. 63), “o número cinco 'humaniza' a música” (Idem, 1995, p. 137).

Considerando o número 12 como resultante da multiplicação dos números 3 e 4 (3 × 4 = 12) Daniélou concebe o conjunto das notas musicais como uma área dividida em doze regiões, estas doze regiões não seriam identificadas como doze alturas absolutas. Assim, de acordo com suas relações intervalares, cada nota pode ter diferentes alturas, mesmo conservando os mesmos nomes. Daniélou utiliza em seus livros diversas tabelas e gráficos, além da descrição textual do processo para se obter os intervalos exatos para sua escala, que

${ }^{251}$ The Western musical system has emerged from a mixture of various traditions that, because of complete confusion in the theoretical definitions, were brought together in a rather haphazard way. The resulting system is cyclic, with constant changes of tonic (modulations), but on each tonic, and on each note of the scales based on these tonics, the establishments of chords (harmony) depends upon the modal system, since the different notes of a chord take their meaning from their relation to the fundamental note of the chord. This system would have had every advantage had it not been based upon a fundamental confusion: the notes that form consonant chords are not the same as the notes required for modulation. 
veremos a seguir.

A partir da nota Dó eleita como tônica, cuja razão é $1 / 1$ (ou 1), somam-se intervalos que possuam o número 3 no numerador (quinta ascendente) ou no denominador (quinta descendente) formando a Série de Base. Lembrando que a soma de frações, que neste caso referem-se aos intervalos musicais e que portanto possuem uma característica logarítmica, se consegue multiplicando seus termos.

Deste modo, quando acrescentamos um intervalo de quinta ascendente à nota Dó (1) temos a seguinte operação: $1 / 1 \times 3 / 2=3 / 2$; em seguida multiplicamos este resultado por uma nova quinta: $3 / 2 \times 3 / 2=9 / 4$ que para mantê-la dentro da mesma oitava, ou seja, entre 1 e 2 (Dó e sua oitava superior) devemos dividi-la por 2 , daí temos: $9 / 4 \div 2=9 / 4 \times 1 / 2=9 / 8$; adicionamos mais uma quinta e temos: $9 / 8 \times 3 / 2=27 / 16$; a esta uma nova quinta é adicionada: $27 / 16 \times 3 / 2=$ ${ }^{81} / 32$, este resultado deve ser dividido por dois para permanecer na mesma oitava, como fizemos com o $9 / 8$ o que resulta em: ${ }^{81} / 32 \div 2={ }^{81} / 32 \times 1 / 2={ }^{81} / 64$; finalmente a última quinta acrescentada e temos: ${ }^{81} / 64 \times 3 / 2=243 / 128$. Temos então cinco quintas ascendentes: ${ }^{3} / 2,9 / 8,{ }^{27} / 16$, $81 / 64 \mathrm{e}^{243} / 128$.

Repetindo este processo com as quintas descendentes temos: para acrescentar uma quinta descendente ao Dó (1) temos a seguinte operação: $1 / 1 \times 2 / 3=2 / 3$, que para mantê-la dentro da mesma oitava, ou seja, entre 1 e 2 (Dó e sua oitava superior) devemos multiplicá-la por 2 , daí temos: $2 / 3 \times 2 / 1=4 / 3$; em seguida multiplicamos este resultado por uma nova quinta descendente: $4 / 3 \times 2 / 3=8 / 9$ que para mantê-la dentro da mesma oitava, ou seja, entre 1 e 2 (Dó e sua oitava superior) devemos também multiplicá-la por 2, daí temos: $8 / 9 \times 2 / 1=16 / 9$; adicionamos mais uma quinta e temos: $16 / 9 \times \frac{2}{3}=32 / 27$; a esta uma nova quinta é adicionada: $32 / 27 \times 2 / 3=64 / 81$, este resultado deve ser multiplicado por dois para permanecer na mesma oitava, como fizemos com o $4 / 3$ e o $16 / 9$ que resulta em: ${ }^{64} / 81 \times 2 / 1=128 / 81$; finalmente a última quinta descendente acrescentada e temos: $128 / 81 \times \frac{2}{3}=256 / 243$. Temos então cinco quintas descendentes: ${ }^{4} / 3,16 / 9,32 / 27,128 / 81 \mathrm{e}^{256} / 243$.

A partir de Dó se estabelece a nota Lá que será à base da Série -, utilizando o número 5 no numerador, $1 / 1 \times 5 / 3=5 / 3\left(6^{\mathrm{a}} \mathrm{M}\right.$ ascendente $)$, acrescentando quatro quintas ascendentes, ou seja multiplicando consecutivamente por $3 / 2$ temos: $5 / 3 \times 3 / 2=15 / 6$, que devemos dividir por dois para que possa permanecer na mesma oitava, como nos processos anteriores: $15 / 6 \div 2=$ $15 / 6 \times 1 / 2=15 / 12$, simplificando este valor dividindo os dois termos por três temos: $15 / 12 \div 3 / 3=$ $5 / 4$; a partir daí acrescentamos mais três quintas ascendentes e temos as seguintes razões: $5 / 4$, $15 / 8,45 / 32 \mathrm{e}^{135 / 128}$

A esta mesma nota Lá acrescentamos quatro quintas descendentes multiplicando 
consecutivamente por $2 / 3$ temos: $5 / 3 \times 2 / 3=10 / 9$, fazendo isso sucessivamente acrescentando mais três quintas temos as seguintes razões: $10 / 9,40 / 27,160 / 81 \mathrm{e}^{320} / 243$.

Usando o mesmo processo, utilizando o número 5 como denominador, a partir de Dó temos a nota $\mathrm{Mi} b+$, base da Série,$+ 6 / 5$ ( $3^{\mathrm{a}} \mathrm{m}$ ascendente), somam-se quatro quintas ascendentes: ${ }^{9} / 5,{ }^{27} / 20,{ }^{81} / 80 \mathrm{e}^{243} / 160$; e quatro quintas descendentes: ${ }^{8} / 5,16 / 15,64 / 45 \mathrm{e}^{256 / 135}$.

Daniélou segue o mesmo processo chegando à nota Fá\#++ $(36 / 25)$, base da Série ++ e à nota Fá\#- $(25 / 18)$, base da Série - . A cada uma delas soma-se 4 quintas ascendentes e quatro descendentes ${ }^{252}$.

Na Tabela 6 abaixo, em ordem crescente, a sequência das 53 notas, e suas respectivas razões, da Escala Universal dos Sons de Daniélou com a nomenclatura anglo-saxônica e indiana. Ele ainda acrescenta 12 quartos de tom (não numerados) e temos então 66 notas (contando com a oitava de Dó):

\begin{tabular}{|c|c|c|c|c|c|c|c|c|c|c|c|c|c|c|}
\hline & Nota & Razão & & Nota & Razão & & Nota & Razão & & Nota & Razão & & Nota & Razão \\
\hline 1 & $C(\mathrm{Sa})$ & $1 / 1$ & & $1 / 4$ & $93 / 80$ & 23 & $F(M a)$ & $4 / 3$ & 34 & $\mathrm{G}++$ & $192 / 125$ & 44 & $A \#^{L-}$ & $225 / 128$ \\
\hline 2 & $\mathrm{C}+$ & $81 / 80$ & 13 & $\mathrm{D} \#$ & $75 / 64$ & 24 & $\mathrm{~F}+$ & $27 / 20$ & & $1 / 4$ & $31 / 20$ & 45 & $\mathrm{~B},{ }^{\mathrm{L}+}$ & $16 / 9$ \\
\hline \multirow[t]{2}{*}{3} & $\mathrm{C}++$ & $128 / 125$ & 14 & $\mathrm{D} \#^{\mathrm{L}}$ & $32 / 27$ & 25 & $\mathrm{~F}++$ & $512 / 375$ & 35 & $\mathrm{G}_{\#}$ & $25 / 16$ & 46 & $\mathrm{~B}$, & $9 / 5$ \\
\hline & $1 / 4$ & $(30 / 31)$ & 15 & $\mathrm{E} b$ & $6 / 5$ & & $1 / 4$ & $62 / 45$ & 36 & $\mathrm{G} \#^{\mathrm{L}}$ & $128 / 81$ & & $3 / 4$ & $29 / 16$ \\
\hline 4 & $\mathrm{C} \sharp$ & $25 / 24$ & & $3 / 4$ & $75 / 62$ & 26 & $\mathrm{~F} \#$ & $25 / 18$ & 37 & A, & $8 / 5$ & 47 & $\mathrm{~B}-$ & $4000 / 2187$ \\
\hline 5 & $\mathrm{C} \#{ }^{\mathrm{L}-}$ & $256 / 243$ & 16 & $\mathrm{E}-$ & $8000 / 6561$ & 27 & $\mathrm{~F} \sharp^{\mathrm{L}-}$ & $45 / 32$ & & $3 / 4$ & $50 / 31$ & 48 & $\mathrm{~B}-$ & $50 / 27$ \\
\hline 6 & $\mathrm{D}_{b}{ }^{\mathrm{L}^{+}}$ & $16 / 15$ & 17 & $\mathrm{E}-$ & $100 / 81$ & 28 & $\mathrm{G} b^{\mathrm{L}+}$ & $64 / 45$ & 38 & $\mathrm{~A}-$ & $81 / 50$ & 49 & B (Ni) & $15 / 8$ \\
\hline \multirow[t]{2}{*}{7} & $\mathrm{D}$ & $27 / 25$ & 18 & $\mathrm{E}(\mathrm{Ga})$ & $5 / 4$ & 29 & $\mathrm{G}$ & $36 / 25$ & 39 & A - & $400 / 243$ & 50 & $B+$ & $243 / 128$ \\
\hline & $3 / 4$ & $135 / 124$ & 19 & $E+$ & $81 / 64$ & & $3 / 4$ & $90 / 62$ & 40 & A (Dha) & $5 / 3$ & 51 & $\mathrm{~B}++$ & $48 / 25$ \\
\hline 8 & $\mathrm{D}-$ & $800 / 729$ & 20 & $\mathrm{E}++$ & $32 / 25$ & 30 & $\mathrm{G}-$ & $375 / 256$ & 41 & $A+$ & $27 / 16$ & & $1 / 4$ & $60 / 31$ \\
\hline 9 & $\mathrm{D}-$ & $10 / 9$ & & $1 / 4$ & $31 / 24$ & 31 & $\mathrm{G}-$ & $40 / 27$ & 42 & $\mathrm{~A}++$ & $128 / 75$ & 52 & $\mathrm{C}-$ & $125 / 64$ \\
\hline 10 & $D(R e)$ & $9 / 8$ & 21 & $\mathrm{~F}-$ & $125 / 96$ & 32 & $G(P a)$ & $3 / 2$ & & $1 / 4$ & $31 / 18$ & 53 & $\mathrm{C}-$ & $160 / 81$ \\
\hline 11 & $\mathrm{D}+$ & $256 / 225$ & 22 & $\mathrm{~F}-$ & $320 / 243$ & 33 & $\mathrm{G}+$ & $243 / 160$ & 43 & $\mathrm{~A} \#$ & $125 / 72$ & 54 & $C(\mathrm{Sa})$ & 2 \\
\hline 12 & $\mathrm{D}++$ & $125 / 108$ & & & & & & & & & & & & \\
\hline
\end{tabular}

Tabela 6: Escala Universal dos Sons de Alain Daniélou com suas subdivisões, notas e razões. Em sombreado as notas da escala Justa, em negrito e itálico as notas da escala Pitagórica. Dó, Ré, Fá e Sol pertencem às duas escalas. As notas da escala Pitagórica são ligeiramente mais agudas

O filósofo italiano Giovanni Piana, no artigo La scala universale dei suoni di Daniélou, fazendo uma redução de todos estes cálculos de Daniélou a uma elegante fórmula

\footnotetext{
${ }^{252}$ Curiosamente, e sem justificativa, Daniélou opta por Fáł++ ao invés de Solb++, que seria a $3^{\mathrm{a}}$ menor de Mi $b+$.
} 
matemática $^{253}$. Descrevemos de maneira básica os procedimentos para sua elaboração (PIANA, 2003, p. 43 a 45):

1 - A Série de Base é gerada por $(3 / 2)^{\mathrm{y}}$, onde $y$ varia entre $-5 \mathrm{e}+5$. Um número com expoente zero é igual a 1 , portanto com $y=0$ temos o primeiro elemento da série ${ }^{254}$, o Dó. Se $y$ variar entre $-5 \mathrm{e}+5$ temos respectivamente cinco quintas descendentes e cinco ascendentes.

2 - A fórmula $(6 / 5)^{\mathrm{x}} \times\left(\frac{3}{2}\right)^{\mathrm{y}}$ gera as Séries -, — e — - onde $x$ varia entre 1 e 3 . O valor inicial se dá com $y=0$. Se $y$ variar entre $-4 \mathrm{e}+4$ temos respectivamente quatro quintas descendentes e quatro ascendentes a partir do intervalo inicial de $3^{\mathrm{a}} \mathrm{m}(6 / 5)$.

3 - A fórmula $\left(\frac{5}{3}\right)^{\mathrm{x}} \times\left(\frac{3}{2}\right)^{\mathrm{y}}$ gera as Séries,$+++\mathrm{e}+++$, onde $x$ varia entre 1 e $3 . \mathrm{O}$ valor inicial se dá com $y=0$, e com $y$ variando entre $-4 \mathrm{e}+4$ temos respectivamente quatro quintas descendentes e quatro ascendentes a partir do intervalo inicial de $6 \mathrm{a}\left(\frac{5}{3}\right)$.

4 - Reduzindo as três fórmulas acima em uma: a segunda fórmula se reduz à primeira quando $x=0$. A razão $6 / 5$ invertida e multiplicada por 2 é igual a $5 / 3$, portanto, se acrescentarmos uma variável $z=2$, apenas quando $\mathrm{x}$ for negativo, obteremos a série que se forma a partir de $5 / 3$. Temos então a seguinte fórmula: $(6 / 5)^{\mathrm{x}} \times\left({ }^{3} / 2\right)^{\mathrm{y}} \times \mathrm{z}$, que substitui as três anteriores, onde $x$ varia entre $-3 \mathrm{e}+3, y$ entre $-4 \mathrm{e}+4$ (entre $-5 \mathrm{e}+5$ caso se queira 5 quintas) e $z$ entre 1 e 2 com a condição: se $x$ positivo ou igual a 0 , então $z=1$, se $x$ negativo, então $z=2$.

Temos então: $x$ negativo representa as séries “-”, $x$ positivo as séries “+”, e $x=0$ a série fundamental; $y$ negativo representa quintas descendentes, $y$ positivo quintas ascendentes e $y=0$ o primeiro elemento de cada série. Os intervalos obtidos devem ser colocados dentro de uma oitava e ordenados de forma crescente.

5 - Esta fórmula ainda pode ser transformada e simplificada algebricamente da seguinte maneira:

$$
\begin{aligned}
& (6 / 5)^{\mathrm{x}} \times\left({ }^{3} / 2\right)^{\mathrm{y}} \times \mathrm{z}= \\
& (2 \times 3 \times 1 / 5)^{\mathrm{x}} \times(3 \times 1 / 2)^{\mathrm{y}} \times \mathrm{z}= \\
& 2^{\mathrm{x}} \times 3^{\mathrm{x}} \times\left({ }^{1} / 5\right)^{\mathrm{x}} \times 3^{\mathrm{y}} \times(1 / 2)^{\mathrm{y}} \times \mathrm{z}= \\
& 2^{\mathrm{x}} \times 3^{\mathrm{x}} \times 5^{-\mathrm{x}} \times 3^{\mathrm{y}} \times 2^{-\mathrm{y}} \times \mathrm{z}= \\
& \mathbf{2}^{\mathrm{x}-\mathbf{y}} \times \mathbf{3}^{\mathrm{x}+\mathbf{y}} \times \mathbf{5}^{-\mathbf{x}} \times \mathbf{z}
\end{aligned}
$$

\footnotetext{
${ }^{253}$ Françoise Escal, na Introdução do livro Sémantique musicale: essai de psycho-physiologie auditive (1993), elabora uma fórmula para interpretar os procedimentos de Daniélou (ESCAL, 1993, p. 8), no entanto, consideramos a fórmula proposta por Piana mais clara e completa.

${ }^{254}$ Lembrando que um expoente negativo inverte o número de base, portanto $(3 / 2)^{-y}=\left({ }^{2} / 3\right)^{y}$.
} 
Esta fórmula, segundo Piana, "ilustra maravilhosamente o tema da redução de todos os intervalos musicalmente válidos (segundo Daniélou) aos números 2, 3 e 5,255 (PIANA, 2003, p. 45).

No sistema tonal, a palavra fundamental deriva da ideia de fundamental da série harmônica. Quando temos um acorde maior, é como se tomássemos os parciais 4, 5 e 6 de uma série harmônica cuja nota fundamental encontra-se duas oitavas abaixo do parcial 4 . Esses números que nomeiam cada parcial também são responsáveis pela proporção estabelecida entre suas frequências. Para continuarmos com a mesma proporção intervalar mesmo que chamássemos o parcial 4 de 1, ou fundamental, teríamos de dividir os outros componentes do acorde por 4 . Dessa forma eles se manteriam na mesma proporção sonora. $\mathrm{O}$ que nos daria a sequência numérica: $1,5 / 4 \mathrm{e}^{3} / 2$.

Desde que se mantenha a mesma proporção intervalar, podemos utilizar como referência outro parcial deste acorde. Se considerarmos o parcial 6 como 1, devemos dividir os outros componentes do acorde por 6 , de forma que manteremos a mesma proporção. Teremos então: ${ }^{2} / 3,5 / 6$ e 1 (em ordem crescente).

E podemos fazer o mesmo tomando como referência o parcial 5, bastando dividir os demais também por $5:{ }^{4} / 5,1 \mathrm{e}^{6} / 5$.

Como se trata apenas de um ponto de referência, este grupo de notas que formam um acorde maior, soará sempre da mesma maneira, porque nele os sons representados pelas notas terão sempre as mesmas proporções e se quisermos que essas proporções sejam representadas por números inteiros os cálculos nos farão encontrar os números 4, 5 e 6 que, com base na série harmônica, terá sempre como fundamental o número 1 , duas oitavas abaixo do parcial 4 , por isso podemos afirmar que 4, como classe de altura, é a fundamental deste grupo de notas [ver na Figura 3 abaixo os parciais 4, 5 e 6].

\footnotetext{
${ }^{255}$ illustra a meraviglia il tema della riduzione di tutti gli intervalli musicalmente validi (secondo Daniélou) ai numeri 2, 3 e 5
} 


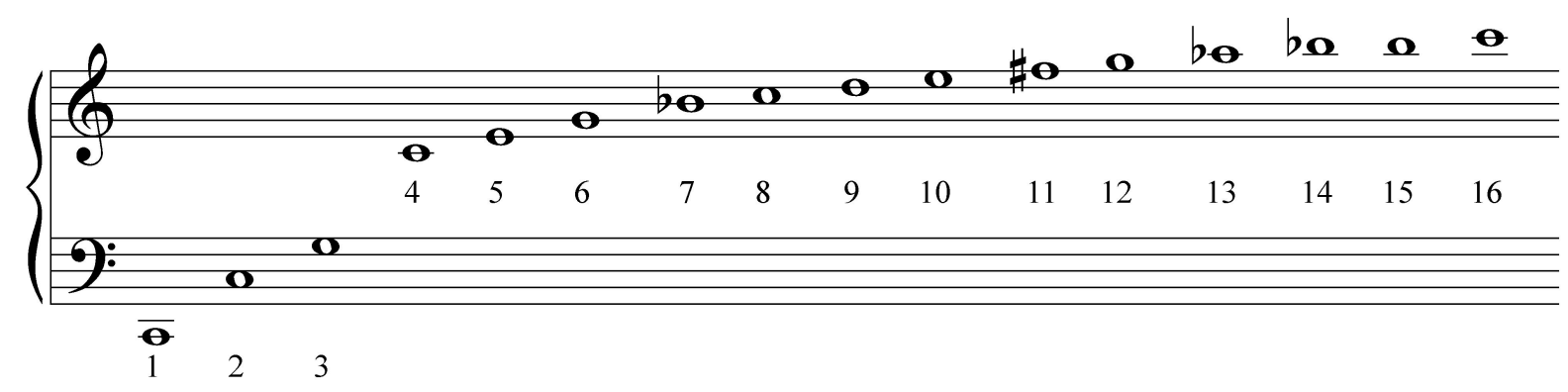

Figura 3: Série Harmônica com parciais de 1 a 16, (Os acidentes valem apenas para as notas em que estão grafados. Os parciais 7, 11, 13 e 14, respectivamente B , F\#, Ab e B b não aparecem na escala de Alain Daniélou pois são parciais que estão além dos múltiplos de 5)

Desta maneira, se quisermos encontrar a fundamental de um acorde, de uma escala, ou mesmo de uma grupo de notas quaisquer, será mais fácil encontrá-la se as proporções entre essas notas forem expressas em números inteiros, como parciais de uma série harmônica, e não em frações. O número dentro de uma oitava que contenha este acorde, escala ou grupo de notas, e que ao ser seguidamente dividido por dois nos dê como resultado o número 1 será a fundamental procurada. Esta fundamental nem sempre está presente ou explícita neste grupo.

Por exemplo, no acorde menor formado pelas proporções $1,6 / 5 \mathrm{e}^{3} / 2$ (e.g. Mi, Sol e Si) precisamos inicialmente transformar seus três elementos de forma que sejam representados por números inteiros. Para realizar esta operação, transformando proporcionalmente as frações em números inteiros, devemos encontrar primeiro o Mínimo Múltiplo Comum (MMC) dos denominadores, em seguida multiplicá-lo pelos numeradores e por fim resolver a divisão de cada fração. Vejamos:

Devemos primeiramente encontrar o MMC entre 1, 5 e 2, que nos dá o número 10; em seguida multiplicá-lo pelos numeradores, o que nos dá a seguinte sequência: 10, 60 e 30; e por fim resolver as frações resultantes: ${ }^{10} \frac{1}{1} ;{ }^{60} / 5 \mathrm{e}^{30} / 2: 10 \div 1=10 ; 60 \div 5=12$ e $30 \div 2=15$. Temos então a sequência de números inteiros proporcionais 10, 12 e 15 (além do 20 como oitava de 10). Como nenhum destes números pode ser dividido exclusivamente por dois até resultar em 1, a fundamental da série harmônica geradora dessas proporções não está explícita.

Dentro desta oitava entre dez e vinte, o único número que pode ser sucessivamente dividido por 2 até resultar em 1 é o número 16. Este número, se considerarmos o 10 como 1 , deveríamos dividi-lo por 10 encontrando a fração $16 / 10$ que pode ser simplificada e resulta em 8/5. Esta fração tem em relação ao 10 como 1 a relação intervalar de sexta menor ou Mi - Dó. $\mathrm{O}$ que nos leva a concluir que, a série harmônica geradora do acorde menor $\mathrm{Mi}$, Sol e Si, com 
as proporções especificadas acima é aquela formada a partir da fundamental Dó [ver na Figura 3 acima os parciais 10, 12 e 15].

Utilizando este mesmo raciocínio e cálculos, vemos abaixo que, tanto a escala pitagórica como a escala justa construída a partir da tônica Dó terão como fundamental a nota Fá:

\begin{tabular}{|c|c|c|c|c|c|c|c|c|c|c|c|c|c|c|}
\hline Escala & \multicolumn{7}{|c|}{ Pitagórica } & \multicolumn{7}{|c|}{ Justa } \\
\hline Notas & Dó & Ré & $\mathrm{Mi}$ & Fá & Sol & Lá & $\mathrm{Si}$ & Dó & Ré & $\mathrm{Mi}$ & Fá & Sol & Lá & $\mathrm{Si}$ \\
\hline Razões & 1 & $9 / 8$ & $81 / 64$ & $4 / 3$ & $3 / 2$ & $27 / 16$ & $243 / 128$ & 1 & $9 / 8$ & $5 / 4$ & $4 / 3$ & $3 / 2$ & $5 / 3$ & $15 / 8$ \\
\hline $\mathbf{N}^{\text {os }}$ Inteiros & 384 & 432 & 486 & 512 & 576 & 648 & 729 & 24 & 27 & 30 & 32 & 36 & 40 & 45 \\
\hline Fundamental & \multicolumn{7}{|c|}{ Fá $=512$ ou $4 / 3$} & \multicolumn{7}{|c|}{ Fá $=32$ ou $4 / 3$} \\
\hline
\end{tabular}

Tabela 7: Escala Pitagórica e Justa. Os números 512 e 32 são os únicos que podem chegar ao 1 ao serem sucessivamente divididos por 2 .

Temos aqui, portanto uma diferença entre tônica e fundamental, porque nestas mesmas escalas poderíamos considerar outras notas como tônica. Na música modal, as notas que possuem esta função recebem o nome de finalis. Porém, se preservarmos as mesmas proporções acima, não importa qual seria a tônica ou a finalis, a fundamental da série harmônica geradora destas escalas seria sempre a nota Fá.

Para facilitar a compreensão dos cálculos, Daniélou utiliza a palavra tônica quando se refere à nota que gera toda a escala, associando à nota Dó o número 1 (DANIÉLOU 1995, p. 138-140). Trata-se apenas de um ponto de referência, pois ao estabelecer relações com intervalos descendentes, esta tônica pode ser interpretada como um parcial.

É possível encontrar a fundamental da série harmônica geradora das 53 notas da escala de Alain Daniélou, e a nota Dó associada ao número 1 não deve ser confundida com ela. Abaixo a Escala Universal dos Sons de Daniélou com suas proporções em números inteiros, ou seja, com a numeração dos parciais ${ }^{256}$ :

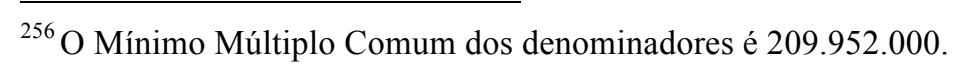




\begin{tabular}{|c|c|c|c|c|c|c|c|c|c|c|c|c|c|c|}
\hline & Nota & Parcial & & Nota & Parcial & & Nota & Parcial & & Nota & Parcial & & Nota & Parcial \\
\hline 1 & $C(\mathrm{Sa})$ & 209.952 .000 & & $1 / 4$ & $93 / 80$ & 23 & $F(M a)$ & 279.936 .000 & 34 & $\mathrm{G}++$ & 322.486 .272 & 44 & $A \#^{L-}$ & 369.056 .250 \\
\hline 2 & $\mathrm{C}+$ & 212.576 .400 & 13 & $\mathrm{D} \#$ & 246.037 .500 & 24 & $\mathrm{~F}+$ & 283.435 .200 & & $1 / 4$ & $31 / 20$ & 45 & $\mathrm{~B}^{\mathrm{L}+}$ & 373.248 .000 \\
\hline \multirow[t]{2}{*}{3} & $\mathrm{C}++$ & 214.990 .848 & 14 & $\mathrm{D} \#{ }^{\mathrm{L}}$ & 248.832 .000 & 25 & $\mathrm{~F}++$ & 286.654 .464 & 35 & $\mathrm{G} \#$ & 328.050 .000 & 46 & $\mathrm{Bb}$ & 377.913 .600 \\
\hline & $1 / 4$ & $\left(\frac{30}{31}\right)$ & 15 & $\mathrm{E}_{b}$ & 251.942 .400 & & $1 / 4$ & $62 / 45$ & 36 & $\mathrm{G} \#^{\mathrm{L}}$ & 331.776 .000 & & $3 / 4$ & $29 / 16$ \\
\hline 4 & $\mathrm{C} \#$ & 218.700 .000 & & $3 / 4$ & $75 / 62$ & 26 & $\mathrm{~F} \#$ & 291.600 .000 & 37 & $\mathrm{~A}_{b}$ & 335.923 .200 & 47 & $\mathrm{~B}-$ & 384.000 .000 \\
\hline 5 & $\mathrm{C} \sharp^{\mathrm{L}-}$ & 221.184 .000 & 16 & $\mathrm{E}-$ & 256.000 .000 & 27 & $\mathrm{~F} \#^{\mathrm{L}-}$ & 295.245 .000 & & $3 / 4$ & $50 / 31$ & 48 & B - & 388.800 .000 \\
\hline 6 & $\mathrm{D}_{b}{ }^{\mathbf{L}^{+}}$ & 223.948 .800 & 17 & $\mathrm{E}-$ & 259.200 .000 & 28 & $\mathrm{G}_{b}{ }^{\mathrm{L}+}$ & 295.245 .000 & 38 & $A-$ & 340.122 .240 & 49 & B (Ni) & 393.660 .000 \\
\hline \multirow[t]{2}{*}{7} & $\mathrm{D}_{b}$ & 226.748 .160 & 18 & $\mathrm{E}(\mathrm{Ga})$ & 262.440 .000 & 29 & $\mathrm{G}_{b}$ & 302.330 .880 & 39 & A- & 345.600 .000 & 50 & $B+$ & 398.580 .750 \\
\hline & $3 / 4$ & $135 / 124$ & 19 & $E+$ & 265.720 .500 & & $3 / 4$ & $90 / 62$ & 40 & A (Dha) & 349.920 .000 & 51 & $\mathrm{~B}++$ & 403.107 .840 \\
\hline 8 & $\mathrm{D}-$ & 230.400 .000 & 20 & $\mathrm{E}++$ & 268.738 .560 & 30 & $\mathrm{G}-$ & 307.546 .875 & 41 & $A+$ & 354.294 .000 & & $1 / 4$ & $60 / 31$ \\
\hline 9 & $\mathrm{D}-$ & 233.280 .000 & & $1 / 4$ & $31 / 24$ & 31 & $\mathrm{G}-$ & 311.040 .000 & 42 & $\mathrm{~A}++$ & 358.318 .080 & 52 & $\mathrm{C}-$ & 410.062 .500 \\
\hline 10 & $D(R e)$ & 236.196 .000 & 21 & $\mathrm{~F}-$ & 273.375.000 & 32 & $G(P a)$ & 314.928 .000 & & $1 / 4$ & $31 / 18$ & 53 & $\mathrm{C}-$ & 414.720 .000 \\
\hline 11 & $\mathrm{D}+$ & 238.878 .720 & 22 & $\mathrm{~F}-$ & 276.480 .000 & 33 & $\mathrm{G}+$ & 318.864 .600 & 43 & $A \#$ & 364.500 .000 & 54 & $C(S a)$ & 419.904 .000 \\
\hline 12 & $\mathrm{D}++$ & 243.000 .000 & & & & & & & & & & & & \\
\hline
\end{tabular}

Tabela 8: Escala Universal dos Sons de Alain Daniélou com subdivisões, notas e parciais. Em sombreado as notas da escala Justa, em negrito e itálico as da escala Pitagórica. Dó, Ré, Fá e Sol pertencem às duas.

[foram calculados apenas as 53 notas numeradas que pertencem à escala].

Notamos após estes cálculos que a fundamental desta escala não está explícita, tratarse-ia da nota representada pelo parcial número 268.435.456, que em sua forma de fração proporcional à nota Dó seria $268435456 / 209952000$ e que ao ser simplificada, dividindo o numerador e o denominador por 256, nos daria a razão 1048576/820125 [ou $2^{20} /\left(3^{8} \times 5^{3}\right)$ ]. Este é o único número que se encontra na região da oitava que vai do parcial 209.952 .000 até o parcial 419.904.000 que ao ser sucessivamente dividido por 2 resulta no número 1. Esta fundamental se encontra entre as notas 19 e 20 da escala, entre $\mathrm{Mi}+$ e $\mathrm{Mi}++$.

É como se a partir de uma série harmônica cuja fundamental se encontra entre $\mathrm{Mi}+\mathrm{e}$ $\mathrm{Mi}++$, escolhêssemos apenas alguns parciais (múltiplos de 2, 3 e 5) compreendidos entre a oitava formada pelos parciais 209.952.000 e 419.904.000.

Daniélou é um defensor não apenas da música modal, mas também das afinações naturais, considerando que o temperamento, principalmente o temperamento igual, não é capaz de proporcionar todos os efeitos pertinentes e possíveis às relações intervalares presentes na música.

Afirma que "o poder de evocação do sistema harmônico como é concebido hoje é 
fraco e confuso se comparado com qualquer sistema modal"257 (DANIÉLOU, 1995, p. 122), e que "a ideia de representar fenômenos naturais, ou o movimento das coisas e seres, imitando os ruídos que eles fazem parece infantil à maneira de pensar oriental ${ }^{258}$ (Idem, p. 123). E completa com um exemplo indiano:

Por exemplo, quando o modo indiano das chuvas, Megh-Mallar, é tocado, nenhum som irá tentar imitar o ruído de gotas de chuva ou de trovão, mas as relações entre os sons será tão similar àquelas entre os elementos quando uma tempestade se aproxima que não apenas músicos treinados mas mesmo animais sentirão inevitavelmente a chuva no ar. ${ }^{259}$ (Ibidem)

Com relação ao temperamento igual ele considera:

Geralmente é dito que o ouvido pode reconhecer o verdadeiro intervalo representado pelo intervalo temperado. Isto é um fato; mas cada ouvido faz uma adaptação diferente de acordo com tendências individuais, e o mesmo acorde pode ter um significado diferente para diferentes pessoas de acordo com seu humor. O significado de um acorde preciso, por outro lado, é determinado de forma absoluta e percebido por todos. ${ }^{260}$ (Idem, p. 121-122)

Porém faz uma ressalva quando se trata de instrumentos sem trastes ou do canto, ou que não possuem uma afinação fixa. A teoria ocidental que embasa o sistema de temperamento igual "não parece notar que os intervalos utilizados por músicos orientais e por grandes violinistas ocidentais são, para o ouvido imparcial dos instrumentos de medição sonora, geralmente idênticos"261 (Idem, p. 83), e que "violinistas e cantores ficam geralmente bastante surpresos se alguém mede o intervalo que eles estão realmente cantando. Estes frequentemente diferem amplamente daqueles que eles acreditam firmemente estarem reproduzindo" 262 (Idem, p. 106).

\footnotetext{
${ }^{257}$ the power of evocation of the harmonic system as it is conceived today is weak and confused if compared with any modal system

${ }^{258}$ the idea of representing natural phenomena, or the movement of things and beings, by imitating the noises they make appears childish to the Eastern way of thinking

${ }^{259}$ For example, when the Indian mode of the rains, Megh-Mallar, is played, no sound will attempt to imitate the noise of raindrops or of thunder, but the relations between the sounds will be so similar to those between the elements when a storm is approaching that not only trained musicians but even animals will inevitably feel the rain in the air.

${ }^{260}$ It is generally said that the ear can recognize the true interval represented by the tempered interval. This is a fact; but each ear makes a different adaptation according to individual tendencies, and the same chord may have a different significance for different people according to their mood. The meaning of an accurate chord, on the other hand, is determined absolutely and perceived by all.

${ }^{261}$ do not seem to realize that the intervals used by Eastern musicians and by great Western violinists are, for the impartial ear of sound-measuring instruments, generally identical

${ }^{262}$ violinists and singers are usually most surprised if one measures the interval they are actually singing. These often differs widely from those they firmly believe themselves to be reproducing
} 
Este desvio deve-se à entonação durante a performance e, segundo Flo Menezes, com base nestas entonações Helmholtz afirmava a superioridade da escala justa, pois instrumentistas de corda em geral realizavam desvios do sistema temperado

executando intervalos justos e não temperados. Equipamentos modernos de medição auxiliaram os cientistas a um exame mais preciso e chegou-se à conclusão, porém, de que tais desvios do temperamento igual na performance, de fato existentes ocasional e circunstancialmente, dão-se no sentido de se executarem antes de tudo intervalos pitagóricos. (MENEZES, 2003, p. 268 destaques do autor)

No entanto esta não é uma questão unânime. A violinista Mieko Kanno mostra como outra violinista, Janina Fyk em seu livro Melodic Intonation, psychoacoustics, and the violin, descreve quatro tipos diferentes de entonações ou afinações expressivas, que em nosso caso específico citaremos apenas duas.

A primeira é a "afinação harmônica: [...] Muitos dos desvios do temperamento igual ocorrem na tentativa de afinar na afinação justa com a harmonia subjacente",263 e "afinação melódica: observa-se que a entonação é elevada no contexto de uma melodia ascendente e abaixada no contexto de uma melodia descendente ${ }^{264}$ (FYK, 1995 apud KANNO, 2003, p. 36), ao que complementa em nota de rodapé com outra citação, desta vez de Patricia e Allen Strange e seu livro The contemporary violin: extended performance techniques: "observa-se em outros lugares que instrumentistas de cordas têm uma tendência natural de tocar na afinação Pitagórica, fazendo o intervalo de terça maior mais amplo, e o de terça menor mais estreito, do que os equivalentes do temperamento igual" ${ }^{265}$ (STRANGE \& STRANGE, 2001 apud KANNO, 2003, p. 52n).

Nota-se aqui que a entonação durante a performance pode ser guiada conforme a linha melódica que se está tocando, se o instrumentista está fazendo o papel de solista ou de acompanhamento, o que exige diferentes entonações, mais próximas da afinação pitagórica ou justa respectivamente.

Por sua vez, Ross W. Duffin em seu livro intitulado sintomaticamente How equal temperament ruined harmony (and why you should care) [Como o temperamento igual arruinou a harmonia (e porque você deveria se importar)], faz um ataque veemente ao

\footnotetext{
${ }^{263}$ Many of the deviations from equal temperament take place in trying to tune in just intonation with the underlying harmony

${ }^{264}$ it is observed that the intonation is raised in the context of an ascending melody, and it is lowered in the context of a descending melody

${ }^{265}$ It has been observed elsewhere that string players have a natural tendency to play in Pythagorean intonation, making the major third interval wider, and the minor third narrower, than equal temperament equivalents.
} 
temperamento igual (assim como Daniélou), porém ele é mais flexível com respeito à utilização de outros temperamentos desiguais.

Quanto ao título do livro ele afirma: "Eu apresso-me a esclarecer que eu não chamei este livro 'Como o Temperamento Igual Arruinou a Música'. Eu não acredito nisto. É o som da música, a harmonia, que foi comprometida pelo uso exclusivo de TI na performance,266 (DUFFIN, 2007, p. 17-18 destaque do autor).

Nota-se aqui que ele faz uma pequena diferenciação entre música e som da música. Longe de parecer absurdo, se pensarmos na música como uma linguagem, podemos pensar nela existindo independentemente de estar soando, porém tal discussão não cabe aqui ${ }^{267}$.

Duffin afirma ainda que

por muitos anos eu fui um franco defensor da afinação justa na performance de obras antigas - principalmente renascentistas - para grupo vocal, mas com o início da era barroca, eu não penso que ela funcione bem, e eu não penso que era isso que os compositores tinham em mente para sua própria música, exceto, talvez, para passagens de harmonia excepcionalmente estáveis. ${ }^{268}$ (DUFFIN, 2007, p. 70)

Vemos então que a utilização de afinações naturais ou de temperamentos diferentes do temperamento igual, que segundo Duffin foi adotado plenamente apenas em $1917^{269}$ (DUFFIN, 2007, p. 138-140), depende não apenas de um acidente de percurso de um instrumentista, como pode querer fazer crer a frase de Flo Menezes acima, mas também de estilo, época e interpretação, ou seja, depende de uma intenção e vontade, tanto do compositor quanto, principalmente, do instrumentista.

Alain Daniélou tem outra justificativa para a utilização dos intervalos naturais. Para

\footnotetext{
${ }^{266}$ I hasten to point out that I didn't call this book 'How Equal Temperament Ruined Music.' I don't believe that. It's the sound of music, the harmony, that has been compromised by exclusive use of ET in performance.

${ }^{267}$ Para mais informações a respeito de como se pode discutir o "lugar" da música cf. ZAMPRONHA, Edson Sekeff. Onde está a música?. ARTEunesp, São Paulo, v.12, p. 115-33, 1996.

${ }^{268}$ For many years I have been an outspoken advocate of Just intonation in the performance of early - mainly Renaissance - vocal ensemble works, but beginning with Baroque era, I don't think it works well, and I don't think it's what the composers had in mind for their own music, except, perhaps, for passages of unusually stable harmony.

${ }^{269}$ Com relação à data de adoção universal do Temperamento Igual, existem divergências. Segundo Gaínza, o Temperamento Igual "não é aceito universalmente até aproximadamente 1870" (GAÍNZA, 1992, p. 118), porém, o ano de 1917 é apontado por Duffin como referência para a adoção universal do Temperamento Igual devido a fatores que vão desde o mercado crescente da venda de pianos, do contexto social e político da época, até o pensamento positivista presente neste período. Ele sustenta este ano (1917) baseado no relato de diversos afinadores do século XIX, em que descreviam seu processo de afinação e temperamento. A descrição destes processos são analisados no capítulo 7: Some are more equal than others, de seu livro How equal temperament ruined harmony (DUFFIN, 2007, p. 104-118). Tais análises revelam que os temperamentos obtidos, embora muito próximos, não correspondiam ao Temperamento Igual utilizado posteriormente, principalmente a partir de 1917.
} 
ele, como o cérebro funciona como uma espécie de computador operando em três linguagens simultaneamente, binária, ternária e quinária, todo intervalo que não corresponder a uma destas linguagens é como que corrigido pelo cérebro para que ele possa interpretá-lo, dessa forma ocorreria uma fadiga em nosso aparelho áudio-mental. Por isso sua escala divide a oitava em 53 partes e, mesmo que existam outras teorias que trabalham com essa mesma divisão, porém de forma temperada, a opção de Daniélou é pelos intervalos naturais derivados de 2, 3 e 5, uma opção relacionada com a cognição que veremos no próximo capítulo. 


\section{Cognição Musical}

Este aspecto de sua obra é abordado no livro Sémantique Musicale (Semântica Musical) que, como observamos no subcapítulo 2.3. Semântica Musical da Parte 1, foi publicado originalmente em 1967, tendo uma segunda edição com prefácio de Françoise Escal em 1978, com uma nova tiragem em 1993.

Consideramos a Cognição Musical como o aspecto mais frágil do trabalho de Alain Daniélou. Frágil aqui não significa que ele seja fraco ou que seu trabalho não esteja suficientemente fundamentado, utilizamos frágil aqui no sentido de que se deve manusear com cuidado, para que nenhuma consideração mais apressada possa, de forma desastrada, desmantelar algo que possa contribuir para nosso entendimento musical, ainda que possamos enxergar os percursos fugidios de sua acepção. Mesmo assim entendemos que as direções que tomaram as pesquisas neste campo tornaram as investigações de Daniélou se não obsoletas, ao menos de pouco interesse geral. É necessário enumerar algumas características que podem nos servir para uma melhor compreensão desta situação.

Consideramos como uma primeira fragilidade uma espécie de confiança no aspecto quantitativo do som e consequentemente da música. Daniélou considera a percepção musical como uma leitura dos dados captados pelo ouvido, e que devido à natureza do tímpano - que por ser uma membrana comportar-se-ia como um tambor -, estes dados, os sons, seriam lidos não como feixes de frequências, mas como resultados de pressões e depressões nesta membrana, que posteriormente serão interpretados pelo cérebro adquirindo determinada significação.

Ainda que verossímil, esta ideia nos parece uma espécie de confiança exacerbada no aspecto físico ou natural, em detrimento do aspecto cultural. Estamos aqui nos referindo ao tema dos possíveis universais na música, a natureza e a cultura - como os mostra Meyer (2001), ou a natureza e a história - como quer Fubini (2001a) [cf. p. 103 e 104 acima].

Uma segunda fragilidade é o fato que, por considerar a música uma linguagem, apoiase na Cibernética de Norbert Wiener. Essa opção de Daniélou, embora se mostre coerente com a maneira pela qual ele buscou justificar sua acepção da semântica musical, torna-se frágil porque a cibernética não é exatamente uma teoria psicológica ou cognitiva e sim uma teoria da comunicação.

Como terceira fragilidade apontamos o fato de que quando busca afirmar que a música é capaz de uma comunicação objetiva de ideias, diz que somente a música que utiliza 
afinações naturais seria capaz de fazê-lo e que somente dessa maneira a música seria capaz de produzir significações determinadas. Esta forma de entendimento acaba por valorizar a música modal, e neste caso específico a música indiana da qual ele foi um grande estudioso, de modo que deixaria dúvidas quanto à imparcialidade de sua pesquisa neste campo. Além disso, entende a música como veículo e não como fim em si mesmo, e assim despreza a fruição puramente estética.

Antes de nos concentrarmos em cada uma dessas fragilidades, faremos um breve resumo de como Daniélou entende a interpretação da música por nosso aparelho áudiomental. ${ }^{270}$

Daniélou entende que o cérebro funciona como um computador que lê em três linguagens simultâneas: binária, ternária e quinária. Para isto apoia-se no fato de que a percepção auditiva é similar à de outros sentidos, adotando a ideia de Julian Huxley em seu texto Psychometabolism, que afirma que visualmente só podemos apreender sem racionalizar quantidades totais até um máximo de cinco, a partir daí para apreendermos determinadas quantidades subdividimos o total em subconjuntos dessas quantidades, por exemplo, seis objetos seriam subdivididos em dois grupos de três, e sete em dois grupos, um de quatro e outro de três, e assim por diante.

A partir da informação de que a faixa de frequência entre $10 \mathrm{~Hz}$ e $15 \mathrm{~Hz}$ aproximadamente, é uma região híbrida, de passagem, em que o som pode ser identificado ora como som, ora como ritmo - faixa em que se encontram as ondas Alfa, que seria um tipo de regulador dos ritmos em nosso corpo - chega à conclusão de que nossa percepção trabalha com um contínuo entre duração e altura.

Esta ideia embasa também a teoria da Unidade do Tempo Musical de Stockhausen publicado originalmente em 1961. Considerando que Daniélou volta da Índia à Europa, instalando-se em Paris em 1960, existe a possibilidade de ele ter tomado contato com o texto de Stockhausen pois, como dissemos, Sémantique Musicale foi publicado em 1967. No entanto, já na edição original de Music and the Power of Sound intitulada Introduction to the study of musical scales (1979) publicada originalmente em Londres em 1943, ele já faz referência a esse contínuo entre duração e altura. Não entendemos que o atributo de primordialidade seja importante neste caso, talvez tal semelhança tratar-se-ia apenas de uma espécie de "espírito do tempo".

Daniélou então parte do princípio de que, como o tímpano é uma membrana e há um

\footnotetext{
${ }^{270}$ Para maiores detalhes ver o subcapítulo 2.3. Semântica Musical da Parte 1 acima.
} 
contínuo entre duração e frequência, o ouvido interpretaria o som, e portanto a música, como uma combinação de pressões e depressões no tímpano, pois dessa forma apreenderíamos de maneira imediata os agrupamentos de 2, 3 e 5, bem como seus múltiplos e em diversas combinações. Tais combinações seriam responsáveis pelas relações intervalares.

Cada uma dessas relações intervalares, por possuírem combinações diferentes, caminharia por circuitos cerebrais diferenciados, mesmo que fossem intervalos muito próximos para nossa cultura. Dessa forma, por exemplo, uma teç̧a maior pitagórica cuja relação é de ${ }^{81} / 64$, que poderíamos simplificar como $3^{4} / 2^{6}$, ou seja, como derivado de 2 e de 3 , trabalhando portanto com as linguagens binária e ternária, é um intervalo completamente diferente da terça maior justa, cuja relação é de $5 / 4$, ou $5 / 2^{2}$, que trabalha com as linguagens quinária e binária.

O nome terça deve-se à ordenação da escala heptatônica, que ao denominar tais intervalos como terça (aos quais poderíamos acrescentar a terça do sistema temperado, que soaria entre as duas) aproxima-os e então a partir daquele que estabelecemos como padrão atualmente a terça temperada - tornaria os outros dois uma espécie de distorção do padrão, que aprendemos a identificar como desafinação ou como uma pequena diferença tímbrica.

Porém, para os indianos, por exemplo, seriam intervalos completamente diferentes, o que Daniélou atribui ao fato de serem trabalhados cognitivamente em circuitos cerebrais diferentes.

Atribuindo determinadas significações a cada linguagem, Daniélou considera cada combinação entre elas resultado das relações intervalares. A linguagem binária é estática, formando um quadro temporal ou espacial, a linguagem ternária é motor, responsável pelo movimento, enquanto a linguagem quinária é emocional. Desse modo, a terça pitagórica ${ }^{81} / 64$, ou $3^{4} / 2^{6}$, seria motor-espacial, enquanto a terça maior justa $5 / 4$, ou $5 / 2^{2}$, seria emotivoespacial, portanto com diferentes significações.

Quando se trata de intervalos que não se encaixam em uma dessas três linguagens, a terça maior temperada por exemplo, o cérebro corrigiria este desvio encaixando-os em um intervalo que pertença a uma das três linguagens. Esta correção dar-se-ia de acordo com o estado físico-emocional do ouvinte, o que justificaria as percepções diferenciadas e atribuições de significados diferentes para uma mesma música de acordo com o ouvinte ou com o momento em que um mesmo ouvinte aprecia determinada música. Caso a música fosse executada com o intervalo preciso, pertencente a uma dessas três linguagens, o cérebro não necessitaria fazer esta correção e as atribuições ou interpretações de significado seriam sempre as mesmas. Segundo Daniélou, esta constante correção produziria uma fadiga mental 
no ouvinte.

Com relação aos fatores acima do 5, especialmente o fator 7, Daniélou considera que ele sai das possibilidades da linguagem musical. "Aparentemente nós não temos nenhuma engrenagem mental que nos permita classificar um intervalo onde aparece o fator 7 ou de associar-lhe reações emotivas"271 (DANIÉLOU, 1993, p. 48). Ele produziria o mesmo efeito do intervalo temperado, pois o interpretaríamos como pertencendo a alguma série do fator 3 ou 5, já que o fator 7 "não tem conteúdo expressivo, não tem significação em nosso mecanismo de classificação"272 (Ibidem) produzindo também uma fadiga mental.

Em outro momento Daniélou atribui esta imprecisão do fator sete a outro motivo: "sete é o número dos mundos celestiais assim como das regiões infernais, e nós geralmente não temos meios de saber para qual lado ele pode nos levar"273 (DANIÉLOU, 1995, p. 137).

É interessante notar no caso do fator 7, o que Juan G. Roederer, em seu livro Introdução à física e psicofísica da música (1998), nos informa: os sons percebidos são decompostos em parciais harmônicos pela membrana basilar no ouvido, de maneira que "para harmônicos de ordens superiores ( $n$ maior que 7 ou 8), essa relação perde a sua definição física por causa das superposições mútuas de ressonância” (ROEDERER, 1998, p. 94-95).

Vemos aqui um exemplo de que imediatamente somos tentados a acreditar em Daniélou apenas depois de sabermos a informação de Roederer, porque existiria uma explicação física para esta justificativa que ele nos dá a respeito da impossibilidade da identificação clara e inequívoca do fator 7 , seja por meios místicos ou simbólicos, seja por meios psicológicos. De forma que pensamos que realmente exista a possibilidade de que esta “superposição mútua de ressonâncias" citada por Roederer, pode tanto causar ambiguidade na audição, pois "não temos meios de saber para qual lado ele pode nos levar", como uma "fadiga mental", pois ora o interpretaríamos como pertencentes ao fator 5 , ora ao fator 3.

Em linhas gerais são estas as acepções de Daniélou para uma semântica musical. Passemos a analisar as fragilidades que apontamos acima.

Com relação à primeira fragilidade, a confiança no aspecto quantitativo, afirmamos que embora verossímil - já que de fato o tímpano é uma membrana e a ideia de que ele funcionaria como um tambor não é absurda -, despreza o aspecto cultural valorizando apenas o fisiológico. Esta forma de entender o dado musical leva-o a afirmar a ideia das três

\footnotetext{
${ }^{271}$ Nous n'avons apparemment aucun rouage mental qui nous permette de classifier un intervalle où apparaît le facteur 7 ou de lui associer des réactions émotives

${ }^{272}$ n'a pas de contenu expressif, pas de signification dans notre mécanisme de classification

${ }^{273}$ seven is the number of the heavenly worlds as well as that of the infernal regions, and we usually have no means of knowing to which side it may lead us
} 
linguagens, binária, ternária e quinária e à ideia de que o cérebro corrigiria os intervalos não correspondentes a essas linguagens, fazendo-nos sofrer uma fadiga mental.

De fato há uma fragilidade aqui, porém os estudos de cognição musical atuais, principalmente aqueles ligados à neurociência, detectam que existem lacunas com relação a algumas percepções. Daniel J. Levitin em A música no seu cérebro: a ciência de uma obsessão humana observa que

\begin{abstract}
embora as áreas do cérebro que reagem às alturas específicas tenham sido mapeadas, ainda não descobrimos a explicação neurológica da codificação das relações de altura; sabemos, por exemplo, que parte do córtex é mobilizada na audição das notas dó ou mi, ou fá e lá, mas não sabemos como nem por que os dois intervalos são ouvidos como uma terça maior, nem identificamos os circuitos neurais que estabelecem essa equivalência perceptiva. Essas relações devem ser estabelecidas no cérebro por processos de computação que ainda não foram muito bem identificados. (LEVITIN, 2010, p. 41-42 destaque nosso)
\end{abstract}

Ao estabelecer a ideia de linguagens numéricas para a cognição musical, Daniélou compara nosso cérebro com o computador, que trabalha apenas com a linguagem binária. Estaria Daniélou identificando estes "processos de computação", referidos por Levitin como não identificados?

Em outro momento Levitin afirma que "nosso cérebro considera iguais as durações semelhantes, arredondando algumas para cima e outras para baixo, para tratá-los como simples coeficientes de números inteiros, como 2:1, 3:1 e 4:1" (LEVITIN, 2010, p. 78). Este arredondamento nos parece bastante próximo daquilo que Daniélou considera causador de uma fadiga mental, decorrente de uma constante correção cerebral da informação recebida, encaixando a informação em uma linguagem conhecida, que é o que aparentemente Levitin atribui aos coeficientes de números inteiros.

Apesar da fragilidade apontada por nós, a respeito da valorização do aspecto fisiológico cerebral, vemos que a neurociência cognitiva não mudou muito a esse respeito:

Um dos princípios fundamentais da neurociência cognitiva é que o cérebro fornece a base biológica de quaisquer comportamentos ou pensamentos que experimentamos, de modo que em algum nível deve haver uma diferenciação neural sempre que houver uma diferenciação comportamental. (LEVITIN, 2010, p. 78-79)

Temos aqui também uma predominância do aspecto fisiológico, ainda que se refira a comportamentos, nos parece que estes só poderiam ser mudados se houvesse também uma 
mudança neural, de forma que o aspecto cultural dependeria também, ou ao menos possuiria alguma influência, do processamento neural. No entanto, Levitin afirma depois que "nosso cérebro aprende uma espécie de gramática musical específica de nossa cultura, exatamente como acontece com a linguagem" (Idem, p. 123).

E ainda que o mesmo Levitin considere que "a verdade está em algum ponto entre os dois extremos, numa mistura das duas hipóteses que se defrontam no debate natureza/cultura" (Idem, p. 226) e que "a maioria dos cientistas e filósofos contemporâneos considera que o cérebro e a mente são duas partes de um todo, e alguns chegam a acreditar que a própria distinção é equivocada" (Idem, p. 98), nota que "o ponto de vista que hoje prevalece é o de que o conjunto de pensamentos, crenças e experiências é representado em padrões de descargas - atividade eletroquímica - no cérebro" (Ibidem); porém, continua, "a atividade cerebral dá origem aos conteúdos mentais" (Idem, p. 97) e quando o cérebro "deixa de funcionar, a mente se vai" (Idem, 98), ou seja, trata-se de uma postura que valoriza o aspecto fisiológico, da mesma forma que Daniélou.

O que consideramos uma segunda fragilidade, o apoio de Daniélou na Cibernética, que é uma teoria da comunicação, atribuímos ao fato de que ele considera a música uma linguagem. Temos aqui uma ambiguidade: se a fragilidade é o apoio na cibernética, por esta ser uma teoria da comunicação, ou se é o fato de ele considerar a música uma linguagem.

Aparentemente, considerar a música como uma linguagem não é nenhum absurdo e, sendo assim, utilizar uma teoria da comunicação para entender esta linguagem parece ser a escolha mais óbvia. No entanto, se a música não fosse considerada uma linguagem, ela seria o quê exatamente?

Como nos informa Ana Carolina Rocha Pessoa Temer e Vanda Cunha Albieri Nery, na obra Para entender as Teorias da Comunicação, a Cibernética faria parte, dentro do campo das Teorias da Comunicação, do Paradigma Matemático Informacional, que

valoriza as pesquisas matemáticas, as experiências laboratoriais. $\mathrm{O}$ Paradigma Matemático Informacional está ligado a tentativas de profissionais das Ciências Exatas em entender e agilizar os processos de transmissão e troca de informações, e se propõe a reduzir o processo comunicativo a expressões matemáticas simples, de fácil compreensão, mas que desconsideravam as consequências ou os efeitos do processo. (TEMER; NERY, 2012. p. 81)

Esta definição parece não se encaixar muito bem com o que nos diz Jocelyn Benaton em $O$ que é Cibernética, informando-nos que 
afastando-se da visão linear de pares "causa e efeito", ela busca um enfoque mais globalizante da realidade, onde fenômenos vários e díspares possam ser reunidos e compreendidos simultaneamente. (BENATON, 1986, p. 82)

Entendemos esta segunda definição do enfoque da Cibernética mais próxima da forma como Daniélou a utiliza Sémantique Musicale, pois entende que o cérebro trabalharia com três linguagens, necessitando portanto, de uma análise que pudesse dar conta da compreensão desses fenômenos simultaneamente.

Com relação à linguagem, Levitin relata, após experiência com pessoas ouvindo música clássica, que

os aspectos de gratificação e reforço do ato de ouvir música parecem ser mediados por níveis crescentes de dopamina no núcleo acumbente e pela contribuição do cerebelo para a regulação da emoção, mediante suas conexões com o lobo frontal e o sistema límbico. As atuais teorias neuropsicológicas associam os afetos e os estados de ânimo positivos a níveis crescentes de dopamina, um dos motivos pelos quais muitos dos novos antidepressivos atuam no sistema dopaminérgico. Com toda evidência a música é uma forma de melhorar o estado de ânimo das pessoas. (LEVITIN, 2010, p. 215)

Pois

a música aparentemente imita certas características da linguagem e transmite algumas das mesmas emoções que a comunicação oral, mas de uma forma não referencial e não específica. Também mobiliza algumas das mesmas regiões neurais que a linguagem, mas, muito mais que essa, a música recorre a estruturas cerebrais primitivas envolvidas com a motivação, a gratificação e a emoção. (Ibidem, destaque nosso)

Ora, se a música imita é porque ela não é linguagem, porém aqui perguntamos, ela está além ou aquém desta? Ela não é mais linguagem, ou ainda não é linguagem? Se ela "transmite algumas das mesmas emoções que a comunicação oral, mas de uma forma não referencial e não específica" poderíamos dizer que ela ainda não é linguagem, está aquém desta; se ela "mobiliza algumas das mesmas regiões neurais que a linguagem, mas, muito mais que essa, a música recorre a estruturas cerebrais primitivas envolvidas com a motivação, a gratificação e a emoção”, poderíamos dizer que ela já não é mais linguagem pois estaria além dela.

Por outro lado, John A. Sloboda afirma que "de um ponto de vista psicológico, a linguagem é, de certo modo, um substituto da experiência sensorial" (SLOBODA, 2008, p. 75 destaque nosso). Esta maneira de descrever a linguagem é especialmente válida para 
atribuirmos algum tipo de significado à música, pois se a imaginarmos desta maneira, ela não seria a responsável direta pela produção de emoções e sim uma espécie de gatilho para determinadas experiências sensoriais, que seriam completamente dependentes de quem as ouve, o que de certo modo questionaria a ideia da música como transmissão dos sentimentos, abrindo um espaço para a consideração da música de forma autônoma.

Mesmo Hanslick, em seu Do Belo Musical, não nega que a música possa despertar sentimentos quando afirma: "não queremos de todo subestimar os próprios sentimentos fortes que a música desperta da sua letargia, todos os estados de ânimo doces ou dolorosos em que ela nos embala, semi-sonhadores" (HANSLICK, 2011, p. 15).

No entanto, entendemos esta frase de Hanslick no sentido em que Sloboda destaca a ideia de que a linguagem seria um "substituto da experiência sensorial". Ele acrescenta que "nós respondemos quando nos dizem que deixamos os faróis acesos da mesma maneira que responderíamos se o víssemos acesos. Os teóricos contemporâneos dão conta desta equivalência dizendo que os dois inputs têm efeitos equivalentes em nossas representações mentais do mundo" (SLOBODA, 2008, p. 75 destaque do autor), ou seja, não foi a frase comunicando-me dos faróis acesos que despertou em mim determinadas sensações, mas a informação que ela transmitiu, ou o seu conteúdo. No caso da música tal comparação acaba necessitando um pouco mais de atenção porque inevitavelmente viria a pergunta: Qual é a informação, ou o conteúdo da música?

Por isso entendemos que a ideia de que a música é uma linguagem deva ser discutida de maneira mais ampla, o que fugiria aqui do escopo desta tese. Independente desta discussão, o fato é que Daniélou parte desta afirmação, pois se baseia na cultura indiana em que a linguagem total compreenderia a linguagem articulada, a linguagem musical e o gesto de maneira interdependentes (DANIÉLOU, 1993, p. 79).

Sendo assim, a partir das informações sobre a Cibernética, e das afirmações de Levitin, identificamos que a fragilidade de Daniélou neste caso, seria a de assumir a música como uma linguagem, de não questionar esta concepção, e não exatamente o fato de utilizarse da Cibernética, que neste caso acaba revelando-se coerente com sua acepção.

Quanto à terceira fragilidade, a de que a possibilidade de comunicação objetiva através da música só é possível por meio das relações intervalares naturais, proporcionadas por meio da afinação natural e não temperada, e que isso poderia colocar em risco sua imparcialidade científica, valorizando a música modal e indiana, além da ideia da música como veículo desvalorizando a ideia da fruição puramente estética, notamos que há aqui também coerência.

Identificamos como fragilidade pelo fato de que adota uma visão da música voltada 
exclusivamente para a ideia de transmissão de conteúdo extramusicais: ideias, sentimentos, sensações. Concepção esta questionada no ocidente, pelo menos de maneira mais contundente, no mínimo desde $O$ belo musical de Eduard Hanslick citado há pouco.

Porém, apontamos coerência porque Daniélou adota a acepção musical hindu, inclusive se converteu à religião Shivaísta ${ }^{274}$, acrescentando-se que se considerava mais um indiano do que um francês, desse modo sua postura estaria coerente com sua visão de mundo. A ideia de que a música deveria transmitir aspectos cósmicos precisos, bem como ideia e sentimentos e evocasse a forma de agir da natureza ou do princípio divino, está presente na forma como a música modal é executada, pois ao tocar sempre a mesma nota na mesma altura, estabelecendo sempre a mesma relação com o bordão, esta música como que "afinaria" o ouvinte.

As fragilidades apontadas a respeito da obra de Daniélou citadas neste capítulo, nos parecem mais fragilidades da própria área (ou diríamos características?), da semântica musical ou da cognição musical, do que necessariamente defeitos ou fraquezas do pensamento de Daniélou. As palavra frágil ou fragilidade aqui não carregaria esta conotação, ela denotaria uma necessidade de se pesquisar mais amplamente a relação entre música e cognição para que se amadureça mais este campo de pesquisa.

\footnotetext{
${ }^{274}$ Ainda que, como sugere Jean-Louis Gabin (2010), possa ser um Shivaísmo inventado [Cf. p. 34 acima].
} 


\section{PARTE 3}

\section{CONCLUSÕES:}

\section{APREENDENDO ALAIN DANIÉLOU}




\section{APREENDENDO ALAIN DANIÉLOU}

O existente não é a medida do possível. (DAHLHAUS, 2003, p. 123)

Começa aqui o término desta tese. Após passar pelas explicações e implicações, entendendo e estendendo o trabalho musical de Alain Daniélou, chega agora a hora de apreender o que ele nos propõe e daquilo que ele nos coloca conseguir enxergar o que pode vir adiante impulsionado por essas propostas.

Tratamos o trabalho de Daniélou como uma interpretação, como uma proposta, desta forma evitamos sempre que possível a palavra conceito, considerando seu trabalho como uma acepção do que é música, uma redescrição cujo efeito é o de ampliar a nossa compreensão, substituindo desta forma, como propõe Rorty, "metáforas de profundidade por metáforas de amplitude [porque] quanto mais descrições estiverem disponíveis e quanto maior a integração entre elas, melhor nossa compreensão do objeto identificado por qualquer dessas descrições" (RORTY, 2008, p. 3).

Tal maneira de abordar seu trabalho nos aproxima da própria maneira como Daniélou abordava seus estudos, partindo da doutrina indiana do darshana ou pontos de vista, em que qualquer assunto seria filtrado por seis métodos: cosmologia, yoga, ritos, metafísica, ciência e lógica aos quais poderia ser acrescentado também a linguagem. Segundo ele nos relata, muitas vezes suas conclusões seriam contraditórias, mas a somatória destes métodos tornava possível uma ampliação do entendimento de seus objetos de estudo (DANIÉLOU, 1987, p. 307-308) [cf. p. 85 acima].

Ao afrouxar a ideia de que algo deve ser encarado como um conceito, podendo muitas vezes fechar definições num universo limitado, e pensando em suas definições como novas acepções há uma abertura que permite porosidade com outras acepções, enfraquecendo os limites entre sujeito e objeto, entre vários objetos e mesmo entre várias interpretações possíveis, proporcionando - como sugere Rorty - uma ampliação do entendimento, no nosso caso, musical.

Além disso, ao entender as propostas de Daniélou como acepções musicais, proporcionando uma ampliação do entendimento do objeto, que no nosso caso trata-se da música, podemos, como dito na página 19, entender o trabalho de Daniélou também como uma proposta poética, como uma abertura para a criação além de unicamente um estudo fechado sobre teoria, cognição ou filosofia musicais. 
Este entendimento, como veremos logo à frente, foi também o de alguns compositores que estudaram o trabalho de Daniélou e passaram a incorporar suas propostas em seus trabalhos, entendendo seu trabalho não só como dissertativo e descritivo, mas também como propositivo.

Ao fazer uma volta a períodos antigos da história e estudar as tradições musicais da China, Índia e Grécia antiga, fazendo um estudo comparativo entre elas, Daniélou nos propicia um arejamento naquilo que ele considera que contribui para uma espécie de obliteramento do entendimento, muitas vezes presentes no ocidente, que "pretende que tudo, seja o que for, vem dos gregos"275 (DANIÉLOU, 1995, 56).

Curiosamente, e talvez não por coincidência, encontramos em dois textos presentes na edição brasileira do livro A Música Grega de Théodore Reinach (2011), duas afirmações que contribuem para o que estamos delineando aqui.

Começando pelo tradutor da obra, Newton Cunha, no texto $A$ arte e a vida esquecidas, logo na primeira frase afirma: "Aquilo que de melhor a arte e o pensamento ocidentais souberam produzir tem raízes e troncos profundamente implantados na cultura grega" (CUNHA, 2011, p. 25). Pelo menos aqui ele não pretende que tudo vem dos gregos, só "aquilo que de melhor a arte e o pensamento ocidentais souberam produzir". Podemos entrar em discussões dialéticas sobre o que ele quis dizer ou não, o quanto esta frase está ou não delimitada, mas é curioso pelo fato de que há uma ressonância com o que Daniélou afirma, pois se, neste caso, o melhor que o ocidente produziu tem influência grega, de onde viria a influência para aquilo que não é o melhor? Valeria a pena estudar o que não influenciou o que de melhor o ocidente produziu?

Uma segunda afirmação está no texto de Lívio Tragtenberg: Música Antiga Grega, hoje?. Nele podemos verificar uma abordagem semelhante àquela que estamos propondo à obra de Alain Daniélou. Tragtenberg afirma numa metáfora que

a linguagem da criação artística se comporta de forma pendular. Um pêndulo caótico, à maneira de um atrator, com recorrências disformes, mas paralelas. Passado, presente e futuro são apenas conceitos abstratos. Cabe à criação qualificá-los. (TRAGTENBERG, 2011, p. 9)

Dito isso, ele propõe - e aqui também está a forma com que nos propusemos estudar a obra de Alain Daniélou - que o livro de Reinach proporciona "saltar mais de dois mil anos de história da música, ir à fonte e recuperar o fio da meada de questões que dizem respeito ao

${ }^{275}$ pretends that everything whatsoever comes from the Greeks. 
nosso momento atual, às situações estéticas e técnicas que se apresentam hoje em dia" (Idem p 9-10). É aproximadamente desta forma que entendemos os estudos de Daniélou, com a diferença que o salto não se dá apenas no tempo, mas também no espaço e entre culturas distintas, de maneira que se pode não apenas retomar o fio da meada, mas fiar novos e diferentes fios.

Nosso percurso atravessou diversas disciplinas e temas com que pudemos emparelhar o trabalho de Daniélou e encontrar interseções ou produzir contatos. Vimos o trabalho de Daniélou a partir da Filosofia da Música, constatando seu aspecto heterônomo, porém ampliado por sua concentração no som; a partir da Teoria da Música abordamos os aspectos simbólicos e matemáticos de sua obra; e com a Cognição Musical foi possível entender algumas de suas fragilidades e consequências para o estudo da Semântica Musical.

Com relação à Filosofia da Música, embora a proximidade de Daniélou se dê de maneira mais efetiva com o que definimos como Música Especulativa, o estudo da música como espelho do mundo, vimos que seu livro Sémantique Musicale está bastante ligado ao que demarcamos como Especulação Musical, o estudo da música a partir de outras disciplinas.

Com a proximidade da Música Especulativa notamos também a proximidade com o que Burckhardt chama de Arte Sagrada pois

O objetivo último de tal arte não é a evocação de sentimentos, nem a transmissão de impressões; ela é um símbolo e, como tal, bastam-lhe meios simples e primordiais. Não poderia, aliás, ser mais que uma alusão, já que seu objeto real é o inefável. Sua origem é angélica, pois seus modelos refletem realidades supra-formais. Reconstituindo a Criação - a "arte divina" - em parábolas, demonstra a natureza simbólica do mundo e assim liberta o espírito humano de seu apego aos "fatos" toscos e efêmeros. (BURCKHARDT, 2004, p. 20-21)

Trata-se da mesma maneira com que Daniélou entende a música indiana, que evoca determinados climas e ambientes, proporcionando o despertar de ideias e sentimentos, mais do que imita sonoramente objetos, animais ou situações de forma literal.

Com relação à Especulação Musical, vimos que seu livro Sémantique Musicale possui tal abordagem, utilizando elementos da física, fisiologia e cibernética.

Aproximamos sua acepção sobre a música como uma linguagem à maneira como se concebe o ethos grego, mais do que à Doutrina dos Afetos, ou à Expressão dos Sentimentos romântica. Porém vimos que tal aproximação se deve provavelmente a uma questão cultural e religiosa, pois Daniélou aproxima os deuses Shiva e Dioniso como tendo origem no mesmo 
princípio, portanto a semelhança com o ethos tratar-se-ia mais de um paralelismo de concepções similares do que uma filiação.

Com relação à Teoria da Música, abordamos como a acepção de Daniélou incorpora elementos simbólicos presentes em diversas culturas, e que são compartilhadas, desde o princípio, com nossa própria música ocidental. Além disso, observamos o aspecto matemático presente na construção de sua Escala Universal dos Sons, bem como os desdobramentos que esta construção nos proporcionou para a identificação dos limites e diferenças entre tônica e fundamental.

Já a Cognição Musical nos permitiu expor as aparentes fragilidades de sua acepção da semântica musical e, ao mesmo tempo, notar que tais fragilidades encontram-se de algum modo nas próprias características deste campo. No entanto, os caminhos trilhados pela Cognição Musical, embora compartilhem de problemas semelhantes àqueles propostos por Daniélou, não compartilharam de suas hipóteses, justificativas, conclusões e propostas. Entendemos desse modo que sua contribuição neste campo, embora não seja efetiva na resolução de problemas, ajudaria a encontrar novas possibilidades de problematização, pois aparentemente as perguntas continuam ainda semelhantes.

Vale a pena destacar aqui a forma como Daniélou aproxima as diversas tradições musicais clássicas por ele analisadas. Para ele, elas partilham do mesmo princípio acústico: a concepção do espaço sonoro e a forma como se dá a sua divisão por meio da discretização das alturas. Utilizamos abaixo uma possível justificativa desta discretização do espaço sonoro, pelo menos no ocidente.

Trata-se de Boécio que

na introdução de sua obra Institutione arithmetica, o autor romano define um programa educacional para os estudantes das artes liberais no qual deveriam estar presentes as quatro ciências matemáticas: a astronomia, a aritmética, a geometria e a música. Ele chamou a esse conjunto de quadrivium: trata-se do conjunto de disciplinas que deveriam levar o ser humano ao conhecimento das essências imutáveis na natureza. Para o filósofo cristão, as ciências do quadrivium apareciam na seção do estudo dos seres naturais, também chamado de fisiologia ou física. Como estudioso e tradutor dos escritos lógicos de Aristóteles, o autor distinguia a categoria de quantidade em dois gêneros: discreto e contínuo. Na quantidade discreta, a espécie é o número; e a aritmética e a música são as disciplinas matemáticas que lidam com as quantidades discretas, pois a primeira trabalha com o número em si mesmo e a outra, com as relações entre os números (razões e proporções). As outras duas ciências, a geometria e a astronomia, lidam com as quantidades contínuas, as magnitudes geométricas ligadas ao movimento e ao repouso. Suas espécies são a forma imóvel (geometria) ou móvel (astronomia). Uma magnitude pode ser infinitamente dividida, mas a 
unidade, a origem da quantidade discreta, é indivisível. (GUSMÃO, 2010, p. 87-88)

A utilização de diferentes alturas resultantes dessa divisão do espaço sonoro é que diferencia uma cultura da outra. Por este ponto de vista, ele considera os diversos sistemas musicais como não contraditórios ou em oposição e sim como complementares.

Tal complementaridade dos sistemas é que aproximam seus aspectos teóricos, sejam eles matemáticos ou simbólicos e, deste modo, tornam coincidentes suas concepções heterônomas da música. Tal característica determina que a música serve como uma espécie de veículo, apropriada para a transmissão de conhecimentos, ideias e sentimentos. Daniélou parte do princípio de que a música é uma linguagem, e assim como outras artes, foi adotada na Índia como um meio mais efetivo e rápido para a educação ética e moral da população.

Embora afirmando o caráter simbólico da música, vimos com Piana que há uma diferença na maneira como Daniélou entende a relação entre os diferentes intervalos. Mesmo utilizando relações matemáticas para a construção de sua escala, sua referência é sempre a questão auditiva, o som em seu aspecto físico.

Como o próprio Daniélou afirma, ao comentar sobre a interpretação musical que muda determinados intervalos por razões expressivas,

as relações de frequência, que parecem corresponder a estes intervalos expressivos, nos permitem formular certas observações sobre suas características numéricas que, creio eu, permite-nos facilmente, se fizermos as observações coordenadas com os instrumentos adequados, formular uma teoria das escalas musicais baseada sobre nossas reações psicológicas e nossas possibilidades auditivas e mentais de análise das relações, muito mais que nos baseando sobre as particularidades da ressonância das cordas e dos corpos sonoros. $^{276}$ (DANIÉLOU, 1963, p. 211)

Neste ponto ele difere das correntes pitagóricas pois, como aponta Lia Tomás,

para o pitagorismo (século VI a. C.), a escola filosófica na qual segundo a historiografia, ocorreu a primeira tentativa de teorização da linguagem musical, deparamos com um fato, no mínimo, singular: em seus primeiros experimentos, não é a audição que vai ser tomada como base para seus assentamentos, mas sim um tipo de raciocínio lógico. (TOMÁS, 2002, p. 17)

\footnotetext{
${ }^{276}$ Les rapports de fréquences, qui semblent correspondre à ces intervalles expressifs, nous permettent de formuler certaines observations sur leur caractéristiques numériques qui, je le crois, nous permettraient aisément, si nous faisions des observations coordonnées avec des instruments adéquats, de formuler une théorie des échelles musicales basée sur nos réactions psychologiques et nos possibilités auditives et mentales d'analyse des rapports, plutôt qu'en nous basant sur les particularités de la résonance des cordes et des corps sonores.
} 
E dessa forma, como nos mostra Giovanni Piana "as considerações metafísicas vão para segundo plano, a numerologia interessa muito menos do que interessa uma possível análise da constituição interna do som como evento da natureza"277 (PIANA, 2003, p. 29). O que torna o trabalho de Daniélou mais um estudo dos efeitos do som no ser humano, do que um estudo das relações matemáticas aplicadas ao som. Por tal motivo entendemos que sua obra foi estudada por compositores, aplicando de maneira mais ou menos efetiva as indicações propostas por Alain Daniélou.

Entre estes compositores citamos os americanos La Monte Young (1935) e Ben Johnston (1926).

La Monte Young ${ }^{278}$ (1935) é considerado o pai da música minimalista, trabalhou com Andy Warhol e fez parte do grupo Fluxus, do qual participou também Yoko Ono. Dedicou-se à música experimental e de vanguarda, participando de cursos ministrados em Darmstadt por Karlheinz Stockhausen e manteve correspondência com John Cage. Várias de suas composições são conceituais e desafiam as definições tradicionais do que é música. Seu trabalho tem influência do Cantochão, da Música Indiana, do Gagaku e das orquestras de Gamelão da Indonésia. Procura criar com sua esposa Marian Zazeela, artista que trabalha com luz, instalações compostas de som e luz que proporcionam ambiências oníricas ao espectador/ouvinte.

Trabalhou também com música improvisada e jazz e devido ao seu interesse na música asiática tornou-se discípulo do cantor de música clássica indiana Pandit Pran Nath. Considera como sua obra prima a música The Well-Tuned Piano (O Piano Bem-Afinado), em que permuta motivos e improvisações num piano afinado em afinação justa, cujas performances podem durar até seis horas. Esta música é influenciada fortemente pela matemática e pela improvisação da música Hindustani ${ }^{279}$. Suas músicas, além de serem de longa duração, utilizam-se também de notas longas, ou drones ${ }^{280}$.

Seu diálogo com a obra de Alain Daniélou se dá inicialmente com um artigo de Daniélou, The influence of sound phenomena on human consciousness, publicado na revista Psychedelic Review n. 7 de 1966. A respeito deste artigo La Monte Young afirma:

As frequências harmonicamente relacionadas nas quais estou interessado

\footnotetext{
${ }^{277}$ le considerazioni metafisiche regrediscono sullo sfondo, la numerologia interessa assai meno di quanto interessi una possibile analisi della costituzione interna del suono come evento della natura.

${ }^{278}$ Mais informações em $<$ http://www.melafoundation.org $>$

${ }^{279}$ Música praticada no norte da Índia

${ }^{280}$ Pode-se traduzir drone como zumbido ou pedal. As notas tocadas por uma tampura na música indiana, formando uma espécie de base sobre qual o instrumentista improvisa, é chamada de drone.
} 
tem muito a ver com o modo como ouvimos e o modo como muitos sons são estruturados. Estas características comuns reforçam uma a outra. Alain Daniélou assinala em um artigo sobre som na Psychedelic Review \#7 que ele sente que o mecanismo mental nos permite analisar e reconhecer apenas aqueles intervalos musicais que são relacionados harmonicamente. Esta é uma área em que eu planejo trabalhar mais - o que acontece depois que a informação transportada pelo som passa o estágio de recepção no ouvido. É altamente provável, como eu ouço, que o que me faz gostar deste som é mais do que apenas o modo como o ouvido recebe a informação; o cérebro acha este tipo de informação agradável. ${ }^{281}$ (YOUNG; ZAZEELA, 2004, p. 36)

Sua utilização de drones e da afinação justa, bem como sua fascinação por "entrar no som" - as performances de La Monte Young costumam ser longas e num volume alto “forneceu os meios para criar música com a qualidade 'penetrante' descrita por Daniélou isto é, música que poderia interagir diretamente com a mente e o espírito através da psicoacústica e da psicofisiologia”282 (GRIMSHAW, 2011, p. 96).

Por sua vez, Ben Johnston ${ }^{283}$ (1926) é um dos compositores mais empenhados na utilização da afinação justa em instrumentos tradicionais, principalmente os de orquestra, para os quais criou um sistema de notação específico. Foi professor de teoria e composição de 1951 a 1984 na Universidade de Illinois na Escola de Música de Urbana-Champaign, tendo aí se aposentado.

Compôs operas, teatro-musical, música para dança e obras para orquestra e para grupos de câmara, além de peças para tape, piano, voz solo e coral tendo trabalhado também com música indeterminada. Foi aluno de Harry Partch, Darius Milhaud e John Cage.

A respeito do uso da afinação justa, ele estende os limites do uso dos números primos para formar escalas muitas vezes até múltiplos do parcial 31, como no seu Quarteto de Cordas $\mathrm{n}^{\circ}$ 9. Para termos uma ideia, Daniélou defende o uso no máximo dos múltiplos do parcial 5, este é o seu limite, por razões espirituais e teológicas.

Sobre este uso estendido da escala justa, ele relata que "ao contrário da música de Partch $^{284}$, eu não desejava desacreditar ou substituir a tradição musical europeia, mas apenas

${ }^{281}$ The harmonically related frequencies I'm interested in have so much to do with the way we hear and the way so many sounds are structured. These common characteristics reinforce each other. Alain Daniélou points out in an article on sound in the Psychedelic Review \#7 that he feels the mental mechanism permits us to analyze and recognize only those musical intervals which are harmonically related. This is an area in which I plan to do more work - what happens after the information carried by the sound passes the reception stage at the ear. It is highly likely, as I hear it, that what makes me like this sound is more than just the way the ear receives information; the brain finds this kind of information congenial.

${ }^{282}$ provided the means for creating music with the 'penetrating' quality Daniélou described - that is, music that could interface directly with the mind and spirit through psychoacoustics and psychophysiology.

${ }^{283}$ Mais informações em $<$ http://newdissonance.com $>$

${ }^{284}$ Harry Partch, compositor americano que também trabalhava com afinações alternativas e principalmente com a afinação justa, para isso construía instrumentos especiais para suas músicas. 
livrá-la de suas próprias complicações do temperamento igual para deixá-la desenvolver-se em sua própria direção" ${ }^{285}$ (JOHNSTON, 2006, p. 165). Esta posição, no entanto, o aproximou das tradições musicais não ocidentais como a Chinesa, a Indiana, a Árabe e a Grega antiga, como ele mesmo relata: "Eu explorei estas relações primeiro nos escritos de Alain Daniélou, mas elas eram para mim uma questão secundária e não uma preocupação primordial. Estes escritos foram de grande ajuda para mim na busca de uma teoria musical mais generalizada"286 (Ibidem).

Além disso Ben Johnston faz da música praticamente uma profissão de fé:

J. S. Bach professou dedicar todas suas composições para a glória maior de Deus. Traduzindo isso numa linguagem mais contemporânea, ele via a função fundamental da música como uma ajuda ao crescimento espiritual. Eu compartilho desta convicção. Parece-me que a arte de alguém não é ou não deveria ser um meio para glorificar a própria vaidade egoísta, mas sim um auxílio ao autoconhecimento na busca da evolução espiritual da vida interior em um eu maior não mais egoísta. Eu penso que isto é fundamental para todas as religiões, não importa qual tradição. Parece-me, [...] que a afinação justa é um principio de valor inestimável para tal fim. ${ }^{287}$ (Ibidem)

Por fim, concluímos que o trabalho de Daniélou pode contribuir tanto para o entendimento de nossa própria música como para a criação de novas possibilidades musicais, e esta contribuição nos parece ser devida à sua crítica ao sistema temperado e à sua apologia às afinações naturais, tanto no que diz respeito aos seus aspectos metafísicos e simbólicos, como vemos acima nas falas de La Monte Young e Ben Johnston, como também em seu aspecto sonoro, como os mesmos compositores se referem e como Piana nos informa a respeito da metafísica cair para segundo plano devido à opção de Daniélou pelo som.

Pensamos que uma contribuição seja a diferenciação que estabelecemos acima, ao falar da Escala Universal dos Sons de Alain Daniélou, entre tônica e fundamental. Apesar de tais termos serem utilizados na música tonal há tempos, a interpretação que fazemos, possibilitada pelos estudos de Alain Daniélou, pode proporcionar uma nova abordagem na organização das alturas.

\footnotetext{
${ }^{285}$ unlike Partch's music, I had no wish to discredit or to replace European musical tradition, but only to free it from its own entanglements in equal temperament in order to let it develop further in its own direction.

${ }^{286}$ I first explored these relationships in the writings of Alain Daniélou, but they were to me a side issue and not a primary concern. These writings were of great aid to me in seeking a more generalized theory of music.

${ }^{287}$ J. S. Bach professed to dedicate all his compositions to the greater glory of God. To translate this into more contemporary language, he saw the fundamental function of music as an aid to spiritual growth. I share this conviction. It seems to me that one's art is not or should not be a means to glorify one's egotistic vainglory, but rather an aid to self-knowledge in the pursuit of the spiritual evolution of one's interior life into a greater and no longer egotistical self. I think this is fundamental to all religions of no matter what tradition. It seems to me, [...] that just intonation is an invaluable principle in such aim.
} 
No temperamento igual, devido à igualdade de relação entre todas as notas ou alturas, não podemos determinar com maior precisão as diferenças entre tônica e fundamental, carregando em seu bojo certa ambiguidade. Embora se utilize da série harmônica e do princípio da ressonância para justificar determinada tônica de uma escala ou fundamental de um acorde, estas relações, por participarem do temperamento igual, não determinam de maneira inequívoca tais tônicas ou fundamentais, por mais aproximadas que sejam dos intervalos justos determinados pela série harmônica.

O dodecafonismo se desenvolveu a partir da ideia de que qualquer nota a qualquer momento pode se tornar uma tônica ou uma fundamental, e mesmo no tonalismo ou no modalismo, ao utilizarmos o temperamento igual estaremos sempre dentro da coleção de doze notas possíveis determinadas pala escala cromática.

Esta propriedade da escala cromática sempre nos sugere uma organização das notas em duas dimensões simulando três, um plano em duas dimensões movendo-se no tempo uma organização relativista baseada mais na nota que no som.

Por sua vez, a escala gerada por intervalos justos proporciona novas fundamentais a cada nova relação entre as frequências. Tais fundamentais muitas vezes estão implícitas, como no caso da Escala Universal dos Sons de Alain Daniélou. Mesmo que mantivermos a mesma tônica, ao acrescentarmos novos sons ou retirarmos outros desta coleção, há a possibilidade de mudança na fundamental mudando todo o quadro de relações entre os sons. Consideramos que esta propriedade da afinação justa ou natural, que trás como consequência uma mobilidade de fundamentais, diferencia-se do relativismo do temperamento igual, pois possibilita uma organização espacial tridimensional dos sons movendo-se no tempo, um tipo de perspectivismo, que pode tornar-se campo fértil para a criação. 


\section{REFERÊNCIAS BIBLIOGRÁFICAS}

ALVES, Rubem. Filosofia da ciência: introdução ao jogo e suas regras. São Paulo: Loyola, 2000 .

ANTUNES, Jorge. O Silêncio. Opus: Revista da Associação Nacional de Pesquisa e PósGraduação em Música - ANPPOM. Rio de Janeiro, v.6, 1999. Disponível em:

$<$ http://www.anppom.com.br/opus/opus6/antunes.htm>. Acesso em: 12 nov. 2010.

AUGUSTINI, S. Aurelii [389 a. D]. De Musica Libri Sex. fac-simile: s.l., s.d.

Disponível em: $<$ http://www.documentacatholicaomnia.eu/04z/z_0354-

0430 Augustinus De Musica_Libri Sex MLT.pdf.html>. Acesso em: 2 jun. 2013 às $6 \mathrm{~h} 52$.

BENATON, Jocelyn. O que é cibernética. São Paulo: Nova Cultural / Brasiliense, 1986. (Primeiros Passos; 90)

BENEITO, Pablo. Considerações sobre o simbolismo. In: LEITE, Sylvia Virgínia Andrade. O Simbolismo dos padrões geométricos da arte islâmica. Cotia (SP): Ateliê Editorial, 2007, p. $17-28$

BARTEL, Dietrich. Musica Poetica: musical-rhetorical figures in German Baroque music. Lincoln (Nebraska): University of Nebraska Press, 1998.

BERENDT, Joachim-Ernst. Nada Brahma: a música e o universo da consciência. São Paulo: Cultrix, 1997.

BLANNING, Tim. O triunfo da música: a ascensão dos compositores, dos músicos e de sua arte. São Paulo: Companhia das letras, 2011.

BOETHIUS. Fundamentals of music. Translated with Introduction and Notes by Calvin M. Bower. Edited by Claude V. Palisca. New Haven: Yale University Press, 1989.

BOFF, Leonardo. Ética e moral: a busca dos fundamentos. Petrópolis (RJ): Vozes, 2003. $3^{\text {a }}$ ed.

BOWER, Calvin M. The transmission of ancient music theory into the Middle Ages. In: CHRISTENSEN, Thomas (Ed.). The Cambridge history of Western Music Theory. 
Cambridge (UK): Cambridge University Press, 2002 (reprinted 2004) p. 136-167.

BROLEZZI, Antonio Carlos. A tensão entre o discreto e o contínuo na história da matemática e no ensino de matemática. São Paulo, 1996. 84 f. Tese (Doutorado em Educação) - Faculdade de Educação (FE), Universidade de São Paulo.

BURCKHARDT, Titus. A arte sagrada no oriente e no ocidente: princípios e métodos. São Paulo: Attar, 2004.

CHRISTENSEN, Thomas. Introduction. In: (Ed.). The Cambridge history of

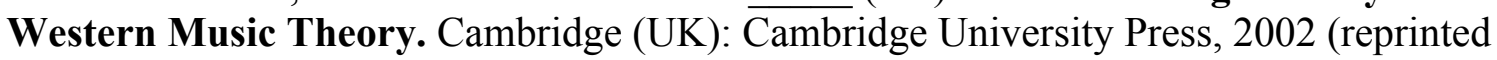
2004) p. 1-23.

CINTRA, Celso L. A. Entre a Música Especulativa e a Especulação Musical: o trabalho de Alain Daniélou. In: JORNADA ACADÊMICA DISCENTE - PPGMUS/USP, 1, 2012, São Paulo. Anais... São Paulo: PPGMUS/USP. Disponível em:

$<$ http://www.pos.eca.usp.br/sites/default/files/jornada discente/ppgmus/celso cintramus_etno.pdf $>$. Acesso em: 21 out. 2012.

Tônica x Fundamental: a escala universal dos sons de Alain Daniélou e sua relação com a série harmônica. In: XXI Congresso da ANPPOM - Associação Nacional de Pesquisa e Pós-Graduação em Música 2011, Uberlândia. Anais... Uberlândia: ANPPOM, 2011. p. 1673-1679. Disponível em:

$<$ http://www.anppom.com.br/anais/anaiscongresso_anppom 2011/ANAIS_do_CONGRESS O_ANPPON_2011.pdf $>$.

CLOAREC, Jacques. Alain Daniélou. A brief biography. In: DANIÉLOU, Alain. Sacred music its origins, powers and future: traditional music in today's world. Varanasi (Índia): Indica, 2003. p. 207-11.

COTTE, Roger J. V. Música e simbolismo: Ressonâncias cósmicas dos instrumentos e das obras. São Paulo: Cultrix, 1991. $2^{\mathrm{a}}$ ed.

CUNHA, Newton. A arte e a vida esquecidas. In: REINACH, Théodore. A música grega. Trad. Newton Cunha. São Paulo: Perspectiva, 2011. (Signos Música; 12). p. 25-28.

DAHLHAUS, Carl. Estética Musical. Lisboa: Edições 70, 2003.

DANIÉLOU, Alain. Shiva et Dionysos: la religion de la nature et de l'Eros. De la préhistoire à l'avenir. Domont (France): Fayard, 2009. (Documents Spirituels) 
Aesthetics and Indian Music. Sangeet Natak, New Delhi (India): Sangeet Natak Akademi - The National Academy of Music, Dance and Drama for India, v. XLII, n. 1, p. 86$90,2008 \mathrm{a}$

. The traditional arts and their place in the culture of India. Sangeet Natak, New Delhi (India): Sangeet Natak Akademi - The National Academy of Music, Dance and Drama for India, v. XLII, n. 1, p. 91-103, 2008b

La théorie métaphysique du verbe et son application dans le langage et la musique. Publicado por Murilo Cardoso de Castro em 21 dez. 2007. Disponível em: $<$ http://sophia.free-h.net/spip.php?article92>. Acesso em: 02 mar. 2011.

Origines et pouvoirs de la musique. 2e. ed. Pondicherry (India): Kailash, 2005a. (Les cahiers du mleccha)

. L'Agression Harmonique. In: Origines et pouvoirs de la musique. $2 \mathrm{e}$. ed. Pondicherry (India): Kailash, 2005b. (Les cahiers du mleccha)

. Traité de Musicologie Comparée. Paris: Hermann, 2004. (nouveau tirage)

Sacred music its origins, powers and future: traditional music in today's world. Varanasi (India): Indica, 2003a

The origins of sacred music. In: Sacred music its origins, powers and future: traditional music in today's world. Varanasi (India): Indica, 2003b. p. 15-26. $404 \mathrm{p}$.

. The rāga-s of northern Indian music. New Delhi: Mushiram Manoharlal, 2003c.

Music and the power of sound: the influence of tuning and interval on consciousness. Rochester, Vermont: Inner traditions International, 1995.

. Shiva e Dioniso: a religião da natureza e do Eros. São Paulo: Martins Fontes, 1989. Original francês.

The way to the labyrinth. Trad. Marie-Claire Cournand. New York: New Directions Book, 1987. Original francês. 
. Sémantique Musicale: essai de psycho-physiologie auditive. 2 ed. Paris: Hermann, 1993 (nouveau tirage). . Paris: Hermann, 1967.

. Introduction to the study of musical scales. New Delhi (India): Oriental Books Reprint, 1979.

. The influence of sound phenomena on human consciousness. Psychedelic Review, New York, v. 7, p. 20-26, 1966.

Les éléments de formation des échelles extérieurs a la résonance: les déformations expressives. In: WEBER, Edith (Org.). La résonance dans les échelles musicales. Paris: Centre National de la recherche scientifique - Paris VII, 1963. p. 207-214.

DART, Thurston. Interpretação da música. São Paulo: Martins Fontes, 2002.

DUFFIN, Ross W. How the equal temperament ruined the harmony (and why you should care). New York: W. W. Norton \& Company, 2007.

ECO, Umberto. O nome da rosa. Rio de Janeiro: Nova Fronteira, 1983.

ESCAL, Françoise. Introduction. In: DANIÉLOU, Alain. Sémantique Musicale: Essai de psycho-physiologie auditive. (nouveau tirage) 2ed. Paris: Hermann, 1993. p. 1-12.

FERRAND, Françoise. Os primeiros cânticos da Igreja. In: MASSIN, Jean; MASSIN, Brigitte. História da Música Ocidental. Trad. do francês Maria Teresa Resende Costa, Carlos Sussekind, Angela Ramalho Viana. Rio de Janeiro: Nova Fronteira, 1997. p. 135-139.

FUBINI, Enrico. Individualidade ou universalidade da linguagem musical. Trad. do italiano Antônio Flávio Pierucci. Novos Estudos - CEBRAP, São Paulo, n.60, p. 109-118, 2001 a.

La estética musical desde la Antigüedad hasta el siglo XX. Madrid: Alianza Editorial, 2001b (segunda reimpresión).

Estetica della musica. Bologna: Il Mulino, 1996 (Lessico dell'estetica v. 3). 
GABIN, Jean-Louis. L'Hindouisme traditionnel et l'interprétation d'Alain Daniélou. Paris: Éditions du Cerf, 2010.

GAÍNZA, J. Javier Goldáraz. Afinación y temperamento en la música occidental. Madrid: Alianza Editorial, 1992.

GADAMER, Hans-Georg. Elogio da Teoria. Lisboa: Edições 70, 2001.

Verdade e Método: traços fundamentais de uma hermenêutica filosófica. $3^{\mathrm{a}}$ ed. Petrópolis: Vozes, 1997.

GARDNER, Howard. A nova ciência da mente. São Paulo: Edusp, 2003.

GHIRALDELLI JUNIOR, Paulo. História essencial da filosofia. São Paulo: Universo dos Livros, 2010. 112p. (vol. 3)

Como estudar filosofia. Disponível em:

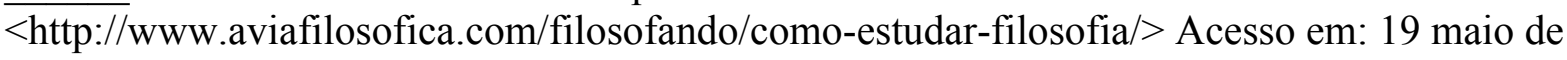
2013.

GOBRY, Ivan. Vocabulário grego da filosofia. São Paulo: Martins Fontes, 2007.

GODWIN, Joscelyn. Harmonies of Heaven and Earth: mysticism in music from antiquity to the avant-garde. 5ed. Rochester (Vermont): Inner Traditions International, 1995.

Speculative music: the numbers behind the notes. In: PAYNTER, John; HOWELL, Tim; ORTON, Richard; SEYMOUR, Peter. Companion to contemporary musical thought. London: Routledge, 1992. Vol. 1. p. 256-71.

GOLDSCHMIDT, Victor. Tempo histórico e tempo lógico na interpretação dos sistemas filosóficos. In: . A religião de Platão. São Paulo: Difel, 1963 p. 139-147.

GOSWAMI, Amit. A janela visionária: um guia para iluminação por um físico quântico. São Paulo: Cultrix, 2003. 279p.

GOUK, Penelope. The role of harmonics in the scientific revolution. In: CHRISTENSEN, 
Thomas (Ed.). The Cambridge history of Western Music Theory. Cambridge (UK):

Cambridge University Press, 2002 (reprinted 2004) p. 223-245.

GOUNOD, Charles. L'Allaitement musical. Le Ménestrel, Paris, n. 8, 48 année p. 57-59, 1882. Disponível em:

$<$ http://gallica.bnf.fr/ark:/12148/bpt6k56156737/f1.image.r=gounod.langPT $>$ Acesso em 1 jun 2013 às $22 \mathrm{~h} 13$.

GRIMSHAW, Jeremy Neal. Draw a straight line and follow it: the music and mysticism of La Monte Young. New York: Oxford University Press, 2011.

GROSSATO, Alessandro (Org.) La corrispondenza fra Alain Daniélou e René Guénon: 1947 - 1950. Firenze: Leo S. Olschki Editore, 2002. (Orientalia Venetiana XIII)

GUÉNON, René. Remarques sur la notation mathématique. In: . Mélanges. Paris:

Gallimard, 1976. p. 78-101.

Orient et Occident. Québec: Les Classiques des Sciences Sociales, 2012.

Disponível em:

$<$ http://classiques.uqac.ca/classiques/guenon_rene/orient_et_occident/orient_et_occident.pdf $>$ Acesso em 1 de junho de 2013 às $22 \mathrm{~h} 32$

GUSMÃO, Cynthia Sampaio de. A harmônica na Antiguidade grega. São Paulo, 2010. 102 f. Dissertação (Mestrado em Filosofia) - Faculdade de Filosofia, Letras e Ciências Humanas (FFLCH), Universidade de São Paulo.

HANSLICK, Eduard. Do belo musical: um contributo para a revisão da estética da arte dos sons. Trad. Artur Morão. Covilhã (Portugal): LusoSofia, 2011. Original alemão. (Textos clássicos de fillosofia) versão em pdf disponível em $<$ http://www.lusosofia.net $>$.

HARNONCOURT, Nikolaus. O discurso dos sons: caminhos para uma nova compreensão musical. Trad. Marcelo Fagerland. Rio de Janeiro: Jorge Zahar, 1998. Original alemão.

HERLINGER, Jan. Medieval Canonics. In: CHRISTENSEN, Thomas (Ed.). The Cambridge history of Western Music Theory. Cambridge (UK): Cambridge University Press, 2002 (reprinted 2004) p. 168-192.

HUXLEY, Julian. Psychometabolism. The psychedelic music review. Cambridge, Massachusetts: s. e., Vol. 1. No 2, Fall, p. 183-204, 1963. 
ILARI, Beatriz Senoi. Cognição musical: abordagens tradicionais, direções futuras. In: ; ARAÚJO, Rosane Cardoso (Orgs.). Mentes em Música. Curitiba: Ed. UFPR, 2010.

p. 11-33. (Série Pesquisa, n. 165)

JOHNSTON, Ben. "Maximum clarity" and others writings on music. Edited by Bob Gilmore. Champaign (IL): University of Illinois press, 2006.

JOOS, Martin. Acoustic Phonetics. Language. Washington, DC: Linguistic Society of America, Vol. 24. No 2, Language Monograph No. 23: Acoustic Phonetics. Apr.-Jun., p. 5$131+133-136,1948$. Stable URL: <http://www.jstor.org/stable/522229>. Access Ed: $02 / 06 / 201302: 11$

JUNG, Carl G. Chegando ao inconsciente. In: JUNG, Carl G. et al.; JUNG, Carl G. (Org.). O homem e seus símbolos. Trad. Maria Lúcia Pinho. Rio de Janeiro: Nova Fronteira, 2008. Original inglês. p. 14-131. $2^{\mathrm{a}}$ ed. especial

KANNO, Mieko. Thoughts on how to play in tune: pitch and intonation. Contemporary music review. Microtones and microtonalities. Oxfordshire (UK): Routledge; Taylor \& Francis, Vol. 22. Parts 1+2, March/ June, p. 35-52, 2003.

KERMAN, Joseph. Musicologia. São Paulo: Martins Fontes, 1987.

KUHN, Thomas S. A estrutura das revoluções científicas. São Paulo: Perspectiva, 2003.

LANGER, Susanne K. Filosofia em nova chave. São Paulo: Perspectiva, 1971.

LAOZI. Dao de Jing (Tao Te King). Org. e trad. do chinês Mario Bruno Sproviero. São Paulo: Hedra, 2007. (Edição bilíngue)

LAWLOR, Robert. Geometria sagrada: filosofia e prática. Madrid: Del Prado, 1996. (Mitos Deuses Mistérios)

LEIBNIZ, Gottfried Wilhelm von. Duas Cartas sobre Música (Tradução e apresentação de Juvenal Savian Filho). Discurso - Revista do Departamento de Filosofia da USP, São Paulo: Universidade de São Paulo, Departamento de Filosofia, FFLCH, no 37 (música e filosofia), p. 103-112, 2007. 
LusoSofia, s.d.. Original francês. (Textos clássicos de filosofia) versão em pdf disponível em

$<$ http://www.lusosofia.net $>$.

LEITE, Sylvia Virgínia Andrade. Simbolismo, o elo perdido: estudo da ciência das letras no sufismo. São Paulo, 2009. 191 f. Tese (Doutorado em Filosofia) - Faculdade de Filosofia, Letras e Ciências Humanas (FFLCH), Universidade de São Paulo.

. O Simbolismo dos padrões geométricos da arte islâmica. Cotia (SP): Ateliê Editorial, 2007.

LEVITIN, Daniel J. A música no seu cérebro: a ciência de uma obsessão humana. Rio de Janeiro: Civilização Brasileira, 2010.

Em busca da mente musical. In: ILARI, Beatriz (Org.). Em busca da mente musical: ensaios sobre os processos cognitivos em música - da percepção à produção. Curitiba: Editora da Universidade Federal do Paraná, 2006.

LIPPMAN, Edward. The place of aesthetics in theoretical treatises on music. In: HATCH, C., BERNSTEIN, D. W. (Ed.) Music theory and the exploration of the past. Chicago: Chicago University Press, 1993.

LUCAS, Mônica. Retórica e estética no século XVIII. ArtCultura: revista de história, cultura e arte. Uberlândia (MG): Universidade Federal de Uberlândia, Instituto de História, v. 9, n. 14, p. 223-234, 2007.

MARCK, Henry J. Elementary Thinking and the Classification of Behavior. Science, American Association for the Advancement of Science, v.135, No 3498 p. 75-87, 1962. Stable URL: < http://www.jstor.org/stable/1707549>. Accessed: 02/06/2013 00:39

MENEZES, Flo. A acústica musical em palavras e sons. Cotia (SP): Ateliê Editorial, 2003.

Música Eletroacústica: história e estéticas. São Paulo: Edusp, 1996.

MERRIAN, Alan P. Ethnomusicology Revisited. Ethnomusicology, University of Illinois Press on behalf of Society for Ethnomusicology, v.13, No 2 p. 213-29, 1969. Stable URL: http://www.jstor.org/stable/850146 Accessed: 02/06/2010 08:57

The anthropology of music. Illinois: Northwestern University Press, 1964. 
MEYER, Leonard B. Un universo de universales. Trad. do inglês de Ramón Pelinski. In: CRUCES, Francisco et al. (Ed.). Las Culturas Musicales: lecturas de etnomusicología. Madrid: Editorial Trotta, 2001. p. 233-259.

NASR, Hossein Seyyed. Prefácio à edição francesa. In: BURCKHARDT, Titus. A arte sagrada no oriente e no ocidente: princípios e métodos. São Paulo: Attar, 2004. p. 11-14.

NATTIEZ, Jean-Jacques. Etnomusicologia e significações musicais. Trad. do francês de Silvana Zilli Bomskov. Per Musi - Revista acadêmica de música, Belo Horizonte, n. 10, p. 5-30, 2004.

NEUBAUER, John. The emancipation of music from language: departure from mimeses in Eighteenth-Century Aesthetics. Michigan: Yale University Press, 1986.

PIANA, Giovanni. La scala universale dei suoni di Daniélou. Versão digital 2003 em pdf. Disponível em: $<$ http://filosofia.dipafilo.unimi.it/piana/index.php/filosofia-della-musica/106la-scala-universale-dei-suoni-di-danielou>. Acesso em: 25 mar. 2011. 51p.

A filosofia da música. Bauru, SP: EDUSC, 2001.

PLATÃO. Timeu-Crítias. Trad. do grego, introdução e notas Rodolfo Lopes. Coimbra: Centro de Estudos Clássicos e Humanísticos (CECH) / Classica Digitalia - Vniversitatis Conimbrigensis (Edição Digital), 2011.

A República. 9 ed. Trad. Maria Helena da Rocha Pereira. Lisboa: Fundação Calouste Gulbenkian, 2001.

REINACH, Théodore. A música grega. Trad. Newton Cunha. São Paulo: Perspectiva, 2011. (Signos Música; 12).

RIVERS-MOORE, Daniel. Editor's Note. In: DANIÉLOU, Alain. Music and the power of sound: the influence of tuning and interval on consciousness. Rochester, Vermont: Inner traditions International, 1995. p. xiii.

RIZEK, Ricardo. A teoria da harmonia em Platão: um estudo sobre a identidade da música ocidental. São Paulo, 2003. 130 f. Dissertação (Mestrado em Artes) - Escola de Comunicações e Artes, Universidade de São Paulo. 
RODRIGUES, André Figueiredo. Como elaborar referência bibliográfica. 7 ed. São Paulo: Humanitas, 2008. (Metodologias, 1)

RODRIGUES, André Figueiredo. Como elaborar citações e notas de rodapé. 4 ed.São Paulo: Humanitas, 2007. (Metodologias, 2)

RODRIGUES, André Figueiredo. Como elaborar e apresentar monografias. 3 ed. Atualizada. São Paulo: Humanitas, 2008. (Metodologias, 3)

ROEDERER, Juan G. Introdução à física e à psicofísica da música. Trad. Alberto Luis da Cunha. São Paulo: Edusp, 1998. Original Inglês

RORTY, Richard. Gadamer e sua utopia. Trad. Paulo Ghiraldelli Júnior. Centro de Estudos em Filosofia Americana-CEFA, 2008. Disponível em:

$<$ http://ghiraldelli.files.wordpress.com/2008/07/rorty_gadamer.pdf $>$ Acesso em: 20 jun. 2011. $7 \mathrm{p}$.

SANTOS, Boaventura de Souza. Um Discurso Sobre as Ciências. São Paulo: Cortez, 2009.

SAVIAN FILHO, Juvenal. Tradução e apresentação. In: LEIBNIZ, Gottfried Wilhelm von. Duas Cartas sobre Música (Tradução e apresentação de Juvenal Savian Filho). Discurso Revista do Departamento de Filosofia da USP, São Paulo: Universidade de São Paulo, Departamento de Filosofia, FFLCH, no 37 (música e filosofia), p. 103-112, 2007.

SCHOENBERG, Arnold. Harmonia. Trad. Marden Maluf. São Paulo: Unesp, 2001.

. Fundamentos da composição Musical. Trad. Eduardo Seincman. São Paulo: Edusp, 1991. (Coleção Ponta; v. 3).

SCHUON, Frithjof. O esoterismo como princípio e como caminho. São Paulo: Pensamento, 1985.

SILVA, Angela Maria; PINHEIRO, Maria Salete de Freitas; FRANÇA, Maira Nani. Guia para normalização de trabalhos técnico-científicos: projetos de pesquisa, trabalhos acadêmicos, dissertações e teses. 5. ed. revisada e atualizada ( $3^{\mathrm{a}}$ reimpressão) UberlândiaMG: Edufu, 2009.

SIMÕES, Carlota; FERNANDES, João. Astrologia e Astronomia: Uma Conversa Entre as Duas. Millenium - Revista do Instituto Politécnico de Viseu, Viseu (PT): Instituto 
Politécnico de Viseu, n ${ }^{\circ} 19$, Junho de 2000. Revista Online. Disponível em:

$<$ http://www.ipv.pt/millenium/19_ect3.htm>. Acesso em 05 jun. 2013.

SLOBODA, John A. A mente musical: psicologia cognitiva da música. Trad. Beatriz Ilari e Rodolfo Ilari. Londrina: Eduel, 2008. Original inglês.

STOCKHAUSEN, Karlheinz. A Unidade do Tempo Musical (1961) In: MENEZES, Flo (Org.) Música Eletroacústica: história e estéticas. São Paulo: Edusp, 1996. p. 141-9.

TEMER, Ana Carolina Rocha Pessoa; NERY, Vanda Cunha Albieri. Para entender as teorias da comunicação. $2^{\mathrm{a}}$ ed. revista e atualizada. Uberlândia (MG): Edufu, 2012.

TOMÁS, Lia. Música e filosofia: estética musical. São Paulo: Irmãos Vitale, 2005. (Conexões Musicais)

. Ouvir o lógos: música e filosofia. São Paulo: Unesp, 2002.

TRAGTENBERG, Lívio. Música Grega Antiga, hoje? In: REINACH, Théodore. A música grega. Trad. Newton Cunha. São Paulo: Perspectiva, 2011. (Signos Música; 12). p. 9-23.

VATTIMO, Gianni. A estrutura das revoluções artísticas. In: O fim da modernidade: niilismo e hermenêutica na cultura pós-moderna. São Paulo: Martins Fontes, 2002.

VIDEIRA, Mário. O romantismo e o belo musical. São Paulo: Unesp, 2006.

WAGNER, Richard. A arte e a revolução. Lisboa: Antígona, 1990.

WEBER, Max. Os fundamentos racionais e sociológicos da música. Trad., introdução e notas de Leopoldo Waizbort e prefácio de Gabriel Cohn. São Paulo: Edusp, 1995. (Clássicos, 1)

WIENER, Norbert. Cybernetics: or control and communication in the animal and the machine. $2^{\mathrm{a}}$ ed. Massachussets: M.I.T. Press, 1962.

WINCKEL, Fritz. Vues nouvelles sur le monde des sons. Trad. A. Moles e J. Lequeux. Original alemão 1952. Paris: Dunod, 1960. 
WISNIK, José Miguel. O Som e o Sentido: uma outra história das músicas. São Paulo: Companhia das Letras, 1989.

XENAKIS, Iannis. Formalized music. Bloomington: Indiana University, 1971.

YOUNG, La Monte; ZAZEELA, Marian. Selected Writings. ubu.com: ubuclassics, 2004. Disponível em $<$ http://www.ubu.com/historical/young/index.html $>$

ZAMPRONHA, Edson Sekeff. Onde está a música?. ARTEunesp, São Paulo, v.12, p. 11533, 1996. 